$$
\begin{array}{r}
\text { Pontifícia } \\
U_{\text {niversidade }} C_{\text {datólica }} \\
\text { Do dio Janeiro }
\end{array}
$$

VANIA MENEZES PEREIRA DA SILVA

\title{
SISTEMA DE ESGOTO NOS QUARTÉIS DA MARINHA DO BRASIL: proposta de modernização dos Complexos Navais
}

\section{Dissertação de Mestrado}

\begin{abstract}
Dissertação apresentada ao Programa de Pós-Graduação em Engenharia Urbana e Ambiental da PUC-Rio como requisito parcial para obtenção do título de Mestre em Engenharia Urbana e Ambiental (opção Profissional).
\end{abstract}

Orientador: Prof. Celso Romanel Co-orientador: Prof. Ernani de Souza Costa 


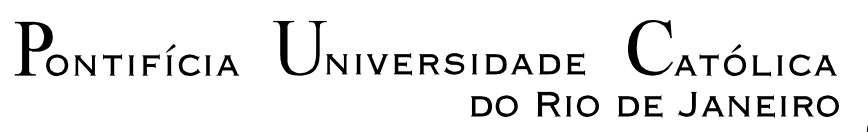

VANIA MENEZES PEREIRA DA SILVA

\section{SISTEMA DE ESGOTO NOS QUARTÉIS DA MARINHA DO BRASIL: proposta de modernização dos Complexos Navais}

Dissertação apresentada como requisito parcial para obtenção do título de Mestre em Engenharia Urbana e Ambiental (opção profissional) pelo Programa de PósGraduação em Engenharia Urbana e Ambiental da PUC-Rio. Aprovada pela Comissão Examinadora abaixo assinada.

Prof. Celso Romanel

Presidente / Orientador

Departamento de Engenharia Civil - PUC-Rio

Prof. Ernani de Souza Costa

Co-Orientador

PUC-Rio

Prof. Paulo Luiz da Fonseca

Prefeitura da Cidade do Rio de Janeiro

Prof. Eduardo Pacheco Jordão

UFRJ

Prof. Márcio da Silveira Carvalho Coordenador Setorial de Pós-Graduação do Centro Técnico Científico - PUC-Rio

Rio de Janeiro, 02 de fevereiro de 2016. 
Todos os direitos reservados. É proibida a reprodução total ou parcial do trabalho sem autorização da universidade, da autora e do orientador.

\section{Vania Menezes Pereira da Silva}

Graduou-se em Engenharia Civil em 1990, pela Universidade Veiga de Almeida. Graduou-se em Direito em 2002, pela Universidade do Estado do Rio de Janeiro (UNIRIO). Possui PósGraduação lato sensu em Direito Público pela Escola de Magistratura do Estado do Rio de Janeiro (EMERJ), concluído em 2011. Lecionou Direito Processual Penal no curso preparatório Proprium Militari no ano de 2012. Exerce a função de Assessora de Coordenação do no Grupo de Gerenciamento do Programa de Construção de Submarinos da Diretoria de Obras Civis da Marinha.

Ficha Catalográfica

Silva, Vania Menezes Pereira

Sistema de esgoto nos quartéis da Marinha do Brasil: proposta de modernização dos Complexos Navais / Vania Menezes Pereira da Silva; orientador: Celso Romanel; coorientador: Ernani de Souza Costa - 2016.

161 f. : il. (color.) ; $30 \mathrm{~cm}$

Dissertação (mestrado) - Pontifícia Universidade Católica do Rio de Janeiro, Departamento de Engenharia Civil, Programa de Pós-Graduação em Engenharia Urbana e Ambiental, 2016.

\section{Inclui bibliografia}

1. Engenharia civil - Teses. 2. Meio Ambiente. 3. Sistema de esgoto. 4. Sistema de esgoto. 5. Licenciamento ambiental. 6. Desempenho ambiental. 7. Marinha do Brasil. I. Romanel, Celso. II. Costa, Ernani. III. Pontifícia Universidade Católica do Rio de Janeiro. Departamento de Engenharia Civil. IV. Título. 
À minha amada Mãe,

Pela presença e apoio incondicional em todos os momentos da vida. 


\section{Agradecimentos}

Sempre presente em minha vida, porque me deu a própria dádiva de viver, agradeço a Deus, o criador de todos os meus pensamentos e inspirações.

A minha amada família, meu porto seguro onde atraco sempre que se faz necessário efetuar o abastecimento de minha alma e de meu coração, pessoas que me proporcionam a estabilidade para caminhar em frente diante das dificuldades e me fazem lembrar o verdadeiro sentido da vida.

A minha grande amiga e sempre presente Érica Barbosa Torres, pela simples presença de sua luz em meu caminho.

Aos meus colegas de trabalho, que me proporcionaram o acesso aos dados técnicos que subsidiaram muitas das soluções e análises, em especial o Engenheiro Júlio e o Arquiteto Pellegrino, profissionais competentes e experientes, além de serem pessoas que sabem fazer do ambiente de trabalho um ambiente de paz e tranquilidade.

Aos professores do Mestrado Profissional em Engenharia Urbana e Ambiental, que lograram êxito em transmitir os seus conhecimentos e experiências com empenho e notável satisfação.

Ao Professor Ernani Costa, pela gentileza em depositar confiança no tema apresentado, pela disponibilidade de sua biblioteca e de seu tempo, bem como pelo apoio integral durante a pesquisa.

A todos os meus colegas do curso de mestrado, pela excelente convivência e troca de experiências, pelo espírito cooperativo e pela amizade que se firmou. 


\section{Resumo}

Silva, Vania Menezes Pereira da; Romanel, Celso (Orientador); Costa, Ernani de Souza (Co-orientador). Sistema de Esgoto nos quartéis da Marinha do Brasil: proposta de modernização dos Complexos Navais. Rio de Janeiro, 2016. 161p. Dissertação de Mestrado. Departamento de Engenharia Civil, Pontifícia Universidade Católica do Rio de Janeiro.

A consciência de que os recursos são finitos e de que é necessária a sua preservação é uma nova forma de se relacionar com a natureza. E um grande impacto no meio ambiente é o lançamento de efluentes nos corpos hídricos. Na Marinha do Brasil, modernizar o sistema de esgoto tem sido um grande desafio, o que abrange desde a destinação dos recursos orçamentários e gestão dos projetos até a execução das obras e manutenção das Organizações Militares de Terra e os licenciamentos ambientais. Neste contexto, diversas questões relevantes foram identificadas como a deficiência dos recursos orçamentários, a interferência que gera erros na execução advindas dos projetos de engenharia, a necessidade de substituição do sistema de tratamento de esgoto atual de fossa séptica e filtro anaeróbio de fluxo ascendente e de interligar o máximo de construções terrestres ao sistema público, superando-se os desafios encontrados nos casos concretos analisados e implementar ações que enquadrem os casos de preparo e emprego da força na dispensa legal de licenciamento ambiental. Diante dos desafios dessas questões, sugere-se a otimização da gestão dos recursos públicos, inclusão da fase de compatibilização dos projetos de engenharia, emprego de estações compactas de tratamento de esgoto em substituição ao sistema fossa séptica-filtro anaeróbio de fluxo ascendente, interligar o máximo de construções possíveis aos sistemas públicos e definir quais são as atividades de preparo e emprego das forças que se enquadram na norma. Todos os procedimentos apresentados são acompanhados de indicação de rotinas e ações que pretendem colaborar com a melhoria do desempenho ambiental do sistema de esgoto da Marinha do Brasil.

\section{Palavras-chave}

Meio Ambiente; Sistema de esgoto; Licenciamento ambiental. Desempenho ambiental; Marinha do Brasil. 


\section{Extended Abstract}

Silva, Vania Menezes Pereira da; Romanel, Celso (Advisor); Costa, Ernani de Souza (Co-advisor). Sewer System in Brazilian Navy: issues to modernize naval complex. Rio de Janeiro, 2016. 161p. MSc Dissertation. Departamento de Engenharia Civil, Pontifícia Universidade Católica do Rio de Janeiro.

There is no doubt about the importance of water to life. All kind of life in this planet needs water to born and survive in a healthy way. So, it is a fact that if the water becomes poisoned, we are poisoned, if it is not potable, we will be sick. That is why we must take care about our water resources and we must do something immediately or life in Earth will be exterminated.

It is not a single screaming. United Nations Climate Change conference has been talking about it for many years and each case scenario is getting worse year by year. The oceans, rivers and lagoons have got to be protected. And have many standards to prevent them from destruction but usually it is not successful. Specially at urban cities because there are many different interferences that achieve people's health. One of it is sewer. It goes into oceans, rivers and even into sources that are underground and sometimes without any kind of sewage treatment.

It is very important to understand that sanitary sewers are composed of almost $90 \%$ of water; and that is the reason why if it is disposed back into sources without an effective cleaning process, it will contaminate all kind of water sources that exists until they reach unsupportable limits to life. And, when life finds too many difficulties to exist in a certain river or other source, it means that they are dead or useless.

Sanitary sewer is composed of many things such as organic, metallic and nonmetallic elements and it is not right if someone thinks that contributes just with organic elements. When someone put away batteries, paints, deodorant, antiperspirant or electronics is cooperating to spoil environment. These things are poison to water, each one in different terms of cooperation, but equally danger to water and life itself. And how many of us are not worried about it? Not much. Human beings throw these things off frequently without even thinking about their 
act. But it is fact that each one of us is responsible for providing environment protection.

Definitely, sewage treatment is a very important way to protect our water sources but it is not the only way to protect them. Environmental education is also necessary. Brazil has a big challenge in this matter because we have so many different social problems in a large territory and not too much money to solve it. In this scenario we have to do the best efforts to make the correct choice in order to use technics and new ideas with creative initiative making an efficient management to make people thing about their own responsibility on protecting environment.

Protect environment is also prevent diseases and if you do not have a potable water to drink or a sea/river/lagoon free from organic contamination to be in contact with and also have fun maybe human beings will be sick and even die.

Sewage treatment has many standards in Brazil and it seems to be sufficient to have a good performer sewage treatment system. So even if a sewage treatment have interferences it is expected that it fits properly number of users, have minimal environment impact, collect the total amount flow, disposal of formed gases and ensure tightness regarding the possible return of liquids and foreign materials in the system. These technical procedures must be considered in order to have a sustainability system, treating and disposing in good quality effluents into environment. In other words it means good environmental performance.

It would be better if sewer goes direct to a public system but sometimes it is not done because of there is no nearby public system with a trunk sewer collector. If it not happens there are many technics of sewer treatments and it is necessary to do feasibility studies to make the right choice between this technic or that technic in a minimum safety factor.

Brazilian Navy is the naval service branch of Brazilian Armed Forces. To be in order to conduct naval operations it has 280 constructions just as naval districts and naval bases. It means that there is hard construction maintenance to be done. But it is not the focus in armed forces which must provide security and protection using weapons and power. So the challenge is to use correctly the government funds to do all needs and be up to date in country's protection and 
safety. And to do all these things with minimum efforts and maximum performance is a goal.

One problem is that Brazilian Navy constructions have different ages and many of them are very old. Because of many different factors the sewage treatment system was not modernized in many naval districts and naval bases. And it rarely happens in those who are far from centers because of the difficulty of urbanizing it.

These naval districts and naval bases far from centers usually do not have a nearby public system with a trunk sewer collector and it is a usual practice to use septic tank and anaerobic filters to discard sewage. But it is also true that even in urban constructions this technic is used.

Septic tanks were a usual technic in past and that is why Brazilian Navy has almost $70 \%$ of sewage system using it yet. Year by year in order to modernize sewage treatment system the construction's projects introduced botton-up flow anaerobic filters after septic tanks which improves its performance eliminating over $90 \%$ of organic charge. It means that Brazilian Navy has too much to modernize but using these two systems together it can get better environmental performance.

There are two ways of treating effluents in septic tanks. The first one is a physical treatment to reduce solid residues based on density. The other one is biological and is based on reducing biochemical oxygen demand (DBO) by oxidation. As result from this primary treatment there are four parts just like sludge, scum, water and gases.

The biological treatment begins with microorganisms that are aerobic and nonaerobic in waste which reacts removing air from oxygen and organic substances making the oxidation. During oxidation nitrogen reacts with hydrogen and it turns into ammonia and after it becomes sludge on the base of septic tank and scum on top of surface in septic tank. The third part of it is reactions in water when acids free hydrogen which reacts with rest of oxygen and becomes water. Last portion of this are the gases. The main gases formed are methane and carbon gases.

Septic tank has to be cleaned almost one time a year in order to remove sludge and scum and Brazilian Navy use to do it so as needs occurs. Finally water 
goes due to river/lagoon/ocean and gas goes due to atmosphere and it is expected to be able to return to environment without harming nature.

After biochemical process treatment at septic tanks the organic charge contamination is reduced about to $60 \%$ of organic charge but joining another technic just like botton-up flow anaerobic filter performance can be increased and get better. So a second technic is joined and botton-up flow anaerobic filter is connected after septic tank including one more step of biochemical process eliminating over $90 \%$ of organic charge.

The main goals in a sewage treatment system are minimizing volume and mass of waste delivered to environment, inactivation of biological and chemical processes thus preventing environment from gases production and settlement and extracting contaminants of the waste in order to reduce leachate emissions. These goals can be achieved with these systems together.

Nowadays both septic tanks and botton-up flow anaerobic filters are technics used to discard the sewage to environment but it is not the only one. In order to modernize all system Brazilian Navy is also using wastewater treatment plant. The main challenge is that even this treatment system better results it is more expensive and need some changes in underground pipelines. As result it needs more budgetary resources.

There are many types of wastewater treatment plant. An important type of it is the compact one. Compact wastewater treatment plant use a little space and join anaerobic and aerobic tanks in a simple technic achieving a good reducing organic charge performance. Compact wastewater treatment plant is more expensive than using septic tanks-botton-up flow anaerobic filter treatment system. Therefore conducting a cost-benefit analysis is important to make the right choice. It means that better performance is important not only to costs but to nature itself.

Environmental protection is important not only to Brazilian Navy but to all world. It is an obligation that must be observed for all citizens. And use the better technic to make a minimum impact is more than use right technics. It is an important standard to be used and it will guide human being's future. The decision is a hard thing to do but is important to considerer all kind of impact just as environment, constructions, resources, priorities, diseases, space, soil, pipelines interferences. 
Sewage treatment system must have a good performance. And there is no doubt that substitute septic tank-botton-up flow anaerobic filter treatment system to compact wastewater treatment plant is the right thing to do. But it is not a simple decision. At first integrate solutions that include every step of the value chain, from financial resources, project management, contracts up to building sewage treatment systems are also important steps to get argumentation to begin a Brazilian Navy modernization and ask for public funds.

Projects also have to comply with environment standards in order to get its environmental license from Instituto Brasileiro do Meio Ambiente e dos Recursos (IBAMA) or another government agency that grants wastewater licenses.

The definition of the competent government agency is in standards. If it is a global impact it means that the license procedure is at Instituto Brasileiro do Meio Ambiente e dos Recursos (IBAMA). If it is a regional impact it means that the license procedure is at Instituto Estadual do Meio Ambiente (INEA). If it is a local impact it means that the license procedure is at Secretaria Municipal do Meio Ambiente (SMAC).

IBAMA is the rule procedure but this public agency may delegate competence to INEA or SMAC depending on the space impact. So it means that administrative process for environmental license must be presented at first at IBAMA. After it IBAMA will define if it is case of national, regional or local impact and also if it is case of licensing for preparation and employment of armed force which is a special case of no need of grant.

Environmental licensing in military enterprises is not a simple thing to do. It means that sometimes protection and safety cannot be done without some military constructions that make environment impact. This kind of contradiction is not good but when it is a real need it can have a different treatment.

For these needs there is a special federal standard to be used on environmental licensing in military enterprises for preparation and employment of armed force. The environmental licensing for military construction projects is defined in current standard laws. The Federal Law 140/2001 contains a special case of licensing for preparation and employment of armed force. It means that there's exception and the different procedure of licensing is to submit the project to IBAMA to be analyzed in order to be granting or not. So this government 
agency will clarify any question from military enterprises about needing or not environment grant.

In order to make a good stuff to present to government agency arguments to get a grant dispensation it was made a study propose making a split of activities of the enterprises military into three segments in order to support the concept of its meaning and define which one is affected by preparation and employment of armed force.

It was also suggested to do records of images, environmental impact studies, environmental auditing, local history in order to use all these knowledge to have contents to protect environment and also to use it in the procedure to get grant dispensation.

Instead of existing a concept of no need of environmental grant and what are the procedures to do it in Federal Law 97/1999, it requires a less open standard to define exactly what are preparation and employment of armed force. It is expected to be created by the executive branch but it is not done yet. This is a problem because there is no standard deciding which one is the competent authority to do this and that is a difficult thing to decide.

There is no special definition of this competent authority in Federal Law 97/1999 so it appears two possibilities: A presidential act or a ministry act. Both of them have hierarchical authority over armed forces and there are only these two solutions.

The truth is that armed force must be prepared to licensing procedures recording all administrative steps in order to have a strong argument to present when there is no need of grant to environmental agency.

In order to modernize sewage treatment system and get the best environmental performance Brazilian Navy have being making different studies, new engineering projects, improving the training of its staff, using new technics such as constructing compact wastewater treatment plant. It is also improving environmental education making conferences, lectures and courses in order to disseminate instructions to protect environment.

Modernize armed force sewage treatment system is a great challenge and some new and more expensive technics can be included gradually just like compact wastewater treatment plant. It means that modern technics must be included in projects even it will not have funds to be built but it will be known 
since its conception. And if it is already included a correct management of public resources will become a true and it will optimize procedures and at least improve environmental protection.

\section{Keywords}

Environment; Sewarage system; Environmental license; Environmental performance; Brazilian Navy. 


\section{Sumário}

1. INTRODUÇÃO 22

1.1. Contextualização 22

1.2 Organização do trabalho 25

1.3. Referencial teórico 26

1.4. Apresentação do problema 32

1.5. Metodologia 36

2. GESTÃO DO SISTEMA DE ESGOTO: adequando a concepção e a execução

2.1. Considerações iniciais 38

2.2. Desafios na gestão 40

2.3. Estrutura atual do sistema de esgoto $\quad 45$

2.4. As interferências e a gestão com qualidade $\quad 50$

2.5. Procedimentos propostos 56

3. LICENCIAMENTO AMBIENTAL DO SISTEMA DE ESGOTO NOS EMPREENDIMENTOS MILITARES 61

3.1. A importância da preservação do meio ambiente para a Marinha do Brasil

3.2. O sistema de esgoto, as normas ambientais e as auditorias 69

3.2.1 As normas ambientais $\quad 72$

3.2.2. Auditorias ambientais: um instrumento de medição de desempenho 75

3.3. Licenciamento ambiental e os empreendimentos militares de preparo e emprego

3.4. Dispensa do licenciamento ambiental nos empreendimentos militares de preparo e emprego

4. MODERNIZAÇÃO DO SISTEMA DE ESGOTO DA MARINHA DO BRASIL

4.1. Aspectos Gerais

4.2. O sistema público de coleta de esgoto

4.3. O sistema de tratamento e descarte dos efluentes 94

4.3.1 Considerações iniciais $\quad 97$

$\begin{array}{lr}\text { 4.3.2 Fossas sépticas } & 102\end{array}$

4.3.3 Filtro anaeróbio 114

4.3.4 Cotas baixas dos terrenos e proteção do sistema de esgoto 121

$\begin{array}{ll}\text { 4.3.5 Tratamento preliminar nas caixas de gordura } & 125\end{array}$

$\begin{array}{ll}\text { 4.3.6 Procedimentos Sugeridos } & 128\end{array}$

5. MODERNIZAÇÃO DOS COMPLEXOS NAVAIS NA CIDADE DO RIO DE JANEIRO: contribuição para o programa de despoluição da Baía de Guanabara $\quad 132$

5.1. Considerações iniciais 132

5.2. O programa de despoluição na Baía de Guanabara 133

5.3. Estudos de caso 138

5.3.1 Complexo Naval da Ilha das Cobras 138 
5.3.2 Complexo Naval da Avenida Brasil

5.3.3 Complexo Naval da Ilha do Governador 148

5.4. Análise dos estudos de caso e uma visão de futuro 150

5.4.1 Considerações relevantes $\quad 150$

5.4.2 Visão de futuro 152

6. CONCLUSÃO 155

REFERÊNCIAS BIBLIOGRÁFICAS 158 


\section{Lista de figuras}

$\begin{array}{ll}\text { Figura 1.1 Rio Tietê, São Paulo. } & 27\end{array}$

Figura 1.2 Jardim suspenso, Nova York 29

Figura 1.3 Vista superior da Estação de Tratamento de Esgoto (ETE) do

Centro de Instrução Almirante Wandenkolk (CIAW) 30

Figura 1.4 Centro de Adestramento Almirante Marques de Leão 31

Figura 2.1 Construção dos Estaleiros e Base Naval da Marinha 39

Figura 2.2 Distribuição das receitas da União para obras x ano 44

Figura 2.3 Construções na beira dos rios 47

Figura 2.4 Número de OM’s construídas x ano de criação 49

Figura 2.5 Área de superfície com recobrimento insuficiente e mal executado 51

Figura 3.1 Programa de Despoluição da Baía da Guanabara. Ilha do CIAW 63

Figura 3.2 Estação de Tratamento de Esgoto. Ilha do CIAW 64

Figura 3.3 Obras de saneamento do Complexo da Avenida Brasil 64

Figura 3.4 Exemplo de esquema fossa-filtro 66

Figura 3.5 XVI Regata Ecológica na Escola Naval 67

Figura 3.6 Seminário de Meio Ambiente no Arsenal de Marinha no Rio de Janeiro (AMRJ)

Figura 3.7 Operação Amazônia Azul $2014 \quad 68$

Figura 3.8 Competências ambientais constitucionais $\quad 74$

Figura 3.9 Auditoria Ambiental no CIAW 76

Figura 3.10 Quadro atividade x preparo/emprego 85

Figura 4.1 Distribuição nacional do sistema de esgoto 93

Figura 4.2 Distribuição da coleta de esgoto (fossa séptica e rede coletora pública) 93

Figura 4.3 Vista superior da Estação Compacta de Deodoro 104

Figura 4.4 Esquema de uma fossa séptica retangular 112

Figura 4.5 Esquema de uma fossa séptica circular 112

Figura 4.6 Caminhão limpa-fossa 113

$\begin{array}{ll}\text { Figura 4.7 Esquema Fossa-Sumidouro } & 115\end{array}$

Figura 4.8 Esquema Fossa-Valas de infiltração 116 
$\begin{array}{ll}\text { Figura 4.9 Esquema de Valas de filtração } & 118\end{array}$

Figura 4.10 Sistema Fossa- Filtro-Corpo receptor 119

Figura 4.11 Sistema Fossa- Filtro-Sumidouro 119

$\begin{array}{ll}\text { Figura 4.12 Estação compacta de esgoto } & 120\end{array}$

Figura 4.13 Lixo concentrado no gradeamento instalado pelo INEA no

Rio Meriti 122

Figura 4.14 Comporta sobre o canal do Rio Meriti e gradeamento

$\begin{array}{ll}\text { parcialmente solto } & 123\end{array}$

Figura 4.15 Ocupação irregular e assoreamento do Rio Meriti 124

Figura 4.16 Proliferação de algas no Rio Meriti 124

Figura 4.17 Inspeção da Caixa de Gordura da UFEM 126

Figura 4.18 Vista interna da Caixa de Gordura da UFEM 126

Figura 4.19 Tratamento preliminar com Caixa Retentora de Sólidos $\quad 128$

Figura 4.20 ETE compacta 129

ङ $\quad$ Figura 5.1 Vista da Baía de Guanabara 134

Figura 5.2 Vista do Arsenal de Marinha 139

Figura 5.3 Dique Almirante Régis $\quad 142$

Figura 5.4 Vista de parte do Complexo Naval da Av. Brasil 143

Figura 5.5 Bacias de contribuição do Complexo Naval da Av. Brasil 144

Figura 5.6 Arruamento com obras no Complexo Naval da Av. Brasil 146

Figura 5.7 Lançamento de tubulações no Complexo Naval da Av. Brasil 146

$\begin{array}{ll}\text { Figura 5.8 Técnica nova de lançamento das tubulações } & 147\end{array}$

Figura 5.9 Complexo Naval da Ilha do Governador 149 


\section{Lista de tabelas}

Tabela 2.1 Valores de investimentos para a Marinha do Brasil. Lei Orçamentária Anual (LOA)

Tabela 2.2 Responsabilidades Projetista x cliente.

Tabela 3.1 Atividades ou empreendimentos que se submetem ao licenciamento ambiental

Tabela 4.1 Eficiência das fossas sépticas

Tabela 4.2 Eficiência das fossas sépticas 


\section{Lista de equações}

Equação 4.1 Cálculo do volume útil da fossa 110

Equação 4.2 Dimensionamento do filtro anaeróbio 118 


\section{Lista de abreviaturas e siglas}

MB - Marinha do Brasil

DOCM - Diretoria de Obras Civis da Marinha

OM - Organização Militar

ONU - Organização das Nações Unidas.

INEA - Instituto Estadual do Meio Ambiente

CREA - Conselho Regional de Engenharia e Agronomia do Rio de Janeiro

CONAMA - Conselho Nacional do Meio Ambiente

CRFB - Constituição da República Federativa do Brasil

ANA - Agência Nacional de Águas

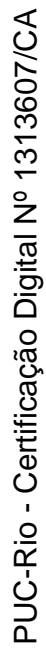

PDBG - Programa de Despoluição da Baía de Guanabara 
"Louvado sejas, meu Senhor,

Com todas as tuas criaturas,

Especialmente o senhor irmão Sol,

Que clareia o dia

E com sua luz nos alumia.

E ele é belo e radiante

Com grande esplendor:

De ti, Altíssimo, é a imagem.

Louvado sejas, meu Senhor,

Pela irmã Lua e as Estrelas,

Que no céu formastes claras

E preciosas e belas.

Louvado sejas, meu Senhor,

Pelo ar, ou nublado

Ou sereno, e todo o tempo,

Pelo qual às tuas criaturas dás sustento.

Louvado sejas, meu Senhor,

Pela irmã Água,

Que é muito útil e humilde

E preciosa e casta.

Louvado sejas, meu Senhor,

Pelo irmão Fogo

Pelo qual iluminas a noite

E ele é belo e jucundo

$E$ vigoroso e forte.

Louvado sejas, meu Senhor,

Por nossa irmã a mãe Terra,

Que nos sustenta e governa,

E produz frutos diversos

E coloridas flores e ervas..."

São Francisco de Assis (Padroeiro da ecologia)

Cântico das Criaturas 


\section{INTRODUÇÃO}

\section{1}

\section{Contextualização}

Modernizar o sistema de esgoto nos quartéis da Marinha requer uma análise das questões que interferem no seu desempenho junto ao meio ambiente. E melhorar o desempenho do sistema de esgoto nos quartéis da Marinha do Brasil é melhorar os resultados esperados de forma estratégica, a fim de que a organização mantenha a coerência dos esforços direcionados à adequação das necessidades e possibilidades existentes. Para aprimorar os resultados, deve-se estudar a situação existente do sistema estudado, coletando dados para que se efetue propostas de novas técnicas, rotinas e procedimentos, tudo com o fim de reorganizar ações e reformular técnicas.

Essa colaboração se apresenta organizada no Capítulo 1, que contém os aspectos teóricos e metodológicos da pesquisa contextualizando o problema e apontando para as possíveis soluções. O que se espera do sistema de esgoto é que ele atenda de forma adequada ao número de usuários e tenha um mínimo de impacto no meio ambiente, devendo ser observada a coleta de toda a contribuição dos seus efluentes, um escoamento total deste montante e eliminação dos gases ali formados, a garantia da estanqueidade, no que concerne ao possível retorno de líquidos e materiais estranhos ao sistema, bem como o descarte dos efluentes de forma a se coadunar com os preceitos da sustentabilidade, ou seja, interferindo minimamente no meio ambiente.

É importante que os efluentes sejam tratados e lançados ao meio ambiente, de forma a minimizar, ao máximo, o seu impacto. E é certo que, ainda que seja enviado para um sistema público, este efluente deve afetar o menos possível o sistema de tratamento público, para que diminua custos e, especialmente, contribua para a melhor qualidade do retorno às águas tratadas ao meio ambiente.

Todo o sistema deve ser concebido em um projeto que garanta o menor número de interferências durante a execução das obras, observando a 
compatibilização das etapas, desafio cujas soluções são apontadas ao longo do Capítulo 2. E um bom planejamento é importante para a correta gestão desde o início das decisões, quando ocorre a priorização na distribuição dos recursos. Este primeiro passo deve ser considerado quando da análise sistêmica do sistema de esgoto, pois o resultado de uma decisão equivocada irá influenciar ao longo de todo o funcionamento do sistema.

O sistema de esgoto nos quartéis da Marinha do Brasil abrange tanto reformas e ampliações de edificações já existentes, por vezes de longa data, quanto às construções novas. Na maioria das vezes, porém, são reformas e ampliações para adequar o sistema de coleta e tratamento ao novo número de usuários, o que não representa uma efetiva modernização. Para que estas obras ocorram, antes é necessário um devido planejamento, tanto da concepção do projeto, quanto da escolha da melhor empresa que, no caso, é a licitante com o menor preço de oferta, procedimento previsto na lei de licitações, ou seja Lei $n^{\circ}$ 8.666 (BRASIL, 1993), que tem por principal objetivo garantir a escolha da melhor proposta e a transparência do contrato a ser celebrado com a terceirizada. Este procedimento licitatório, no entanto, pode gerar alguns óbices, como a falta de compatibilização entre os diversos projetos de engenharia e erros na execução da obra, como se poderá ver ao longo do trabalho.

No que tange à observância das normas técnicas e ambientais, o sistema de esgoto nos quartéis da Marinha do Brasil tem atendido aos anseios da Administração Pública. Entretanto, ainda restam diversas instalações antigas necessitando de reformas, ampliações ou modernizações. Apesar da boa técnica aplicada às novas construções, constata-se a necessidade da modernização de diversas instalações e o implemento de novos equipamentos destinados ao tratamento e descarte dos efluentes, a fim de que se submetam ao rigor ambiental dos tempos atuais, bem como a uma nova estrutura física que permita um maior conforto e segurança aos seus usuários e a população do entorno, especialmente se despejados os efluentes diretamente nas águas dos rios e mares, situação que requer a melhor qualidade possível dos efluentes para ali destinados.

Isto acontece por diversas razões, até por questões históricas, já que muitas das instalações datam de séculos atrás, por ser a Marinha do Brasil a força mais antiga da nossa república, além da insuficiente distribuição dos recursos da União que tem sido gerenciada de forma a envidar todos os esforços para a sua ótima 
utilização, por meio de técnicas de contabilidade e administração. Toda essa problemática é discutida com ações sugeridas ao longo do Capítulo 2.

Uma questão que interfere diretamente na modernização das instalações é o licenciamento ambiental, como se discute ao longo do Capítulo 3. Destaca-se no presente estudo os casos dos empreendimentos militares, de preparo e emprego da força, em que se deve percorrer por uma análise sistêmica das leis que tratam do assunto, pois, para cada atividade desenvolvida nas Organizações Militares, há de se verificar se é caso ou não de dispensa do licenciamento ambiental pelos órgãos ambientais, como previsto em lei.

Estabelecer metas e procedimentos em busca de melhores resultados, por meio da análise e interpretação dos dados obtidos em levantamento do sistema existente na Marinha do Brasil, também requer o estudo do gerenciamento na concepção dos projetos e coordenação destes durante a execução das obras, sendo isto uma visão sistêmica e necessária para um bom fluxo do processo construtivo. Além disso, analisar outras questões tais estudar a tecnologia indicada para o tratamento dos efluentes nos lugares aonde não existem redes públicas; pesquisar uma técnica que garanta a coleta dos efluentes com bom escoamento e estanqueidade, bem como impedir o retorno de líquidos ao sistema nos terrenos localizados em cotas baixas, em decorrência das marés altas e chuvas fortes, são questões que foram consideradas de relevante interesse ao longo dos Capítulos $4 \mathrm{e}$ 5 , com o fim de modernizar o sistema.

E muitas foram as dificuldades observadas ao longo de anos por projetistas e fiscais da Diretoria de Obras Civis da Marinha, órgão responsável pela elaboração de projetos de engenharia e licitações de grande porte para edificações terrestres na Marinha do Brasil.

Assim, a pesquisa tem por objetivo indicar soluções com sugestões de ações que permitam a melhoria da gestão nos projetos de engenharia, indicando a compatibilização de projetos para eliminar erros durante a execução das obras, um planejamento eficiente, prévio e realista, desde o projeto básico até a execução da obra; o bom exercício do comprometimento na defesa do meio ambiente, avaliando os tipos de atividades desenvolvidas nas Organizações Militares, de preparo e emprego da força, a fim de verificar a incidência ou não de dispensa legal do licenciamento ambiental, assim como a análise das necessidades e dificuldades existentes sugerindo-se a instalação das estações compactas de 
tratamento de esgoto para a uma modernização do sistema de esgoto em substituição ao atual sistema de fossa-filtro, tudo conforme concluído no Capítulo 6.

De certo, o presente estudo pretende não exaurir o assunto, mas dar início e incentivar o aprimoramento do sistema de esgoto nos quartéis da Marinha do Brasil, a fim de modernizar as suas instalações, apresentar rotinas para melhoria da gestão e da própria eficiência das instalações, bem como eliminar, a curto e médio prazo, os impactos ambientais que ainda ocorrem em decorrência do atual sistema, melhorando o desempenho de todo o sistema. Além disso, é expectativa deste instrumento servir de subsídio e referência prática para outros órgãos administrativos públicos, a fim de permitir que seja uma fonte de consulta, a eliminar os equívocos que poderiam ocorrer por falta de dados conhecidos para bem subsidiar as decisões dos administradores públicos.

\section{2}

\section{Organização do trabalho}

O trabalho foi desenvolvido em 6 (seis) capítulos, distribuídos de forma a apresentar as situações identificadas como principais interferências no desempenho do sistema de tratamento de esgoto da Marinha do Brasil, situações estas resultantes do levantamento de dados na Diretoria de Obras Civis da Marinha. Com estes dados são apresentadas linhas de ação sugeridas para a solução destes problemas e estudos de casos em que são analisadas as soluções adotadas atualmente e identificadas as principais deficiências dessas soluções. $\mathrm{Na}$ conclusão apresenta-se um resumo das diversas soluções apontadas nos capítulos anteriores.

Dessa forma a organização do trabalho segue um sistema de sucessão de problemas identificados que influenciam negativamente o desempenho do sistema de esgoto existente com as consequentes soluções encontradas em cada capítulo, conjugadas em uma conclusão que indica a necessidade de implementar uma gestão mais eficiente dos projetos, com a compatibilização das diversas áreas da engenharia, modernizar o sistema com a instalação de estações compactas de tratamento de esgoto e priorizar recursos orçamentários para que todas essas soluções possam ser implementadas em um gerenciamento eficiente. 
No Capítulo 1, expõem-se os motivos e as questões relevantes da pesquisa, no que se apresentam a situação existente e as necessidades da Marinha do Brasil, bem como a metodologia de trabalho, fundada na coleta de dados e análise à luz das técnicas existentes, encerrando-se com a exposição da organização do trabalho e os resultados esperados. No Capítulo 2, analisa-se a questão da gestão do sistema de esgoto, acrescido da análise da estrutura existente e das interferências entre as redes e projetos, do que resultam dificuldades encontradas no binômio concepção de projeto-execução de obras, o que também é causa de grandes problemas que se perpetuam a longo prazo no sistema de esgoto. No Capítulo 3, estuda-se a possibilidade de dispensa legal dos licenciamentos ambientais nos empreendimentos militares de preparo e emprego, sugerindo-se uma análise de interpretação sistêmica das normas vigentes, bem como uma adequação com a apresentação de uma tabela de atividades e com procedimentos de registro de dados para a adequação das decisões administrativas; no Capítulo 4, discorre-se sobre a coleta e o tratamento dos efluentes na Marinha do Brasil, incluindo procedimentos e rotinas de operação sugeridas; no Capítulo 5 apresentam-se estudos de casos de Complexos Navais na cidade do Rio de Janeiro, que se encontram em franca adequação às normas ambientais, especialmente no que concerne à qualidade do descarte e sua consequente contribuição na despoluição da Baía de Guanabara e, por último, no Capítulo 6, apresentam-se as Conclusões.

\section{3}

\section{Referencial Teórico}

A água é elemento vital para a manutenção de vida do planeta. Entretanto, para que seja consumido, necessita ser de boa qualidade para o consumo, que ocorre com diversas finalidades, seja industrial, seja para a produção de alimentos, seja para a higiene ou para o próprio consumo do homem. Como informa DE ARAUJO e NUVOLARI (2012, p. 17), já nos tempos mais remotos a coleta de águas servidas, que hoje chamamos de esgoto sanitário, passava a ser preocupação daquelas civilizações. E essa necessidade foi aumentando em proporções correlacionadas com o aumento populacional. Assim, iniciaram-se as doenças e mortandades conhecidas na história, muitas em decorrência dos efluentes contaminados. O sistema separador absoluto foi concebido somente em 1979, 
como citado por DE ARAUJO e NUVOLARI (2012, p. 19), quando surgem as canalizações exclusivas para o transporte dos esgotos sanitários, o que foi implantando em Memphis, Tenessee, nos Estados Unidos da América. O engenheiro J. P. de Jesus Netto apresentou estudos que demonstravam a degradação do Rio Tietê em 1933, uma situação que apresentava a preocupação com o saneamento local já naquela época. Veja-se a situação atual do Rio Tietê, conforme figura 1.1, de lamentável morte progressiva. Se os estudos técnicos fossem considerados nas decisões administrativas, não haveria esta realidade lamentável nesta década. O Rio Tietê pode ser considerado morto, sem possibilidade de absorver qualquer carga orgânica ou prover qualquer reação química em cadeia para a sua oxigenação.

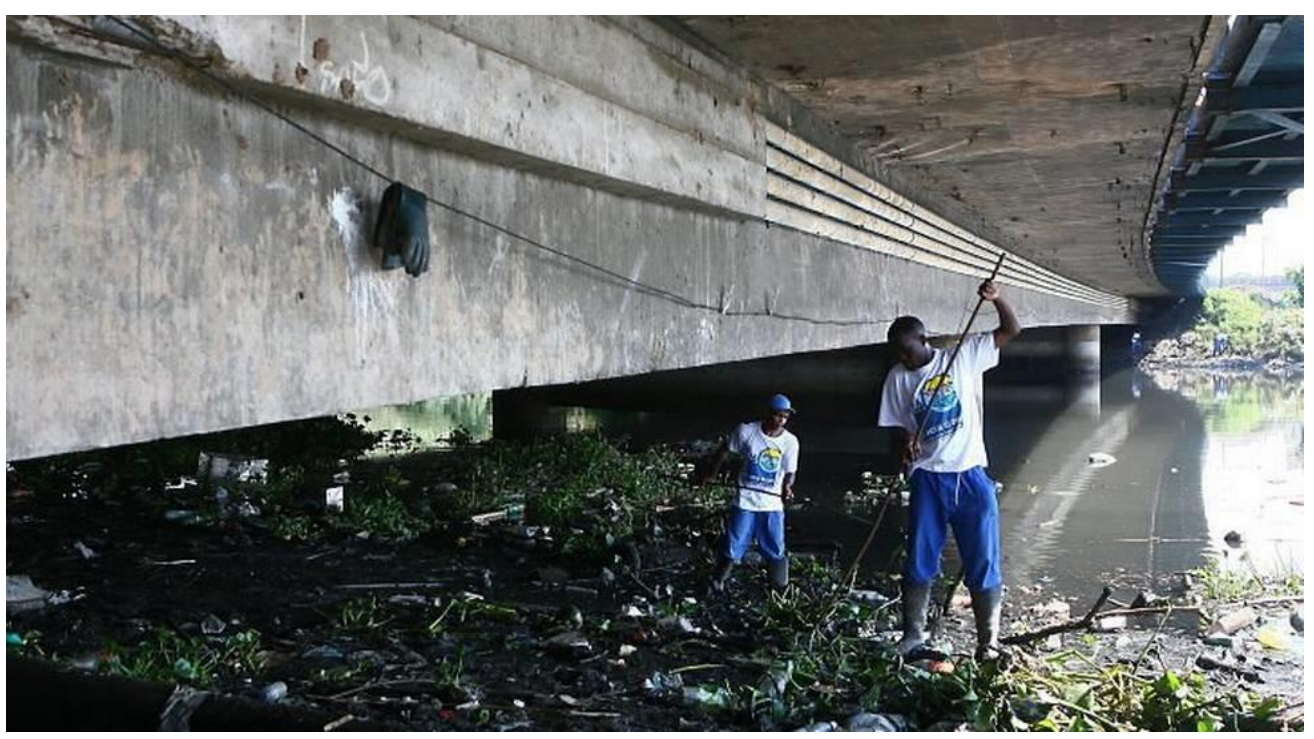

Figura 1.1: Rio Tietê, São Paulo. Fonte: Google (www.google.com.br).

O esgoto doméstico, parte em que se delimita o presente estudo, segundo DE ARAUJO e NUVOLARI (2012, p. 37), é gerado a partir da água de abastecimento e, portanto, sua medida resulta da quantidade de água consumida. Essa é geralmente expressa por "taxa de consumo per capita”, ou seja, por pessoa. Isto submete a avaliação segundo os hábitos e costumes locais, portanto variável.

Os fluidos do esgoto possuem características físicas, segundo DE ARAUJO e NUVOLARI (2012, p. 43), que recebem influências externas que provoca o movimento das partículas, umas em relação às outras. E a forma com 
que o líquido reage às solicitações externas depende de suas propriedades físicas, o que depende das propriedades físicas deste líquido. O mesmo autor, cita:

O esgoto é um líquido cuja composição..., quando não contém resíduos industriais, é de aproximadamente:

$99,87 \%$ de água

$0,04 \%$ de sólidos sedimentáveis

$0,02 \%$ de sólidos não sedimentáveis; e

$0,07 \%$ de substâncias dissolvidas

Assim, sendo majoritariamente formado de água, é tratado em seu escoamento como se fosse água. E nos seus condutores, é tratado sob um escoamento livre, ou seja, sua seção não fica completa de líquido, mas sim, divide-se entre o líquido e os gases e ocorre de forma permanente e uniforme.

Uma das principais causas da contaminação dos corpos hídricos é o despejo de efluentes ao longo dos corpos receptores. Lançamentos efetuados, sem qualquer precaução ou cuidado com o meio ambiente, tanto contaminam as águas como desequilibram todo o sistema ambiental que ali existe, afetando diretamente a sustentabilidade de todo o planeta.

No mundo, diversos países já se preocupam com estas questões e tem introduzido diversas técnicas que minimizam o impacto ambiental nos lançamentos dos efluentes do esgoto para a natureza, melhorando o desempenho do sistema. Segundo a Professora Maria Fernanda Lemos, em aula ministrada no Curso de Mestrado Profissional em Engenharia Urbana e Ambiental na PUC-RIO (2013), a área urbana comporta um sistema de iteração sinérgico entre a natureza, o ambiente construído e a configuração socioeconômica. E tudo isso deve ser analisado em conjunto quando se trata de estudo sobre o sistema de esgoto, pois este deve se coadunar com a concepção de cidade sustentável, sob a ótica da cidade resiliente que, dentre as diversas características, considera a contraposição entre o padrão de consumo crescente e a oferta de recursos naturais. Além disso, não se deve ignorar o impacto sobre a saúde humana e a necessidade de efetuar um estudo sistêmico, que contextualize o problema sob as óticas ambiental, social, cultural e econômica, como acrescenta a Professora Maria Fernanda:

A sustentabilidade da cidade não se refere somente às questões ecológicas em sua relação com o ambiente (consumo de recursos e energia, devolução de resíduos, gases e efluentes), mas também no que se refere ao impacto sobre a saúde humana e a vida em sociedade... Embora muitos princípios sejam comuns, as 
soluções apropriadas na busca por um ambiente sustentável devem partir do contexto específico ambiental, social, cultural e econômico, e de uma escala apropriada de soluções em relação ao objeto e ao desafio a ser enfrentado.

E é sob esta meta que se propôs um estudo do sistema de esgoto numa visão ampla, abrangendo desde os aspectos administrativos, que começam pelo orçamento disponível, passando por questões ambientais, técnicas e normativas, com o fim de adequar a Marinha do Brasil às necessidades de equilíbrio ecológico com a convivência harmônica com o meio ambiente.

Existem soluções que podem ser repetidas no Brasil, especialmente para a melhoria dos corpos receptores. Em Nova York, segundo a Professora Cecília Herzog, em aula ministrada no Curso de Mestrado em Engenharia Urbana e Ambiental na PUC-RIO (2013), na área de drenagem, estão sendo instalados jardins suspensos, conforme figura 1.2, com o fim de melhorar a permeabilidade da cidade, o que afeta diretamente a drenagem da cidade e, consequentemente, a qualidade das águas escoadas para os rios e mares. Em Cingapura, há um planejamento urbano que prevê com a antecedência de 40 a 50 anos a forma de uso do solo, como informa Urban Redevelopment Authority - URA (2012), e este planejamento tem a composição financeira que o apoia, fato fundamental para o êxito das metas.
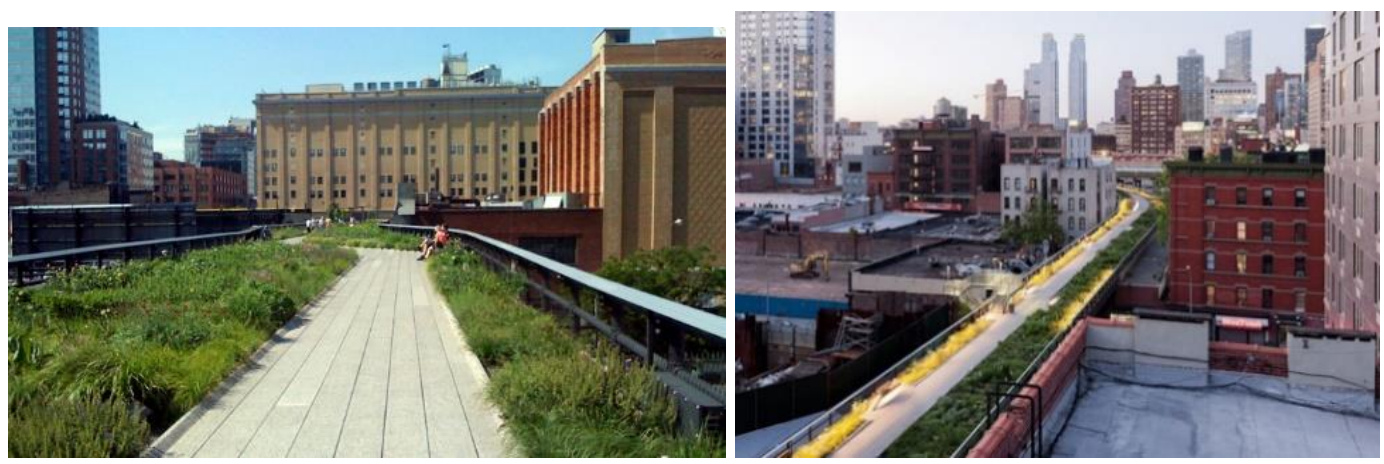

Figura 1.2: Jardim Suspenso, Nova York. Fonte: http://aldeiatem.com/post/1700/jardimsuspenso.

No Brasil, há setores que merecem atenção para a melhora do sistema de esgoto, especialmente na área de planejamento urbano. A já efetivada ocupação ao longo dos rios e suas retificações dificulta a adoção de liberação das margens para a revitalização dos rios, cuja população transborda lixos sólidos juntamente com o esgoto diretamente para estes corpos receptores, cria consequências catastróficas 
para todos e para o Estado. Aliás, outra consequência pior é a ausência de educação ambiental, pois a falta de consciência dos problemas decorrentes permite que, além da ocupação irregular, sejam lançados diretamente nos corpos d'água todo o tipo de lixo e não somente os efluentes do sistema sanitário.

No que tange aos licenciamentos ambientais para os empreendimentos militares, o que inclui os licenciamentos das Estações de Tratamento de Esgoto, como a do CIAW ilustrada na figura 1.3, construções de píeres, cais e outras obras de arte às margens dos rios e mares, dentre demais necessidades de apoio à missão da Marinha do Brasil, existe grande controvérsia decorrente da inércia do poder executivo de emitir uma norma que dê efetividade aos casos de dispensa do licenciamento nos casos de preparo e emprego da Força Armada.

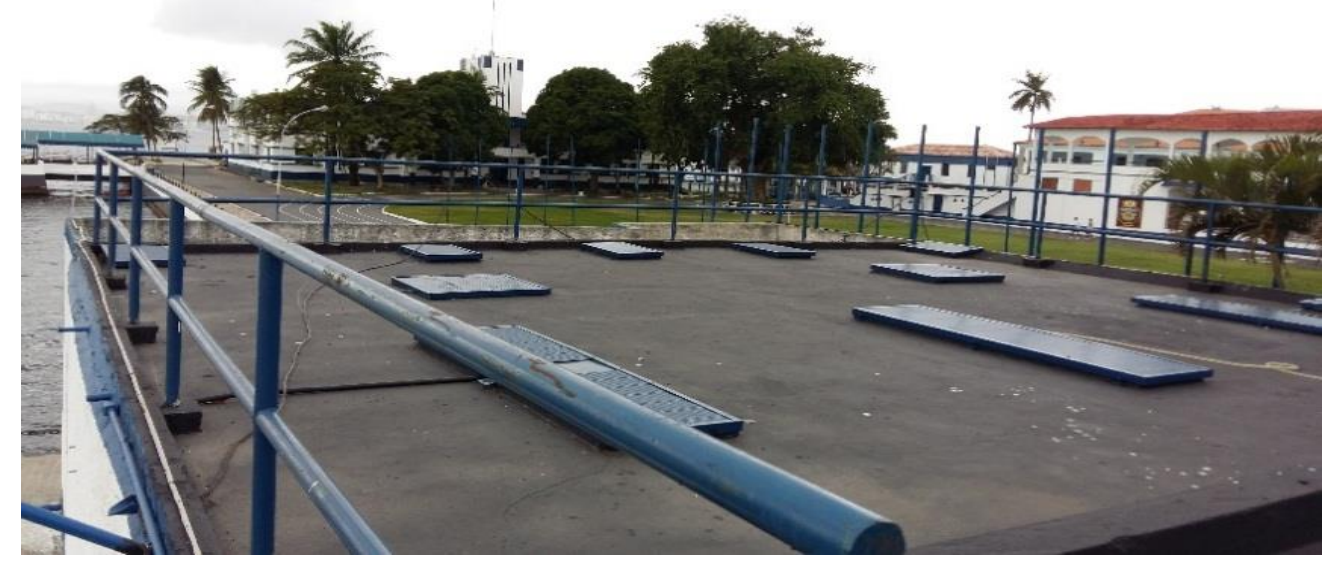

Figura 1.3: Vista Superior da Estação de Tratamento de Esgoto (ETE) do Centro de Instrução Almirante Wandenkolk (CIAW). Fonte: a autora.

Algumas diretivas são sugeridas para que se possa definir as atividades executadas nas Organizações Militares (OM’s) e agrupá-las em segmentos, de forma a permitir a aplicação da norma da forma mais preventiva e com a observância do princípio da precaução previsto no direito ambiental, para que se possa atuar com segurança quando de uma possível análise da dispensa pelo órgão ambiental.

$\mathrm{O}$ estudo do enquadramento das atividades militares parte da análise efetuada por DA CRUZ (2014), que agrupa as Organizações Militares em 3 (três) distintos segmentos, com o fim de analisar o seu potencial danoso para definir a aplicação das auditorias ambientais e, por conseguinte, definir os casos de 
dispensa dos licenciamentos ambientais nos empreendimentos militares pelos órgãos ambientais.

Além disso, o estudo permeia outra questão importante que é a enorme distância ente as leis ambientais e técnicas e a sua efetividade. De um lado os usuários dependentes da disponibilização de um sistema de esgoto adequado, que em sua maioria representa um grupo social de baixa renda e que vive em situação precária. E nesta situação moram sem possuírem ligação dos efluentes decorrentes dos seus vasos sanitários, lavatórios e chuveiros ao sistema público de coleta de efluentes, ou sem a coleta do lixo que acaba sendo lançado ao longo dos rios durante as chuvas, além, é claro, de forma direta pelos próprios moradores.

$\mathrm{Na}$ Marinha do Brasil, grande parte das instalações datam de períodos distantes e dependem de manutenção constante, como no CAAML, figura 1.4, além de ampliações em decorrência do aumento de usuários e adaptações técnicas para a modernização do sistema, especialmente no que tange ao aumento de chuvas e elevação dos níveis dos rios e mares, que, por vezes, provocam refluxos nos sistemas que desembocam diretamente nestes corpos receptores, o que reduz a sua eficiência.

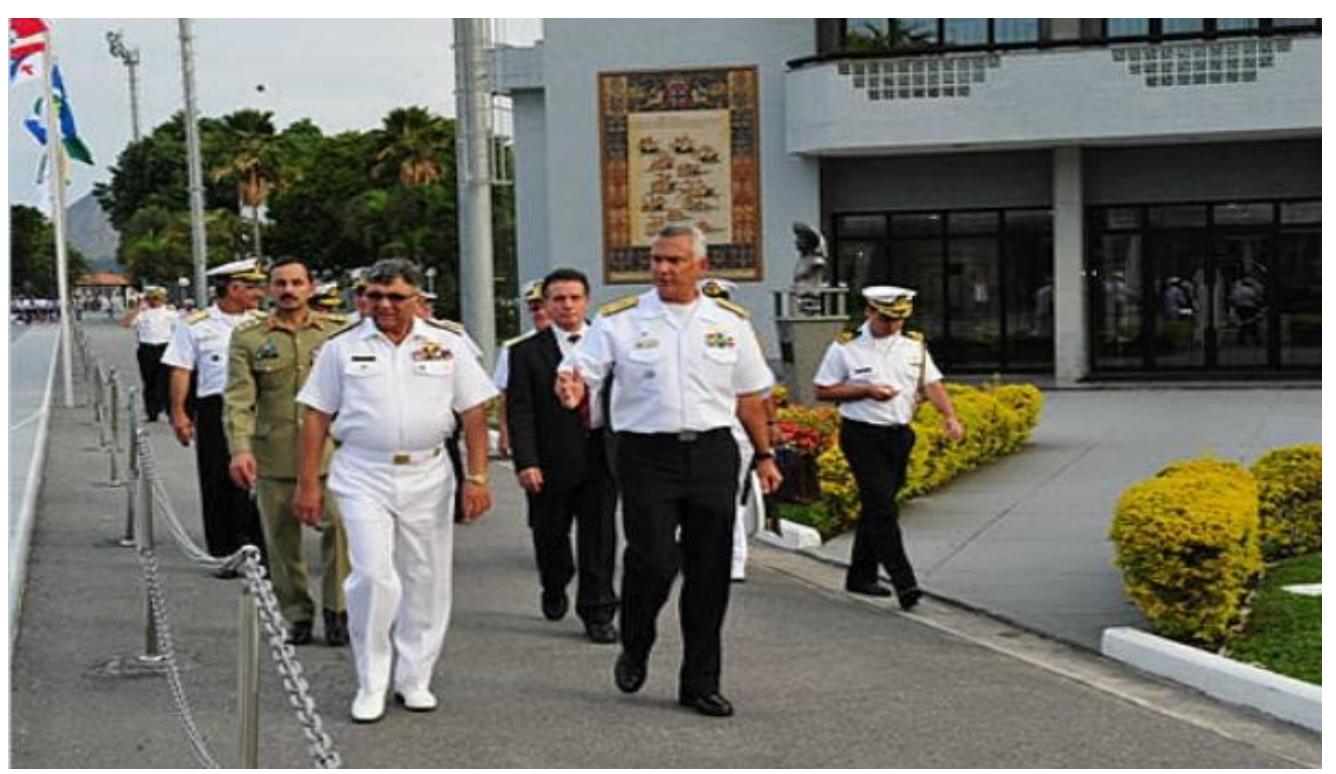

Figura 1.4: Centro de Adestramento Almirante Marques de Leão (CAAML), Parada de Lucas. Criação em 1943. Fonte: www.mb.mar.mil.br.

Existem normas internas que regulamentam a execução dos projetos relacionados às instalações hidrossanitárias. Além destas normas, a Marinha do Brasil observa as normas técnicas e a todas as normas pertinentes, incluindo as 
normas ambientais. Ainda assim, diante de limitações de várias espécies, como limitação de recursos orçamentários, dependência de execução dos serviços por meio de contratos com empresas, decorrentes de licitações, finitude de recursos de mão-de-obra, dentre outros, a gerência de todo o processo é efetivada com empenho e otimização dos recursos, resultando em um estado aceitável do seu sistema de esgoto.

Dessa forma, para que haja um melhor resultado com os mesmos recursos, analisam-se questões consideradas relevantes para a modernização dos Complexos Navais, desde a concepção do projeto até a própria execução das ações decorrentes, que representam a busca da modernização do sistema de esgoto para a melhoria do seu desempenho.

\section{4}

\section{Apresentação do Problema}

O sistema de esgoto é um conjunto de elementos de engenharia que possui a importante função de coletar e descartar os efluentes, em boas condições hidráulicas e atendendo aos limites de carga orgânica ou química previstos nas normas, além de observância dos licenciamentos ambientais. Para tanto, os efluentes devem possuir características diversas, desde que seja compatível com a possibilidade de ocorrência de um contato humano, seja na forma de consumo, seja na forma de contato periférico, como contato com pele ou sistema respiratório. Sob esta ótica, percebe-se que o controle responsável é de importância ímpar, seja pelos próprios órgãos internos de controle, seja nos órgãos externos ambientais, que se materializam em processos de fiscalização e processos de licenciamento ambiental.

Segundo JORDÃO e PESSOA (2011, p. 7), o lançamento indiscriminado dos esgotos nos corpos d'água, sem tratamento, pode causar vários inconvenientes. Em seu estudo, indica fatores ligados às matérias orgânicas solúveis, matérias tóxicas e íons de matais pesados, cor e turbidez, elementos nutritivos, óleos e matérias flutuantes, ácidos e álcalis, temperatura e outros. E acresce que estes inconvenientes, se apresentam com maior ou menor importância, de acordo com os efeitos adversos que podem causar aos usos benéficos das águas. Com isso, conclui que a poluição causada nos corpos d’água 
pelo lançamento de esgotos sem tratamento, ou com tratamento parcial, é função das alterações da qualidade ocasionadas no corpo receptor, e das implicações relativas às limitações aos usos da água.

Para que um sistema de esgoto represente adequabilidade entre o descarte e a qualidade deste, é necessário que sejam controladas todas as suas fases de processo de encaminhamento dos efluentes. E para este encaminhamento, deve-se manter um arquivo com a memória do seu encaminhamento e diâmetros das tubulações e dispositivos. Para tanto, há novos recursos como os sistemas de georeferenciamento, que permitem a manutenção do histórico e garantem a compatibilidade entre a situação existente e os futuros projetos, causa essa de grandes problemas durante a execução dos contratos.

Assim, desde o levantamento das necessidades e da programação dos recursos necessários, até a programação da sua execução, passando por etapas intermediárias de concepção de projeto, compatibilização dos projetos das diversas áreas do conhecimento, processos licitatórios e ambientais e sua efetiva execução, há necessidade da devida atenção com o cuidado que se requer e merece, pois cada etapa é dependente da anterior e sujeita-se as suas consequências boas ou más.

E nesta linha, objetivar um melhor desempenho do sistema é transportar com eficiência e adequação os efluentes gerados até o destino final, seja um coletor público, seja um corpo hídrico receptor, atendendo as normas técnicas vigentes e tendo como principal condutor das intervenções na natureza a responsabilidade da manutenção e preservação do meio ambiente. E tudo isso concatenado ao rumo para a meta de modernização do sistema de esgoto.

Embora todas estas etapas sejam observadas na Marinha do Brasil, algumas questões ainda requerem melhorias e são pontos críticos que merecem ser analisados. Por serem de relevância e interesse não somente para a Marinha do Brasil, mas também para outros órgãos públicos que possuem edificações nas mesmas condições de distribuição territorial e idade de construção, a presente pesquisa tem o fim de contribuir para a melhoria do sistema de esgoto, em uma dimensão multifacetada unindo gestão administrativa e operacionalidade técnica. Muitas necessidades não são atendidas com o imediatismo que se requer. Com isso, existindo mais de 280 Complexos Navais, com edificações que datam do século passado, o desafio de executar a manutenção e modernização do sistema de 
esgoto é grande. Segundo dados levantados no Departamento de Planejamento da Diretoria de Obras Civis da Marinha, órgão público da Marinha do Brasil responsável pelos projetos e obras de grande vulto, um percentual de aproximadamente $70 \%$ (setenta por cento) das edificações da instituição ainda utiliza o sistema de descarte dos efluentes de esgoto fossa-filtro, ou seja, um descarte dos elementos orgânicos diretamente para o meio ambiente com um bom grau de contaminação.

Isso ocorre tanto pela necessidade de modernização nos sistemas de esgoto, com substituição de linhas e construção de estações de tratamento, quanto pela existência, em diversos pontos do Brasil, de dificuldade de conexão do sistema com o coletor público para que se faça a ligação para o sistema público de coleta dos efluentes. E quando surge a ligação e disponibilidade do coletor, ainda há um espaço de tempo para que se execute o que foi planejado, o aguardo da efetiva obtenção dos recursos financeiros que, por vezes, só surgem em créditos previstos no orçamento, as etapas do processo de licitação com a contratação da empresa construtora e somente então ocorrerá a execução da obra.

Outra opção de lançamento do efluente para o meio ambiente com qualidade e eficiência é a construção de Estações de Tratamento de Esgoto (ETE) para um tratamento prévio ao descarte, que garante as características mínimas como temperatura, sólidos em suspensão, sólidos totais, sólidos sedimentáveis, $\mathrm{pH}$, salinidade, teor de matéria orgânica, quantidade e tipos de metais, coliformes fecais. Segundo CAMPOS (1999, p. 20), ao iniciar o levantamento de dados para a elaboração de projetos de sistema de tratamento de esgoto, deve ser observada a determinação da qualidade e da quantidade dos esgotos que serão encaminhados à estação depuradora.

Em muitas Organizações Militares as ETE’s já são uma realidade, como no caso do Centro de Instrução Almirante Wandenkolk (CIAW), mas a sua manutenção requer mão de obra especializada e materiais químicos, além, é claro, da manutenção das bombas e as suas instalações elétricas. Tudo isso necessita de um orçamento permanente anual e impacta a disponibilidade financeira, justamente em um momento de transição econômica em que a União diminui ano a ano os recursos destinados aos órgãos públicos, na contramão de assentamento de sistemas de tratamento de esgotos, que requerem recursos financeiros. Essa realidade, contudo, não pode ser óbice para a priorização da solução tecnicamente 
correta. Assim, elaborar projetos com as soluções técnicas adequadas é a melhor forma de se obter, a longo prazo, a correção desta distorção de técnicas antigas perante as novas técnicas de tratamento e descarte dos efluentes.

São muitos os desafios a transpor, incluindo-se a avaliação correta da atividade exercida na Organização Militar, para definir a dispensa ou não do licenciamento ambiental pelo órgão ambiental, nos casos de empreendimento militar de preparo e emprego da força, analisados à luz das normas vigentes.

Distribuir de forma ótima os limitados recursos orçamentários para tantas necessidades distintas; compatibilizar os projetos executados por empresas terceirizadas distintas, em consequência de contratos gerados por licitações; modernizar o sistema de esgoto, efetuando-se levantamentos do encaminhamento das tubulações por meio do sistema de georeferenciamento e verificar se há interferências, entupimentos ou interceptação de redes, efetuar o planejamento de limpeza das fossas, proceder a análise dos casos de dispensa dos licenciamentos ambientais nas Organizações Militares de preparo e emprego da força; executar as ligações aos coletores públicos ou a construção de ETE's e adequar os sistemas de esgoto aos programas públicos de proteção ambiental são exemplos que espelham a dimensão do caminho a trilhar, o que requer pesquisa no sentido de melhorar o desempenho das etapas a cumprir.

Assim, gerir todo o sistema de esgoto de inúmeras edificações situadas nos 280 Complexos Navais estabelecidos por todo o Brasil é um grande desafio. Gerir com sucesso e produzir a sua melhoria de desempenho é um desafio ainda maior. É obter do sistema o seu melhor resultado. É trabalhar com a eficiência administrativa esperada pela Constituição da República Federativa do Brasil (BRASIL, 1988), conforme estabelecido no seu art. 37. É manter a meta de modernizar o sistema de esgoto nos Complexos Navais, eliminando-se, tanto quanto possível, o sistema fossa-filtro, sistema mais comum no presente momento.

Diante deste objetivo, analisar a situação existente e buscar processos que subsidiem a melhora efetiva do sistema de esgoto, de modo a aliviar a sua contribuição para os corpos hídricos e melhorar a qualidade das águas dos rios e mares por todo o Brasil, bem como proceder adequadamente os licenciamentos ambientais, de forma a empreender a proteção constitucional do meio ambiente, são ações que pode contribuir com o próprio futuro do Brasil, desafios 
permanentes que requerem novas formas de implementação da gestão administrativa de forma estratégica.

Como obter processos que contribuam para a melhora do sistema de esgoto da Marinha do Brasil é uma busca que permeia desde o início da cadeia do sistema, que á a distribuição dos recursos e a eliminação de desperdícios financeiros, até o fim da cadeia, que é o próprio descarte dos efluentes nos corpos hídricos, que no meio ambiente são fontes de vida, porquanto a água que nos abastece é proveniente de corpos d'água das mais distintas origens.

Desta forma, o resultado esperado é uma contribuição na infraestrutura que identifique pontos e caminhos críticos no sistema de esgoto da Marinha do Brasil, seja na gestão administrativa, seja nas questões técnicas, pois implementar a preservação do meio ambiente em tempos pós-modernos é aplicar tecnologias ao menor custo, de forma concomitante ao bom desempenho de um sistema de esgoto que produza a satisfação da demanda dos usuários juntamente com a qualidade do descarte no meio ambiente para o exercício da função protetiva, com prevenção e precaução. Além disso, o presente estudo pode ser aproveitado por outros órgãos públicos com problemas similares, de forma a minorar as interferências no meio ambiente em nível orgânico, em todas as áreas da administração pública.

\section{5}

\section{Metodologia}

Com o objetivo de efetuar uma análise das condições atuais do sistema de esgoto da Marinha do Brasil, foram efetuados levantamentos de dados da situação existente nas Organizações Militares por meio de seus Planos Diretores, licitações executadas e fiscalizações de obras em andamento ou já concluídas, cujos dados foram coletados junto à Diretoria de Obras Civis da Marinha, órgão responsável pelas obras e projetos de grande vulto na Marinha do Brasil.

Para a avaliação do sistema de esgoto foram consideradas todas as etapas que contribuem para o desempenho do sistema, abrangendo, assim, desde a concepção gerencial da Administração, relacionada com a fonte de recursos; a concepção de gestão de projetos, abarcando a arte de projetar e a compatibilização entre os projetos, com o fim de eliminar erros durante a etapa da construção; a 
ótica da sustentabilidade e implementação de normas no âmbito dos licenciamentos ambientais e o descarte dos efluentes até a estrutura que se idealiza para uma modernização do sistema de esgoto.

Esta visão sistêmica é importante no momento em que o conjunto de todas as etapas formam um todo consistente e multidimensional, sendo certo que cada etapa, embora considerada para estudo de forma individual e independente da etapa que a sucede, insere-se numa sequência lógica entre as partes intermediárias, etapas estas que são necessárias para a obtenção de um sistema de esgoto com bom desempenho e em plena compatibilidade com o meio ambiente.

Desta forma, o presente estudo utiliza a pesquisa de campo como técnica de pesquisa, alinhado com o levantamento teórico correlato, a fim de buscar um resultado que atenda as necessidades apresentadas de modernização do sistema de esgoto da Marinha do Brasil. 


\section{GESTÃO DO SISTEMA DE ESGOTO: adequando a concepção e a execução}

\section{1}

\section{Considerações Iniciais}

Gerir uma instituição de grande porte é uma tarefa árdua e hoje a gestão requer o uso de técnicas que otimizem o desempenho de todos os processos, que devem ser identificados e coordenados, de forma a mitigar todas as interferências que diminuam a sua eficiência. A gestão de processos, segundo o Ministério do Planejamento - Gespublica (2010) é o instrumento que orienta a modelagem e a gestão de processos voltados ao alcance de resultados. A descrição envolve a reflexão acerca de características de validade dos produtos e serviços prestados, de referências (normas e conhecimentos) observadas, de recursos consumidos e dos insumos necessários à tomada de decisão com qualidade pelas pessoas e pelas instituições públicas. Com esse conceito adaptado à presente pesquisa, busca-se identificar quais são os problemas existentes, por meio de análise da estrutura do sistema de esgoto, quais são as boas práticas utilizadas e o impacto do desempenho deste todo sobre a organização.

Em constante busca por um melhor desempenho, a Diretoria de Obras Civis da Marinha (DOCM) foi reconhecida no ano de 2015 com o prêmio excelência pelo constante aprimoramento das práticas de gestão, dentre elas a criação e monitoramento dos níveis de atendimento ao cliente e o estabelecimento de parcerias para a fiscalização e análise de projetos e orçamentos.

Esta Organização Militar é responsável pelos projetos de engenharia de grande vulto na Marinha do Brasil, como é o caso do Programa de desenvolvimento de Submarinos Nucleares (PROSUB), figura 2.1, com a gerência dos projetos e físcalização na área da construção civil, que ainda se encontra em plena execução. 


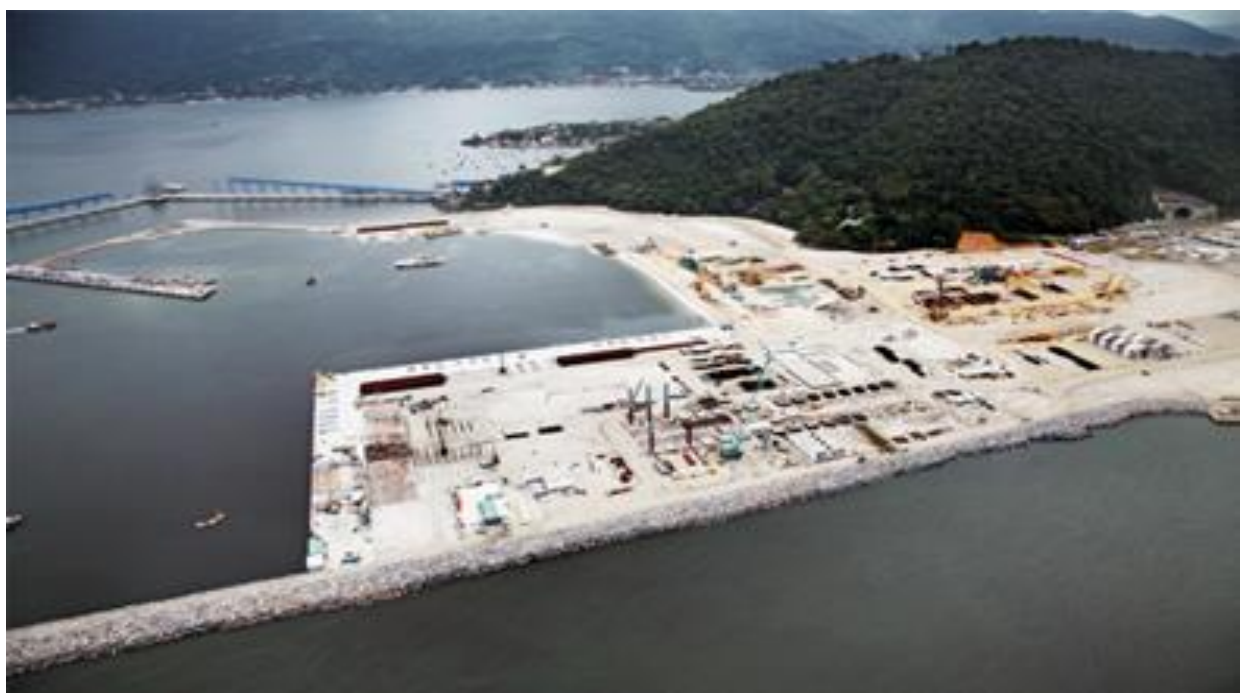

Figura 2.1: Construção dos Estaleiros e Base Naval da Marinha. Fonte: www.mar.mil.br.

Um grande desafio da Marinha do Brasil é conjugar o exercício de sua missão constitucional, estabelecida no art. 142, da Constituição da República Federativa do Brasil (BRASIL, 1988), e consequentes tarefas, com a otimização dos seus recursos, de forma a viabilizar tanto a implementação das normas em vigor quanto a manutenção da qualidade dos serviços públicos prestados.

E implementar de forma contemporânea as normas ambientais é manter a excelência na preservação do meio ambiente, objetivando a melhoria do desempenho do sistema, no caso, do sistema de esgoto, o que requer planejamento com revisões e adaptações de acordo com cada circunstância, já que não se pode tratar coisas distintas da mesma forma.

A gestão do sistema de esgoto envolve, pois, desde o processo decisório abrangendo a destinação dos recursos para cada organização militar, o controle da execução dos projetos e obras, até a adequação da adoção das técnicas de engenharia que melhor se adaptem ao caso concreto.

Para bem compreender todo o sistema de esgoto, também é necessário que se entenda a sua complexidade técnica, ou seja, o que este contém, cuja definição adotada é a de FERNANDES (1997, p. 35).

Para que sejam esgotadas com rapidez e segurança as águas residuárias indesejáveis, faz-se necessário a construção de um conjunto estrutural que compreende canalizações coletoras funcionando por gravidade, unidades de tratamento e de recalque quando imprescindíveis, obras de transporte e de lançamento final, além de uma série de órgãos acessórios indispensáveis para que o sistema funcione e seja operado com eficiência. Esse conjunto de obras para coletar, transportar, tratar e dar o destino final adequado às vazões de esgotos, compõem o que se denomina de Sistema de Esgotos. 
Para estes elementos componentes, há de se efetuar um sobrevoo amplo, no intuito de buscar uma visão sistêmica, desde a análise do histórico e levantamento do estado físico da situação existente do sistema de esgoto na Marinha do Brasil; a discussão sobre a análise da dispensa do licenciamento ambiental em empreendimentos militares de emprego de força e preparo pelo órgão ambiental, com o fim de otimizar a missão institucional; a necessidade de modernização e revitalização do sistema, enfim, efetuar uma análise dos dados colhidos porquanto a melhoria do desempenho abrange todas estas etapas que somadas melhoram o desempenho de todo o sistema.

\section{2}

\section{Desafios na Gestão}

Além dos meios navais, que são os navios de guerra, na Marinha do Brasil existem as edificações terrestres, local de apoio às operações navais e onde se estabelece grande parte dos militares. Este apoio logístico no âmbito militar é de importância fundamental para o êxito da missão, pois, em tempos de paz, nas instalações terrestres ocorrem treinamentos e desenvolvem-se programas de preparo do pessoal, além de alocarem todo o apoio administrativo dos diversos setores do conhecimento, tais como a contabilidade, advocacia, engenharia, tecnologia da informação, medicina e farmácia.

Não é tão simples definir os pontos de apoio terrestres para a tripulação durante a época de paz, e tal tarefa requer zelo e atenção, pois é nesta época que se executam os treinamentos e desenvolvem-se os serviços administrativos, com o uso da infraestrutura disponível.

Para tanto, deve-se prover um nível adequado de conforto e segurança, pois existe uma rotina diferenciada de expediente de trabalho, na qual necessita-se que muitos militares pernoitem no quartel, com rotatividade neste horário, em face da vigilância permanente nos quartéis, além de ocorrer uma utilização diferenciada em decorrência do seu uso em horários de pico, como nos alojamentos.

São centenas de edificações tombadas com destinação exclusiva para o uso da Marinha do Brasil, que existem dentro de diversos Complexos Navais. E nestas edificações existem sistemas de esgotos dotados de longa data, já que a Marinha 
do Brasil surgiu em 1822, com a missão de prover a defesa do mar territorial, utilizando-se de instalações terrestres para apoiar suas tarefas desde então, como verifica-se no Serviço de Documentação da Marinha (2004).

Nossa força naval, pois, foi necessária para concretizar a nossa Independência e levar a todos os recantos do litoral brasileiro a notícia do dia 7 de setembro de 1822, utilizada para fazer frente aos focos de resistência à nova ordem. É importante lembrar que a missão da Marinha do Brasil (MARINHA, 2015) é preparar e empregar o Poder Naval, a fim de contribuir para a defesa da Pátria; estar pronta para atuar na garantia dos poderes constitucionais e, por iniciativa de qualquer destes, da lei e da ordem; atuar em ações sob a égide de organismos internacionais e em apoio à política externa do País; e cumprir as atribuições subsidiárias previstas em Lei, com ênfase naquelas relacionadas à Autoridade Marítima, a fim de contribuir para a salvaguarda dos interesses nacionais. Isso demonstra que, embora seja de grande importância a manutenção das organizações militares terrestres, a manutenção dos meios marítimos devem ser a principal finalidade desta instituição.

A Marinha do Brasil, segundo dados extraídos do organograma disponível digitalmente pela MARINHA (2015), é composta de: 9 (nove) Distritos Navais, 7 (sete) Capitanias dos Portos. 22 (vinte e duas) Agências, 15 (quinze) Delegacias, e 7 (sete) Bases Navais. Além destes, existem outros órgãos de apoio específicos, como as 4 (quatro) Escolas de Formação, os 3 (três) Centros de Instrução e todos os outros quartéis que compõem a Marinha do Brasil em apoio terrestre, que totalizam, aproximadamente, 280 unidades militares.

Todos estes órgãos militares são compostos de diversas edificações, para uso e apoio das inúmeras tarefas atribuídas à Marinha do Brasil, o que representam muito mais que 280, já que para cada denominação de Organização Militar, nem sempre há uma correspondência de apenas uma edificação.

Na Diretoria de Obras Civis da Marinha, quartel que tem a missão de licitar projetos e obras de grande porte, como previsto no seu Regimento Interno e na publicação DGMM-0600 (Normas de procedimento técnico-administrativo para o processo de obtenção de instalações terrestres através de execução de obras civis), no ano de 2014 foram executadas, no máximo, 3 (três) licitações para a reforma, ampliação ou construção do sistema de esgoto para todo o Brasil. Neste ano de 2015 já foram mais de 20 análises de projetos neste sentido. Entretanto, 
nenhuma licitação de grande vulto ocorreu até meados do ano de 2015 naquela OM. E provavelmente não ocorrerão mais, tenho em vista o corte orçamentário de grande impacto negativo que tem feito com que a Marinha do Brasil revise todos os seus gastos, de forma a retrair todos os custos com contratações de terceiros.

Estes números não computam as licitações de projetos e instalações de pequena monta, procedimentos estes que são executados nos próprios quartéis, nem as licitações que ocorrem diretamente nas Organizações Militares. Entretanto, considerando o número total de licitações por todo o Brasil, percebese que ainda há poucas licitações diante da necessidade de modernização de todo o sistema de esgoto.

Por ano, a Diretoria de Obras Civis da Marinha efetua, em média, 10 (dez) análises de projetos de grande vulto relacionados com o sistema de esgoto da Marinha do Brasil, que são recebidos para serem analisados à luz das normas técnicas vigentes, cujo objeto seja a construção, reforma ou ampliação de alguma parte do sistema de esgoto, destacando-se projetos que já se encontram em execução física ou em licitação e que fazem parte de um importante programa de proteção ao meio ambiente: o programa de despoluição da Baía de Guanabara. Este assunto será discorrido no Capítulo 5, do presente trabalho.

Diante de tantas instalações existentes, a Administração Naval envida os seus melhores esforços para garantir a sua manutenção e funcionamento. Entretanto, limitada pelos recursos orçamentários destinados às obras civis, tem atendido menos do que o necessário, o que afeta o desempenho dos sistemas, tanto pela diminuição da terceirização para a manutenção, quanto pela pequena quantidade de pessoas para garantir uma fiscalização eficiente, afetando a gestão do projeto e da própria execução da obra.

É importante frisar que apesar das dificuldades a meta não pode ser deixada de lado, ou seja, preservar a melhor técnica nos projetos e obras é imprescindível para que ocorra a modernização do sistema de esgoto. Assim, devem os projetos considerar a necessidade de substituir o sistema fossa-filtro nas organizações militares existentes por um sistema mais eficaz, e proceder a ligação ao tronco coletor ou construir ETE’s nas construções novas. E diferente forma não poderia ocorrer já que a modernização somente ocorrerá se iniciar-se as mudanças desde já. 
Os dados orçamentários contidos nas Leis de Orçamento Anual (LOA) refletem a questão da limitação de uma forma muito clara, quando se percebe a evolução da aplicação dos recursos na área de despesas de capital, do tipo investimento, área que abrange ações várias, dentre elas as obras de reforma e manutenção das organizações militares terrestres, como pode ser visto na norma que rege o direito financeiro, art. $12, \S 4^{\circ}$, da Lei $n^{\circ} 4.320$ (BRASIL, 1964), que estatui normas gerais de Direito Financeiro para elaboração e controle dos orçamentos e balanços da União, dos Estados, dos Municípios e do Distrito Federal.

$\S 4^{\circ}$ Classificam-se como investimentos as dotações para o planejamento e a execução de obras, inclusive as destinadas à aquisição de imóveis considerados necessários à realização destas últimas, bem como para os programas especiais de trabalho, aquisição de instalações, equipamentos e material permanente e constituição ou aumento do capital de empresas que não sejam de caráter comercial ou financeiro.

Por meio da análise do levantamento da situação dos últimos 5 (cinco) anos, verifica-se que os repasses da União não são condizentes com a necessidade da Marinha do Brasil, tendo sido reduzido drasticamente neste ano de 2015, de acordo com a análise do valor contido no Anexo IV e previsto no inciso IV, art. 10, todos dispostos na Lei $\mathrm{n}^{\circ} 13.115$ (BRASIL, 2015), conhecida como LOA 2015. Veja-se a tabela 2.1:

Tabela 2.1: Valores de investimento para a Marinha do Brasil, conforme Lei Orçamentária Anual (LOA 2015).

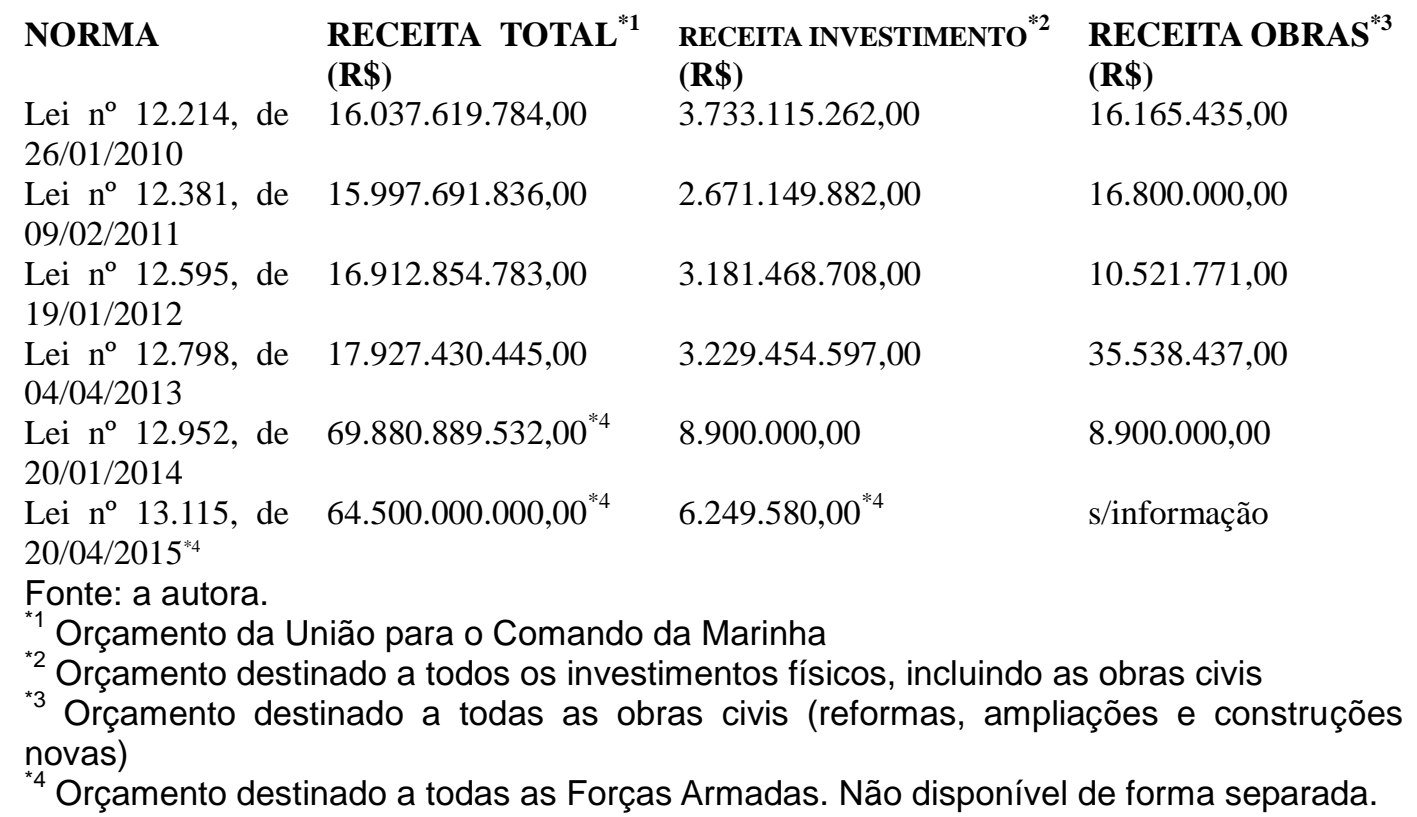


Distribuindo-se os dados levantados em forma gráfica pode-se analisar a evolução dos valores de receita da União, o que demonstra claramente a redução reiterada das receitas para a Marinha do Brasil, conforme se verifica na figura 2.2 que se segue.

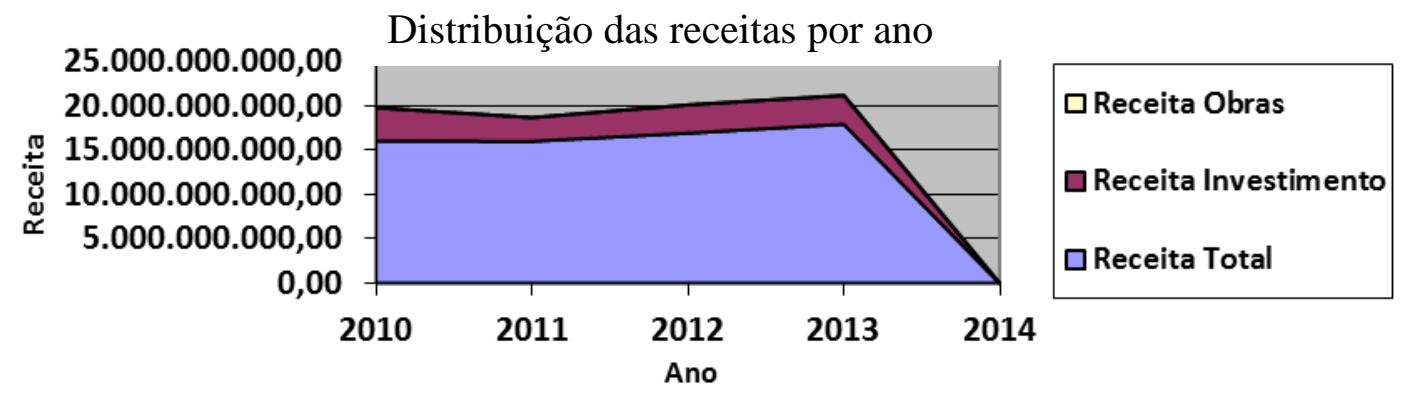

Figura 2.2: Distribuição das receitas da União para obras $x$ ano. Fonte: a autora.

Os valores destinados para a manutenção e acréscimo de unidades terrestres equivaler, em média, a $1 \%$ do valor destinado para os investimentos físicos. Este valor representa um valor muito abaixo das necessidades reais. Por exemplo, no ano de 2012 o valor para reformar, manter, construir e acrescer os, aproximadamente, 280 quartéis em toda a Marinha do Brasil foi de $\mathrm{R} \$$ 10.521.771,00. Ora, se dividir este valor pela quantidade de quartéis tem-se o irrisório valor de $\mathrm{R} \$ 37.578,00$ por quartel, sendo a denominação quartel aqui equivalente a dizer complexo de edificações, o que diminui ainda mais o valor por edificação. Isso sem contar que esta verba inclui a destinação para a construção de novas edificações.

A situação de disponibilidade de recursos é realmente abaixo do desejável e a Marinha do Brasil precisa usar de todas as suas técnicas de planejamento para otimizar os recursos da melhor forma possível, sendo certo que priorizar a meta de modernização do sistema de esgoto ultrapassa a questão de gerir recursos, mas vai ao encontro da necessidade de atendimento das normas técnicas e ambientais.

Muitas redes estão desativadas e outras não estão mais em uso, situação que também compromete a adequação entre a concepção dos projetos e a execução das obras, já que ocorre a perda do controle da localização das tubulações e dispositivos, que surgem como intercorrências na gestão e comprometem o bom resultado do desempenho esperado. 
Essa situação pode ser corrigida com um levantamento georeferenciado, que manterá não somente um arquivo atualizado, mas também impedirá a ocorrência de erros de projeto no que tange à interferência de outra rede, identificada por meio do citado levantamento. Este serviço é de fácil disponibilidade. Um exemplo de levantamento do sistema de esgoto e demais redes por meio do sistema de georeferenciamento pode ser citado. Segundo a empresa CONEN- Consultoria e Engenharia (CONEN, 2016), com este sistema é possível ocorrer a localização precisa de todas as tubulações e dispositivos dos sistemas e redes, o que permite a precisão nos futuros projetos, a adequada manutenção e execução de construções no entorno, o que elimina os erros de projetos e execução de obras.

\section{3}

\section{Estrutura Atual do Sistema de Esgoto}

A contribuição dos efluentes do esgoto dos quartéis da Marinha do Brasil é de extrema relevância, pois se trata de operação de descarga para o meio ambiente de um grande volume de águas residuais gerado pelos usuários. Diante desta quantidade de efluente, há de se observar a necessidade de um bom desempenho do sistema de esgoto, minimizando-se ao máximo os impactos no meio ambiente. E essa minimização depende da modernização do sistema que, por sua vez, requer recursos orçamentários da União.

A modernização não somente requer atenção especial para todos os aspectos da engenharia, mas também para os aspectos ambientais, administrativos e políticos, pois ao elaborar os projetos de esgoto todos estes aspectos irão influenciar diretamente na contratação dos terceirizados e no próprio projeto de engenharia, especialmente no que concerne à localização das edificações, tipo de coleta e tratamento e lançamento dos equipamentos e tubulações sanitários.

No Brasil, os efluentes deveriam ser coletados e tratados por uma rede pública de qualidade, para tornar efetiva a destinação dos líquidos no retorno à natureza e garantir, assim, a proteção ambiental e o seu reuso pelas gerações futuras. Entretanto, tratando-se de um elemento da infraestrutura urbana, que assim como em qualquer órgão público é limitada pelos recursos públicos, o sistema de esgoto se submete, pois, a uma relação direta com as questões políticas 
e geográficas já que, historicamente, muitos projetos foram definidos e não concluídos, sendo que no mandato seguinte algumas construções eram, até mesmo, desfeitas. Esta conduta política de ineficiência nos resultados deve ser superada, pois é um obstáculo vicioso que deve ser removido, como se observa (FREITAS, 2011, p. 203-209):

Vícios políticos, por definição, são todos os desvirtuamentos ou disfunções que afastam a política da prática continuada da gestão favorável ao bem de todos, de modo responsivo. Desse modo, em lugar da arte de governar democraticamente ou de conduzir os destinos em parceria (tarefa útil e inescapável), a política viciada pela insaciabilidade patológica passa a ser o exercício da dominação carismática ou de qualquer outro tipo de subjugação... A insustentável teoria do imediato radica no culto do poder pelo poder.

E estes vícios não se manifestam somente no âmbito de saneamento, mas também em outras áreas de serviços essenciais, e se repetem no âmbito de gestões administrativas de diferentes órgãos públicos. Tais condutas devem ser rechaçadas de pronto e os profissionais comprometidos com os projetos e execuções das obras, especialmente como seus fiscais, devem ser conscientes de que precisam cooperar com a sociedade, subsidiando os gestores com argumentos técnicos suficientemente concretos para que consigam formar e reformar as suas opiniões em prol da eficiência da Administração Pública, atendendo um dispositivo legal previsto no art. 37, da Constituição da República Federativa do Brasil (BRASIL, 1988).

Os aspectos geográficos também contribuem com alguns pontos negativos no crescimento da contaminação das massas d'água, tal como a facilidade de acesso direto aos canais e as construções irregulares ao longo destes lugares, como indicado na figura 2.3. Obviamente não se subtrai desta ótica as políticas públicas implantadas, mas que não são objeto da presente pesquisa, pelo que se coloca apenas uma breve reflexão sobre as construções de quartéis ao largo de córregos e rios, que devem ser geridas com responsabilidade e profissionalismo, de forma que sejam revistas periodicamente para que sejam modernizadas e adequadas com a atual função protetiva do meio ambiente, que é responsabilidade legal de todos os cidadãos, garantindo assim a sua existência sustentável e o seu bom desempenho. 


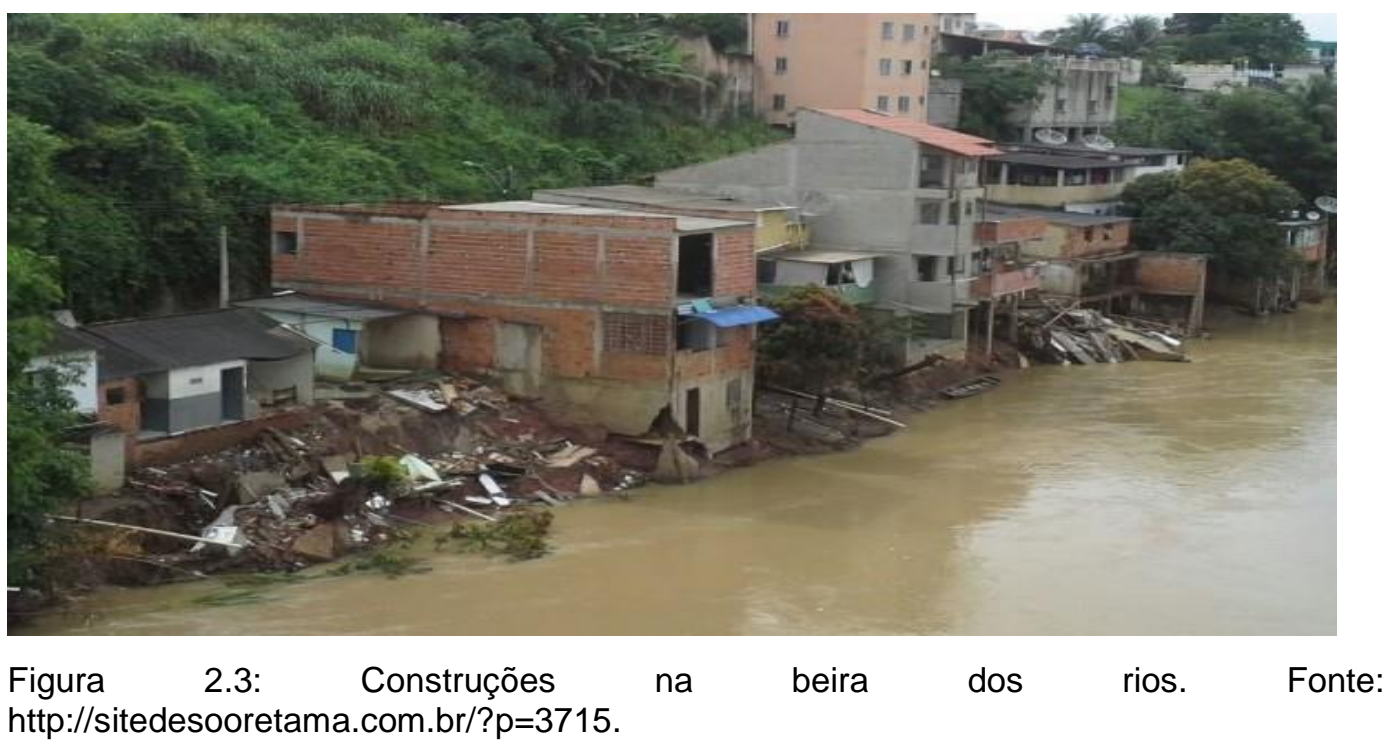

Outrossim, a manutenção e construção, o dimensionamento e o tratamento de uma rede de esgoto, ao considerar os aspectos atuais de preservação do meio ambiente, para a atual e para as próximas gerações, deve visar a saúde da população, reconhecendo a limitação dos recursos hídricos e da sua autodepuração, bem como a proteção e manutenção do sistema de recepção, como rios e oceanos, tudo devidamente previsto no art. 225, da Constituição da República Federativa do Brasil (BRASIL, 1988). A importância de efetuar um projeto adequado e garantir uma boa gestão durante a execução da obra, de forma a propor a maior eficiência no resultado é, pois, uma forma de melhoria para o meio ambiente com o uso da engenharia.

E esta assertiva leva a uma reflexão mais profunda sobre a questão da estrutura entregue pelo Governo, como cita NETTO (1998, p. 506):

A implantação de um sistema público de abastecimento de água gera a necessidade de coleta, afastamento e disposição final das águas servidas, sendo esses últimos aspectos, juntamente com o primeiro, serviços de infra-estrutura indispensáveis a toda comunidade civilizada. Nas cidades beneficiadas por um sistema público de abastecimento de água e ainda carentes de sistemas de esgoto sanitário, as águas servidas acabam poluindo o solo, contaminando as águas superficiais e freáticas e frequentemente passam a escoar pelas valas e sarjetas, constituindo-se em perigosos focos de disseminação de doenças.

Uma dificuldade que também deve ser levada em consideração nas construções dos quartéis da Marinha do Brasil é a preexistência de construções de idades muito antigas, cujas redes interferem em muito na execução das novas 
edificações e, principalmente na reforma das existentes, atingindo tanto o momento da concepção do projeto quanto da execução as obras.

A Secretaria D’Estado dos Negócios da Marinha foi criada em 28 de julho de 1736, pelo ainda Rei de Portugal, como informa a MARINHA (2015), e foi reorganizada por D. João VI quando da sua chegada ao Brasil em 1808, ocasião em que foi nomeado para a pasta do então Ministério da Marinha e Domínios Ultramarinos o antigo detentor do cargo, D. João Rodrigues de Sá e Menezes - Conde de Anádia, considerado dessa forma como o nosso primeiro Ministro da Marinha. Para as operações de guerra, a partir de então, era necessário o apoio terrestre, e surgem construções para o apoio de pessoal, que vem se expandindo desde então, com as suas diversas tarefas como desenvolvimento de treinamentos, cursos, apoio logístico, estoque e abastecimento, dentre outras. Observa-se, então, que a idade das edificações influenciam muito, posto que a sua manutenção tem que adequar-se aos limites financeiros e necessidades de modernização.

Após efetuar um levantamento conjugando os dados obtidos no organograma da MARINHA (2015) e demais informações ali disponíveis, obtevese um mapeamento da idade média da construção dos quartéis. Nele, é possível vislumbrar a dificuldade de manutenção das edificações e, consequentemente, do sistema de coleta e destinação dos efluentes gerados nas mesmas, pois existem edificações que datam até mesmo do início de 1800, dentre outras datas tão distantes, percebendo-se a importância da manutenção periódica do sistema, com reformas e ampliações que façam o devido ajuste à real demanda existente.

Veja-se a distribuição das construções das edificações de organizações militares por ano, conforme figura 2.4, cujos dados foram obtidos junto às Organizações Militares: 


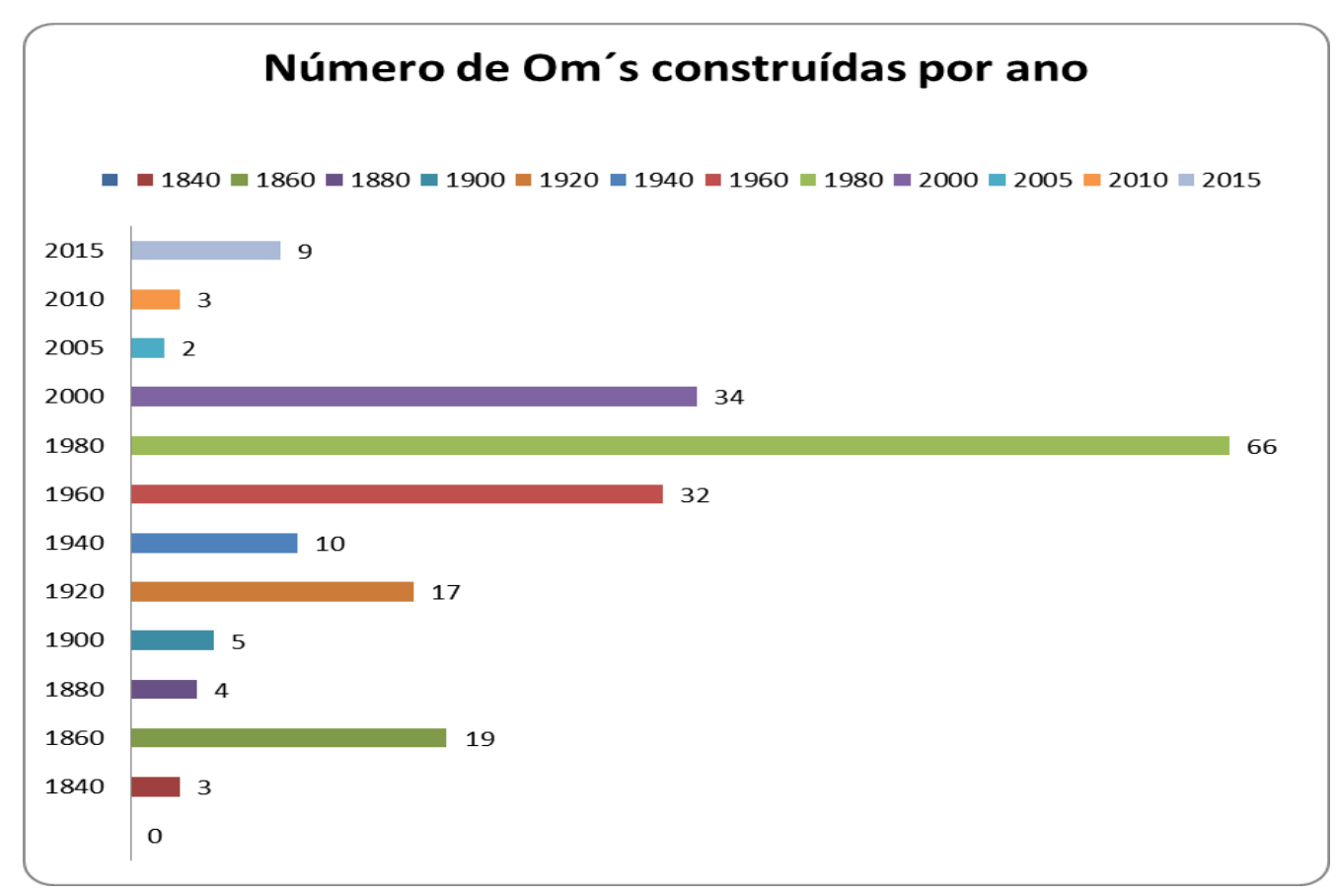

Figura 2.4: número de OM’s construídas $\mathrm{x}$ ano de criação. Fonte: a autora.

Tudo isso retrata a importância de um correto levantamento, abrangendo os dados históricos locais, a busca de redes ao longo do terreno, ainda que não haja registros das mesmas, a verificação do estado dos resíduos que estão sendo lançados no meio ambiente ou na rede de esgoto pública, enfim, do mais pleno conhecimento da coleta, do percurso e da distribuição de todas as águas residuais que advém das edificações dos quartéis da Marinha do Brasil, requerendo uma especial atenção a gestão dos projetos para o bom desempenho do sistema de esgoto que, em última análise, deve evitar os retrabalhos e racionalizar os custos dos projetos e da execução das respectivas obras. E se preocupar-se com o dimensionamento do sistema é algo importante, também o é preocupar-se com as interferências externas que impactarão o desempenho do sistema como o caso de interferência das redes pré-existentes ou de má compatibilização dos projetos.

Todos os 280 órgãos militares são compostos de diversas edificações, para uso e apoio das inúmeras tarefas atribuídas à Marinha do Brasil, que se encontram cadastrados como tombos na Diretoria de Administração da Marinha. A Marinha do Brasil dispões de um rigoroso cadastro imobiliário, de forma a planejar, acompanhar e controlar o patrimônio imobiliário da Marinha. Este controle é lançado em um sistema computadorizado denominado CADIMAweb, disponível por meio de cadastro prévio junto àquele órgão. 


\section{4}

\section{As Interferências e a Gestão com Qualidade}

$\mathrm{Na}$ execução do projeto nem sempre as coisas acontecem como foram previstas. Mesmo buscando os dados existentes da área, como histórico de obras e levantando o local, fica difícil prever que exista alguma tubulação enterrada que já tenha sido, por exemplo, desativada. Ou que o encaminhamento de uma tubulação não está de acordo com as plantas de acordo com o construído ("as built"), entregue após o término de uma obra e devidamente arquivada no quartel.

A despeito de investigar caixas de inspeção e aberturas por espias, ainda sim é de difícil observância, especialmente nos casos de edificações muito próximas umas das outras, o que tem se tornado muito comum nos quartéis da Marinha do Brasil, já que tem aumentado as suas necessidades administrativas e de apoio logístico, sem o aumento da área física disponível para as construções das novas edificações ou, até mesmo, sem possibilidade de ampliação das antigas instalações existentes.

Casos de redes elétricas enterradas, bem como as demais redes, como de água e passagem de redes de computadores, também estão inclusos na lista de interferências durante a execução das obras causadas por redes pré-existentes. Portanto, o problema não se limita às redes de esgoto e é muito mais sério do que se pode imaginar. Os atrasos nas entregas, as diversas alterações contratuais, sem contar o aumento de necessidade de recursos, são consequências indesejáveis e que podem influenciar no desempenho do sistema de esgoto, no sentido de que passam a causar grande confusão administrativa, em detrimento da própria execução técnica, diminuindo a eficiência do sistema.

Além disso, erros de execução durante as obras, por falta de observância da ordem entre as redes e estrutura são muito comuns. MACINTYRE (2012, p. 32) cita a possibilidade de existência de uma previsão de passagem de tubulação em lajes ou qualquer outra peça estrutural e de um erro muito comum: a concretagem executada juntamente com a tubulação, deixando ambas em um corpo único, o que danificará a tubulação que não é projetada para resistir aos movimentos e cargas a que a estrutura se submete, causando rompimento da tubulação ou mesmo de uma conexão que seja adjacente à esta tubulação. 
Deve-se fazer a correta proteção e limitação deste espaço. Como solução, o autor revela que, se for impossível impedir a concretagem com o tubo, que ao menos coloque-se uma tubulação de água, classe K9, para que se minimize o risco de rompimento.

Outra situação de erro é a inexistência da previsão de passagem da tubulação, ou seja, ao preparar o espaço de concretagem não se coloca na forma a previsão da passagem da tubulação. Este é o pior dos problemas, porque exigirá a passagem de forma externa, já que nunca se deve quebrar um elemento estrutural, pois afetará a sua resistência, alterando o caminhamento das cargas e, possível sobrecarga em outro elemento estrutural. E o pior é que alguns empreiteiros não atentam para esta forma de correção e insistem em abrir um buraco dentro do elemento estrutural, comprometendo toda a edificação com a sobrecarga causada pela redistribuição das cargas, implicando em exposição a acidentes de incontestável gravidade. Sem contar a situação de onerosidade criada pelo atraso na entrega do objeto contratado e o aumento de custos pelo refazimento dos serviços.

Também é importante a observação da área de cobrimento, pois grande parte das obras da Marinha do Brasil são em áreas de grande agressividade, porquanto estão próximas do mar. Assim, o cobrimento mal executado ou subdimensionado exporá as ferragens, causando dano estrutural, como pode-se verificar na figura 2.5.

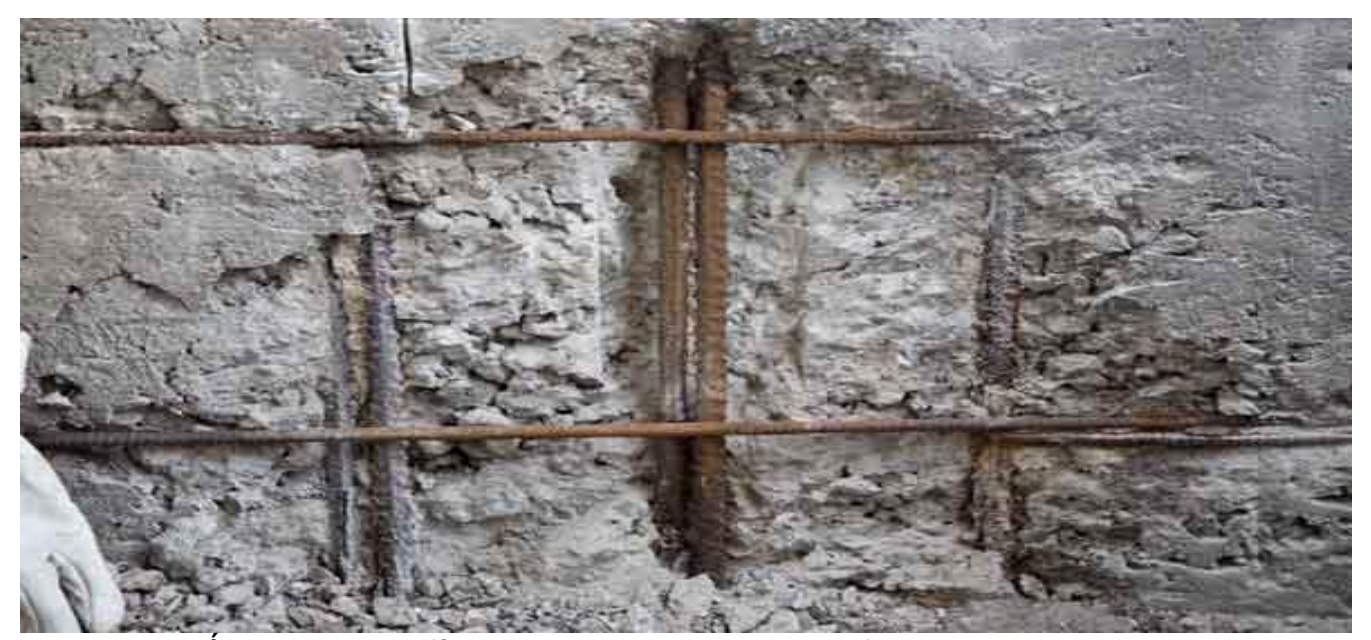

Figura 2.5: Área de superfície com recobrimento insuficiente e mal executado. Fonte: a autora. 
Quando se tratar de tubulação enterrada, também é necessária a atenção ao recobrimento. Então, ao enterrar as canalizações, deve-se verificar e prever a que tipo de esforço estará submetida, o que quer dizer que, como citado por MACINTYRE (2012, p.132), quando a canalização estiver enterrada deve-se atender a uma profundidade que seja possível absorver os choques e vibrações provocados na superfície. Neste caso, o autor recomenda o uso de ferro fundido, com revestimento adequado, sendo possível a utilização de manilhas de cerâmica vidrada, desde que envolvidas de em camada de concreto e espessas o suficiente para resistir aos esforços.

Então, ao projetar, não é possível esquecer de consultar o arquiteto que projetou a área urbanizada do entorno, para conhecer os esforços sobre o solo e a necessidade de aumentar a profundidade ou reforçar a superfície para não impactar as caixas de inspeção e os poços de visita.

A norma técnica NBR 8160 (ABNT, 1999), apreensiva com os erros de execução, listou em seu Anexo $\underline{E}$, alguns procedimentos e cuidados que devem ser tomados quando da execução dos sistemas prediais de esgoto sanitário. Além disso, inseriu no seu Anexo $\underline{G}$ os procedimentos de ensaios de recebimento do sistema. Este é um roteiro mínimo que deve ser observado por qualquer engenheiro da obra. Transcreve-se, parcialmente, o discorrido:

\begin{abstract}
6 Execução
Os sistemas prediais de esgoto sanitário devem ser executados de acordo com o projeto, de forma a garantir o atendimento aos requisitos de desempenho conforme 4.2. No anexo E são apresentados alguns procedimentos e cuidados a serem tomados quando da execução dos sistemas prediais de esgoto sanitário. No anexo $G$ são apresentados os procedimentos de ensaios de recebimento do sistema. As tubulações aparentes do sistema predial de esgoto sanitário devem ser pintadas conforme a NBR 6493.
\end{abstract}

Outra dificuldade que gera erros na construção ocorre na fase anterior à própria obra. Quando a própria Administração Naval não possui meios de executar os projetos necessita efetuar uma licitação para a contratação de uma empresa que preste este serviço de engenharia. $\mathrm{Na}$ fase de recebimento do projeto contratado, ou seja, no momento de aceitação de projeto é preciso que se verifique a compatibilização dos diversos projetos, ou seja, arquitetura, estrutura, instalações prediais, saneamento, elétrica, mecânica, enfim toda as especialidades 
que foram necessárias para a conclusão de todo o projeto. E este erro não ocorre na concepção, mas no momento posterior a esta e anterior à execução.

A situação mais comum é a o órgão militar executar a licitação para a obtenção de um projeto de engenharia, sendo que na consequente contratação não é possível decidir quais são os projetistas e como será o procedimento da execução do projeto, pois o que se pode contratar é a compra de um projeto. Obviamente a qualidade está intrínseca ao produto entregue, mas não é possível se avançar no modus operandi da empresa. Ao receber o produto, é certo que será feita uma análise dos projetos, mas de atendimento de requisitos básicos, mas não a análise da qualidade técnica, que é de responsabilidade da contratada. Até porque, os fiscais do contrato, em regra, nem sempre são técnicos, cabendo uma análise mais de bom senso do que propriamente de conteúdo e compatibilização dos projetos entre si.

A importância da gerência eficiente de projeto é uma situação que fará toda a diferença na futura execução da obra. Segundo JUNIOR (2014, p. 237):

Tendo em vista que muitos dos problemas relacionados á falta de qualidade em edificações, tem como causa principal um processo de projeto informal, setores da construção civil têm buscado, ainda de forma principiante, metodologias de gestão da atividade de projeto, no sentido de modificar, melhorar e aperfeiçoar o modelo convencional e garantir a qualidade de seus produtos e processos, tendo como principais consequências um produto final de qualidade e satisfação do cliente.

Onde a fase de projeto desempenha fator determinante em um empreendimento de construção civil, pois possibilita o mapeamento das probabilidades pré-execução, melhoramentos de métodos de execução, interferências e possíveis patologias decorrentes, auxiliando na detecção de problemas e assim reduzindo o índice de desperdícios e retrabalhos, aumentando ganhos financeiros durante sua construção.

Espera-se que a obra executada atenda a todos os requisitos esperados de conforto, aparência, térmico, e que todos os equipamentos atendam a finalidade a que se destinam. Na prática, há verdadeira segregação entre o projetista e o executor, ainda mais quando ocorrem mudanças de projeto que, por vezes, chegam ao canteiro de obras após a execução, ou seja, quando o problema já está implementado.

Por outras vezes, as mudanças se passam de forma a atender as exigências ou situações supervenientes externas que influenciam a decisão tanto do construtor quanto do cliente, o que se dá, em regra, sem a empresa projetista 
contratada, mas com a empresa construtora contratada, já em outro processo licitatório.

Ou seja, fica-se longe da responsabilização do projetista contratado quando, em muitas das situações existentes, o que ocorreu foi a imprevisão decorrente da negligência ou imperícia do técnico projetista. O que se busca é a solução imediata, e paralisar a execução para aguardar a correção do projeto pelo projetista inicial representa, em regra, a perda dos recursos para a própria execução da obra.

Segundo JUNIOR (2014, p.245), é importante que as responsabilidades sejam definidas e exercidas de fato, pois que não é possível economizar no custo da compatibilização do projeto e gerar grandes despesas quando da execução da obra, o principal produto esperado. Com esta meta, apresenta-se a tabela 2.2, como uma relação entre as responsabilidades do projetista e as responsabilidades dos clientes.

Tabela 2.2: Responsabilidades Projetista x cliente. Fonte: JUNIOR, 2014, p. 3244.

\section{Item Responsabilidade do projetista \\ Responsabilidade do cliente}

1 Descomprometimento com a interação

Fornecimento de informações incompletas e incorretas como embasamento para o desenvolvimento do projeto

2 Pouco conhecimento com as técnicas Falta e componente capacitado construtivas da obra para análise técnica dos diversos projetos e tomadas de decisões

3 Falta de interesse e ausência de conhecimento sobre os demais projetos

Postergação de decisões que influenciam no desenvolvimento dos projetos

Na Marinha do Brasil, a Diretoria de Obras Civis é o órgão responsável pela análise dos projetos contratados. Mas apenas para os projetos de grande porte e/ou complexidade, até porque não seria possível a implementação da análise de todos os projetos, pois não há engenheiros em número suficiente para atender a toda a demanda do país. Esta previsão está inscrita no item 1.3.1 - Diretrizes, do Capítulo 1 - Generalidades, da documentação interna naval denominada DGMM0600 (Normas de procedimento técnico-administrativo para o processo de obtenção de instalações terrestres através de execução de obras civis), disponibilizada pela MARINHA (2015). 
Veja-se o que diz a norma administrativa:

1.3.1 - Diretrizes

a) Os processos de obtenção de instalações terrestres e/ou reformas através da execução de obras civis, que envolvam investimentos de grande vulto e/ou complexidade, mesmo não contidos no Plano Básico "ECHO", serão desenvolvidos sob a supervisão técnica da Diretoria de Obras Civis da Marinha (DOCM).

d) A OM interessada deverá estabelecer as características básicas do empreendimento, tais como dimensões e instalações necessárias, de modo a possibilitar uma avaliação inicial do vulto e complexidade da obra, que permitam estimar o custo e o prazo da elaboração do projeto de engenharia e de execução das obras civis, a fim de subsidiar a elaboração do Projeto de Investimento, de acordo com o previsto nas Normas para Execução do Plano Diretor.

h) As avaliações e vistorias que forem necessárias à obtenção ou reformas de instalações terrestres, são da responsabilidade da DOCM, no âmbito da MB.

Portanto, a maioria dos acompanhamentos de pequenas obras de reformas e acréscimos é feita por pessoas da administração, mas que podem não ser especialistas no assunto, pois a grande maioria é considerada obra de pequeno vulto/complexidade, como demonstrado no gráfico de Distribuição de construções de organizações militares por ano, no item 1.1, da presente pesquisa.

No que concerne às decisões, é fato que as alterações de grande monta nos projetos necessitam ser emanadas pela organização interessada. Como as obras normalmente são de outros quartéis, é necessária a presença ou, ao menos uma reunião prévia, com o Comandante do quartel aonde ocorrerá a construção/reforma da edificação. Esta situação administrativa representa uma postergação de prazos, pois não possível atender a urgência necessária para uma decisão que demanda tantas fontes diferentes, com funções, conhecimentos e, por vezes, localidades diferentes e distantes e, até mesmo, de difícil acesso.

Inúmeros problemas podem ocorrer quando não há a compatibilização dos projetos. Um exemplo é a instalação de um tubo de queda aonde se localiza uma coluna. Outro exemplo é a passagem de tubulações dos ramais de esgoto na mesma cota das cintas, a passagem de uma rede de esgoto com uma viga no meio do caminho. Projetos de estrutura já executados sem a previsão das passagens, ou, ainda, sem a possibilidade mesmo da passagem da tubulação como, por exemplo, dentro de uma estaca. Tudo isso acarreta cortes desnecessários das ferragens dos pilares e vigas, gasto de tempo para efetuar as lajes por onde o tubo iria passar. E em todas as situações de erro de compatibilização de projeto é verificável o 
aumento de custos e retrabalhos infindáveis que geram termos aditivos contratuais junto às contratadas, fato este indesejado e que requer muita atenção com a gestão do erário público.

Por óbvio, a mudança do encaminhamento das tubulações interfere nas declividades, requisito importante para um bom funcionamento hidráulico do esgoto, o que também interfere nas pressões internas do sistema. Além disso, mudar o trajeto das tubulações também pode sofrer a interferência de outras redes ou causar alterações econômicas substanciais, especialmente se houver alteração de técnica ou impedimentos geológicos, do que pode surgir um aumento dos custos, indesejável, com certeza, e que pode inviabilizar a execução da obra a ponto de paralisá-la.

Os problemas são inúmeros e podem ser eliminados com a inclusão de mais uma etapa, tão importante quanto a anterior e a posterior: um gerenciamento eficiente que permita a compatibilização dos projetos e a sua análise de custos estimados, antes do recebimento definitivo do objeto contratado.

\section{5 \\ Procedimentos Propostos}

A gestão de qualidade tem sido uma preocupação da Administração Naval. Em relação aos recursos, existe um Conselho Consultivo subordinado ao EstadoMaior da Armada denominado Conselho do Plano Diretor (COPLAN), como disposto no organograma da MARINHA (2015).

O Plano Diretor da Marinha (PD) foi criado em 1963, na gestão do então Ministro da Marinha, Almirante-de-Esquadra Sylvio Motta. O PD passou por diversas reformulações, ao mesmo tempo em que procurou manter sua essência original, ao permitir a realização do planejamento, execução e controle dos objetivos da Marinha ao longo dos seus 50 anos de existência. Neste planejamento há um controle da existência física e dos custos de todo o processo, objetivando um acompanhamento físico-financeiro.

Segundo OLIVEIRA (2000, p.41-46), em sua dissertação apresentada à Escola Brasileira de Administração Pública da Fundação Getúlio Vargas, para a obtenção do grau de mestre em administração pública, sob o título $\mathrm{O}$ orçamento 
como instrumento de planejamento, execução e controle: estudo do caso do plano diretor da marinha do brasil, tem-se que:

O planejamento, na definição da Escola Superior de Guerra, "é a racionalização do processo de tomada de decisões"... Na etapa de elaboração de planos são formulados os planos governamentais de desenvolvimento e segurança, assim como são elaborados os orçamentos que fixam os recursos financeiros que permitem a implementação das ações neles contidas. Posteriormente, desenvolvem-se os estágios de coordenação e implantação, que compõem a etapa de execução.

OLIVEIRA (2000, p.46) inclui a ideia de que se preocupar com os detalhes do planejamento é estabelecer a missão, os objetivos, a políticas e os valores que orientam a alocação dos recursos organizacionais e o alcance de metas traçadas. E acrescenta:

Neste processo, continuamente são analisadas as forças e fraquezas do ambiente interno, bem como as oportunidades e ameaças existentes na ambiência externa. É um modelo que se desenvolve mediante um processo decisório racional, em que as atividades organizacionais são concebidas tendo em vista o atingimento dos fins pretendidos, de forma integrada e coordenada. Roberts e Wargo denominam este modelo planejamento abrangente (comprehensive planning).

É certo que, com os sucessivos cortes de verbas a cada ano para a rubrica destinada aos investimentos, será necessário um grande esforço conjunto, não somente dos gestores, com suas técnicas de otimização e maximização da utilização dos recursos, mas também dos engenheiros e fiscais de obras. Assim, estes últimos deverão se esforçar para utilizar de todas as técnicas de engenharia disponíveis e de toda sua criatividade, para efetuar a manutenção e correção de todo o sistema de esgoto da Marinha do Brasil, analisando quais são as obras realmente necessárias e quais são as que podem aguardar por um certo tempo, ou prever este período médio de utilidade, tornando a sua decisão a mais eficaz possível. Registrando-se que houve o corte de, aproximadamente, 6 bilhões nos recursos destinados às Forças Armadas. É realmente aprender a gerir por milagre todo o patrimônio e seu pessoal, todos os meios navais e todas as obras estratégicas que têm, por principal finalidade, garantir a segurança nacional.

Melhorar a gestão dos projetos e das execuções das obras é também uma meta da Diretoria de Obras Civis da Marinha. E esta planificação de atos a serem executados é de grande valia para a melhoria da eficiência e garantia da modernização do sistema de esgoto da Marinha do Brasil. 
Assim, diante das dificuldades analisadas no item anterior, pode-se vislumbrar alguns procedimentos a serem implementados, com o fim de melhorar o desempenho dos sistemas de esgotos.

A primeira sugestão é implementar uma rotina que garanta a atualização dos dados dos Planos Diretores das diversas Organizações Militares. Isso implica em efetuar um levantamento anualmente de todos os sistemas de esgoto das Organizações Militares, registrando a sua situação atual e a situação desejável, e se existe algum projeto de atualização do sistema existente.

Estes dados devem ser enviados para a Diretoria de Obras Civis da Marinha para que os quase 200 (duzentos) Planos Diretores ali arquivados, como levantado junto ao Departamento de Planejamento da MARINHA (2015), recebam uma permanente atualização. Esta atualização é imprescindível para que a Marinha do Brasil se mantenha em constante modernização do sistema, subsidiando o planejamento, especialmente a previsão de recursos para os projetos e obras necessários.

Decerto, os dados de atualização dependem do envio das informações técnicas especializadas, o que importa em identificação de outra fraqueza, pois nem sempre existe um profissional especializado no local que possa efetuar o levantamento de forma correta, o que irá representar um espelho da realidade de forma ofuscada.

A dificuldade no orçamento, por outro lado, influencia na contratação de profissionais para este fim e o que se deve buscar é minimizar esta situação reservando uma pequena verba para a contratação destes levantamentos, ainda que de forma simplista. Inserir no planejamento a alocação de recursos para a execução deste levantamento em cada Organização Militar que atenda, a médio prazo, as necessidades de dados atualizados é, pois, uma rotina que pode ser implementada, com o fim de cumprir as metas de modernização das instalações hidrosanitárias, mantendo um retrato da situação existente de acordo com a realidade.

A segunda sugestão se relaciona com os projetos e pode-se vislumbrar duas linhas de ação, que podem ser implementadas a médio e curto prazos, sendo de grande importância para a melhoria do desempenho do sistema de esgoto da Marinha do Brasil. 
A primeira linha de ação é relativa aos processos de licitação, que compreendem a inserção de uma visita técnica obrigatória, como condição de participação no certame, a fim de que os concorrentes tenham conhecimento das dificuldades que, porventura, possam encontrar como espaço físico disponível, necessidades da Organização Militar, facilidades e óbices existentes.

Além disso, na elaboração dos projetos básicos deve haver previsão da compatibilização dos projetos pela futura empresa contratada e a consequente submissão deste projeto, antes do início da execução das obras, para aprovação, bem como a execução de escavações na região que foi visitada previamente, conforme edital, para conferir se não há interferências não previstas antes do início das obras, mesmo após a visita técnica.

Esta postura requer da futura contratada que: observe as normas ambientais; elabore um projeto executivo com a maior quantidade de detalhamentos possível, que permita a máxima compatibilização com a realidade quando da realização da obra; entregue de forma contemporânea à assinatura do contrato o cronograma de execução das obras. E da contratante: a elaboração de um projeto básico o mais detalhado possível, para não ocorrerem dúvidas quanto aos processos, materiais, áreas, potências e demais detalhes técnico relevantes; preveja e aplique as penalidades; execute a fiscalização com o maior rigor possível; mantenha atualizado todos os lançamentos de alterações de projeto ou irregularidades em arquivo próprio e disponível a qualquer momento para análises.

A segunda linha de ação para os projetos relaciona-se com a própria execução da obra, após a seleção da empresa e consequente contratação. Uma fiscalização é obrigatória para todos os contratos, conforme descrito no item 67, da Lei nº 8.666 (BRASIL, 1993). Entretanto, esta fiscalização deve observar que antes da confecção do sistema de esgoto é necessário um planejamento adequado de todas as etapas construtivas. E estas etapas devem ser apresentadas previamente à fiscalização, para que sirvam de orientação sobre o que vai ser efetuado e, consequentemente, se há algum erro neste planejamento como escavação em redes pré-existentes em funcionamento e alteração do projeto licitado, sem autorização prévia.

Assim sendo, um cronograma contendo as etapas da obra deve ser apresentado antes do início da execução da obra e esta situação é de 
responsabilidade fiscal, que não pode deixar de fazer cumprir esta obrigação da contratada. Além disso, o fiscal deve aplicar as penalidades cabíveis, sem deixar de observar a devida proporção em relação à violação da norma praticada pela contratada; proceder todas as anotações e alterações ocorridas no livro de registro que deve ser mantido no canteiro de obras; receber todos os projetos "as built"; acompanhar todas as marcações do encaminhamento das tubulações, a fim de eliminar a ocorrência de sobreposição ou escavação irregular no futuro; levantar dados com os militares do quartel, a fim de obter o máximo de informações possíveis sobre a tubulações/instalações existentes que, porventura, não tenham sido informadas quando da elaboração dos projetos. O levantamento de dados deve especular em entrevistas, levantamento de arquivos locais, histórico por fotos e a própria inspeção do local.

Todas estas rotinas e procedimentos certamente irão gerar uma gestão mais eficiente, que irá por consequência melhorar o desempenho de todo o sistema de esgoto, tanto na eficácia de projetos mais bem elaborados, quanto obras executadas com diminuição de erros de execução e aumento de registros que poderão ser acessados no futuro, melhorando a gestão dos dados do sistema de esgoto da Marinha do Brasil. 


\section{3 \\ LICENCIAMENTO AMBIENTAL DO SISTEMA DE ESGOTO NOS EMPREENDIMENTOS MILITARES}

A visão atual da ação efetiva ou potencialmente poluidora, ou aquelas que, sob qualquer forma, possam causar degradação ambiental, conjugada com a localidade do impacto é uma situação complexa e que se faz relevante para a apreciação do efetivo desempenho do sistema de esgoto. Isto porque a existência de um sistema de esgoto ineficiente passa a ser um elemento poluidor em potencial do meio ambiente, o que pode ser analisado e tratado de forma preventiva.

No contexto da sustentabilidade ambiental, o descarte dos efluentes é uma das principais preocupações que tem sido estudada, com grande potencial de poluição dos corpos receptores. No Brasil, em regra, ainda há descartes feitos de forma desregrada e sem qualquer tipo de tratamento. Esta situação reiterada, decorrente tanto da limitação das redes existentes quanto dos costumes e da ausência de educação e consciência ambiental, está tendo como resposta a má qualidade das água captadas dos recursos hídricos para consumo e a propagação de doenças quando do seu uso em lazer, já que os descartes são, em sua esmagadora maioria, lançados em corpos receptores, dentre rios e mar.

Com a evolução do problema, como em toda sociedade, a resposta surge por meio de edições de normas, que objetivam reduzir o problema, mas não garantem a sua eficácia e aplicabilidade. Além disso, os critérios para a análise da obrigatoriedade ou não do licenciamento ambiental continuam subjetivos, o que causa interpretações distintas pelos agentes lotados nos diversos órgãos ambientais, pois são muitas as variáveis para a análise da situação na prática.

Verificar a aplicabilidade das normas ambientais, especificamente nos empreendimentos militares, analisando qual é o órgão competente para o processo e análise, quando devem ser utilizadas as normas, como atuar diante de empreendimentos de preparo e emprego da força, e como se enquadra a situação do licenciamento do sistema esgoto é, então, mais uma análise importante para que se possa melhorar o seu desempenho. 


\section{1}

\section{A Importância da Preservação do Meio Ambiente para a Marinha do Brasil}

Da mesma forma que a Marinha do Brasil, uma instituição fundada na hierarquia e disciplina, trata com seriedade os assuntos atinentes a sua missão constitucional, estabelecida no art. 140 da Constituição (BRASIL, 1988), esta também tem estabelecido programas e aplicado na prática a gestão ambiental em suas diversas unidades organizacionais. Isto tem sido executado por meio de ações administrativas variadas, as quais são orientadas pelas normas ambientais, que contém uma imensa gama de condutas e previsões técnicas que indicam o caminho a ser trilhado para um mundo sustentável com recursos finitos.

Desta forma, sempre pronta para prover a defesa e a garantia da segurança e instituições nacionais, as Forças Armadas, de forma reiterada, atuam em segundo plano para implementar a defesa do meio ambiente, cuja ação de plano de fundo é imprescindível para o êxito dos programas e políticas governamentais.

Um bom exemplo deste modelo de atuação pode ser constatado na Conferência das Nações Unidas sobre o Meio Ambiente e Desenvolvimento (CNUMAD), ocorrida no Rio de Janeiro em 1992, conhecida como ECO 92 (SENADO, 2015). É de se observar que a garantia para o bom cumprimento das reuniões e debates foi apoiada pelas Forças Armadas, o que garantiu a confiança dos participantes e o bem estar de todos durante a ocorrência dos inúmeros eventos, espalhados territorialmente, e com grande número de representantes do mundo inteiro, incluindo Chefes de Estado.

Ademais, a ideia de sustentabilidade e de desenvolvimento sustentável, embriões gerados por ocasião da ECO 92 (SENADO, 2015), em suas várias roupagens teóricas e ideológicas, emergiram como conscientização ambiental no âmbito das Forças Armadas em seus diversos setores: seja administrativo, com a implementação de medidas sustentáveis; seja na área da construção civil, com a adoção de editais sustentáveis e demais medidas protetivas; seja com o uso de técnicas sustentáveis nas áreas de energia, água, descarte de materiais, reciclagem e demais medidas conhecidas e aplicáveis nos quartéis destinados aos seus diversos fins, operativos ou não. Segundo FREITAS (2011, p.39): 
A sustentabilidade não é, pois, princípio abstrato ou de observância adiável: vincula plenamente e se mostra inconciliável com o vicioso descumprimento da função socioambiental dos bens e serviços... traduz-se sustentabilidade como dever fundamental de, inclusive a longo prazo, vivenciar e partilhar o desenvolvimento limpo e propício à saúde, em todos os sentidos, aí abrangidos os componentes éticos, em combinação com os elementos sociais, ambientais, econômicos e jurídico-políticos.

Diversas ações sustentáveis já foram implementadas pela Marinha do Brasil, como as recuperações de Estações de Tratamento de Esgoto (ETE) em diversas unidades militares, tal como no Colégio Naval, na Escola Naval e outras unidades com grande população contribuinte. Também ocorreram a implementação de planos de manutenção de fossas, como forma de melhorar o desempenho de sua função e a liberação de efluentes nos corpos receptores com maior qualidade.

Outras ações ainda estão em fase de elaboração para a modernização dos sistemas, como é o caso dos estudos de aproveitamento do lixo orgânico e a sua destinação no Centro de Instrução Almirante Wandenkolk (CIAW), ilha localizada na Baía de Guanabara, cuja principal missão é a formação de nossos militares oficiais.

Nesta Organização Militar, de localidade complexa conforme indicado na figura 3.1, a logística para a destinação dos resíduos ali gerados é complexa e tem recebido a devida atenção da Administração Naval.

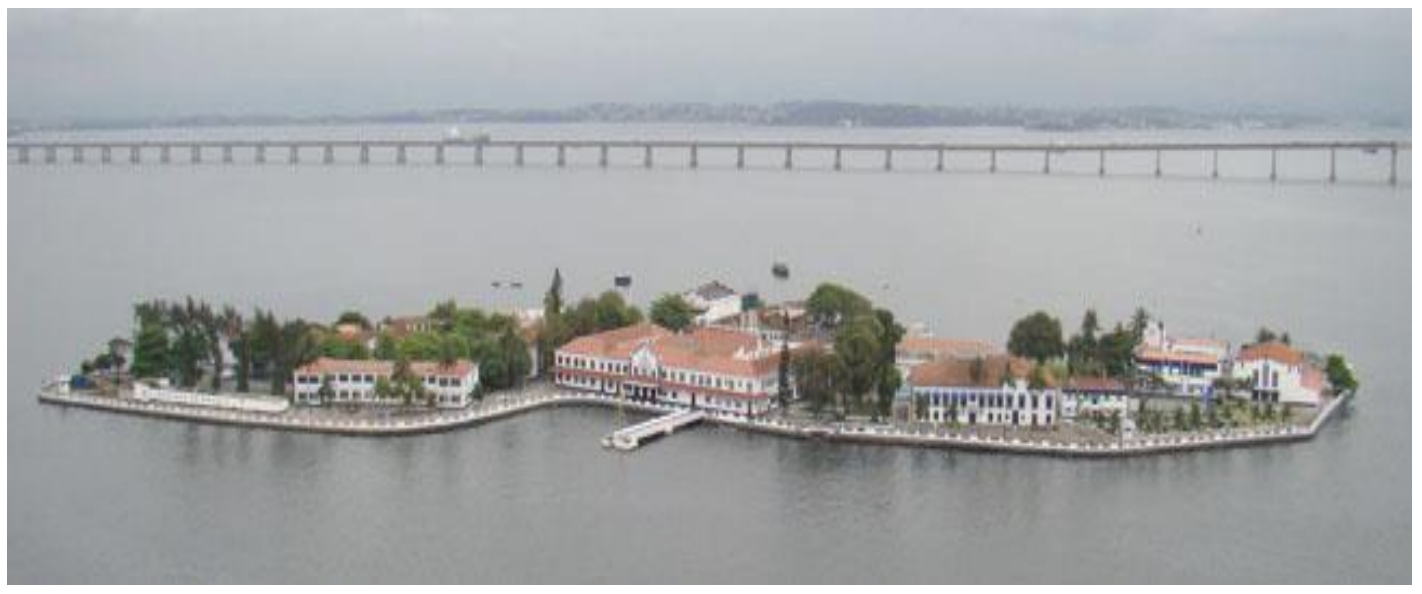

Figura 3.1: Programa de Despoluição da Baía da Guanabara. Ilha do CIAW. Fonte: http://www.mar.mil.br.

Dentre as ações já implementadas nesta Organização Militar incluem-se a revitalização de uma Estação de Tratamento de Esgoto (ETE), indicada na figura 3.2, que se encontra em pleno funcionamento, com o fim de efetuar o adequado 
tratamento do esgoto sanitário para a garantia da qualidade dos efluentes ali produzidos, medida esta que vai ao encontro do Programa de Despoluição da Baía de Guanabara.

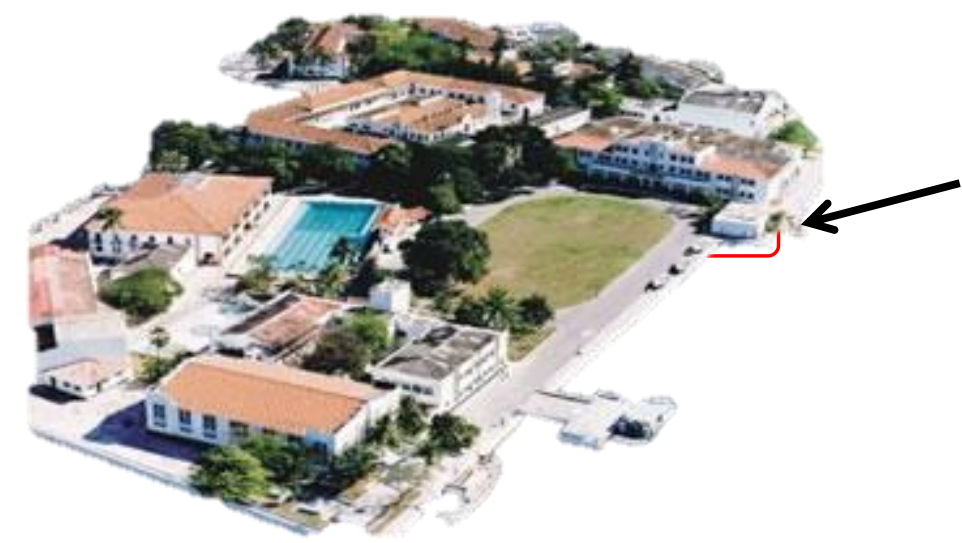

Figura 3.2: Estação de Tratamento de Esgoto. Ilha do CIAW Fonte: a autora.

Ainda em consonância com o Programa de Despoluição da Baía de Guanabara, a Marinha do Brasil está executando projetos básicos e licitações com o fim de executar obras de saneamento, como no Complexo da Avenida Brasil, figura 3.3, de forma a efetuar as interligações das redes de esgoto dentro dos Complexos Navais e transportar os seus efluentes para a rede pública, ação esta que vai eliminar o descarte direto que ainda ocorre em algumas situações, como melhor será apresentado no Capítulo 5.
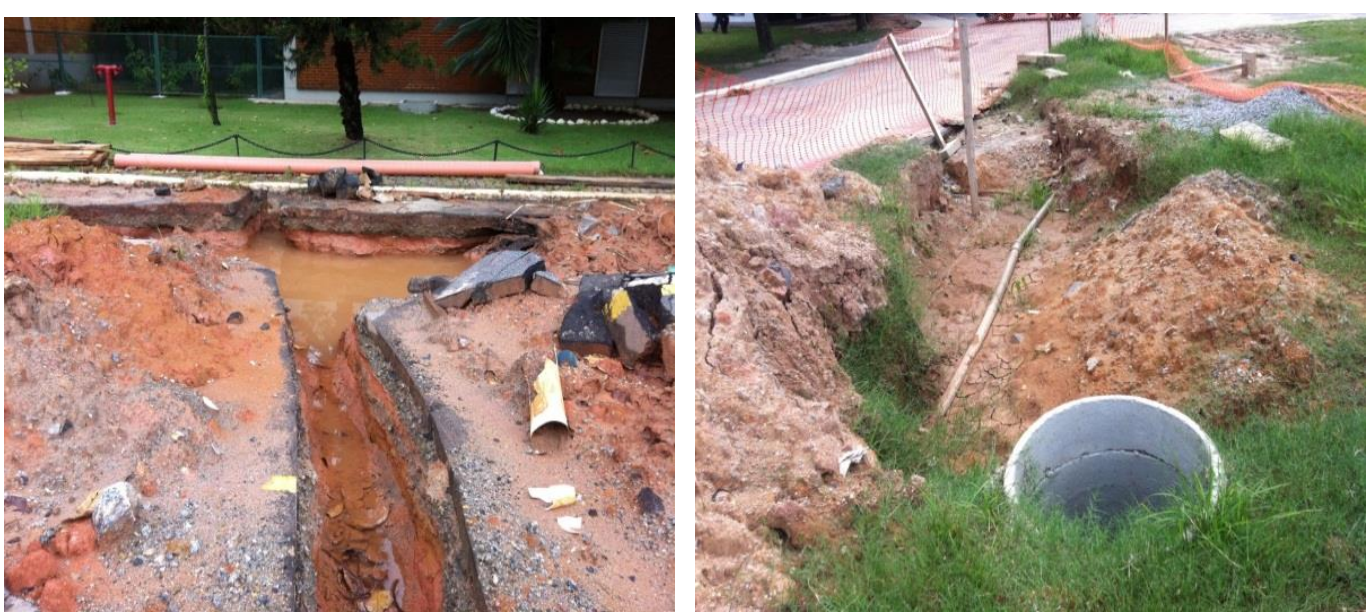

Figura 3.3: Obras de saneamento do Complexo da Avenida Brasil. Fonte: a autora. 
Outro grande desafio para a Marinha do Brasil é prover o descarte dos efluentes diretamente nas redes públicas, com o fim de aproveitar o sistema de tratamento do Estado. No sistema de esgoto naval por todo o Brasil verifica-se que os sistemas de tratamento dos efluentes e as redes coletoras públicas ainda necessitam de expansão para que atendam toda a sua necessidade real. Como exemplo, constata-se que em muitos trechos no entorno da Baía de Guanabara, no Rio de Janeiro, a rede coletora ainda se encontra em expansão, sem disponibilizar troncos coletores que atendam os empreendimentos militares para a coleta dos seus efluentes, que, em projeto, deveriam ser encaminhados para a Estação de Tratamento de Esgoto Alegria.

Nas localidades mais afastadas, distribuídas por todo o território nacional e fora das grandes cidades, é comum não existir a rede coletora para a coleta dos efluentes de todas as unidades residenciais.

Segundo dados obtidos no Sistema Nacional de Informações sobre Saneamento - SNIS (Ministério das Cidades, 2016), ainda há necessidade de implantação de tratamentos de esgoto pelo país. Assim, tem-se índices de atendimento urbanos variáveis.

Dados do SNIS de 2014 indicam que:

- na região norte verifica-se índice médio menor que 10\%;

- na região nordeste $50 \%$ em média;

- na região centro oeste entre 40 e $70 \%$;

- na região sul entre 20 a 40\%; e

- na região sudeste em torno de $70 \%$. Nas localidades aonde ainda há dificuldades de coleta, a Marinha do Brasil adota, nas construções já existentes, tratamentos dos efluentes com as fossas sépticas, complementadas por filtros, método este implantado há muitos anos e que é garantido por manutenções periódicas, como indicado na figura 3.4, o que gera uma destinação adequada dos seus efluentes para os corpos receptores, eliminando-se em razoável grau (em torno de 60\%) a contaminação nociva dos corpos d’água. Para as novas construções, quando adequado para o projeto, são instaladas Estações de Tratamento de Esgotos (ETE), como no caso do Centro de Munição da Marinha, localizado na Ilha do Boqueirão, na Ilha do Governador, ou qualquer outro dispositivo que represente maior eficiência e adequação ao caso concreto. 


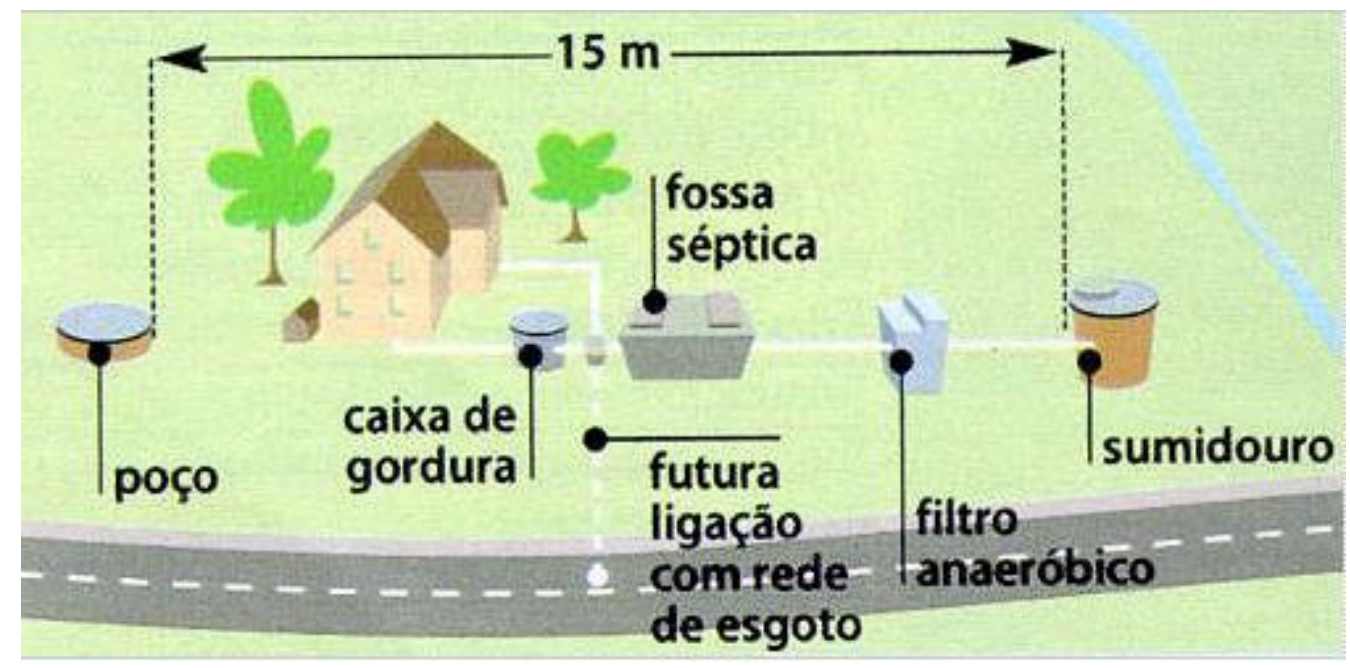

Figura 3.4: Exemplo de esquema fossa-filtro. Fonte: http://www.webcentral.com.br/massao/pg005.html.

Sob a vertente científica, a Marinha do Brasil possui programas voltados para o acompanhamento e controle da poluição do mar e dos rios. A Comissão Interministerial para os Recursos no Mar (CIRM) é a Organização Militar coordenadora dos programas ligados ao uso racional das águas jurisdicionais. Os principais programas são:

- Programa de Avaliação da Potencialidade Mineral da Plataforma Continental Jurídica Brasileira (REVIMAR);

- Ação da Biotecnologia Marinha (BIOMAR);

- Ação Promoção de Mentalidade Marítima (PROMAR);

- Programa Arquipélago de São Pedro e São Paulo (PROARQUIPÉLAGO);

- Programa de Pesquisas Científicas na Ilha de Trindade (PROTRINDADE)

- Sistema Brasileiro de Observação dos Oceanos e Clima (GOOS/Brasil)

Existem diversas outras ações já consagradas pela instituição naval, como as auditorias ambientais, os seminários e as reuniões acerca da coordenação entre a proteção ambiental e a missão das Forças Armadas, além de gestão administrativa que contém processos que preveem ações integradas de educação ambiental. 
Como exemplo, destaca-se a comemoração do Dia Mundial do Meio Ambiente, celebrada no por meio de um Seminário realizado no Arsenal de Marinha do Rio de Janeiro, no mês de junho. Sempre em treinamento e buscando a melhoria da eficiência, é certo que diversos eventos já são consagrados como a Regata Ecológica anual na Escola Naval, figura 3.5, que ocorreu no dia 20 de maio de 2015 , em sua $16^{\text {a }}$ edição, tendo captado $250 \mathrm{Kg}$ de lixo na Baía de Guanabara (MARINHA, 2015), incentivando e conscientizando os jovens participantes às práticas sustentáveis e ao espírito de amor ao mar, a segunda casa do marujo.

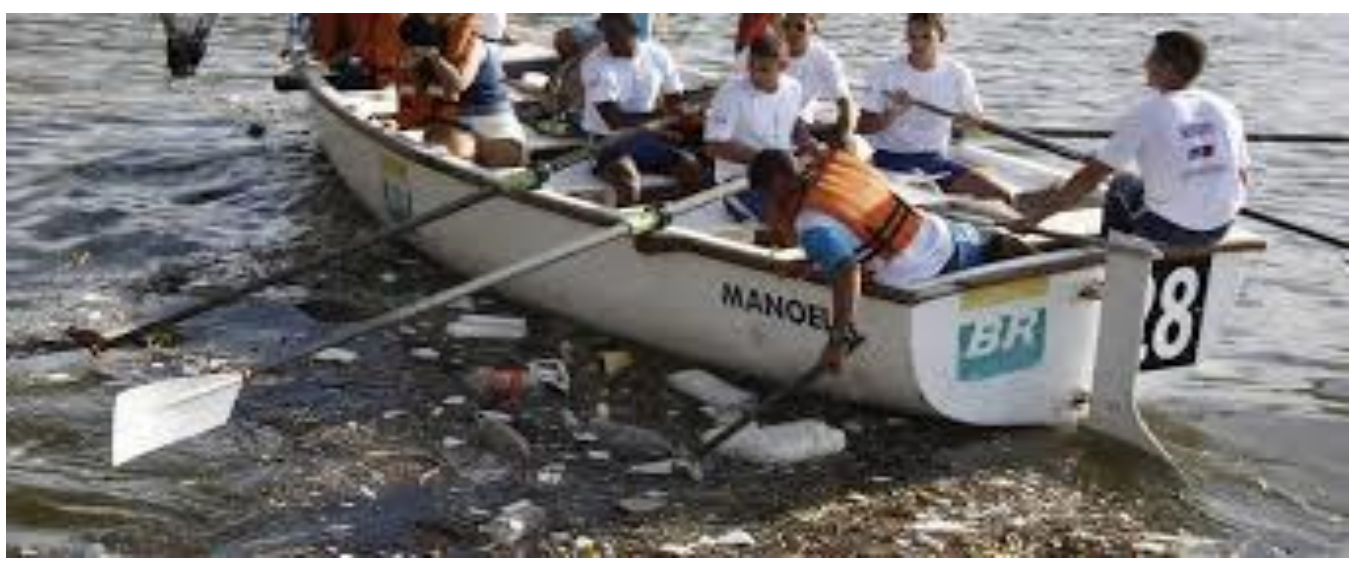

Figura 3.5: XVI Regata Ecológica na Escola Naval. Fonte: http://www.mar.mil.br.

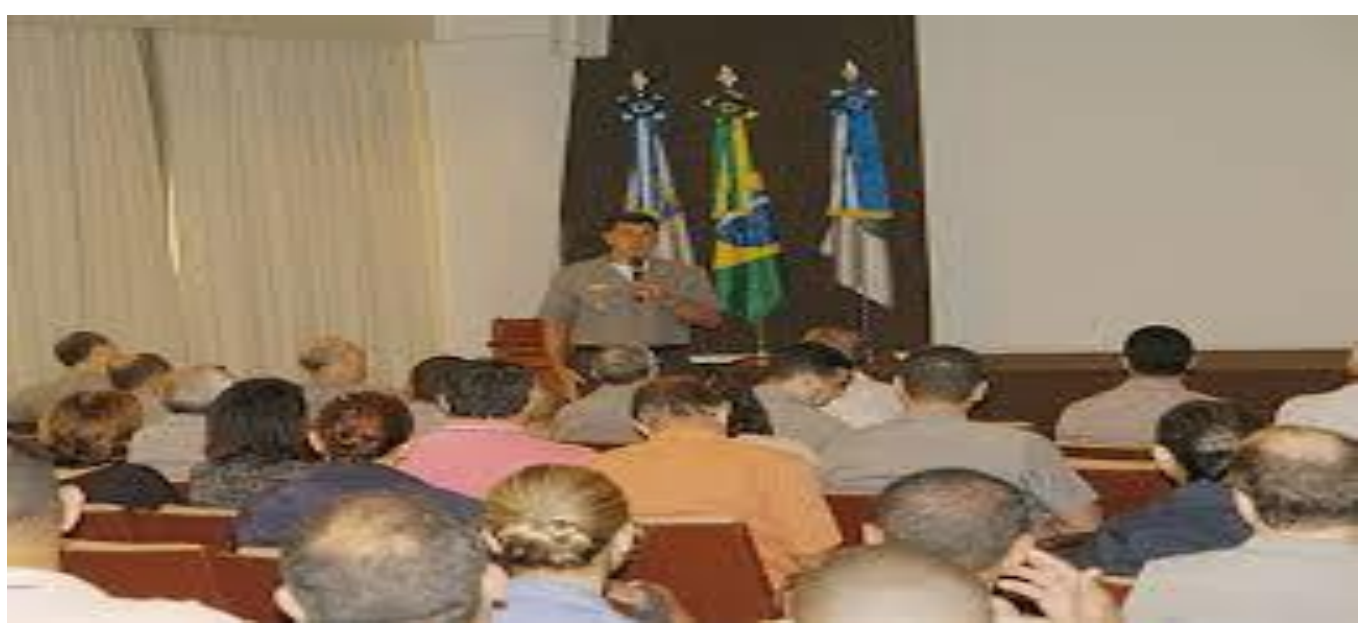

Figura 3.6: Seminário de Meio Ambiente no Arsenal de Marinha no Rio de Janeiro (AMRJ). Fonte: http://www.mar.mil.br.

Muitas são as ações sociais das Forças Armadas no sentido de proteger o meio ambiente, como o seminário de meio ambiente da figura 3.6, resgates de animais por brigadas ambientais, seja em terra, seja em mar, e com iniciativas de 
educação ambiental, como as utilizadas nas populações ribeirinhas ao longo de todo o Brasil, o que inclui diversas orientações, tais como a importância da instalação e uso dos vasos sanitários, como efetuar o descarte do esgoto sanitário, a execução de obras de saneamento em geral, o consumo consciente dos recursos naturais e o uso adequado de equipamentos e materiais que são doados para estas populações, como a operação Amazônia Azul, figura 3.7.

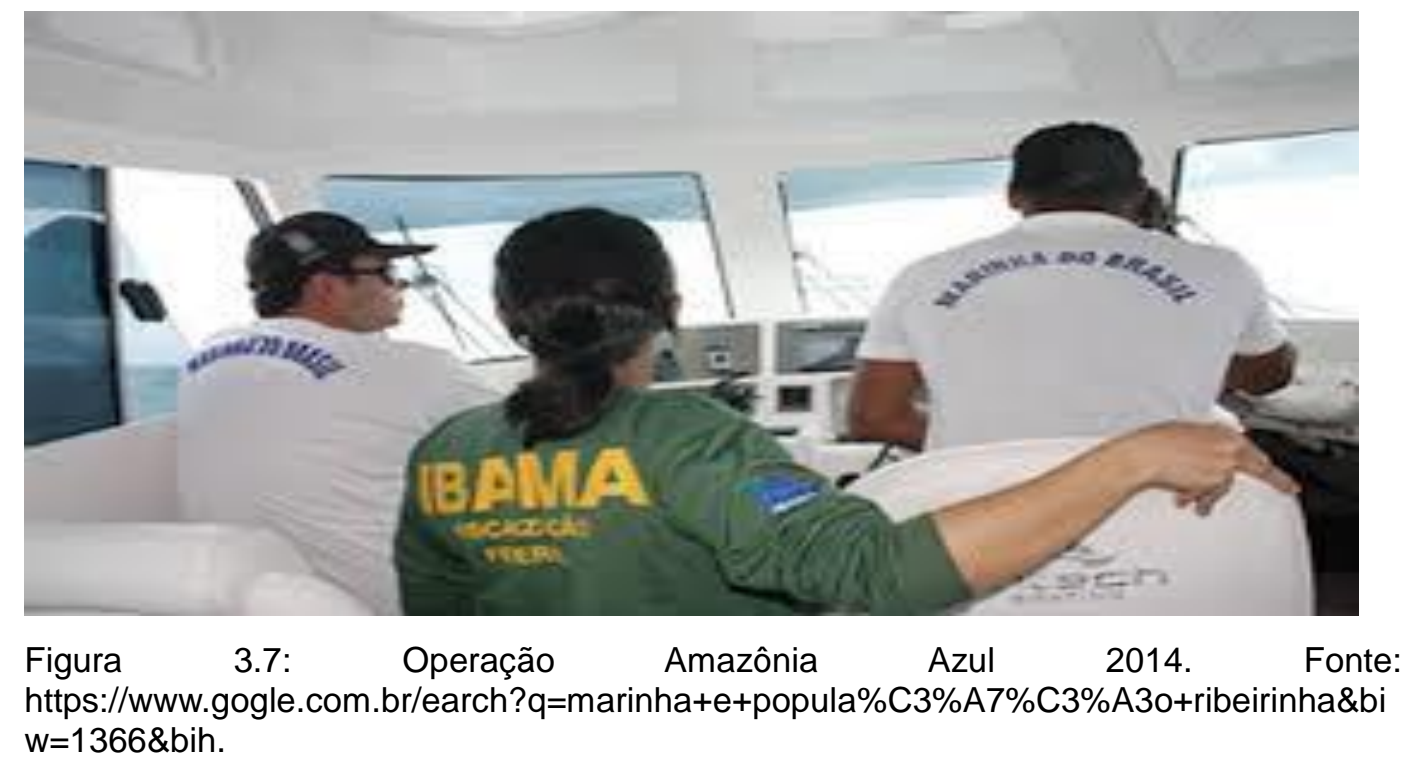

A despeito da importância consciente da proteção ambiental descrita acima, para atender a missão destinada à Marinha, é necessária a existência de organizações terrestres e construções marítimas, seja em localidades consideradas estratégicas, seja em localidades comuns, mas com o uso estratégico. E essa interferência sobre a natureza pode ser analisada em casos específicos como quando ocorre a afetação para o preparo e emprego do pessoal e dos meios de defesa, dada a importância estratégica da proteção nacional.

Por tudo acima, é certo que a Marinha do Brasil tem como uma de suas tarefas a proteção do meio ambiente. E este assunto é de tamanha relevância que, em uma visão estratégica (MARINHA, 2015), inclui em sua missão, além do preparo e emprego do Poder Naval, o cumprimento das atribuições subsidiárias previstas em Lei, com ênfase naquelas relacionadas à Autoridade Marítima, a fim de contribuir para a salvaguarda dos interesses nacionais.

Além disso, como visão de futuro (MARINHA, 2015), é previsto que: 
a Marinha do Brasil será uma Força moderna, equilibrada e balanceada, e deverá dispor de meios navais, aeronavais e de fuzileiros navais compatíveis com a inserção político-estratégica do nosso País no cenário internacional e, em sintonia com os anseios da sociedade brasileira, estará permanentemente pronta para atuar no mar e em águas interiores, de forma singular ou conjunta, de modo a atender aos propósitos estatuídos na sua missão .

Percebe-se, pois, que a atuação junto às águas do mar e águas interiores requer a sua proteção, em todos os sentidos, ou seja, também deve proteger estas águas da poluição, razão pela qual, a sua atuação deve garantir a observância das normas ambientais, bem como ponderá-las diante do conjunto de tarefas constitucionais, minimizando, sempre que possível, os impactos desta atuação.

Especialmente no que concerne às situações de contraposição, entre os anseios de garantia do êxito da missão e a sua atuação como protetor das águas interiores e jurisdicionais, é que se encontra uma solução de continuidade, cuja problemática deve ser analisada com extremo rigor.

O rigor é necessário porque a regra é a proteção ambiental e os casos de dispensa legais devem ser precisos, claros para que o órgão ambiental possa analisa-los da forma o mais objetiva possível. E a regra do licenciamento é para ser vista dentro dos limites legais. Nos casos excepcionais de preparo e emprego da força existe legislação específica que permite a dispensa do licenciamento ambiental a ser emitida pelo órgão ambiental, como será visto adiante.

\section{2}

\section{O Sistema de Esgoto, as Normas Ambientais e as Auditorias}

O Estado diante da questão ambiental manifesta uma situação paradoxal: parte de seu aparelho constitui os principais canais institucionais de defesa da qualidade do meio ambiente, outra parte constitui os principais agentes de degradação. A resolução do paradoxo nos remete ao grau de controle do Estado pela sociedade MORAES (2005, p. 57).

O meio ambiente passou a ser entendido como necessário e indispensável para o ser humano, no momento em que este se conscientizou de que os recursos naturais não são infinitos. Então, como usualmente ocorre na história da elaboração das normas jurídicas, a matéria passou a receber o status de direito a ser protegido pelo Estado, legitimador das ações de força e ordem, pois que, intrinsecamente à garantia pelo Poder Público, se encontram na norma três 
características: imperativa, geral e abstrata, como informa GUSMÃO (1991, p. $105)$.

Embora já admitido em nossa Constituição, preleciona MORAES (2005, p. 24-25) que o direito ambiental deveria ser concebido como um vetor que necessita internalizar-se nos diversos programas e ações estatais, dando-lhes também um instrumento de articulação, ou seja, de verdadeira efetivação e não apenas uma expressão ideológica sem a correspondente materialização no mundo físico. MORAES (2005, p. 26) acrescenta, ainda que:

Um adequado planejamento ambiental mexe com muitos interesses, sendo estruturalmente um potencializador de conflitos... Em nossa realidade difícil, nem sempre o ambientalmente correto segue junto com os anseios sociais, e encontrar o ponto de equilíbrio entre a norma técnica e a justiça social nem sempre é tarefa fácil.

De fato, conjugar os diversos interesses que surgem das necessidades humanas é ação que exige muita cautela do Estado, tanto no âmbito do legislativo, quanto do judiciário e do executivo. Todos apresentam demandas próprias, inerentes as suas multifacetadas tarefas. Além disso, prover a proteção ambiental por meio dos órgãos públicos é uma difícil missão, quando o paradigma de crescimento econômico ainda se funda na exploração dos recursos naturais, portanto em um desenvolvimento insustentável diante do crescente aumento exponencial do consumo.

O sistema de esgoto, dentro desse contexto de sustentabilidade, é um dos grandes contribuintes da poluição ambiental, especialmente dos corpos hídricos, para onde usualmente é despejado. E essa cultura de despejo direto aos corpos hídricos, cujo crescimento demográfico histórico se deu ao longo dos rios e mares, criou o grande problema da atualidade das grandes cidades. Rio mortos, mares contaminados, fontes de água contaminadas.

O Estado recebeu o dever de cuidar da distribuição da água e da coleta dos esgotos, como está estabelecido na própria Constituição da República Federativa do Brasil, como já indicado nos capítulos anteriores. No entanto, e apesar dos esforços positivos em favor do crescimento de atendimento aos consumidores, ainda não conseguiu atuar de forma a garantir a coleta de todo o esgoto do país. Segundo dados contidos no Diagnóstico de Serviços de água e esgoto, ano 2014, 
do SNIS (Ministério das Cidades, 2016), verifica-se o índice médio de atendimento urbano por redes coletoras de esgoto no país conforme abaixo:

\begin{abstract}
Em relação aos estados, o índice médio de atendimento urbano com rede coletora de esgotos aponta valores acima de $70 \%$ apenas no Distrito Federal e em 3 estados, São Paulo, Minas Gerais e Paraná, mesmas Unidades da Federação de 2012 e 2013, com a inclusão apenas dessa última. Na faixa de $40 \%$ a $70 \%$, aparecem outros 6 estados, Rio de Janeiro, Espírito Santo, Goiás, Mato Grosso do Sul, Bahia e Paraíba (esse último subiu de faixa com relação a 2013); na faixa logo abaixo, de $20 \%$ a 40\%, situam-se 9 estados, Roraima, Rio Grande do Sul, Ceará, Alagoas, Rio Grande do Norte, Mato Grosso Pernambuco, Sergipe e Tocantins (esse último subiu de faixa com relação a 2013); enquanto que na penúltima faixa, $10 \%$ a $20 \%$, encontram-se 4 estados, Santa Catarina, Acre, Maranhão e Piauí (esse último subiu de faixa com relação a 2013). Por fim, na menor faixa, inferior a 10\%, há 4 estados, Amazonas, Pará, Rondônia e Amapá, um a menos que em 2013.
\end{abstract}

Portanto, ainda temos a necessidade de um processo de aumento de atendimento urbano para que todos sejam atendidos no país. E ter atendimento urbano não impede que outras mazelas de poluição ocorram, em decorrência da contaminação crescente dos corpos receptores por falta de educação ambiental da própria sociedade.

A população permanece lançando esgoto sanitário diretamente para os corpos hídricos, necessitando de educação ambiental e outros projetos estratégicos, tais como o incentivo à despoluição de seu local de moradia, o remanejamento das residências em áreas de risco, dentre outros programas que afetam e dependem diretamente de orçamento público ou apoio da sociedade.

Segundo a Resolução no 237 (CONAMA, 1997), os empreendimentos e as atividades elencadas no Anexo I estão sujeitos ao licenciamento ambiental. E neste anexo ficou claro que toda atividade que gere resíduo contaminante deve sofrer licenciamento. E os efluentes de esgoto não tratados e sem controle são resíduos contaminantes em potencial, localizando-se neste rol do Anexo I. Para aonde deveriam ir os resíduos líquidos, senão para um sistema de esgotamento eficiente? Certamente, os tratamentos podem segregar os elementos contaminantes, tratá-los quimicamente, mas em quase sua totalidade o sistema de tratamento irá gerar resíduo líquido, que será despejado de volta ao meio ambiente, que pode já estar acima de seu limite de captação de carga orgânica. É este cuidado com a qualidade destes efluentes, seja quimicamente alterados, seja 
com carga orgânica contaminante, que deve ser considerado quando do licenciamento.

Algumas atividades previstas no Anexo I, da Resolução $\mathrm{n}^{\circ} 237$ (CONAMA, 1997) tem relação com o sistema de esgoto, ou seja, que pode ser desenvolvida nas Organizações Militares da Marinha do Brasil, são identificadas no referido anexo e descritos abaixo na tabela 3.1:

Tabela 3.1: Atividades ou empreendimento que se submetem ao Licenciamento Ambiental. Fonte: CONAMA.

\begin{tabular}{|c|c|}
\hline ATIVI & NIZAÇÃO MILITAR \\
\hline $\begin{array}{l}\text { fabricação e reparo de embarcações e } \\
\text { estruturas flutuantes }\end{array}$ & $\begin{array}{l}\text { Arsenal de Marinha do Rio de } \\
\text { Janeiro, Centro de Embarcações } \\
\text { Miúdas }\end{array}$ \\
\hline fabricação de produtos farmacêuticos & Laboratório Farmacêutico da Marinha \\
\hline fabricação de estruturas metálicas & Unidade de Fabricação Metálica \\
\hline $\begin{array}{l}\text { fabricação de máquinas, aparelhos, peças, } \\
\text { utensílios e acessórios }\end{array}$ & $\begin{array}{l}\text { Arsenal de Marinha do Rio de } \\
\text { Janeiro }\end{array}$ \\
\hline $\begin{array}{l}\text { fabricação de artefatos de papel, papelão, } \\
\text { cartolina, cartão } \\
\text { fabricação de pólvora/explosivos/detonantes/ }\end{array}$ & $\begin{array}{l}\text { Departamento Industrial Gráfico } \\
\text { Centro de Instrução Almirante } \\
\text { Milcíades Portela }\end{array}$ \\
\hline estações de tratamento de água & Diversas unidades militares \\
\hline $\begin{array}{l}\text { interceptores, emissários, estação elevatória e } \\
\text { tratamento de esgoto sanitário }\end{array}$ & ares \\
\hline $\begin{array}{l}\text { tratamento e destinação de resíduos industriais } \\
\text { (líquidos e sólidos) }\end{array}$ & Diversas unidades militares \\
\hline $\begin{array}{l}\text { tratamento e destinação de resíduos sólidos } \\
\text { urbanos, inclusive aqueles provenientes de } \\
\text { fossas }\end{array}$ & $80 \%$ \\
\hline dragagem e derrocamentos em corpos d'água & Diversas u \\
\hline $\begin{array}{l}\text { recuperação de áreas contaminadas ou } \\
\text { dearadadas }\end{array}$ & Est \\
\hline
\end{tabular}

\subsection{1}

\section{As Normas Ambientais}

A defesa do meio ambiente nasce dentro de uma complexidade de normas paralelas, algumas, inclusive, pré-existentes à atual Carta Constitucional, e culmina com a sua inserção no topo da pirâmide kelsiana das normas brasileiras, 
constando no art. 225, da Constituição (BRASIL, 1988), a sua imprescindibilidade, criando para todos os entes federativos a competência comum, o que causou imensa confusão interpretativa no campo da efetivação do caso concreto, culminando em interferências administrativas entre os órgãos ambientais, com a expedição de normas idênticas e sobreposição de fiscalizações.

Segundo Paulo Dourado Gusmão, em seu livro Introdução ao Estudo do Direito, 14 ed. São Paulo: FORENSE, p.123, 1991, a ideia de norma fundamental deve-se a Kelsen e pode ser considerada como a norma de validade de todas as normas jurídicas, pois é dotada de validez pressuposta, pois, se não fosse válida, as demais normas que dela provêm seriam destituídas de validade. Ainda, situando-se na repartição da competência, segundo o art. 23 da CRFB/88, a competência comum é para ser exercida em situação de cooperação. Mas, de fato, no âmbito do direito ambiental, esta cooperação não consegue definir claramente quem é o órgão competente para analisar as situações a serem submetidas aos órgãos ambientais para obtenção dos licenciamentos.

Segundo MORAES (2005, p.30), o âmbito da gestão ambiental se classifica na política territorial. E isso refletiria de forma complexa, pois a dispersão geográfica complicaria a institucionalização da gestão ambiental, já que se encontra sediada, basicamente, no poder executivo dos entes da federação. Desta forma, os órgãos de gestão ambiental conhecem uma estruturação cêntrica, numa hierarquia que tem como ápice a União, que combina uma proposição de um sistema cooperativo associado com os demais níveis de governo.

Mas este sistema cooperativo não se materializou de forma harmônica. As diversas normas emanadas dos entes federativos passaram a enfrentar a situação fática de sobreposição de objetos protegidos, pois que as classificações variavam entre o interesse espacial, com a divisão entre local, regional e nacional; e o impacto gerado, com a divisão em grande, médio e baixo. Nestas divisões existem pontos de interseção que causam conflito de competências, o que recaía no centrismo federativo, a quem cabia, e ainda cabe, decidir ou delegar, segundo as regras da Resolução nº 237 (CONAMA, 1997).

As normas ambientais podem ser assim resumidas: As normas ditadas pela Constituição da República Federativa do Brasil (BRASIL, 1988), conforme artigos 182, 186 e 225. Logo abaixo, as duas principais normas federais. A que cria a Política Nacional de Meio Ambiente - PNMA, Lei $n^{\circ} 6.938$ (BRASIL, 
1981) e a que delimita os crimes ambientais, Lei $n^{\circ} 9.605$ (BRASIL, 1998). Logo abaixo se tem Decretos, Leis, além das inúmeras Resoluções e Normas Técnicas, como as ISOS, e tudo pode ser expedido pelos três entes federativos.

A competência ambiental somente tem um estado aparente de organização. Entretanto, na prática, há verdadeira interferência entre as competências, o que pressupõe a necessidade da emissão de normas que delimitem as diversas práticas ambientais, já que, no âmbito da competência comum, há grande problemática em sua delimitação. A competência ambiental pode ser verificada conforme indicado na figura 3.8 .

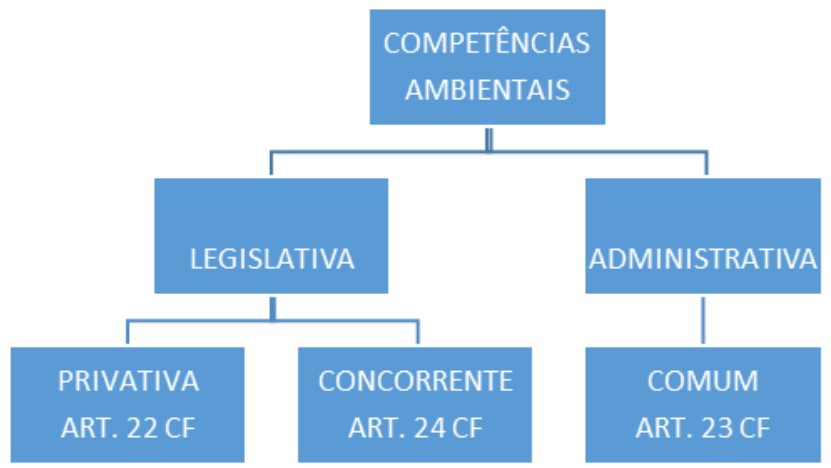

Figura 3.8: Competências ambientais constitucionais. Fonte: a autora.

Na Marinha do Brasil, órgão da União, é fato que se deve observar todas as normas ambientais, em especial submeter-se ao órgão ambiental com competência para o licenciamento do sistema de esgoto, que é o Instituto Brasileiro do Meio Ambiente e dos Recursos Naturais (IBAMA), que pode delegar esta competência, mas não perde a sua competência originária. E esta é a grande regra.

Todavia, nos casos especiais de preparo e emprego do poder naval, casos estes previstos na legislação federal, pode ser considerada a dispensa da licença, a ser concedida pela fiscalização externa - órgão ambiental, a fim de permitir a materialização da missão constitucional das forças armadas. E para este processo de dispensa devem existir cuidados tão ou mais rígidos que os contidos nos licenciamentos ambientais comuns e, dentro deles, sugere-se a execução de auditorias ambientais, relatórios fotográficos detalhados da evolução histórica, dentre outros, que se passa a descrever. 


\section{2 .2}

\section{AUDITORIAS AMBIENTAIS: um instrumento de medição do desempenho}

Na Administração Militar a importância da temática ambiental recebe o seu devido destaque, especialmente no que tange ao Sistema de Gestão Ambiental (SGA), que é a parte do sistema de gestão global que inclui estrutura organizacional, atividades de planejamento, responsabilidades, práticas, procedimentos, processos e recursos para desenvolver, implementar, atingir, analisar criticamente e manter a política ambiental. Assim, as auditorias ambientais são executadas de forma periódica, em atenção ao SGA de cada Força Armada, que, segundo o item 3.6, da NBR ISO 14.001 (BRASIL, 2004), é:

Um processo sistemático e documentado de verificação, executado para obter e avaliar, de forma objetiva, evidências que determinem se o sistema de gestão ambiental de uma organização está em conformidade com os critérios de auditoria do sistema de gestão ambiental estabelecido pela organização, e para comunicar os resultados deste processo à administração.

Das ações atinentes às auditorias ambientais surgem relatórios com procedimentos a serem seguidos, correções a serem observadas, posturas a serem implementadas.

No âmbito da Administração Naval, esta competência cabe à Diretoria de Portos e Costas (DPC), organização militar que tem como principal tarefa exercer a fiscalização como autoridade marítima brasileira. Uma das áreas de atuação da DPC é fiscalizar e proteger o meio ambiente, especialmente no que tange ao trânsito e uso das embarcações. Mas além das embarcações, esta Diretoria atua em auditorias ambientais nas organizações militares, a fim de verificar a adequação das instalações que possuem risco ou potencial de risco danoso ao meio ambiente e das ações atinentes à implementação de um Sistema de Gestão Ambiental (SGA).

As principais Normas Técnicas Ambientais da Marinha do Brasil atinentes ao SGA são a NORTAM-02 (Norma técnica ambiental sobre o sistema de gestão ambiental nas Organizações Militares de Terra), NORTAM-04 (Norma Técnica Ambiental sobre Auditoria Ambiental nas Organizações Militares de Terra), e 
NORTAM-06 (Norma Técnica Ambiental sobre Separação dos Resíduos Recicláveis Descartados pelas OM da MB), todas da DPC.

Um exemplo do funcionamento deste sistema foi a auditoria ocorrida no dia 8 de outubro de 2014 (MARINHA, 2015), na Ilha do Centro de Instrução Almirante Wandenkolk (CIAW), figura 3.9, que ocorreu com o fim de se acompanhar os processos de implantação de um Sistema de Gestão Ambiental (SGA) e aprimorar o seu desempenho, bem como verificar as práticas ambientais responsáveis, atualmente aplicadas naquela Organização Militar.

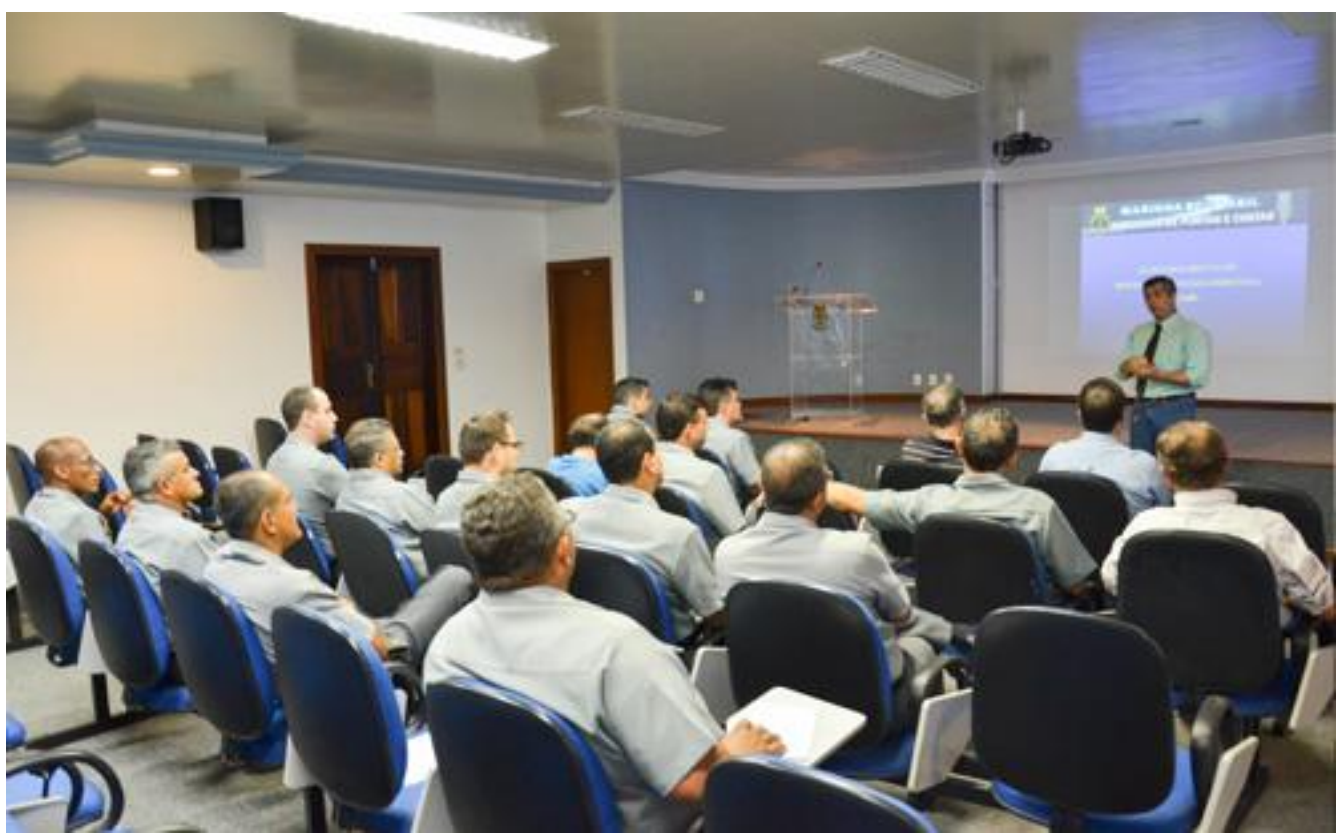

Figura 3.9: Auditoria Ambiental no CIAW. Fonte: http://mar.mil.br.

No exército brasileiro também há esta preocupação, cujas auditorias ambientais são de competência da Diretoria de Patrimônio Imobiliário e Meio Ambiente (DPIMA) e estão em momento de expansão, com a expedição de normas e procedimentos novos, o que representa a constante busca da eficiência administrativa.

Utilizar a auditoria ambiental como ferramenta para evitar ou mitigar os riscos é uma forma imprescindível de implementar uma política ambiental séria e antecipada aos efeitos negativos, com potencial danoso que possam decorrer do desenvolvimento das funções e tarefas militares.

E esta conduta, utilizada dentro dos parâmetros pré-definidos e adequados às normas ambientais e sua política protecionista, pode servir de subsídio documental que seja complementar para a fiscalização externa efetuada por meio 
de órgãos ambientais, nos casos de preparo e emprego das Forças Armadas, com o fim de obter a dispensa do licenciamento.

Isto porque, nestas duas situações - preparo e emprego - diversos empreendimentos militares necessitam utilizar espaços físicos específicos ou recursos naturais limitados, cujas auditorias militares podem ser uma forma de mensurar de forma lógica e racional os limites desta exceção, no intuito de ponderar e equilibrar a defesa das duas garantias constitucionais, valorando os interesses contrapostos, sem impedir a execução da missão das Forças Armadas, nem deixar de promover a proteção ambiental.

Esta filosofia funda-se no princípio da ponderação dos interesses, cujas auditorias ambientais militares seriam um procedimento complementar para apresentar aos órgãos ambientais com o fim delimitar, para cada caso, os parâmetros de equilíbrio entre a necessidade de proteção ambiental e o uso dos recursos naturais para o preparo e emprego da Força, pois um conhecedor das necessidades estratégicas bélicas possui competência para atribuir limitações ou contrapartidas que possam implicar na supressão da própria missão. E, por vezes, a missão não poderá ser executada de outra forma, o que deixa o país em posição de fragilidade em sua segurança nacional. E, por questão de lógica, questiona-se: para quê garantir a manutenção de um parque (ou floresta, ou córrego, etc) se ele pode não te pertencer mais? É este o cerne da preocupação na obtenção da dispensa do licenciamento ambiental nos casos de preparo e emprego da força.

\section{3}

\section{Licenciamento Ambiental e os Empreendimentos Militares de Preparo e Emprego}

A dispensa dos licenciamentos ambientais nas organizações militares emitida pelos órgãos ambientais situa-se em patamar de discussão já que, para executar as tarefas destinadas à Marinha do Brasil, alguns condicionantes ambientais para os licenciamentos podem ser dispensáveis, seja pela urgência, seja pelo sigilo, seja pela idealização estratégica. Lembrando-se, como elencado em item anterior, que a responsabilidade de proteção já deve partir do próprio órgão militar, pois a proteção do meio ambiente é dever constitucional imposto a todos. 
E a dispensa da licença pela fiscalização externa, com o prévio preenchimento de requisitos, no caso específico de preparo e emprego das forças militares, decorre das atividades militares especiais, que necessitam da utilização dos espaços territoriais de forma diferenciada, a demandar interferências sobre a natureza, mas que, certamente, não representam desrespeito à natureza e, sim, a compatibilização entre os interesses constitucionais, o que se diferencia dos licenciamentos comuns, cujo principal fim é a exploração com fins econômicos.

Para haver uma verdadeira compatibilização entre estes interesses, aparentemente opostos, é necessário que se desenvolva um processo cognitivo que reclama tanto a interpretação sistemática das normas em vigor, quanto uma análise perfunctória da omissão legislativa existente, observando-se a necessidade de atuação eficiente e séria do próprio órgão militar. E esta atuação, nos casos de dispensa, precisa ter meios que garantam a proteção ambiental e complementem os processos de dispensa, no que apresenta-se as auditorias e os controles internos para subsidiarem os casos legais previstos de preparo e emprego da força.

Tratar-se-ia de um trabalho exercido de forma colaborativa, como é o caso da competência legislativa comum aos entes públicos. Esta forma colaborativa deve vislumbrar a necessidade de proteger, ao máximo, o meio ambiente, sem eliminar a execução da tarefa constitucional de manutenção da segurança nacional, que tem que ser ponderada diante da alteração do meio ambiente e o resultado esperado de tal intervenção.

Uma boa e eficaz auditoria ambiental militar, e as suas consequentes ações decorrentes, deve subsidiar de forma eficiente as decisões e ações que vão influenciar diretamente um futuro processo administrativo de licenciamento ambiental, quando aplicável ao empreendimento militar, ou delimitar os parâmetros de projeto e execução futura do empreendimento militar, com atividade de preparo ou emprego, que é o caso de dispensa da própria licença ambiental, posto que previsto na legislação.

E essa auditoria é uma forma previdente, já que, além de se preparar para ser fiscalizada, a Organização Militar tem o dever de cumprir as normas ambientais. Neste ponto, há de se avaliar quando e como os licenciamentos ambientais devem ser implementados e quando devem ser dispensados, como no caso dos empreendimentos militares utilizados para o preparo e emprego da força militar. 
Em complemento ao que dispõe o artigo 10, da Lei no 6.938 (BRASIL, 1981), que trata da Política Nacional do Meio Ambiente (PNMA), e que prevê o licenciamento ambiental para empreendimentos e atividades com significativo impacto ambiental de âmbito nacional ou regional, a Resolução $\mathrm{n}^{\mathbf{0}} 237$ (CONAMA, 1997), assim dispõe sobre o licenciamento ambiental:

Art. $1^{\circ}$ - Para efeito desta Resolução são adotadas as seguintes definições:

I - Licenciamento Ambiental: procedimento administrativo pelo qual o órgão ambiental competente licencia a localização, instalação, ampliação e a operação de empreendimentos e atividades utilizadoras de recursos ambientais, consideradas efetiva ou potencialmente poluidoras ou daquelas que, sob qualquer forma, possam causar degradação ambiental, considerando as disposições legais e regulamentares e as normas técnicas aplicáveis ao caso.

Logo, o licenciamento é um procedimento administrativo e um dos instrumentos da PNMA que requer diversas fases e a juntada de tantos documentos quantos forem solicitados para o esclarecimento da questão suscitada.

Ainda, segundo a Resolução nº 237 (CONAMA, 1997):

Art. $2^{\circ}$ - A localização, construção, instalação, ampliação, modificação e operação de empreendimentos e atividades utilizadoras de recursos ambientais consideradas efetiva ou potencialmente poluidoras, bem como os empreendimentos capazes, sob qualquer forma, de causar degradação ambiental, dependerão de prévio licenciamento do órgão ambiental competente, sem prejuízo de outras licenças legalmente exigíveis.

$\S 1^{\circ}$ - Estão sujeitos ao licenciamento ambiental os empreendimentos e as atividades relacionadas no Anexo 1, parte integrante desta Resolução.

Percebe-se do caput do artigo que o empreendedor deve buscar a licença ambiental desde as etapas iniciais do planejamento até a instalação com o início efetivo da operação. No Anexo 1, da referida Resolução, pode-se verificar diversas atividades e empreendimentos que são consideradas efetiva ou potencialmente poluidoras. E assim deve ser já que a exploração dos recursos naturais para a consecução da exploração econômica deve ser delimitada e controlada, para a garantia das gerações atual e futura.

Atuar sem a licença ambiental nos casos obrigatórios pode ensejar mais que a imposição de penalidades pecuniárias. Instalar, ampliar ou atuar sem a licença ambiental é crime, conforme prescrito no art. 60, da Lei $\mathrm{n}^{\mathbf{0}} 9065$ (BRASIL, 1998): 
Art. 60 - Construir, reformar, ampliar, instalar ou fazer funcionar, em qualquer parte do território nacional, estabelecimento os, obras ou serviços potencialmente poluidores, sem licença ou autorização dos órgãos ambientais competentes, ou contrariando as normas legais e regulamentares pertinentes:

Pena - detenção de um a seis meses, ou multa, ou ambas as penas cumulativamente.

Ainda, no que concerne aos empreendimentos que devem ser licenciados sob a competência do IBAMA, a Resolução nº 237 (CONAMA, 1997) dispõe:

Art. $4^{\circ}$ - Compete ao Instituto Brasileiro do Meio Ambiente e dos Recursos Naturais Renováveis - IBAMA, órgão executor do SISNAMA, o licenciamento ambiental, a que se refere o artigo 10 da Lei $n^{\circ} 6.938$, de 31 de agosto de 1981, de empreendimentos e atividades com significativo impacto ambiental de âmbito nacional ou regional, a saber:

V - bases ou empreendimentos militares, quando couber, observada a legislação específica (grifo da autora).

Assim sendo, verifica-se que o órgão competente para as questões de licenciamento ambiental no âmbito das forças armadas é o IBAMA, sendo que se deve observar a legislação específica. Por vezes, a atuação da competência é delegada para o Estado, de acordo com o estabelecido no art. $5^{\circ}$ da Resolução 237 (CONAMA, 1997). Assim, no caso do Rio de Janeiro, por exemplo, a licença passa ao encargo do Instituto Estadual do Meio Ambiente (INEA), cuja norma orientadora estabelece o Sistema de Licenciamento Ambiental do Estado do Rio de Janeiro - SLAM, pelo Decreto Estadual nº 42.159 (RIO DE JANEIRO, 2009).

Conjugue-se, então, as disposições acima com a previsão disposta no art. $7^{\circ}$, da Lei Complementar n ${ }^{\circ} 140$ (BRASIL, 2011):

Art. $7^{\circ}$ - São ações administrativas da União:

XIV - promover o licenciamento ambiental de empreendimentos e atividades:

f) de caráter militar, excetuando-se do licenciamento ambiental, nos termos de ato do Poder Executivo, aqueles previstos no preparo e emprego das Forças Armadas, conforme disposto na Lei Complementar nº 97/1999.

Como se pode observar, há clara previsão de dispensa do licenciamento ambiental nos casos de preparo e emprego das Forças Armadas, o que deve se coadunar com os conceitos descritos na Lei Complementar $n^{\circ} 97$ (BRASIL, 1999), que dispõe sobre as normas gerais para a organização, o preparo e o emprego das Forças Armadas. Essa questão não causa estranheza pois já existem casos de dispensa da licença, como preconizado nas normas ambientais. O que 
parece faltar é a normatização do caso específico de preparo e emprego da força e o reconhecimento oficial deste enquadramento dentro dos órgãos ambientais.

No município do Rio de Janeiro existe a emissão do Requerimento de Certidão de Isenção, que é a forma de obter a dispensa legal nos casos ali previstos. O processo garante a atuação do órgão ambiental sobre os empreendimentos, embora sejam casos de dispensa legal. Então, os casos que se enquadrem nos preceitos dispostos na Resolução SMAC no 453 (Rio de Janeiro, 2008) podem ser submetidos a análise da sua adequação com a consequente dispensa da licença.

Para a adequação ao caso em estudo, a Lei Complementar nº 97 (BRASIL, 1999) esclarece, no que tange ao preparo, em seu $\S 1^{\circ}$, do artigo 13 , que:

Art. 13 - Para o cumprimento da destinação constitucional das Forças Armadas, cabe aos Comandantes da Marinha, do Exército e da Aeronáutica o preparo de seus órgãos operativos e de apoio, obedecidas as políticas estabelecidas pelo Ministro da Defesa.

$\S 1^{\circ}$ - O preparo compreende, entre outras, as atividades permanentes de planejamento, organização e articulação, instrução e adestramento, desenvolvimento de doutrina e pesquisas específicas, inteligência e estruturação das Forças Armadas, de sua logística e mobilização.

Já o emprego está estabelecido no art. 15, da Lei Complementar 97 (BRASIL, 1999), que informa que na defesa da pátria, na garantia dos poderes constitucionais, da lei e da ordem, nas operações de paz, ou seja, no exercício de suas atribuições constitucionais, dependerá de determinação específica do Presidente da República ao Ministro de Estado da Defesa, que ativará os seus órgãos operacionais. Neste campo, verifica-se que depende de normas a serem expedidas em caráter extraordinário, uma norma aberta que dependerá da interpretação do exercício da autoridade da Presidência da República, autoridade maior das Forças Armadas.

Perceba-se que não basta a definição de emprego e preparo disposta na Lei Complementar $n^{\circ} 97$ (BRASIL 1999), que traz normas gerais sobre estas ações militares. Conforme disposto no art. $7^{\circ}$, da Lei Complementar $n^{\circ} 140$ (BRASIL, 2011), a norma carece de ato do Poder Executivo para que receba a devida eficácia, ou seja, para que se defina quais são os casos específicos a serem considerados excluídos do licenciamento ambiental. 
Ora, como estabelecer estes limites de forma a mensurar o que é um empreendimento militar com a atividade de preparo? E quando o empreendimento militar estará sendo empregado em conformidade com a sua destinação?

Em estudo efetuado por DA CRUZ (2014, p.31), citando classificação de RIBAS, as Organizações Militares forma agrupadas em 3 (três) distintos segmentos, com o fim de analisar o seu potencial danoso para definir a aplicação das auditorias ambientais, a saber:

- construção de aquartelamentos e de instalações militares;

- atividades de rotina e administrativas; e

- preparo e emprego da tropa.

No primeiro caso, construção de aquartelamentos e de instalações militares, DA CRUZ (2014, p.33) informa que a conformidade legal se concentra na legislação para a obtenção do licenciamento ambiental; no segundo caso, atividades de rotina e administrativas, pode-se aplicar a legislação correlata do meio civil e, no terceiro caso, preparo e emprego da tropa, não havendo legislação específica, cabe avaliação criteriosa de como devem ser aplicadas as normas ambientais.

No presente estudo, propõe-se uma divisão tripartite diferenciada àquela indicada por DA CRUZ (2014, p.33), devendo-se observar uma interpretação sistemática das normas, com o fim de delinear um caminho a ser definido com as definições mais precisas dos casos de dispensa legal, para ser inserido em um texto de proposição de ato normativo do Poder Executivo, que, no caso, não prevê a chefia do Poder Executivo, podendo, então, ser tanto um Decreto Presidencial quanto um ato normativo emanado do próprio Ministro da Defesa.

\section{4}

\section{Dispensa do Licenciamento Ambiental nos Empreendimentos Militares de Preparo e Emprego}

Para se definir a dispensa do licenciamento ambiental, nos casos do emprego e preparo da Força, deve-se tomar como a principal premissa que a finalidade do licenciamento é a proteção do meio ambiente. Logo, a regra é o licenciamento dos empreendimentos militares, desde que se enquadrem nos casos previstos no Anexo 1, da Resolução no 237 (CONAMA, 1997). 
Neste anexo se pode verificar as atividades que o legislador entendeu ser ação de potencial danoso ao meio ambiente, sendo que, no caso dos empreendimentos militares, a competência originária é da União, ou seja do IBAMA.

Segundo o art. $6^{\circ}$, da Lei n 6.398 (BRASIL, 1981) - PNMA, o IBAMA integra o Sistema Nacional do Meio Ambiente, órgão que deve analisar as atividades com significado impacto ambiental de âmbito nacional ou regional. Portanto, quando há pequeno ou médio impacto, em regra, o IBAMA delega a competência para os Estados. É importante observar que as atividades descritas nos diversos anexos, seja no Anexo VIII, da PNMA, seja no Anexo I, da Resolução nº 237 (CONAMA, 1997), todas são referentes ao contínuo uso dos recursos naturais, a maioria ligada às atividades industriais ou de qualquer outra exploração econômica. Isso é uma situação que se difere dos empreendimentos militares, pois que, na maioria dos casos, ou é a instalação de uma Organização Militar Terrestre para o uso de seu pessoal, seja com fins administrativos ou operativos, ou é uma construção de cais ou carreira, para a manutenção e atracação dos meios navais. Tanto uma, quanto outra situação são de ações que implicam minimamente na exploração do espaço físico utilizado, ou alteração da disponibilidade dos recursos naturais, como a retirada de uma árvore.

Aliás, nas diversas Organizações Militares, assim como outros tantos órgãos públicos com grandes áreas sob a sua propriedade, verifica-se uma vasta área verde, raridade em muitas zonas urbanas, o que representa a importância dada à conservação e preservação destes espaços. Decerto, pode-se afirmar que a maioria dos terrenos da Marinha do Brasil permanecem causando um mínimo impacto de devastação das florestas, matas e rios, muito menos que qualquer outra instituição privada e, quiçá pública.

A assertiva acima tem fundamento no estudo efetuado por YAMAMURA (2009, p.164) sobre as áreas verdes da Marinha do Brasil no Rio de Janeiro, são apresentadas diversas Organizações Militares, situadas tanto na metrópole quanto em distâncias mais consideráveis, como Arraial do Cabo e São Pedro D’Aldeia, que possuem áreas bastante preservadas e que representam a importância destinada para a preservação ambiental, o que implica na constatação da seriedade no trato das construções e ampliações, ou seja, nas intervenções que ali foram executadas. 
No Complexo Guandu do Sapê, por exemplo, aonde se situa o Batalhão de Operações Especiais (BATOP), há uma área total de 4.559.643,10 $\mathrm{m}^{2}$, e desta área 99\% da área total é verde, sem qualquer interferência do homem, com rio e matas ciliares originais. Uma Organização Militar muito próxima ao centro urbano é a Base de Hidrografia da Marinha (BHMN), localizada na Rua Barão do Jaceguai, bem no centro de Niterói. De seus $361.750,00 \mathrm{~m}^{2}$, preserva ainda $39 \%$ desta área total. Outra Organização Militar fica no Complexo Naval de Caxias, o Centro de Adestramento Almirante Marques de Leão (CAAML), em Parada de Lucas. Possui uma área total $\mathrm{d} 16.000 \mathrm{~m}^{2}$, com $40 \%$ deste total exclusivamente com área verde. No Complexo Naval da Ilha das Flores, temos uma área total de $2.070 .492 \mathrm{~m}^{2}$, sendo que desta área total, $73 \%$ é de área exclusivamente verde.

Muito mais exemplos podem ser vistos ao longo do estudo feito por YAMAMURA (2009, p.264), e fica claro que as atividades exercidas pela Marinha do Brasil causaram ínfimo impacto nas áreas que a ela foram destinadas ao uso e guarda. Em todo o Rio de Janeiro, áreas verdes com igual nível de preservação somente podem ser observadas em áreas declaradas legalmente protegidas, como os Parques e APA's. Como conclusão lógica verifica-se que , no caso das Organizações Militares, resta claro que a interferência é apenas para suprir o necessário para a sua atividade fim e atingimento da missão, e nunca para a exploração econômica, o que faz uma forte condição distinta da regra geral, o que a faz uma exceção. E toda exceção deve ser tratada como tal, com normas diferenciadas. E tal situação já tem preceito normativo, ainda que sem aplicabilidade em ação, para situar casos específicos como dispensa legal analisada pelos órgãos ambientais.

Assim, a despeito das atividades do Anexo 1, da Resolução no 237 (CONAMA, 1997), o que importa é verificar quais as atividades que estão afetas ao preparo e emprego da força, já que, nestes casos há a previsão de dispensa dos licenciamentos ambientais pelos órgãos ambientais. Essa particularidade deverá também ser regulamentada pelos órgãos ambientais, como no caso da Resolução SMAC n 453 (Rio de Janeiro, 2008), que trata das dispensas ambientais e seu procedimento. Para que haja efetividade na definição do que seria preparo e emprego da força, apresenta-se uma análise de seu conteúdo.

Efetuando-se uma repartição das atividades das Organizações Militares e tomando-se como parâmetro inicial o constante na pesquisa de DA CRUZ (2014, 
p.52), adotando-se os 3 (três) distintos segmentos, com as devidas adaptações, e com a perspectiva de que o cumprimento das tarefas militares não tem como preceito a exploração constante dos recursos naturais, propõe-se a seguinte aplicação do licenciamento ambiental, conforme figura 3.10:

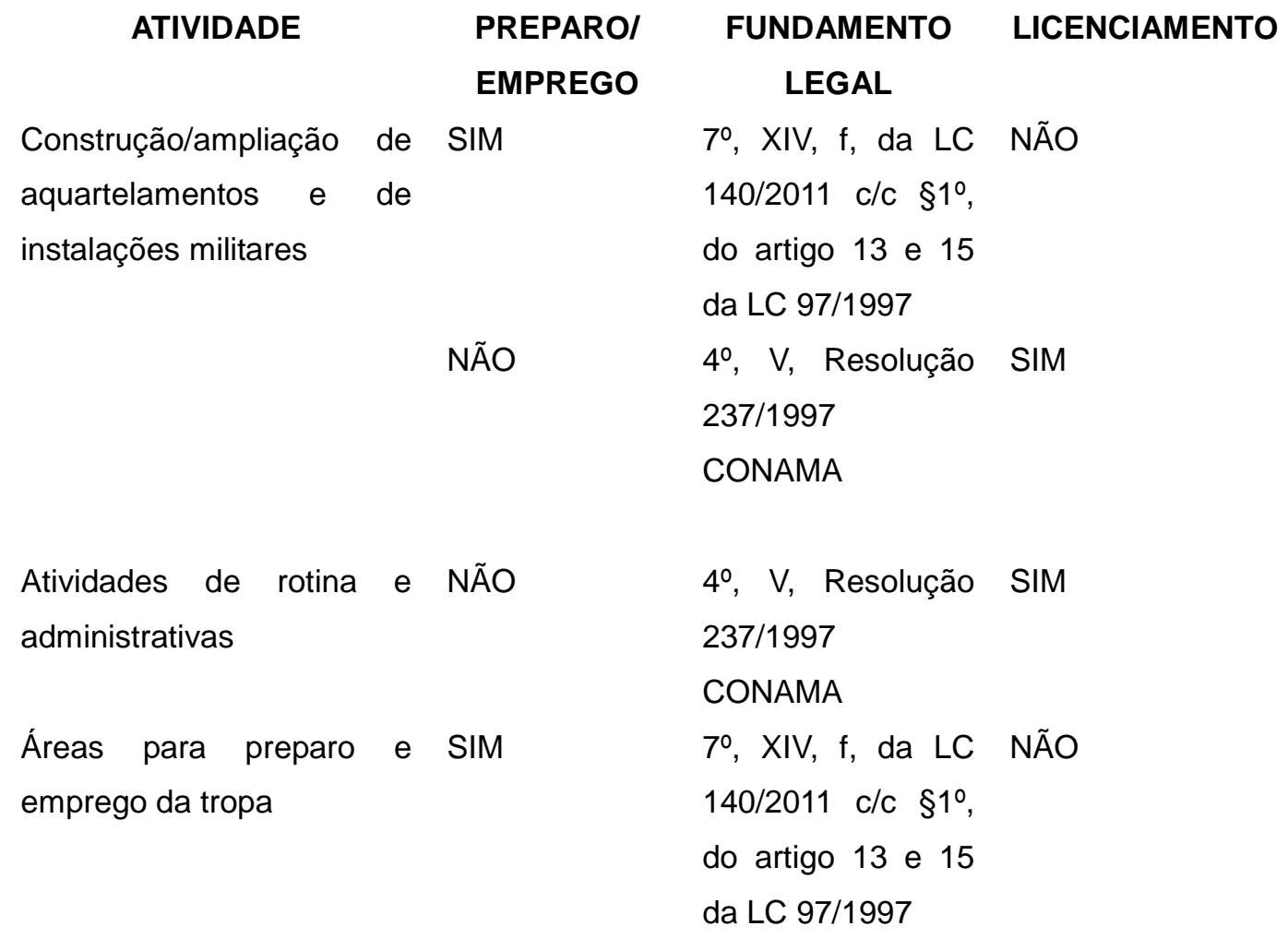

Figura 3.10: Quadro de atividade x preparo/emprego. Fonte: a autora.

Do quadro acima, pode-se tecer algumas conclusões e sugestões. Primeiramente, deve-se atentar para a atividade que está sendo desenvolvida naquela Organização Militar. Observa-se que mais de uma atividade pode ser desenvolvida e, portanto, cada empreendimento dentro do Complexo Militar deverá ser analisado individualmente, mas sem se afastar do contexto de sua principal atividade.

Além disso, havendo algum impacto no meio ambiente, deverão ser observadas se haverá necessidade de contrapartidas para a recuperação ambiental, a fim de minimizar o impacto que, de toda forma, haverá de ser muito menor que qualquer empreendimento com o fim de exploração econômica, pois que, em regra, trata-se de uso limitado de espaço físico. Este projeto deverá respeitar a flora e a fauna existentes e utilizar de uma arquitetura sustentável e responsável como base para todo e qualquer planejamento. 
No que tange ao preparo e emprego, além do constante nos art. 13 e 15 da Lei Complementar n ${ }^{\circ} 97$ (BRASIL, 1999), é necessário que seja expedido um ato normativo do Poder Executivo que defina melhor quais atividades militares assim são consideradas. Isto de forma clara como ocorre no Anexo 1, da Resolução ${ }^{0}$ 237 (CONAMA, 1997). Esta classificação e identificação é necessária para que não ocorra um critério subjetivo. Nos casos de construção/ampliação de aquartelamentos e de instalações militares, por exemplo, verifica-se um critério subjetivo, pois estas ações podem ser impactantes e ter alto grau de degradação ambiental. Portanto, classificar adequadamente o tipo de empreendimento, dentro do preparo e emprego da força, é fundamental para que se enquadre os casos de dispensa do licenciamento pelo órgão ambiental.

Um exemplo da dificuldade encontrada hoje é a construção de um galpão para a guarda de helicópteros. Não resta dúvida de que este galpão é necessário para apoiar toda a logística que acompanha a aquisição dos respectivos helicópteros. Os helicópteros são necessários para o emprego da força e a sua guarda é requisito para que este seja efetivo. Se a sua guarda for impedida, a existência do próprio helicóptero é afetada. E o meio de defesa (helicóptero) é eliminado. Portanto, a guarda é um elemento intrínseco à defesa nacional, ou seja, ao emprego da força. Desta forma, a classificação deve ser fundamentada, a decisão da localização motivada, nada pode ser apenas declarado, mas bem demonstrado. E cabe às forças armadas essa demonstração e ao órgão fiscalizador analisar se este processo é ou não caso de dispensa.

Tudo deve ocorrer dentro de um parâmetro normativo, que é o ato normativo que indica o que é ou não preparo ou emprego. E mais. Deve haver um documento administrativo que assim o classifique como preparo ou emprego.

Nos casos de atividades de rotina e administrativas, não resta dúvida que nada tem de emprego e preparo, mas também cabe ao ato normativo deixar claro quais são as atividades de rotina e administrativas, que usualmente são atividades em que ocorrem atividades de escritório ou exercícios físicos não-operacionais, agregando valor intelectual e apoiando as atividades fins.

Por fim, as áreas destinadas ao emprego e preparo da força, certamente, são consideradas dentro dos casos de dispensa dos licenciamentos ambientais, devendo ser complementada a sua definição, já contida nos artigos 13 e 15 da Lei Complementar $\mathrm{n}^{\circ} 97$ (BRASIL, 1999) de forma incompleta. 
Ainda no que se relaciona à omissão legislativa, o ato a ser emanado do Poder Executivo há de ser um ato normativo para todas as Forças Armadas, a fim de não causar decisões distintas para situações análogas. Assim, tanto pode emanar do Chefe Supremo das Forças Armadas, como disposto no art. $1^{\circ}$ da Lei Complementar no 97 (BRASIL, 1999), por meio da expedição de um Decreto, quanto pode emanar do seu superior hierárquico, o Ministro de Estado da Defesa, por meio de uma Resolução ou qualquer outro ato administrativo que seja de sua competência, conforme o art. $3^{\circ}$ da referida Lei complementar.

Como a falta da norma impede a decisão fundada em regra escrita, resta manter-se atento à missão e tarefa executada em cada Organização Militar, porquanto cada empreendimento haverá de ter uma destinação específica, para uma tarefa específica. Com esta destinação específica para o empreendimento, há de se submeter a uma análise crítica e imparcial sobre a sua interação com a definição de emprego e preparo, já estabelecidos nos artigos 13 e 15, da Lei Complementar $n^{\circ} 97$ (BRASIL, 1999), para que seja bem demonstrada no processo de dispensa no órgão ambiental.

Além de serem juntados os documentos sugeridos acima, como histórico fotográfico, da biologia existente, de auditorias ambientais, dentre outros, é importante que durante o desenvolvimento do empreendimento dispensado da licença haja o acompanhamento com relatórios fotográficos do que existe na área desde o início da execução das atividades de interferência no meio ambiente, a fim de manter-se um arquivo tanto para fins históricos, quanto para o controle atuante na preservação do meio ambiente. E certamente, ao órgão ambiental caberá a atuação de controle se há ou não desvio da finalidade da dispensa, ato administrativo que direcionará a interferência sobre os recursos naturais, com o acompanhamento do desenvolvimento do empreendimento, que deverá estar sempre vinculado aos seus motivos que determinaram a sua necessidade. 


\section{4 \\ MODERNIZAÇÃO DO SISTEMA DE ESGOTO DA MARINHA DO BRASIL}

\section{1}

\section{Aspectos Gerais}

Segundo dados levantados no Departamento de Planejamento da Diretoria de Obras Civis da Marinha, por meio dos responsáveis que ali trabalham, como o Engenheiro Abrahão e o Engenheiro Haroldo, aproximadamente 70\% (setenta por cento) dos efluentes advindos das edificações navais espalhadas por todo o Brasil têm as fossas sépticas como o sistema de tratamento dos efluentes, acrescidas, em quase sua totalidade, por tratamento complementar na forma de filtro anaeróbico.

Além disso, um grande percentual destas edificações está localizado em terrenos que se encontram muito próximo de rios e mares, na maioria das vezes em cotas abaixo do nível do mar. Esta situação facilita a ocorrência do fenômeno de refluxo pelas tubulações de descarte de esgoto. Também facilita a ocorrência de alagamento dos terrenos, seja pela ocorrência de marés altas, seja por chuvas de grande vazão, o que dificulta o lançamento dos efluentes para os corpos receptores.

Neste momento de escassez de água e contaminação dos corpos receptores, faz-se necessário que se executem reformas, ampliações e novas construções para que o sistema de esgoto alcance o correto desempenho esperado, porque além dos aspectos hidráulicos, também se deve considerar os aspectos de sustentabilidade e atualidade técnica, que propõe melhor eficiência e menor custo de manutenção.

A qualidade do esgoto sanitário, ou seja, o despejo líquido constituído de esgotos doméstico, industrial, água de infiltração e a contribuição pluvial parasitária, como citado por DE ARAUJO e NEVULARI (2012, pg. 37), é de suma importância para o meio ambiente e para a saúde do homem. Por isso, o seu tratamento e a sua disposição no meio ambiente deve ser cuidadosamente gerida, a fim de que se possa minimizar os impactos quando para ele são devolvidas. 
E tudo isso se dá com a concepção de um escoamento livre e permanente, em conformidade com DE ARAUJO e NUVOLARI (2012, p.49), onde não fique depositada a matéria orgânica nas tubulações e, ao mesmo tempo, este material deve ser controlado e tratado no retorno ao meio ambiente. $E$ isto ocorre quando a vazão é constante ao longo do fluxo, no sentido longitudinal do tubo, com uma declividade única, além da forma e da rugosidade, com velocidade constante.

Como esclarecem SOBRINHO e TSUTIYA (2000, p. 89)

Os materiais sólidos encontrados no esgoto consistem de partículas orgânicas e inorgânicas. Devido ao efeito da gravidade, qualquer dessas partículas com densidade maior que a da água tenderá a depositar-se nas tubulações de esgoto.

Também a NBR 8160 (ABNT, 1999), que trata dos sistemas de esgotos prediais, é rigorosa quando prevê que o tratamento nas unidades deve ser efetuado de forma a não ocorrer prejuízo ao meio ambiente. Veja-se:

3.17 dispositivos de tratamento de esgoto: Unidades destinadas a reter corpos sólidos e outros poluentes contidos no esgoto sanitário com o encaminhamento do líquido depurado a um destino final, de modo a não prejudicar o meio ambiente.

Diante desta situação, resta claro que a modernização do sistema de esgoto da Marinha do Brasil requer uma priorização, não somente no que concerne ao controle da qualidade do despejo dos resíduos nos corpos receptores, mas que comporte também a necessidade decorrente de implementar uma rigorosa manutenção dos seus dispositivos, como as fossas e filtros, elementos presentes de forma constante nos projetos de esgoto sanitário.

Além disso, também se deve priorizar a execução das obras para a efetivação de ligações do sistema à rede pública, quando estas estão disponíveis ou estão próximas de serem concluídas, já que, embora exista o Programa de Modernização do Setor Saneamento (PMSS) para os Estados, como consta no Ministério das Cidades (GOVERNO FEDERAL, 2015), na prática ainda há déficit da disposição do serviço público para toda a população.

Segundo dados obtidos no Sistema Nacional de Informações sobre Saneamento - SNIS (Ministério das Cidades, 2016), ainda há necessidade de implantação de tratamentos de esgoto pelo país. Assim, tem-se índices de atendimento urbanos variáveis. 
Dados do SNIS de 2014 indicam que:

- na região norte verifica-se índice médio menor que 10\%;

- na região nordeste 50\% em média;

- na região centro oeste entre 40 e $70 \%$;

- na região sul entre 20 a 40\%; e

- na região sudeste em torno de $70 \%$.

Em verdade, muitos programas públicos são colocados no papel, mas não se materializam e, no caso do saneamento ainda há uma lamentável realidade por todo o Brasil, não se esquecendo que a localização de muitas das Organizações Terrestres é em localidades de baixa renda, com quase nenhum ou nenhum tipo de saneamento, sequer as fossas, pois nestas comunidades ainda existe a triste realidade dos sumidouros, valas abertas que causam mau cheiro, doenças e maltratam o meio ambiente.

\section{2}

\section{O Sistema Público de Coleta de Esgoto}

$\mathrm{Na}$ federação, a execução das redes de esgoto fica sob a responsabilidade da municipalidade, logo, os esgotos prediais, são, ou deveriam ser, lançados na rede de esgotos da cidade. Esclareça-se que o país adotou o sistema federativo, dividindo as prestações de serviços pelos três entes da federação, Município, Estado e União. As situações locais são ligadas ao Município, as regionais ao Estado e as nacionais à União. Assim, segundo o artigo 30, inciso V, da Constituição da República Federativa do Brasil, cabe ao Município organizar e prestar, diretamente ou sob regime de concessão ou permissão, os serviços públicos de interesse local, incluído o de transporte coletivo, que tem caráter essencial.

Entretanto, nem sempre a realidade de disponibilidade de redes públicas existe em inúmeras cidades no Brasil. Embora quase a totalidade de Municípios disponham de redes públicas, no seu interior a solução em alguns bairros afastados, por vezes, é o envio direto para o solo. E o envio é efetuado por meio de buracos escavados a céu aberto que escoam os efluentes e não permitem qualquer tipo de tratamento, nem mesmo uma realização de reações orgânicas que diminuam a carga de bactérias nos efluentes antes de serem despejados no meio 
ambiente. E muito desse processo independe do Estado, mas de uma educação ambiental de responsabilidade ambiental.

Além disso, a carga bacteriológica carreada expõe a população a doenças variadas. Sob o foco da sustentabilidade, o despejo de efluentes sem tratamento diretamente nos rios e nos mares contaminam diretamente estes locais, o que é algo inimaginável nos dias de hoje em que existe informação, técnicas e equipamentos acessíveis que impedem ou diminuem este impacto no meio ambiente. Este fato, como citado, é agravado pela falta de educação ambiental, que é um reflexo da nossa realidade social. Nos lançamentos das águas residuais industriais ocorrem lançamentos diretos clandestinos sem o adequado tratamento prévio, o que é um desrespeito às normas ambientais sem a mínima precaução e prevenção, a despeito da árdua e contínua missão de fiscalização pelos órgãos ambientais, que multam e suspendem as suas licenças.

Segundo o Diagnóstico de Serviços de Águas e Esgotos dados disponíveis no Sistema Nacional de Informações sobre Saneamento - SNIS (Ministério das Cidades, 2016), verifica-se que os municípios brasileiros possuem 586,2 mil quilômetros de redes de água, às quais estão conectados 51,6 milhões de ramais prediais. Em termos de esgotamento sanitário, são 270,7 mil quilômetros de redes, às quais se conectam 27,6 milhões de ramais prediais. Em 2014, verifica-se um bom crescimento dos sistemas brasileiros na comparação com o ano de 2013, sendo detectados novos 2,0 milhões de ramais na rede de água e 1,2 milhão na rede de esgotos, crescimentos relevantes quando se trata de ampliação de sistemas complexos nas cidades brasileiras, que correspondem a aumentos de 4,0\% e 4,7\%, respectivamente. Lembrando-se que mesmo que um Município seja atendido por rede de esgoto pública, isto não significa que a sua totalidade esteja atendida, ou seja, que a rede de esgoto pública tenha chegado a todas as edificações e construções daquele Município.

Ainda segundo o citado diagnóstico, no que concerne ao atendimento por redes de esgotos, o contingente de população urbana atendida alcança 96,8 milhões de habitantes, um incremento de novos 3,5 milhões de habitantes atendidos, crescimento de 3,7\%, na comparação com 2013. Já o índice médio de atendimento é de 57,6\% nas áreas urbanas das cidades brasileiras, destacando-se a região Sudeste, com média de $83,3 \%$. 
No que se refere ao tratamento dos esgotos, observa-se que o índice médio do país chega a 40,8\% para a estimativa dos esgotos gerados e 70,9\% para os esgotos que são coletados, sendo que o volume de esgotos tratados saltou de 3,624 bilhões de m3 em 2013 para 3,764 bilhões de m3 em 2014, correspondendo a um incremento de $3,9 \%$. É um crescimento lento, porém encaminhando-se para a eliminação do déficit.

No ano de 2007, finalmente materializou-se a Lei $\mathrm{n}^{\circ} 11.445$ (BRASIL, 2007), a qual contém o conceito de saneamento básico que é o conjunto de serviços, infraestruturas e instalações de abastecimento de água, esgotamento sanitário, limpeza urbana e manejo de resíduos sólidos e drenagem de águas pluviais urbanas.

Com o advento desta lei, nasceu a obrigatoriedade da União de elaborar um plano dispondo sobre o saneamento básico para o País, sendo que este plano seria um guia que contivesse as diretrizes para os Planos Básicos Municipais de Saneamento. Assim, o Governo Federal, sob a coordenação do Ministério das Cidades, elaborou o Plano Nacional de Saneamento Básico (Plansab), aprovado em 2013, mediante o Decreto Presidencial $n^{\circ} 8.141$ (BRASIL, 2013), complementado por uma Portaria Interministerial, de $\mathrm{n}^{\circ} 571$ (BRASIL, 2013), firmada por sete Ministérios.

A Lei $\mathrm{n}^{\circ} 11.445$ (BRASIL, 2007), também introduziu a obrigatoriedade da elaboração de um Plano Municipal de Saneamento Básico, conforme transcrevese abaixo:

Art. $9^{\circ}$ - O titular dos serviços formulará a respectiva política pública de saneamento básico, devendo para tanto:

I - elaborar os planos de saneamento básico, nos termos dessa lei;

Art. 11 - São condições de validade dos contratos que tenham por objeto prestação de serviços públicos de saneamento básico:

I - a existência de plano de saneamento básico

Segundo o MINISTÉRIO DAS CIDADES (2016), no ano de 2015 já se atingiu uma redução das perdas de água para 37\% em 2013. Em relação ao percentual de esgotos tratados com relação aos esgotos coletados, já foi atingido um percentual de cerca de $70 \%$.

Interessante, ainda, é analisar as metas apontadas. Com o Plano Nacional de Saneamento Básico (Plansab), disponível no MINISTÉRIO DAS CIDADES (2015), há a previsão de que o Governo irá alcançar, nos próximos 20 anos, o 
atendimento de todos a universalização do abastecimento de água em áreas urbanas, até 2023; a universalização da coleta de resíduos sólidos urbanos, em áreas urbanas, até 2033; e alcançar, em 2033, 92\% de domicílios urbanos servidos por rede coletora de esgotos sanitários ou fossa séptica e atingir 93\% de tratamento do esgoto coletado.

Segundo o Plano Nacional de Saneamento Básico, o sistema de esgoto está distribuído conforme figura 4.1:
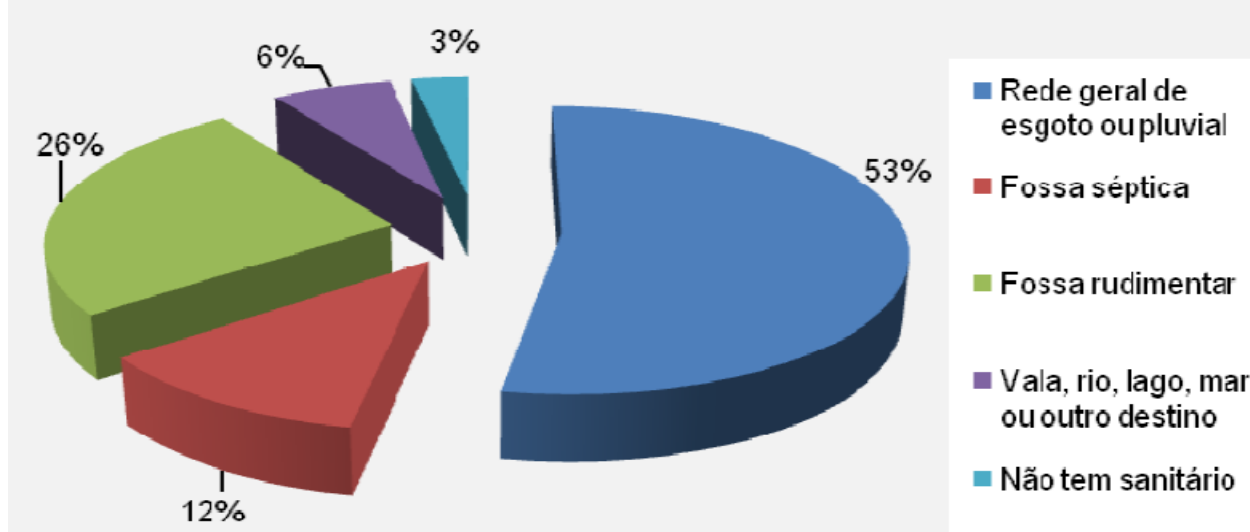

Figura 4.1: Distribuição nacional do sistema de esgoto. Fonte: Dados obtidos do Censo do IBGE no ano de 2011. MINISTÉRIO DAS CIDADES (2015).

Ainda neste Plano, conforme figura 4.2, verifica-se que aproximadamente metade da população do País dispõe de esgotos domésticos em rede coletora de esgotos ou em redes de águas pluviais e 20 milhões se utilizam de fossas sépticas. Os demais despejam diretamente nos corpos receptores sem qualquer cuidado com o meio ambiente e com a própria saúde.

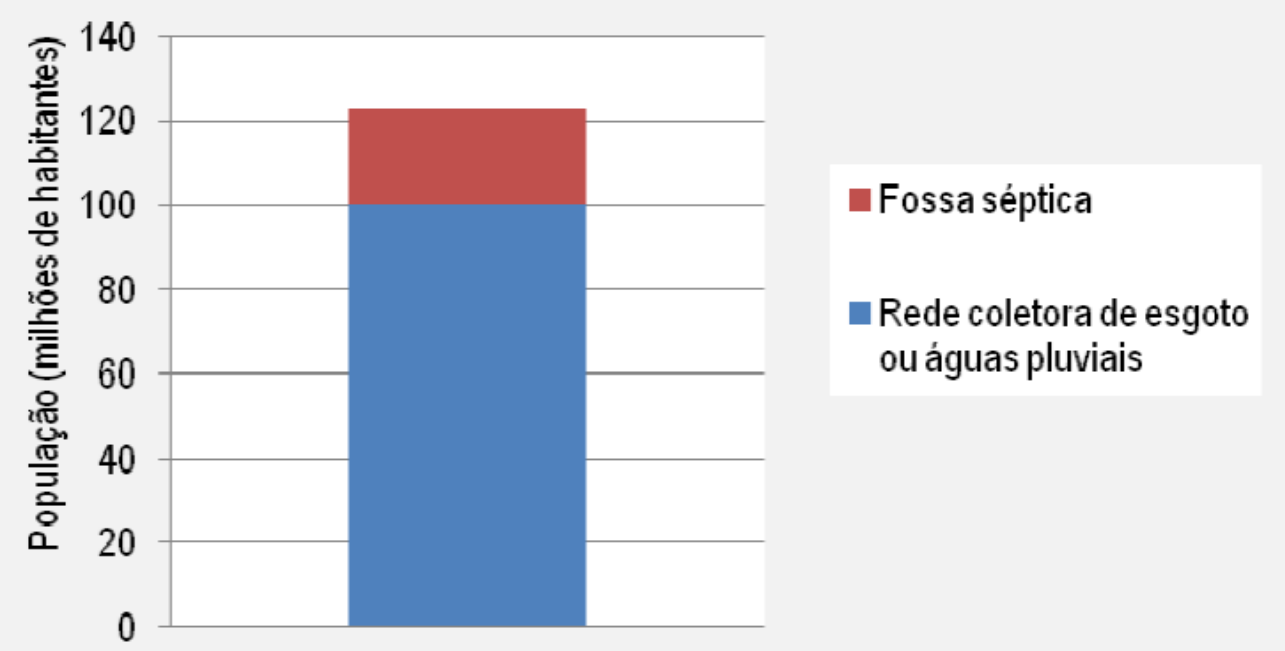

Figura 4.2: Distribuição da coleta de esgoto (fossa séptica e rede coletora pública). Fonte: Dados obtidos do Censo do IBGE no ano de 2011. MINISTÉRIO DAS CIDADES (2015). 
Por tudo acima, pode-se verificar que o esgotamento sanitário é um instrumento de melhoria para a sociedade, relacionando-se com outras disciplinas como a sociologia, a biologia, o direito e a medicina, e que deve ser efetuado com a devida seriedade e controle, cabendo aos quartéis da Marinha do Brasil cumprirem com a sua obrigação de tratar os efluentes de esgoto nos lugares aonde não há rede pública.

\section{3}

\section{O Sistema de Tratamento e Descarte dos Efluentes}

Segundo BRITTO (2004, p. 24), tratar esgotos não é fazer passar os efluentes por uma estação do tratamento ou fazê-los passar por uma tubulação e lançá-los em águas marinhas ou outro corpo receptor qualquer. $\mathrm{O}$ autor afirma que:

Tratar esgotos é adequar convenientemente os efluentes sanitários os corpos receptores, ou seja, é criar condições para que os efluentes sanitários ao serem lançados aos corpos receptores não causem impactos ambientais significativos. Entende-se por impactos ambientais significativos aqueles que modificam as características físicas, químicas e biológicas do corpo receptor em uma determinada área.

Um sistema de tratamento e descarte dos efluentes deve também considerar a sua importância no contexto multidisciplinar que o acompanha. Como citado por DE ARAUJO e NUVOLARI (2012, p.255):

é prática aconselhável que o lançamento seja feito de maneira criteriosa, após um pré-tratamento (remoção de sólidos grosseiros e areia), e conduzidos por emissários que levem esse esgoto até um ponto onde seu lançamento não prejudique estética e sanitariamente um eventual uso dessa água para lazer de contato primário. Com isso, quer-se dizer que o nível de tratamento sempre vai depender da análise das condições locais.

Como se pode depreender do texto acima, o importante é necessário que se análise caso a caso, pois os rios e mares possuem um processo próprio que pode absorver a carga orgânica, mas até um limite de acordo com a sua vazão. Continua DE ARAUJO e NUVOLARI (2012, p. 255) esclarecendo que dependendo da relação entre a carga poluente lançada e a vazão do corpo receptor a variação da qualidade da água pode ou não ser significativa. 
A capacidade de absorção da carga orgânica pelos corpos receptores denomina-se autodepuração. Segundo BRITTO (2004, p. 27):

\begin{abstract}
Um corpo d'água em seu estado natural constitui-se em um ecossistema. Nele coexistem numerosos organismos que se relacionam entre si e com o próprio ambiente. Quando a relação é entre seres vivos ela é chamada de ecobiose. Qualquer modificação introduzida seja nas espécies vivas, seja no ambiente, pode ter consequências que se refletem em todo o conjunto, rompendo o equilíbrio ecológico... Ao lançamento em um corpo líquido de uma certa quantidade de esgoto, a avidez desse esgoto por oxigênio, denominada de Demanda Bioquímica de Oxigênio (DBO), irá tender a romper esse equilíbrio. $\mathrm{O}$ aumento do consumo de OD (oxigênio dissolvido na água) causado pelo esgoto irá diminuir o nível de OD no corpo líquido. Caso não houvesse reparação, a tendência seria que esse nível baixasse continuamente, rapidamente à princípio, mais lentamente após, até atingir níveis extremamente baixos. Entretanto, como já vimos, o curso d'água tem uma certa capacidade de recuperar oxigênio. Essa capacidade é em função, entre outros fatores, do próprio teor de $\mathrm{OD}$, sendo mais rápida a aeração quanto maior a diferença entre a saturação e o OD existente no corpo d'água... Como vimos, os cursos d’água após receberem uma carga de poluição sofrem modificações em suas características, mas tendem a restabelecer as condições existentes antes do lançamento dos esgotos. Esta recuperação é conhecida por "autodepuração dos cursos d'água".
\end{abstract}

Embora haja esta capacidade natural de autodepuração, o fato é que o homem já ultrapassou em muito o limite de lançamento de carga orgânica nos rios e lagoas, o que tem sido evidenciado por várias catástrofes naturais como a mortandade de peixes e diminuição das espécies de seres vivos, dentre outras situações que demonstram a importância de proteção do meio ambiente.

Nos casos de tratamento e descarte dos efluentes da Marinha do Brasil essa relação deve ser observada. Assim, todo o esgoto deve ser tratado antes de ser lançado aos corpos receptores, a fim de diminuir ao máximo a carga orgânica neles lançada. Em alguns casos, é necessário um grande sistema com níveis de tratamento diferenciados, como nos casos das Estações de Tratamento de Esgoto; em outros, a instalação de uma fossa séptica pode atender momentaneamente, por ser de baixo custo, como será verificado adiante.

Na Marinha do Brasil, existem regras para dar uma diretriz à gestão do sistema de esgoto, como consta da DGMM-0600, cujo propósito é apresentar as normas e procedimentos técnico-administrativos para o processo de obtenção de instalações terrestres por meio da execução de obras civis na MB. Segundo o prescrito no seu item 2, da Introdução, a norma está dividida em três partes, constituídas da seguinte forma: a primeira parte define a sistemática de Projetos 
de Investimento para a obtenção de instalações terrestres, englobando seis capítulos: o capítulo 1 descreve o propósito, a sistemática, o conceito e a terminologia; o capítulo 2 descreve as fases padronizadas; o capítulo 3 estabelece o detalhamento; o capítulo 4 apresenta as tabelas; e o capítulo 5 apresenta os exemplos de Projetos de Investimento. A segunda parte define os projetos de engenharia e é constituída de cinco capítulos: o capítulo 6 descreve as atividades preliminares para a obtenção do projeto de engenharia; o capítulo 7 descreve as definições e conceitos básicos; o capítulo 8 descreve os procedimentos para a elaboração de projetos; o capítulo 9 apresenta o dimensionamento usual para as edificações da MB; e o capítulo 10 apresenta os modelos exemplificados. A terceira parte estabelece as normas para a fiscalização e o recebimento de obras e serviços de engenharia civil, sendo constituída de quatro capítulos: o capítulo 11 trata das disposições gerais; o capítulo 12 apresenta as normas para a fiscalização de obras civis; o capítulo 13 descreve as instruções para a escrituração do livro de ocorrências; e o capítulo 14 estabelece as normas para o recebimento provisório e definitivo e apresenta os modelos dos termos de recebimento provisório (TERP) e definitivo (TERD).

Segundo a norma, o planejamento deve observar a dinâmica do Sistema do Plano Diretor (SPD), inclusive focalizando as atividades relacionadas com o controle da ação planejada para o acompanhamento físico-financeiro do Plano de Ação, atualizando um sistema específico de controle denominado SIPLAD. A ideia é que exista um detalhamento da realização físico-financeira dos Projetos, identificando as condições de execução de cada parcela e permitindo seu acompanhamento conforme o Sistema do Plano Diretor (SPD), realizando um controle efetivo entre os custos e os planos de ação.

Em uma escala mais simples, o fato é que o gerenciamento da verba tem que ser controlado. E neste controle deve ser prevista a necessidade de modernização do sistema e a manutenção deste, contendo, no mínimo, a previsão da expansão do sistema em decorrência do aumento de população e as limpezas anuais das fossas sépticas, meio de tratamento dos efluentes que é o mais utilizado até a presente data, embora necessite de uma modernização de forma célere para que aumente a eficiência do sistema de esgoto existente. 


\subsection{1}

\section{Considerações Gerais}

O sistema de tratamento e descarte dos efluentes na Marinha do Brasil é permeado por questões políticas e orçamentárias, além, é claro, da sua própria limitação de efetivo, que se dividem em responsáveis pela execução de projetos e responsáveis pela fiscalização das obras. Os projetos servem para subsidiar as inúmeras licitações públicas, meio legal de contratação do órgão público, que surgem conforme a necessidade de terceirização da execução das obras e projetos.

As normas que regem o sistema de coleta e descarte dos efluentes abrangem tanto a execução detalhada do tipo de sistema, materiais, quanto a observância das leis ambientais. Conforme citado por MACINTYRE (2012, p.85), as prescrições relativas às instalações prediais de esgotos sanitários variam em nosso país conforme as municipalidades. Todas, porém, procuram seguir fundamentalmente as normas da ABNT, como no caso da NBR 8160 (ABNT, 1999), que fixa as condições técnicas exigíveis para o projeto e a execução das referidas instalações de esgoto.

No caso das edificações nos quartéis da Marinha do Brasil as regras utilizadas constam da referida norma NBR 8160 (ABNT, 1999), nela abrangendo tanto o dimensionamento para projetos quanto a execução dos serviços de obra, reforma e ampliação. Também se observam as normas de tratamento de esgoto, como a NBR 7229 (ABNT, 1993) e a NBR 13969 (ABNT, 1997), que trata da reinserção no meio ambiente dos efluentes tratados, além das demais normas especiais editadas pelos próprios quartéis, com a denominação de normas técnicas administrativas, como as OBRASMARINST, emitidas pela Diretoria de Obras Civis da Marinha e as DGMM, emitidas pela Diretoria Geral de Materiais da Marinha.

A qualidade não abrange somente o controle de seu despejo, mas também a responsabilidade na concepção e execução do projeto de esgoto, que, por si só, estabelecerá todo o fluxo, trajeto e cuidado com os efluentes das edificações. Segundo SOBRINHO e TSUTIYA (2000, p. 4-5), no conjunto de atividades que constitui a elaboração de um projeto de um sistema de esgoto sanitário, a concepção é elaborada na fase inicial do projeto. 
A arte de projetar é uma liberdade relativa do seu executor. Isto porque o lançamento de redes de esgoto deve seguir critérios normativos para que exista um atendimento às regras hidráulicas, necessárias ao bom funcionamento do conjunto. Ou seja, deve haver escoamento dos efluentes em um período de tempo que seja proporcional ao espaço destinado para o seu acúmulo ou passagem, o que se relaciona com parâmetros como declividade, tração trativa, regime de escoamento existente, dimensão e comprimento das tubulações, ângulos das passagens efetuadas pelas conexões, tudo para atendimento ao objetivo prescrito no item 1, da norma técnica NBR 8160 (ABNT, 1999), que é a garantia mínima de higiene, segurança e conforto dos usuários, tendo em vista a qualidade dos sistemas.

Além disso, os efluentes de esgotos sofrem grande processo de alteração bacteriológica que provoca a evaporação de elementos químicos contendo alto grau de odor, que deve ser eliminado ao longo da rede. Portanto, a ventilação da rede é tão importante quanto o seu caminhamento. O processo de decomposição dos materiais advindos dos efluentes também devem ser observados no quesito espaço para sua ocorrência, pois detritos advindos de cozinhas, por exemplo, precisam permanecer em processo de decomposição antes de serem lançados na rede, sob pena de desrespeitar o índice de saturação de microorganismos no efluente.

Portanto, ao se lançar os aparelhos sanitários no ambiente projetado em planta não se trata somente de simples escolha arquitetônica, mas de observar a sua exequibilidade e eficiência por meio de requisitos de desempenho, que é composto, segundo o item 3.35 da NBR 8160 (ABNT, 1999), das exigências qualitativas quanto ao comportamento final esperado para o sistema predial.

Segundo JORDÃO e PESSOA (1971, p. 25):

Um sistema qualquer de esgotos sanitários encaminha seus efluentes, direta ou indiretamente, para corpos d'água receptores, formados por conjuntos das águas de superfície e/ou de subsolo. A capacidade receptora destas águas em harmonia com a utilização estabelece o grau de condicionamento que deverá ser submetido o efluente sanitário, de modo que o corpo d'água receptor não sofra alterações dos parâmetros de salubridade fixados para a região afetada pelo lançamento. Os condicionantes aplicados aos esgotos são comumente denominados de processo de tratamento. 
Ainda, citado por DE ARAUJO e NUVOLARI (2012, p. 256), o lançamento de esgoto sanitário sem prévio tratamento, num determinado corpo d’água, pode causar a deterioração da qualidade dessa água, que passaria então a ser uma ameaça à saúde da população. Acrescenta-se que, segundo MACINTYRE (2013, p. 85):

Os esgotos prediais são, ou deveriam ser lançados na rede de esgotos da cidade. Essa rede, que toda a cidade possui ou almeja possuir, pode ser realizada segundo um dos seguintes sistemas:

a) Sistema unitário

b) Sistema separador absoluto: no qual há duas redes públicas totalmente independentes: uma para águas pluviais e outra somente para as águas residuárias (e de infiltração). No Brasil é o sistema adotado, devido às vantagens que apresenta em relação ao sistema unitário, entre as quais a exigência de menor diâmetro das canalizações e menor custo de elevatórias e estações de tratamento.

c) Sistema misto ou separador combinado $\cdots$

\section{Segundo a NRB 8160 (ABNT, 1999):}

4.1.3.1 O sistema predial de esgoto sanitário deve ser separador absoluto em relação ao sistema predial de águas pluviais, ou seja, não deve existir nenhuma ligação entre os dois sistemas.

Assim, nosso sistema é o separador absoluto, o que também ocorre dentro dos quartéis, por se situarem, em regra, em zonas com atendimento pela rede pública, e como ocorre no caso concreto estudado.

Neste sistema, devem ser considerados os critérios de autolimpeza dos coletores. Para tanto, o projeto hidráulico-sanitário das tubulações de esgoto envolve considerações sobre três aspectos principais, como informa SOBRINHO e TSUTIYA (2000, p.86).

... hidráulicos: as tubulações funcionando como condutos livres deverão transportar as vazões máximas e mínimas previstas no projeto;

Reações bioquímicas: controle de sulfetos de hidrogênio;

Deposição de materiais sólidos encontrados no esgoto - ação de autolimpeza.

No que concerne ao aspecto hidráulico, a adoção do método da Unidade Hunter de contribuição (UH) é um método eficiente e simples para a garantia do adequado resultado de dimensionamento das tubulações.

Em relação à autolimpeza é importante ressaltar que, no caso concreto, a limpeza programada das caixas de inspeção é uma ação que deve ser empreendida 
com seriedade e periodicidade, pois a não ocorrência da limpeza pode comprometer todo o sistema de coleta da rede. O mesmo deve ser observado para as fossas sépticas, quando não existir um sistema de coleta para a rede pública ou qualquer outro tipo de tratamento do esgoto.

Para diminuir a quantidade de caixas de inspeção e diminuir as interferências diretas deve-se buscar o traçado das tubulações o mais retilíneo possível, tanto em planta quanto em perfil, para evitar a obrigatoriedade de colocação de caixas de inspeção nas deflexões, como prevê a norma, que tem por fim a limpeza e desobstrução dos trechos a ela ligados.

Nas Organizações Militares da Marinha do Brasil é uma situação comum a inexistência da rede pública de esgoto, conforme dados levantados no Departamento de Planejamento da Diretoria de Obras Civis da Marinha, o que justifica o retrato atual da maioria dos sistemas, mas não impede a busca da modernização do sistema.

Também pode ocorrer a situação de superveniência da disponibilidade de rede de esgoto pública, mas nestes casos há que seja incluída esta necessidade nos Planos Diretores, que serão analisados anualmente e, por conseguinte, efetuada a modernização necessária. Ou seja, ainda que o Município coloque à disposição a rede de esgoto para a coleta dos efluentes gerados, o sistema de coleta existente é mantido até que se proceda a liberação de recursos e os procedimentos administrativos, como a licitação, para que seja efetuada a modernização do sistema. Assim, verificam-se duas situações.

A primeira é a limitação orçamentária, que faz com que seja necessária uma programação da modernização. A União destina anualmente uma determinada verba direcionada para engenharia, que abrange as construções, reformas e modificações nas edificações. Entretanto, esta verba é aprovada por lei e não atende a todas as necessidades reais da Marinha do Brasil. Com a inserção nas leis orçamentárias das metas físicas, o orçamento da obra fica relacionado a ela e, caso haja alguma necessidade superveniente de uma outra obra, a Administração não pode simplesmente trocar a sua prioridade. Necessita solicitar nova verba para a nova obra. Sendo assim, os recursos ficam sempre dependentes da aprovação e hierarquização para o ano seguinte. Esta situação torna a priorização catastrófica, porque as obras de recuperação e reforma, se tornam, em regra, secundárias, diante dos gastos com pessoal e com os meios navais, 
instrumento principal da Marinha de Guerra. Tal fato, contudo, deve ser revisto, já que a modernização do sistema de esgoto é valor a ser agregado à própria saúde da tripulação e de toda a população.

A segunda é a hierarquização das ações na Administração. Sempre que necessário, a Marinha do Brasil deve ter o apoio terrestre nas melhores condições. Entretanto, os meios navais, o que envolve os equipamentos bélicos e o treinamento de pessoal para os exercícios de suas tarefas militares, são o principal motivo da existência da Marinha do Brasil, cuja finalidade é a garantia da defesa nacional, dos poderes institucionais e garantidor da lei e da ordem, como informa o art.142, da Constituição da República Federativa do Brasil. Visto por esta ótica, a modernização dos meios terrestres não pode ser priorizada sobre a manutenção dos meios de defesa nacional.

Diante deste quadro, de limitados recursos e dependente de hierarquização, pensamento político em vigor, é que se depara com consequente deficiência de alguns sistemas de esgoto, que são mantidos sob muito esforço, sendo que muitos deles foram executados em datas distantes, cuja idade avançada contribui para a necessidade de sua reforma ou até mesmo construção de nova rede.

Como citado no capítulo 2, um percentual razoável do país não possui uma rede de esgoto pública. O reflexo disso é que o sistema de coleta e tratamento dos efluentes nos alojamentos e, em quase todos os quartéis, é feito por um sistema particular de tratamento, as fossas, complementadas por filtros, dentre alguns poucos sistemas de Estações de Tratamento de Esgotos mais modernos.

A seleção do sistema de fossas decorreu da sua economia e razoável eficiência, pois possui baixo custo de execução, facilidade de manutenção, não agrega carga energética a ser consumida, dispensa mão de obra de alta especialização e atende a demanda usual dos quartéis, especialmente as das Organizações Militares situadas em lugares de difícil acesso. Isso não significa que a sua eficiência seja atingida, mas é satisfatória no momento em que seus $60 \%$ de eficiência são melhores do que um simples sumidouro, situação que poderia ser a existente se não fossem as fossas sépticas.

Estas Organizações Militares podem ser consideradas por analogia como pequenos condomínios isolados, o que indica a escolha das fossas sépticas segundo DE ARAUJO e NUVOLARI (2012, p. 256), que assim discorre: 
Para atender sistemas individuais, tais como residências ou condomínios isolados, há a opção de se utilizar fossas sépticas FS, também chamadas de decantodigestores. O efluente das FS poderá ser lançado em sumidouros (SU), valas de infiltração (VI) ou por filtros anaeróbios de fluxo ascendente (FAFA), antes da disposição final, que poderá ser feita também em rios ou córregos.

O sistema particular de tratamento por meio das fossas sépticas está regularmente previsto nas normas brasileiras. Segundo a NBR 8160 (ABNT, 1999):

4.1.4 A disposição final do efluente do coletor predial de um sistema de esgoto sanitário deve ser feita:

a) em rede pública de coleta de esgoto sanitário, quando ela existir;

b) em sistema particular de tratamento, quando não houver rede pública de coleta de esgoto sanitário.

Como dito, a modernização do sistema se faz necessária, mas a realidade atual na Marinha do Brasil é a existência do sistema fossa-filtro anaeróbio, que encontra-se dependente de novas licitações.

\subsection{2}

\section{Fossas Sépticas}

Embora não seja a melhor solução, ou seja, a mais eficiente, as fossas sépticas foram adotadas pela Marinha do Brasil há décadas, seja por ser o conceito de engenharia adotado à época, seja por não ter sido priorizada uma modernização nos sistemas existentes de esgoto. Como solução ao longo dos anos foram incluídos no sistema os filtros anaeróbios de fluxo ascendente (FAFA) com a finalidade de melhorar a qualidade dos efluentes.

De acordo com o tempo, para a melhoria de sua eficiência, foram acoplados filtros anaeróbios para que houvesse uma melhora do sistema, mas, ainda sim, o sistema ideal é a entrega do material coletado para a rede pública ou adotar sistemas com maior grau de eficiência como as UASB, ETE, dentre outros modelos mais modernos de tratamento.

Os quartéis da Marinha do Brasil, em quase toda a sua totalidade, aproximadamente $70 \%$, enviam suas águas residuais para uma fossa séptica, o que requer uma análise desta forma de tratamento do esgoto e das interferências a que ela pode ser submetida. 
De acordo com MACINTYRE (2012, p. 155) as fossas sépticas são:

Unidades de tratamento primário de esgotos domésticos que detém os despejos por um período que permita a decantação dos sólidos e a retenção do material graxo, transformando-os em compostos estáveis. Constam essencialmente de uma câmara ou unidade de decantação, ou sedimentação, e uma de digestão, na qual o líquido cloacal passa pelo fenômeno bioquímico de digestão...

De acordo com DE ARAUJO e NUVOLARI (2012, p. 256), tem-se que:

As fossas sépticas ou decanto-digestores consistem geralmente de uma câmara, cuja função é permitir a sedimentação, o armazenamento dos sólidos sedimentáveis (lodo) e a sua digestão, que ocorre em ambiente anaeróbio. Dessa decomposição é gerado o gás natural $\left(\mathrm{CH}_{4}+\mathrm{CO}_{2}\right)$, além de pequenas quantidades de gás sulfídrico $\left(\mathrm{H}_{2} \mathrm{~S}\right)$, mercaptanas, escatóis, etc.

Em alguns casos, a ausência de uma rede coletora pública de esgoto sanitário impede que a Marinha do Brasil efetue uma ligação a um tronco coletor, situação essa a mais desejável, por não ser a Marinha do Brasil especializada em tratamentos de esgotos. Por consequência, surge a necessidade de adoção de um tratamento adequado dos efluentes no próprio quartel, a fim de que se possa despejar estes líquidos para o meio ambiente com razoável grau de aceitação.

As fossas sépticas foram adotadas como solução nos quartéis há muitos anos, e, como já citado, muitos deles aguardam recursos orçamentários para a sua ampliação e adequação do sistema de esgoto. Esta solução tem sido considerada tanto nas reformas quanto nas construções novas, sendo que em algumas localidades utilizam o filtro após a fossa como complemento do tratamento, o que agrega um valor ao sistema no que concerne à proteção do meio ambiente.

De fato, o sistema merece uma modernização, seja por meio de integração às redes públicas, seja por meio de adoção de novos sistemas de tratamento como as ETE e UASB. Existem no mercado estações compactas de tratamento que são de adoção simples e mais barata. Estas estações unem na mesma câmara (ou no mesmo conjunto) o tanque de aeração e o de decantação final, seguido ou não de outro tanque de aeração, de digestão aeróbia, conforme a necessidade a ser atendida para a melhor qualidade dos elementos residuais. Estas estações compactas atendem até uma população de 50 mil pessoas, o que se adequa perfeitamente aos quartéis, o que será melhor explicitado no item 4.3.6 procedimentos sugeridos. 
Veja-se uma Estação Compacta conforme indicado na figura 4.3:

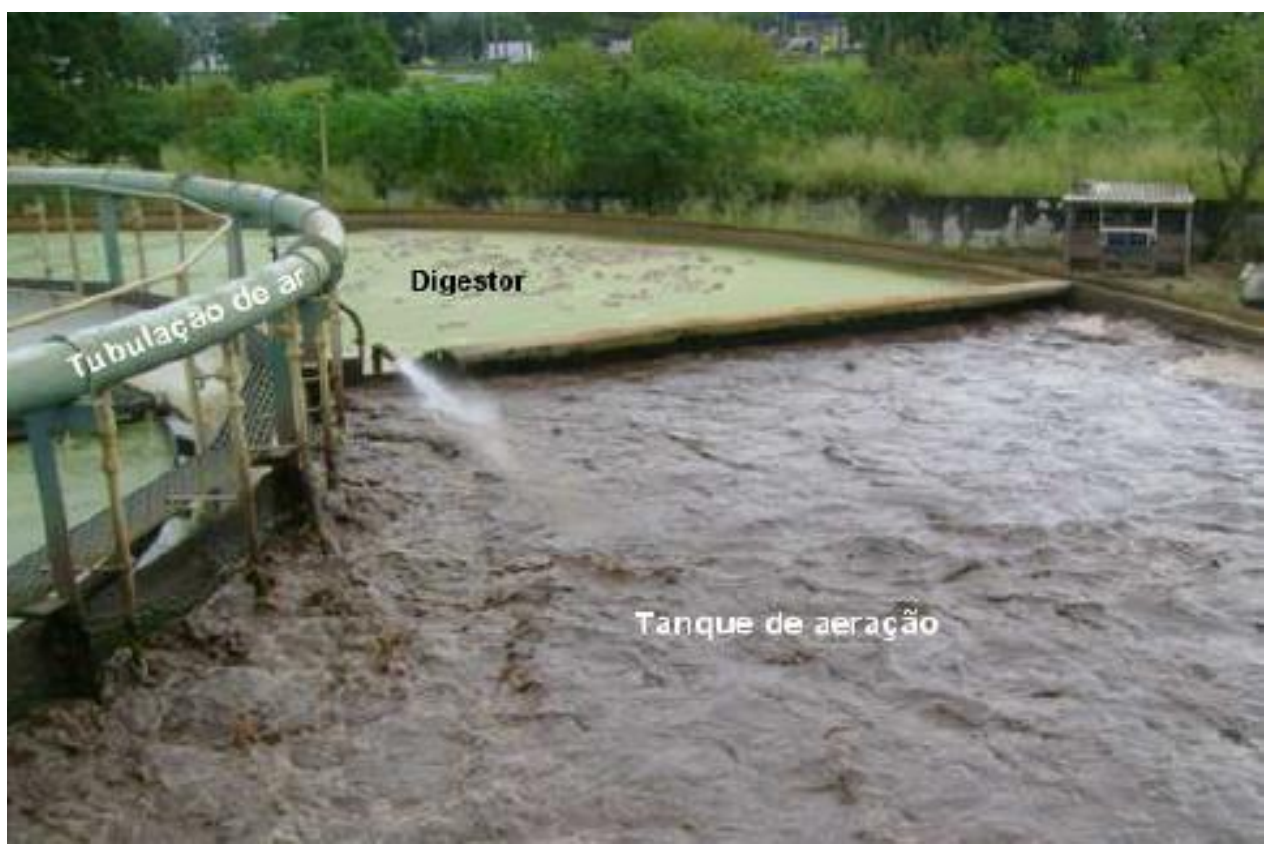

Figura 4.3: Vista superior da Estação Compacta de Deodoro. Fonte: http://monografias.poli.ufrj.br/monografias/monopoli10001831.pdf.

As fossas sépticas são câmaras que têm o fim de reter os despejos do esgoto, por um determinado período, que seja suficiente para a ocorrência do processo bioquímico desejado, permitindo a liberação de um novo produto, que é uma transformação em substâncias e compostos mais simples e estáveis, que melhorar e minimizam o impacto quando lançados de volta ao meio ambiente.

A fossa séptica, pois, objetiva reduzir a carga de contaminação dos materiais despejados, que serão posteriormente reinseridos no meio ambiente. Fala-se em redução porque nunca o líquido será devolvido à natureza no mesmo estado em que foi entregue: água pura e limpa para consumo, salvo se houver um tratamento mais específico (e certamente mais oneroso) para o seu reuso, o que requer tecnologia e mais recurso financeiro.

MACINTYRE (2012, p. 156) chama a atenção para lembrar que a fossa séptica não é uma estação de tratamento completa. E informa que a fossa não possui grades, caixas de areia, bem como qualquer outra retenção de materiais que não sofram a ação bioquímica, ou seja, não possui um tratamento primário. Dessa forma, nas fossas sépticas não é possível se lançar materiais de cozinha, lavagem que tenha mistura com óleos no descarte e outros produtos que impeçam ou 
retardem as reações químicas que devem acontecer no interior da fossa. A solução é lançar os materiais de lavagem para uma caixa de inspeção e dali para um sumidouro, ou aplicar um outro tratamento.

No caso dos resíduos de tanques de lavar roupa, informa MACINTYRE (2014, p. 156) que se efetuando um bom dimensionamento é possível o lançamento nas fossas. Entretanto, esta ação não é adotada nos quartéis da Marinha do Brasil.

No caso dos resíduos da cozinha, deve-se encaminhá-los para uma caixa de gordura e executar uma manutenção permanente com a limpeza e retirada dos materiais ali acumulados, descartando-os em lugar adequado, sem impactar o meio ambiente.

A fossa é uma escolha que acarreta alguns incômodos naturais como o odor e a necessidade de manutenção regular. Ainda que seja bem dimensionada, ainda assim é possível que haja o escape do gás sulfídrico e outros, que se alastram a sua volta provocando um odor característico. Dessa forma, sugere-se um estudo antecipado de sua localização na Organização Militar, podendo situarse próxima a um pátio de reciclagem que, por si só, emana odores dos materiais que ali são estocados por um período.

No interior da fossa séptica flota na sua parte superior uma espuma cuja denominação é escuma, constituída de gorduras e substâncias graxas, misturada com gases oriundos da decomposição anaeróbia que ocorre no interior de sua câmara. Por esta razão, cita DE ARAUJO e NUVOLARI (2012, p. 256), a fossa séptica deve possuir defletores ou ser executada um nível abaixo da superfície, o que evita que a escuma saia juntamente com o efluente.

Uma das razões para se executar da caixa de gordura na saída das tubulações da cozinha é justamente para evitar o acúmulo da escuma, que aumenta com a gordura que porventura seja para ali enviada.

A limpeza da fossa deve obedecer uma periodicidade de forma rigorosa. Quando for prevista a sua limpeza por um caminhão limpa-fossa é recomendável que no projeto já se inclua uma tubulação vertical, a fim de facilitar o serviço. DE ARAUJO e NUVOLARI (2012, p. 256) recomenda que esta tubulação tenha, no mínimo, 15 centímetros, situando-se a 20 centímetros do fundo.

Quanto a qualidade do descarte, diversas pesquisas foram efetuadas sobre a carga orgânica residual após a passagem dos efluentes nas fossas sépticas. 
Segundo DE ARAUJO e NUVOLARI (2012, p. 258), referindo-se a dados obtidos por Azevedo Netto e Lothar Hess (apud Batalha, 1986), foram observadas as eficiências abaixo de remoção nos efluentes de fossa séptica bem projetadas e bem construídas:

DBO (demanda biquímica de oxigênio): 40 a $60 \%$ de remoção DQO (demanda bioquímica de oxigênio): 30 a $60 \%$ de remoção SS (sólidos sedimentáveis): 50 a $70 \%$ de remoção

OG (óleos e graxas): 70 a 90\% de remoção

E, ainda, cita o autor que pesquisa feita por Vieira e Sobrinho (1983), mostram os seguintes dados para as fossas sépticas de câmara dupla:

DBO (demanda biquímica de oxigênio): $62 \%$ de remoção

DQO (demanda bioquímica de oxigênio): $57 \%$ de remoção

SS (sólidos sedimentáveis): $56 \%$ de remoção

CT (coliformes fecais): $55 \%$ de remoção

Segundo JORDÃO e PESSOA (1971, p. 163), a fossa séptica não "purifica" os esgotos, apenas reduz a sua carga orgânica a um grau de tratamento aceitável. E conclui que é necessária uma atenção maior à disposição dos efluentes das fossas sépticas, o que indica a sua baixa eficiência, que é comumente indicada pelos parâmetros de sólidos em suspensão e DBO, sendo que reduz em média $60 \%$ dos sólidos em suspensão e de 49 a 60\% para vazões médias de 1000 litros/dia, conforme informa JORDÃO e PESSOA (1971, p. 169).

Segundo BRITTO (2004, p. 110-111), a hidrólise é a responsável maior pela eficiência do tratamento nas fossas sépticas, e decorre dos microorganismos produtores de ácidos. Assim, grande parte das bactérias aeróbias são arrastadas para o próximo tratamento aonde haverá a metabolização dos compostos solúveis das bactérias aeróbias restantes.

É importante observar que um dos fatores que delimitam a adoção das fossas sépticas é a taxa de infiltração do esgoto no solo, que representa a permeabilidade do solo, além da disponibilidade do espaço, pois requer um espaço para a escavação e área de superfície livre para a sua manutenção; a inclinação do terreno, que permite o carreamento por gravidade dos efluentes; a profundidade de um possível lençol freático, que pode ser contaminado pelo esgoto; estar distante de águas superficiais e de poços, também para evitar a 
contaminação destes; estudar o uso da água a juzante nos corpos receptores. Todos estes cuidados devem ser observados quando da concepção do projeto.

Nas fossas sépticas o tratamento tem duas formas bem evidenciadas de tratamento, sendo uma física, cuja finalidade é reduzir os sólidos presentes, baseado na diferença de densidade; a outra biológica, que ocorre pela oxidação que causa a redução da demanda bioquímica de oxigênio (DBO).

A redução da carga de contaminação e impacto no meio ambiente é feita por meio de um processo bioquímico que possui várias fases e se apresenta, ao fim com 4 partes visíveis básicas: lodo no fundo; escuma ou crosta na superfície; água e gases.

Conforme citado por MACINTYRE (2012, p. 155), inicialmente os microorganismos, que no esgoto são tanto aeróbios quanto anaeróbios, fazem a primeira reação ao retirar o ar tanto do oxigênio quanto das substâncias orgânicas. Este processo causa uma ação de oxidação.

Durante a oxidação, ou seja, enquanto os microorganismos reagem com o oxigênio, o nitrogênio, que se encontra também na massa de esgoto fresca (orgânicos, proteínas, ureia), reage com o hidrogênio que sobra da molécula de ar e forma a amônia e compostos amoniais.

Os compostos amoniais dão origem aos ácidos nitroso e nítrico. Estes ácidos reagem com os sais dissolvidos ou em suspensão e formam os nitritos e sais minerais. Agora temos matérias que são imputrescíveis e inócuos (é a denominada nitrificação).

A primeira parte definitiva decorrente das reações é esta matéria decorrente da nitrificação, que tem a aparência de um lodo ou lama e se deposita no fundo da fossa.

Este fenômeno também ocorre com o carbono, enxofre e fósforo. Destes surgem os carbonatos, sulfetos, sulfatos e fosfatos.

Além desta massa que vai para o fundo, também surgem os materiais graxos leves, que se depositam na superfície, sendo mais insolúveis.

A segunda parte definitiva decorrente das reações, pois, são estes graxos leves que flutuam e formam uma camada de escuma ou crosta na superfície. A definição técnica de escuma se encontra no item 3.11, da NBR 7229 (ABNT, 1993), ou seja, matéria graxa e sólidos em mistura com gases, que flutuam no líquido em tratamento. 
A terceira parte definitiva das reações é a água. Os ácidos graxo liberam hidrogênio e, se ainda existir alguma ação de microorganismos, ocorre a reação deste hidrogênio com o oxigênio liberado da oxidação, o que forma água.

A quarta parte definitiva das reações são os gases. Os principais a serem citados são o metano $\left(\mathrm{CH}^{4}\right)$ a gás carbônico $\left(\mathrm{CO}^{2}\right)$. Lembrando-se que o metano tem alto potencial energético e pode ser utilizado de forma sustentável, mas também tem forte odor, o que gera o incômodo de se colocar fossa séptica próxima a locais aonde ficarão pessoas por tempo prolongado.

Em aferição visual do processo, segundo MACINTYRE $(2012$, 155), o que se verifica é: a retenção do esgoto (varia entre 12 a 24 horas, dependendo dos materiais recebidos), a decantação do esgoto (sedimentação parcial dos sólidos suspensos, que forma o lodo. $\mathrm{O}$ resto se torna a crosta/escuma); digestão aeróbia do lodo e escuma (aqui destroem-se parte dos organismos patogênicos); redução do lodo (com surgimento de gases e água).

Como citado também por MACINTYRE (2014, p. 156):

A finalidade da fossa é proporcionar condições favoráveis à ação rápida das bactérias aeróbias e principalmente das anaeróbias, e uma fossa será tanto mais perfeita e eficaz quanto mais depressa e integralmente realizar a transformação da matéria cloacal do afluente em sedimentos ou lamas imputrescíveis e inócuas, permitindo, assim, que o efluente possa, sem riscos de contaminação e o inconveniente do mau odor, ser lançado num sumidouro, numa vala de infiltração, ou filtração, ou, ainda, num curso d'água.

No que se relaciona com a sedimentação, que é o processo em que, por gravidade, sólidos em suspensão se separam do líquido que os continha, conforme o item 3.26, da NBR 7229 (ABNT, 1993), MACINTYRE $(2014,156)$ informa que numa instalação de fossa séptica bem projetada e construída pode-se seguir os resultados indicados na tabela 4.1, para fins de controle da eficiência da fossa:

Tabela 4.1: Eficiência das fossas sépticas. Fonte: NBR 7229 (ABNT, 1993).

\begin{tabular}{|c|c|}
\hline Remoção de sólidos em suspensão & 50 a $70 \%$ \\
\hline Redução de bacilos coliformes & 40 a $60 \%$ \\
\hline Redução de DBO & 30 a $60 \%$ \\
\hline Remoção de graxas e gorduras & 70 a $90 \%$ \\
\hline
\end{tabular}


Como se pode observar, os resultados são bem semelhantes ao DE ARAUJO e NUVOLARI (2012, p. 258). Ainda, segundo JORDÃO e PESSOA (1971, p. 165), tem-se a eficiência conforme a tabela 4.2:

Tabela 4.2: Eficiência das fossas sépticas.

Remoção de sólidos em suspensão

$60 \%$

Redução de DBO

35 a $61 \%(2000$

l/dia)

49 a $60 \%(1000$

l/dia)

$84 \%$

(adição lodo)

Segundo a NBR 7229 (ABNT, 1993), os sistemas de tanques sépticos,

incluindo tratamento e disposição de efluentes e lodo sedimentado, têm por objetivo preservar a saúde pública e ambiental, a higiene, o conforto e a segurança dos habitantes de áreas servidas por estes sistemas. Logo, a importância da proteção ambiental e do homem é um requisito essencial ao regular funcionamento do sistema.

Aliás, da mesma forma que o sistema predial de esgoto, é vedado o encaminhamento ao tanque séptico de águas pluviais e despejos que interfiram no processo de tratamento ou elevação da vazão do esgoto afluente, conforme prescrito no item 4.3.2, da NBR 7229 (ABNT, 1993).

Ao se projetar um tanque séptico é necessário que se verifique se os efluentes que ali serão tratados estão em conformidade com os índices mínimos que permitam que o mesmo seja eficiente, não se esquecendo de que o sistema deve ser projetado de forma completa, ou seja, não se deve limitar o projeto à verificação da fossa em si, mas abranger a disposição final para o efluente e o próprio lodo, seu resíduo, como determina o item 4.4.1, da NBR 7229 (ABNT, 1993). E a eficiência do sistema é a garantia de parâmetros, sendo que alguns estão dispostos na própria norma técnica. MACINTYRE $(2014,157)$ lisa algumas recomendações: 
- verificação das condições do terreno - dimensões e permeabilidade

- instalações de grande porte - recomenda efetuar a desinfecção com cloro das fossas, pois há uma redução das bactérias de 98 a 99\%.

As fossas sépticas também são projetadas de acordo com a vazão a ser tratada. A fórmula adotada para o cálculo de seu volume útil total é efetuado segundo a seguinte equação 4.1, indicada pela norma técnica:

$\mathrm{V}=1000+\mathrm{N}\left(\mathrm{C} \times \mathrm{T}+\mathrm{K} \times \mathrm{L}_{\mathrm{f}}\right)$,

onde:

$\mathrm{V}=$ volume útil (litros)

$\mathrm{N}=$ número de pessoas ou unidades de contribuição

$\mathrm{C}=$ contribuição de despejos (litros/pessoa x dia ou litros/unidade x dia)

$\mathrm{T}=$ período de detenção (dias)

$\mathrm{K}$ = taxa de acumulação de lodo digerido em dias $(\mathrm{k})$ -

equivalente ao tempo de acumulação de lodo fresco

$\mathrm{L}_{\mathrm{f}}=$ contribuição de lodo fresco (litros/pessoa $\mathrm{x}$ dia ou litros/

unidade $\mathrm{x}$ dia)

A contribuição da fossa séptica deve ser calculada segundo o número de pessoas atendidas (diferenciando-se se o prédio formisto entre ocupantes permanentes e temporários), e considerando-se $80 \%$ do consumo de água.

Quando não for possível estabelecer o consumo de água, indica-se a utilização dos parâmetros de projeto constantes na tabela 1, da NBR 7229 (ABNT, 1993).

Deve-se considerar um período mínimo de retenção dos despejos. Isto porque deve-se efetuar os cálculos considerando o tempo mínimo para a ocorrência das reações químicas desejadas. Este tempo também já se encontra na tabela 2, da NBR 7229 (ABNT, 1993). Segundo BRITTO (2004, pg. 110):

Uma fossa séptica, para um perfeito funcionamento, leva cerca de 5 meses, pois há a necessidade de se cumprir várias fases da digestão anaeróbia.... a digestão não é um processo estático, ocorrendo as três fases ao mesmo tempo (lodo cru, regressão ácida e fermentação alcalina). As duas primeiras fases constituem o período de maturação da fossa, que demanda aproximadamente 5 meses. É de todo o interesse que a fase dominante seja a fermentação alcalina, sendo necessário para tanto que, ao se limpar fossas, deixar sempre uma determinada quantidade de lodo digerido, rico em enzimas e microorganismos ativos que irão 
assegurar a digestão rápida e eficiente do lodo cru que se depositarão a zona de sedimentação da fossa.

Outro importante parâmetro é a taxa de acumulação do lodo, que ficará no fundo do tanque e deverá ser removido de acordo com um período a ser considerado nos cálculos. Portanto, a adoção desta taxa irá influenciar diretamente no dimensionamento da fossa séptica. Esta taxa de acumulação total do lodo (denominada k) também está prevista na tabela 3, da NBR 7229 (ABNT, 1993), mas, para a sua obtenção $(\mathrm{k})$, deve-se conhecer a faixa de temperatura ambiente e os intervalos de limpeza. Com estes dados, calcula-se o volume total do tanque e, em seguida, o projeto parte para a definição da geometria do tanque que pode tanto cilíndrico quanto prismático. Algumas limitações para as suas dimensões foram impostas por norma, a fim de que seja garantida a sua eficiência. Assim, a profundidade útil deve obedecer a valores mínimos e máximos, em função do volume útil, conforme a tabela 4, da NBR 7229 (ABNT, 1993).

Para os tanques cilíndricos o diâmetro interno mínimo é de 1, 10 metros. Para os tanques prismáticos largura interna mínima é de 0,80 metros, sendo que também deve obedecer a relação de comprimento/largura de 2:1, no mínimo e 4:1, no máximo.

A fossa séptica é composta de câmaras, com o fim de permitir as reações bioquímicas e facilitar a limpeza. A norma, em seu item 5.10, recomenda o uso de câmaras múltiplas para as fossas com o uso de até 30 pessoas (considerada de pequena a média). Além disso, no item 5.10.1, recomenda que haja uma proporção de 2:1 em volume, da entrada para a saída, para qualquer tipo geométrico de câmara. Existem ainda medidas para aberturas para a intercomunicação entre as câmaras, dispositivos para a entrada e saída e aberturas de inspeção, tudo conforme anexo A, da norma 7229 (ABNT, 1993).

Veja-se nas figuras 4.4 e 4.5 dois esquemas exemplificativos de fossa séptica: 


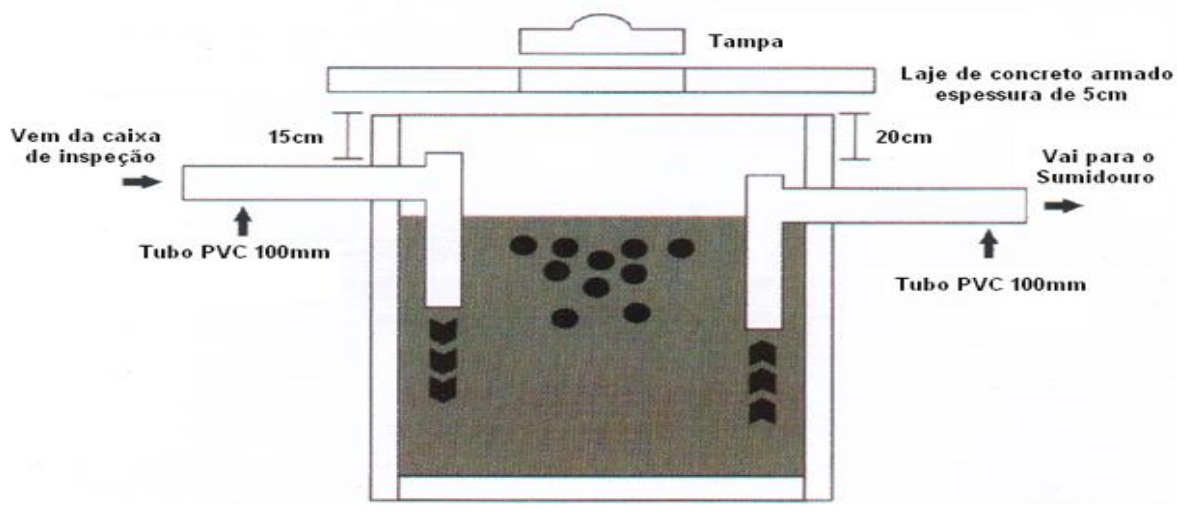

Figura 4.4: Esquema de uma fossa séptica retangular.

FOSSA SEPTICA
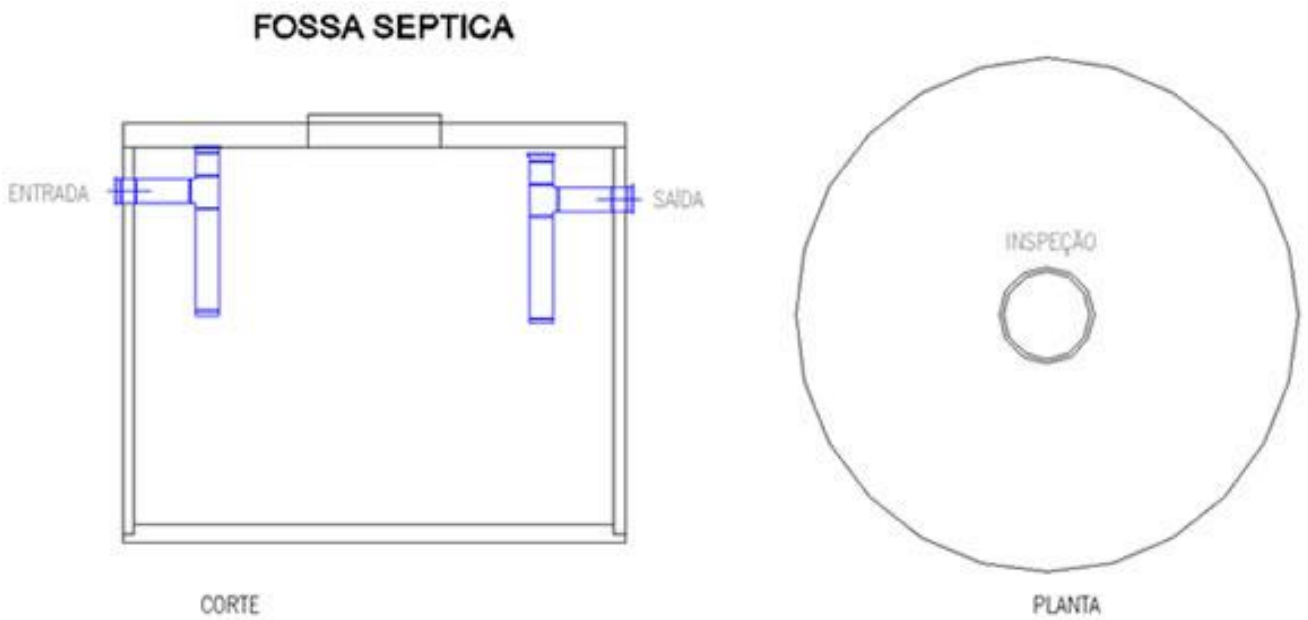

Figura 4.5: Esquema de uma fossa séptica circular.

A manutenção da fossa séptica é de grande importância para a eficiência do sistema de tratamento e, apesar de sua manutenção ser simples, requer cuidados regulares.

Aliás, o intervalo de limpeza é um fator que é considerado nos cálculos. Por isso mesmo, deve ser observado de forma rigorosa a fim de não alterar os tempos das reações bioquímicas e nem extravasar por excesso de escuma ou lodo.

É importante que o projetista deixe um plano de limpeza como procedimento necessário para a garantia da eficiência do sistema. Nos lugares aonde o sistema seja antigo, de pequeno a médio porte, e desconheça-se o intervalo adotado para o seu cálculo, ao menos uma vez por ano deve ocorrer a limpeza, com a retirada de todo o lodo existente. É claro que em casos de grandes contribuintes este número irá aumentar.

Nos casos dos quartéis localizados em grandes centros urbanos é comum a celebração de um contrato de empresa que execute este tipo de serviço com o uso 
de caminhão limpa-fossa, figura 4.6, o que se dá por meio de uma licitação. As empresas modernas atuam com veículos equipados com sistemas de alto vácuo que transportam, inclusive, materiais pastosos e granulados, o que aumenta a eficiência da limpeza e a rapidez do procedimento, além de eliminar a contaminação das pessoas que manuseiam os equipamentos de limpeza.

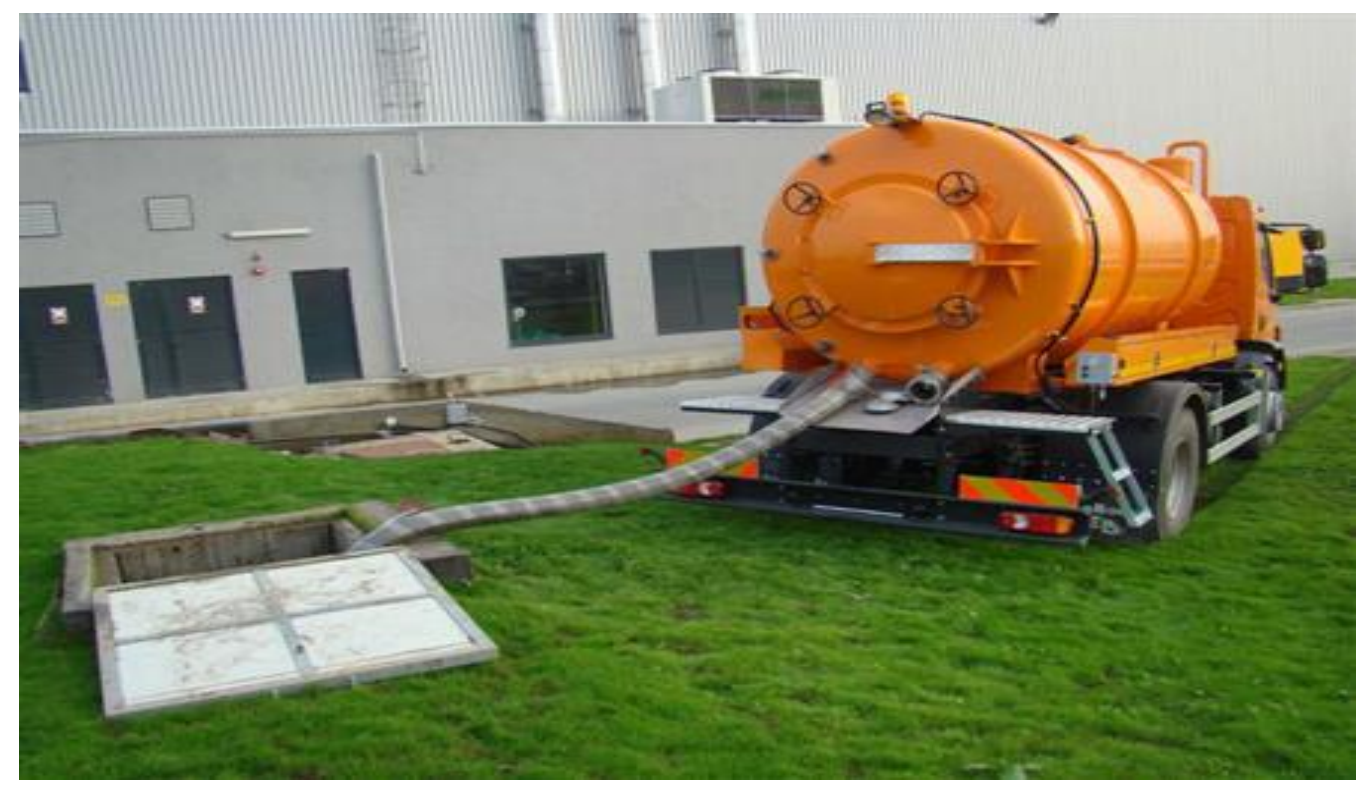

Figura 4.6: Caminhão limpa-fossa. Fonte: http://liderdesentupidoracuritiba.com.br/.

Os lodos e as escumas que são retirados das fossas não podem, por motivos óbvios, serem lançados em corpos d’água ou galerias de águas pluviais e, quando for extremamente necessário ao projeto, o pedido de despejo deverá ser analisado pelos órgãos ambientais, que analisarão a conveniência e possibilidade da execução deste tipo de destinação dos resíduos. Por isso, a necessidade de um tratamento complementar como ocorre com os filtros.

Em casos em que os quartéis estejam em lugares ermos e não exista estações de tratamento ou algum lugar indicado pelo órgão ambiental, o lodo deverá ser colocado em um leito de secagem. Mas deve-se atentar para a sua localização, especialmente em relação a sua cota, pois deve ser mais alta que a cota de alagamento prevista, pois não se pode permitir que o lodo venha a ser arrastado e misturado com as águas da chuva, a fim de eliminar qualquer possibilidade de contaminação do solo e, por fim, do meio ambiente, garantindo, inclusive, a saúde das pessoas e integridade da fauna de da flora do entorno. Esta previsão está disposta no item 6.2.2.3, da NBR 7229 (ABNT, 1993). 


\subsection{3}

\section{Filtro Anaeróbio}

As fossas sépticas são uma opção de baixo custo e de fácil manutenção. Mas não se pode dizer que são uma forma de tratamento definitiva e perfeita. Por isso, adotam-se tratamentos complementares para a melhoria da qualidade dos resíduos, em verdade para a melhoria de qualidade da carga orgânica.

No caso da Marinha do Brasil, tem-se como regra acoplar filtros anaeróbios de fluxo descendente (FAFA) na totalidade de sistemas com fossas nos quartéis. O FAFA consiste em um tanque dotado de uma laje inferior perfurada. Tendo seu acesso de entrada pela parte inferior abaixo da laje perfurada que sustenta o material de enchimento, como ele entra na parte inferior do filtro e atravessa o leito em um fluxo ascendente, o leito é afogado, ou seja, os vazios são preenchidos com efluente. Pela alta concentração de matéria orgânica por unidade de volume fazem com que as bactérias neste processo sejam anaeróbias, este leito de enchimento pode ser feito de material variado, desde que permita a formação de um filme biológico sob condições anaeróbias, responsável pela decomposição da matéria orgânica.

Segundo DE ARAUJO e NUVOLARI (2012, p. 258) o líquido efluente da fossa séptica ainda é altamente contaminado por coliformes fecais e dotado de uma DBO solúvel relativamente alta, e isso deve ser levado em conta na sua disposição final. Existem diversos tipos de tratamentos complementares, tais como o filtro biológico, sistemas de lodos ativados, reator anaeróbio de fluxo ascendente (ou reator UASB), dentre outros, sendo o filtro anaeróbio de fluxo ascendente uma solução de baixo custo e de excelente resultado.

A absorção do solo é um fator importante nas fossas sépticas, o que deve ser verificado por meio do levantamento do grau de permeabilidade do solo para fins sanitários. A NBR 7229 (ABNT, 1993) prevê na tabela 9.4, a profundidade útil em função do volume útil do tanque séptico, já determinando profundidades mínimas e máximas a serem observadas. Também na mesma norma são indicadas duas formas de levantar o parâmetro de permeabilidade do solo, que podem ser executados de forma simples.

Os sistemas que podem captar a destinação dos efluentes que advém das fossas séptica são: sumidouros, valas de infiltração, valas de filtração e os filtros 
anaeróbios de fluxo ascendente (FAFA), metodologia utilizada ordinariamente pela Marinha do Brasil por ser um destino que também acresce um tratamento complementar de maior eficiência.

Os sumidouros são indicados quando a taxa de absorção for igual ou superior a $401 / \mathrm{m}^{2}$.dia, conforme citado em DE ARAUJO e NUVOLARI (2012, p. 260), o que costuma ocorrer em solos com argilas arenosas ou siltosas. Nos sumidouros devem ser executados furos, ou seja, passagens para que haja a infiltração. O fundo deve estar livre para facilitar a percolação do líquido. Para facilitar a percolação com um elemento filtrante, nas laterais e no fundo é formado um leito de brita número 4. Na parte superior, deve existir um tampo para acesso, que deve ser em concreto armado, de acordo com a carga que por ali pode passar, com dimensão mínima de 60 centímetros, tudo conforme indicado na figura 4.7. Segundo DE ARAUJO e NUVOLARI, (2012, p. 260) apud BATALHA (1986), a distância mínima entre os sumidouros e um poço de água deve ser de 20 metros e o fundo deve estar acima do lençol freático, ao menos, 3 metros.
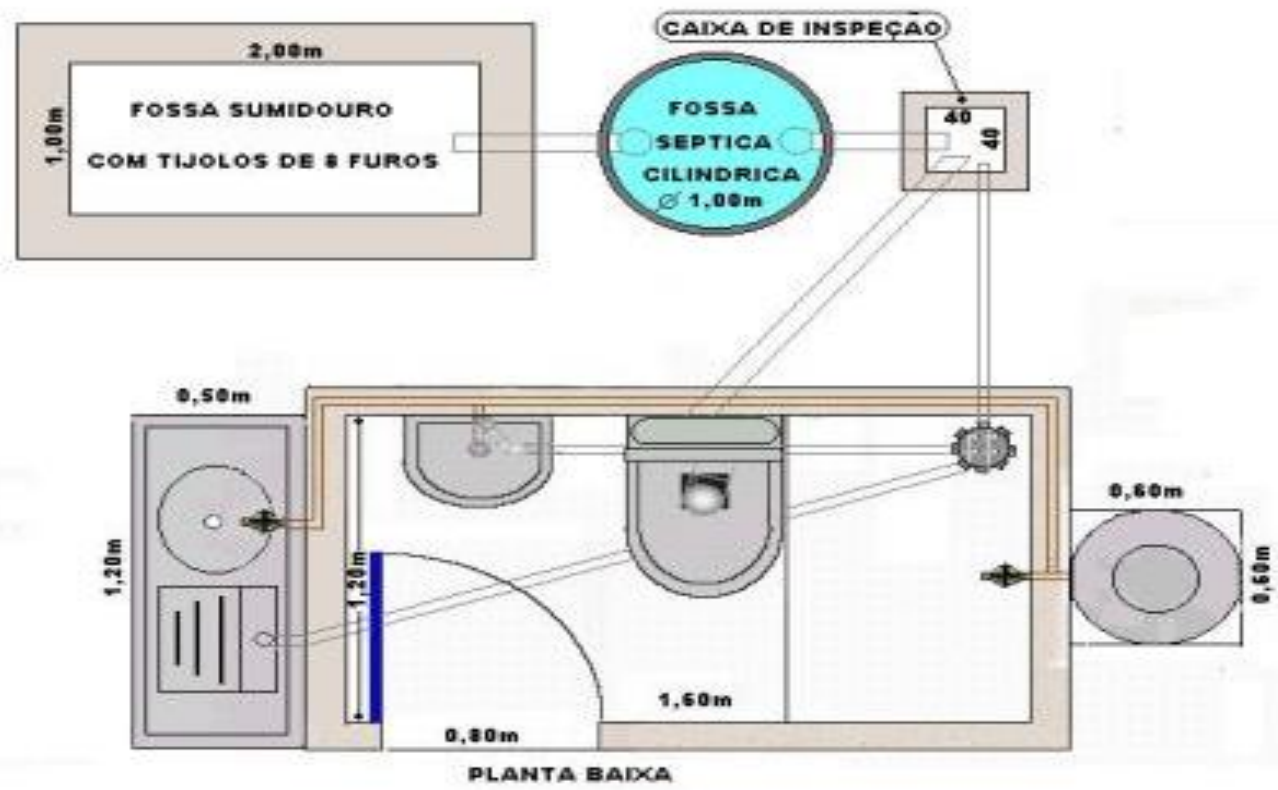

Figura 4.7: Esquema Fossa-Sumidouro.

As valas de infiltração podem ser utilizadas quando a taxa de absorção estiver entre $20 \mathrm{l} / \mathrm{m}^{2}$.dia e $40 \mathrm{l} / \mathrm{m}^{2}$.dia, conforme citado em DE ARAUJO e NUVOLARI (2012, p. 261), o que costuma ocorrer em solos argilosos medianamente compactos, variando para argilas pouco siltosas ou pouco arenosas. 
A NBR 7229 (ABNT, 1993) indica que sejam executadas, no mínimo, duas valas de infiltração, com o espaçamento mínimo entre elas de 1 metro e comprimento máximo da vala de 30 metros. O tubo deve ser perfurado na metade inferior com diâmetro mínimo de 100 mm, observando inclinações que podem variar de 0,2 a $0,33 \%$. Além de possuir uma camada de brita em seu redor, a norma indica que se faça uma cobertura da parte superior com papel alcatroado. Para que haja a distribuição uniforme entre as valas, é necessária a construção de uma caixa de distribuição. Segundo DE ARAUJO e NUVOLARI, (2012, p. 262) apud BATALHA (1986), pode-se estimar a extensão das valas de infiltração em 6 metros por pessoa (população que compõe o sistema de esgoto). Vide esquema na figura 4.8.
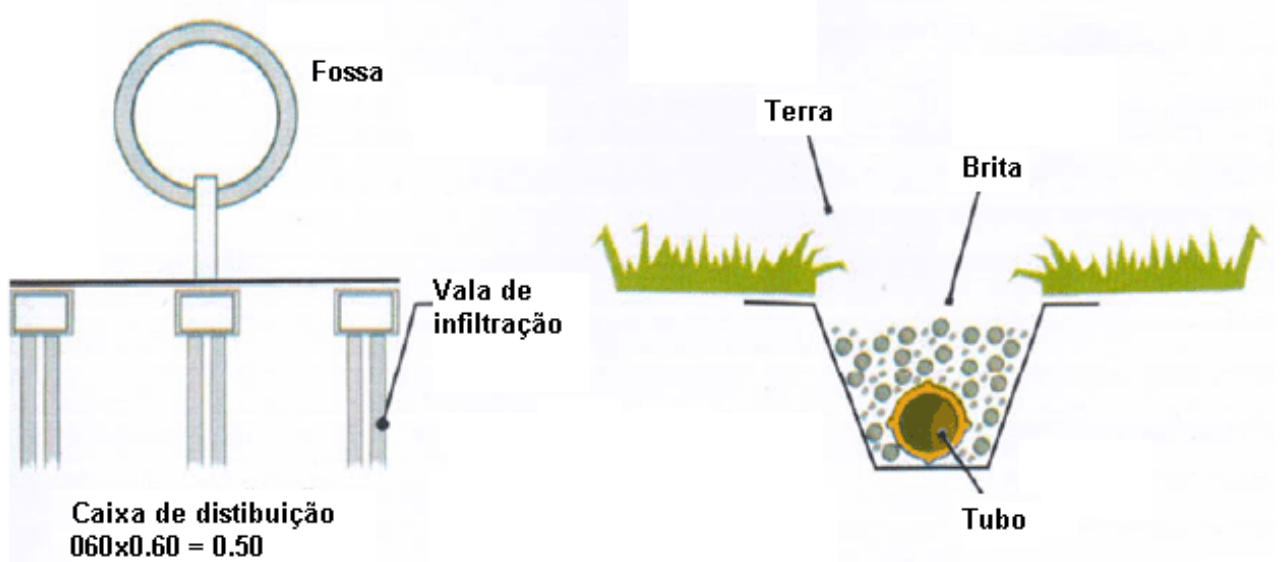

Figura 4.8: Esquema Fossa-Valas de infiltração.

As valas de filtração podem ser utilizadas quando a taxa de absorção estiver abaixo de $20 \mathrm{l} / \mathrm{m}^{2}$.dia, conforme citado em DE ARAUJO e NUVOLARI (2012, p. 261). É indicada quando o destino final do efluente for um corpo receptor (águas superficiais). O mesmo autor nos informa que o tipo de solo que usualmente apresenta esta taxa são argilas compactas branca, cinza ou preta, variando a rochas alteradas e argilas medianamente compactas de cor avermelhada e alguns tipos de rochas.

Este custo é o maior entre as opções anteriores, como informa DE ARAUJO e NUVOLARI (2012, p. 262), portanto, deve ser a última opção entre as outras acima. As valas de filtração são uma opção de tratamento do efluente da fossa séptica, pois funcionam de forma semelhante aos filtros biológicos. Possui 
uma camada de pedra com altura menor do que as dos filtros biológicos e uma camada de areia, que serve como um filtro mais lento.

O efluente da fossa séptica é similar ao efluente de um decantador primário, contendo sólidos dissolvidos ou finamente particulados. Este efluente, como citado por DE ARAUJO e NUVOLARI (2012, p. 262), passa pela camada de brita, que não se encontra saturada, logo contém ar. Quando ocorre esta passagem, forma-se um filme biológico, constituído de bactérias e diversos outros microorganismos. Este filme faz com que os sólidos do efluente fiquem ali aderidos, retidos, adsorvidos. Adsorção é a adesão de moléculas de um fluido (o adsorvido) a uma superfície sólida (o adsorvente). O grau de adsorção depende da temperatura, da pressão e da área da superfície - os sólidos porosos como o carvão ativado são ótimos adsorventes. As forças que atraem o adsorvato podem ser químicas ou físicas. A adsorção química também chamada quimissorção, é específica e é empregada na separação de misturas. Nela as moléculas (ou átomos) unem-se à superfície do adsorvente através da formação de ligações químicas (geralmente covalentes) e tendem a se acomodarem em sítios que propiciem o maior número de coordenação possível com o substrato. Uma molécula quimicamente adsorvida pode ser decomposta em virtude de forças de valência dos átomos da superfície e é a existência de fragmentos moleculares adsorvidos que responde, em parte, pelo efeito catalítico das superfícies sólidas.

Com a presença do oxigênio ocorre a degradação da matéria orgânica que ali ainda subsiste e a camada de areia grossa, que também possui um filtro natural biológico na sua superfície superior, fazendo uma filtração complementar de forma lenta.

É importante manter a camada de brita aerada, para permitir a renovação de ar e garantir a eficiência do sistema. A NBR 7229 (ABNT, 1983) informa que a remoção de DBO no sistema fossa-vala de filtração pode resultar em uma faixa de 80 a 98\%, o que é um excelente resultado. Ocorre que estas valas de filtração têm alto custo e são mais difíceis de serem executadas. Vide esquema na figura 4.9. 


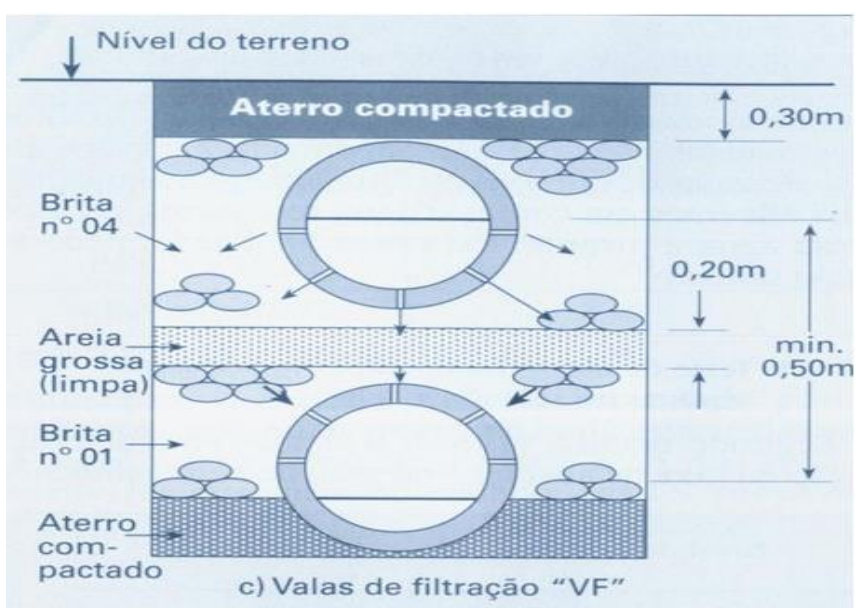

Figura 4.9: Esquema de valas de Filtração. Fonte: http://slideplayer.com.br/slide/366602/.

O filtro anaeróbio de fluxo ascendente (FAFA) é a alternativa adotada pela Marinha do Brasil como tratamento do efluente das fossas sépticas. Embora apresente eficiência menor do que as valas de filtração, que é de 75\% a 95\%, segundo a NBR 7229 (ABNT, 1993), tem um custo menor.

Este filtro é uma espécie de tanque que pode ser cilíndrico, quadrada ou retangular, possuindo um fundo perfurado por onde o efluente da fossa séptica entra e sobe por percolação pelos furos da laje que sustenta o material de enchimento, que é um elemento filtrante, normalmente brita $\mathrm{n}^{\circ} 4$.

Segundo DE ARAUJO e NUVOLARI (2012, p. 264), um material que pode substituir a brita $\mathrm{n}^{\circ} 4$ é o anel de Rashing plástico, pois tem uma eficiência maior em decorrência da alta relação área superficial/volume e baixo peso. O material de enchimento tem a função de criar um filtro biológico que é responsável pela degradação da matéria orgânica. A altura do material de enchimento deve ser de 1,20 metros e, segundo a NBR 7229 (ABNT, 1993), a altura total do filtro deve ser de 1,80 metros, para qualquer cálculo de filtro.

Segundo a norma, o método de dimensionamento deve ser conforme equação 4.2 que se segue:

$$
\begin{aligned}
& \mathrm{V}=1,60 \mathrm{~N} \times \mathrm{C} \times \mathrm{T}_{\mathrm{d}}, \\
& \text { sendo: } \\
& \mathrm{V}=\text { volume útil (litros) } \\
& \mathrm{N}=\text { número de contribuintes } \\
& \mathrm{C}=\text { contribuição unitária (litros/pessoa.dia) } \\
& \mathrm{T}_{\mathrm{d}}=\text { tempo de detenção (dias) }
\end{aligned}
$$


$\mathrm{A}=\mathrm{V} / 180$

$\mathrm{A}=$ área do filtro em planta $\left(\mathrm{m}^{2}\right)$

Resultado de levantamento de dados na Diretoria de Obras Civis da Marinha, aproximadamente $70 \%$ das Organizações Militares funcionam com o sistema fossa-filtro em diversos esquemas de fossa-filtro, como exemplificado nas figuras 4.10 e 4.11 a seguir.

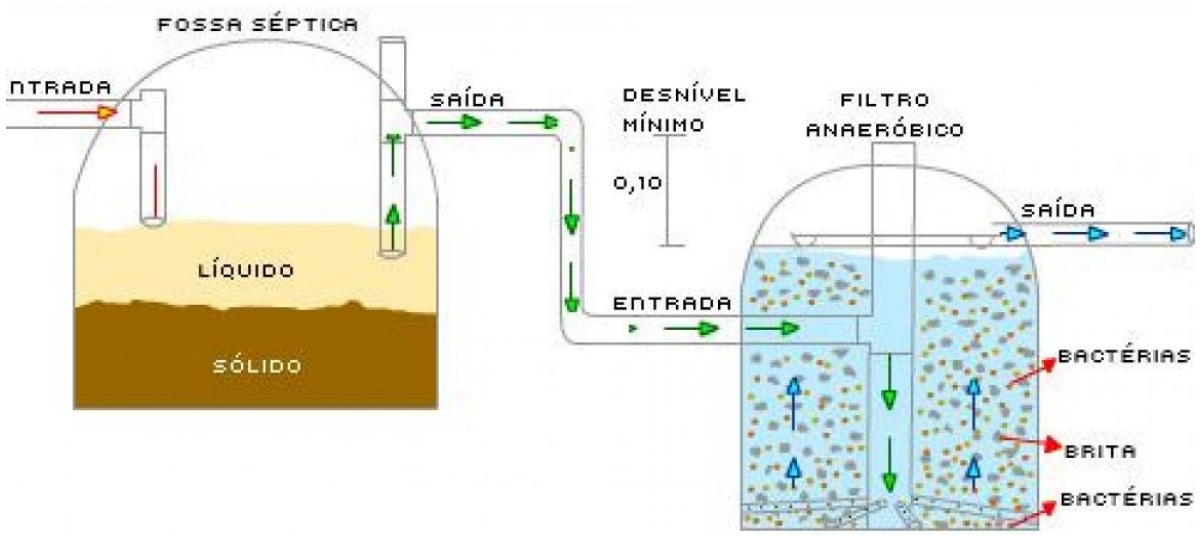

Figura 4.10: Sistema Fossa- Filtro-Corpo receptor. Fonte: a autora.

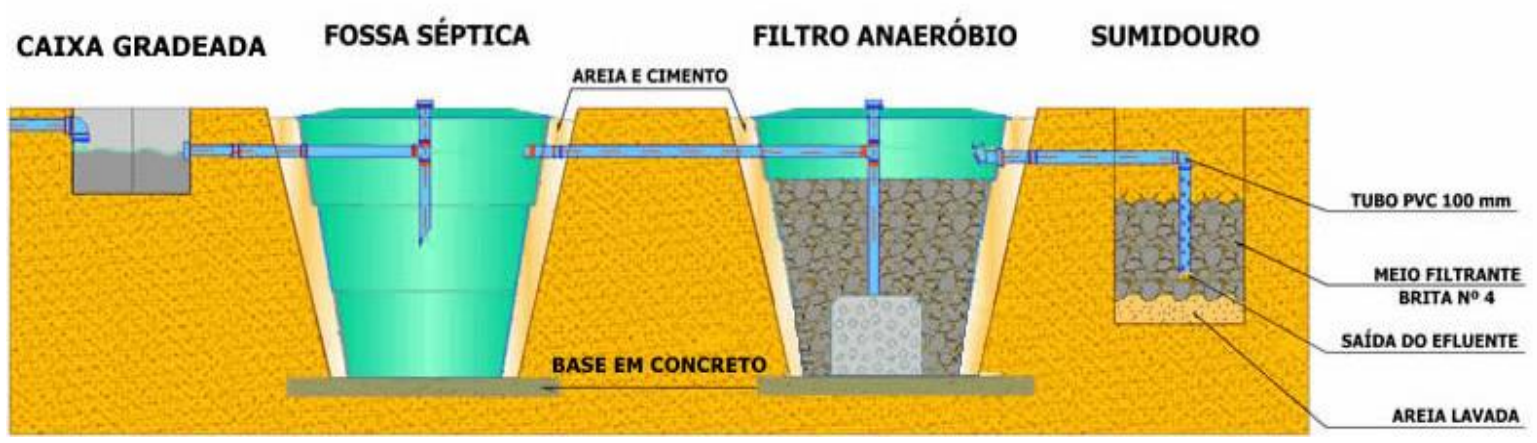

Figura 4.11: Sistema Fossa- Filtro-Sumidouro. Fonte: http://www.tecnosane.com.br/?product=fossa-septica.

Este sistema tem atendido a legislação de tratamento dos efluentes e assegurado um baixo consumo de energia, além de razoável ausência de odores e seu baixo custo de construção e manutenção e utilização de pequeno espaço para a sua construção. Este é um sistema ideal para os efluentes dos descartes das Organizações Militares nos casos aonde não há disponibilidade da rede pública. Uma segunda opção, que existe em poucas Organizações Militares em tem apresentado dificuldade de manutenção em decorrência do custo alto das 
contratações de terceirização, é a adoção de uma Estação de Tratamento de Esgotos (ETE), quando de grande quantidade o descarte, mas deve-se também considerar a existência de Estações Compactas de Tratamento de Esgotos, que atendem com maior eficiência que o sistema fossa-filtro, por ter um conjunto mais eficiente incluindo retentores de sólidos como caixas gradeadas o que é sugerido como uma metodologia de modernização para a Marinha do Brasil. Veja-se um exemplo de sua simplicidade construtiva conforme indicado na figura 4.12.

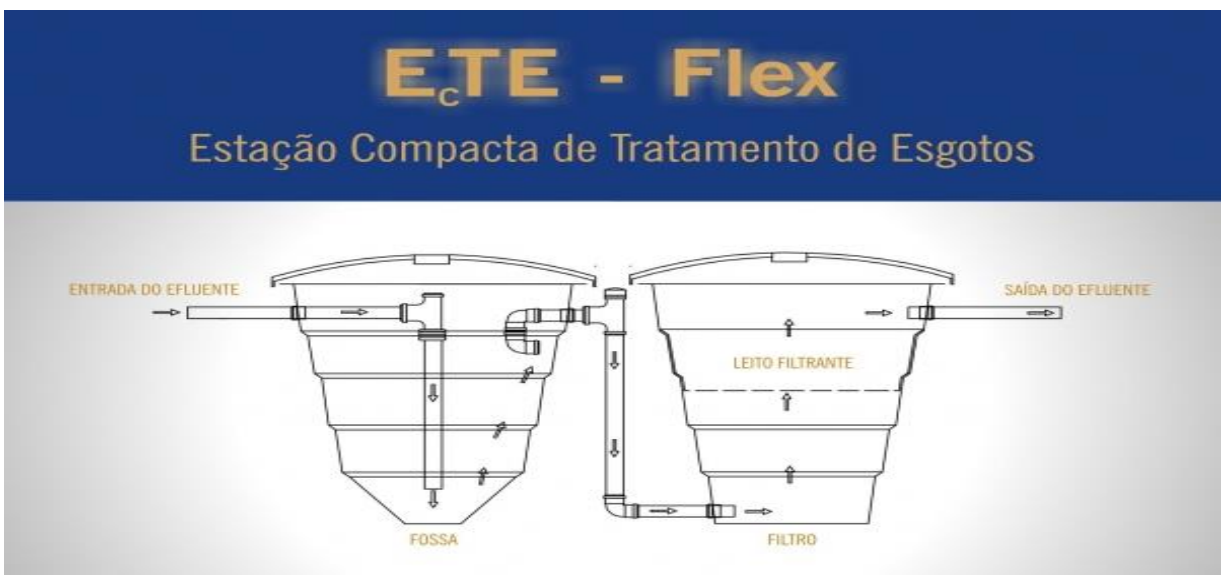

Estação Compacta de Tratamento de Esgotos

Figura 4.12: Estação compacta de Esgoto. Fonte: http://www.flexgrupo.com.br.

O desejável é que todo o sistema estivesse interligado às redes públicas. Entretanto, enquanto isso não é possível, a Marinha do Brasil tem efetuado a manutenção do sistema existente e conforme a disponibilidade financeira e das concessionárias, executado as interligações entre a rede da Marinha do Brasil e o tronco coletor colocado à disposição de forma superveniente à construção das Organizações Militares.

Por questões orçamentárias, a regra de projeto é a utilização do conjunto fossa-filtro, mas isso afeta a qualidade dos efluentes do sistema de esgoto, especialmente nas localidades mais interioranas ou privadas das redes públicas. Nas demais localidades, a manutenção do sistema requer um planejamento adequado, pois dependente de modernização em uma data não definida. Portanto, o sistema ideal para uma adequada e progressiva modernização é a instalação destas pequenas estações de tratamento, compactas e de custo acima do sistema fossa-filtro, mas com custo-benefício final melhor.

O tratamento através de uma fossa séptica retém os sedimentos e libera só a água para lançamento no solo. A sua manutenção, basicamente, é a sua limpeza, 
o que faz a grande diferença entre ela e a Estação de Tratamento de Esgoto, que possui uma complexa manutenção, e também de instalação bem mais cara. Entretanto, nos casos fluxos maiores de efluentes sugere-se as Estações Compactas, cujo benefício, no que concerne a sua eficiência, justifica o seu custo, que ainda é menor que os das ETE.

\subsection{4}

\section{Cotas Baixas dos Terrenos e Proteção do Sistema de Esgoto}

Outra questão relevante para e melhoria do desempenho do sistema e a sua consequente modernização é a situação usual da localização dos terrenos da Marinha do Brasil em cotas iguais ou abaixo do nível do mar. Usualmente estes terrenos se situam perto de rios ou mares, pois esta localidade é estratégica para facilitar a atuação e fiscalização da Marinha do Brasil, uma dentre suas diversas tarefas institucionais.

Desta forma, a garantia de estanqueidade do sistema de esgoto, de forma a impedir um retorno dos efluentes, quando da ocorrência de marés altas ou chuvas fortes, é um requisito imperativo para a eficiência do sistema, ou seja, para que se garanta o fluxo dos efluentes para a fossa séptica e desta para um filtro anaeróbio que se dirige para uma tubulação em executa o lançamento nos corpos receptores. Este lançamento direto para o meio ambiente observa a necessidade de ausência de qualquer grau poluente que possa contaminar pessoas e coisas, bem como garanta a ocorrência do processo bacteriológico em seu interior, antes do seu despejo, a fim de eliminar a possibilidade do lançamento ao meio ambiente com alto grau de concentração de orgânicos ou outro poluente nos rios e mares.

Com a localização do terreno em cota baixas há de se observar se há a possibilidade de retorno dos efluentes por refluxo para o sistema pela tubulação de lançamento para os corpos receptores. Quando os terrenos se situam em cotas abaixo do nível do mar, é necessária a garantia de estanqueidade do sistema de forma a impedir um retorno dos efluentes quando na ocorrência de marés altas ou chuvas fortes.

Uma solução nos terrenos de cotas baixas é a adoção decomportas e gradeamentos logo após a saída da tubulação de lançamento para os cursos d'água. Isto, além de melhorar o desempenho do sistema por evitar o refluxo da 
água também impede o ingresso de lixo para o sistema. Isso também indica o respeito ao meio ambiente, pois com o refluxo pode ocorrer a mistura de materiais orgânicos e lixo no sistema. E isso provocará o encaminhamento de detritos ainda não estabilizados de volta para o corpo receptor e, dessa forma, materiais com alto grau de contaminação de orgânicos, tornando o sistema deficiente.

Esta mistura, ao retornar para os corpos receptores impacta o meio ambiente, gerando a sua degradação. Além disso, fará com que a operacionalização da fossa séptica seja reiniciada, pois haverá alteração na estabilização das reações bioquímicas e para que volte a funcionar de forma adequada precisará ser completamente limpa.

Este problema foi constatado no Complexo Naval da Avenida Brasil, figura 4.13, pois o Rio Meriti traz uma grande concentração de lixo para o desemboque dos efluentes o que, por vezes, impede a saída destes para o corpo hídrico.

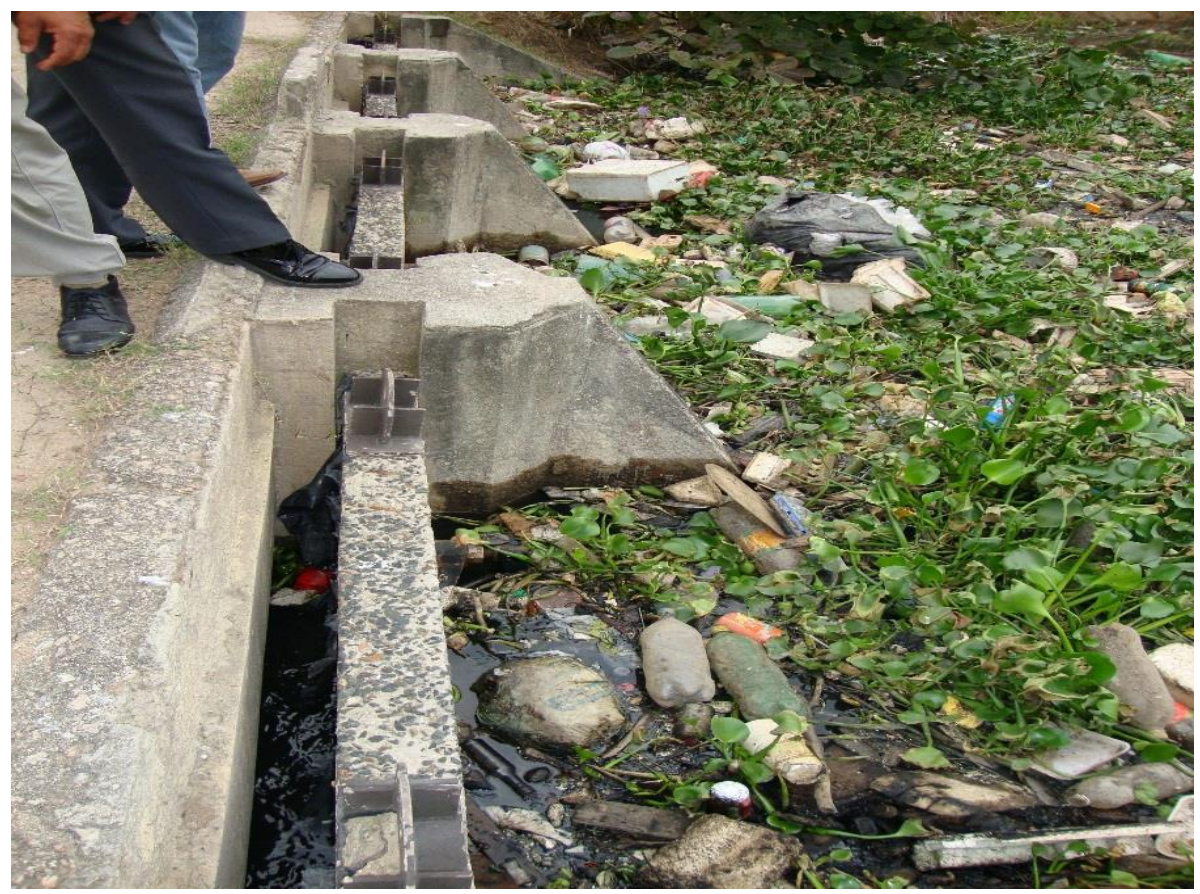

Figura 4.13: Lixo concentrado no gradeamento instalado pelo INEA no Rio Meriti. Fonte: a autora.

Além disso, a comporta existe a jusante da saída, figura 4.14, cuja instalação e manutenção está sob a responsabilidade do INEA, o que impede que a Marinha do Brasil efetue a sua manutenção. Isso gera uma condição de deterioração do sistema, porquanto o lixo, em grande quantidade, quando não 
ingressa no sistema, impede a saída do descarte dos efluentes, bem como a concentração de lixo na saída do sistema impede a sua saída natural pela gravidade.

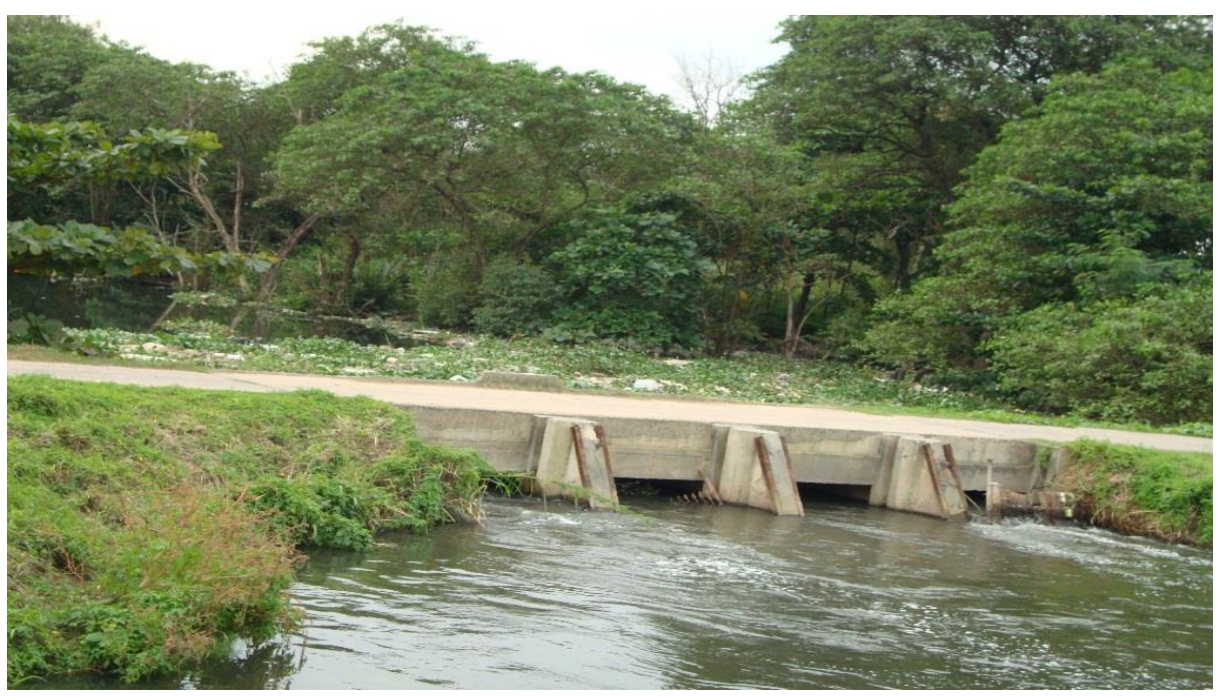

Figura 4.14: Comporta sobre o canal do Rio Meriti e gradeamento parcialmente solto. Fonte: a autora.

Esta comporta é de suma importância para a região, pois quando há maré de sizígia, ou seja uma maré muito alta, a comporta fecha para proteção dos canais das águas do mar. Assim, os alagamentos verificados ao longo dos anos não são exclusivamente provenientes de chuvas, mas sim de fatores conjugados, tais como:

- Chuva com intensidade considerável aliada a maré de sizígia, pois as águas dos canais não são escoadas para o rio Meriti;

- Chuva com intensidade considerável aliada aos canais assoreados da região, pois os canais não suportam o volume das águas e transbordam; e

- Soma dos fatores acima, aliados às cotas baixas da área do grupamento em relação às demais áreas adjacentes.

Para que o sistema de esgoto se torne eficiente, deve-se considerar todas essas interferências, que são decorrência natural da localização dos terrenos de cotas baixas, conjugadas com o incremento da mal resolvida ocupação desordenada do solo, diante do assoreamento dos rios e dos lançamentos diretos de lixo, como exemplificado na figura 4.15. 


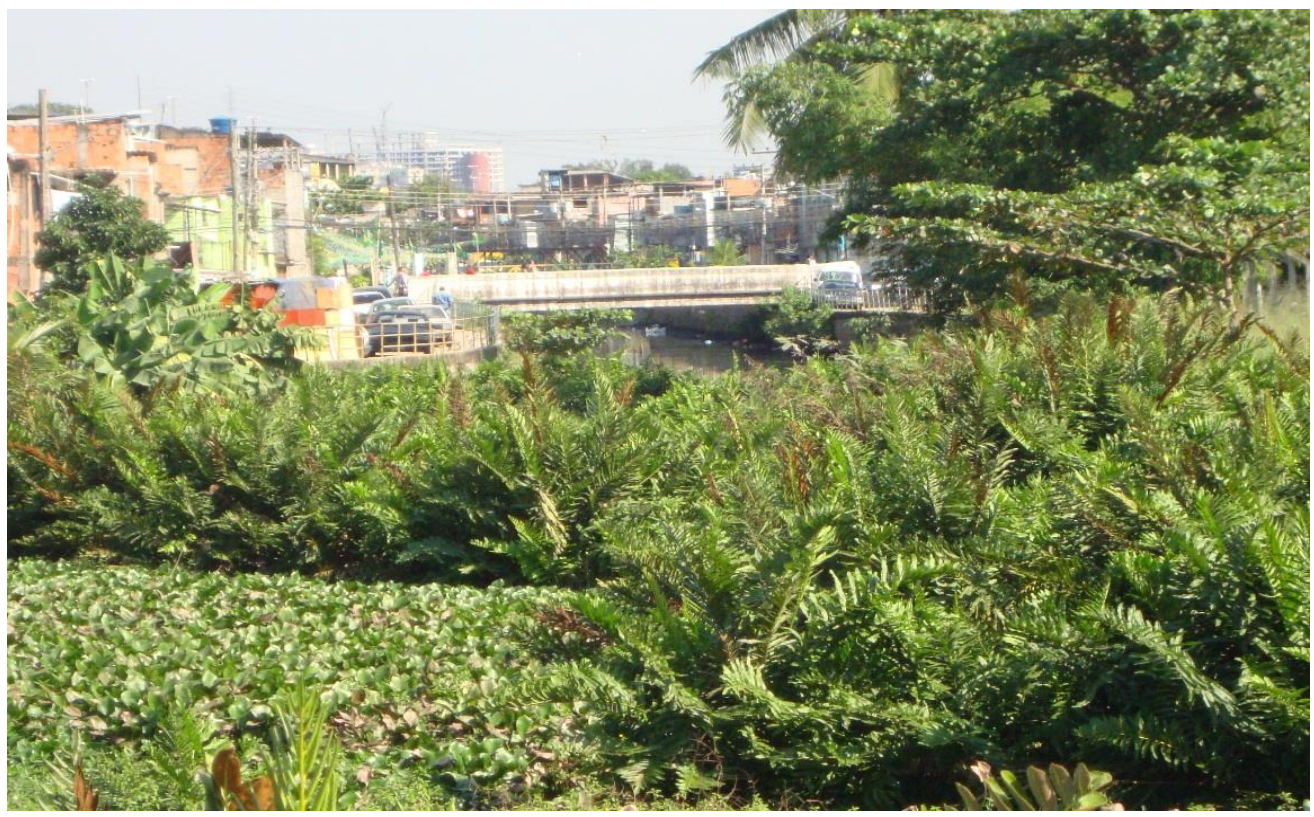

Figura 4.15: Ocupação irregular e assoreamento do Rio Meriti. Fonte: a autora.

Tudo isso sempre ao largo e ao lado dos terrenos da Marinha do Brasil. A ocupação irregular do solo causa assoreamento dos canais e decaimento da taxa de oxigênio o que causa a mortandade de peixes e a proliferação de algas, como indicado na figura 4.16 .

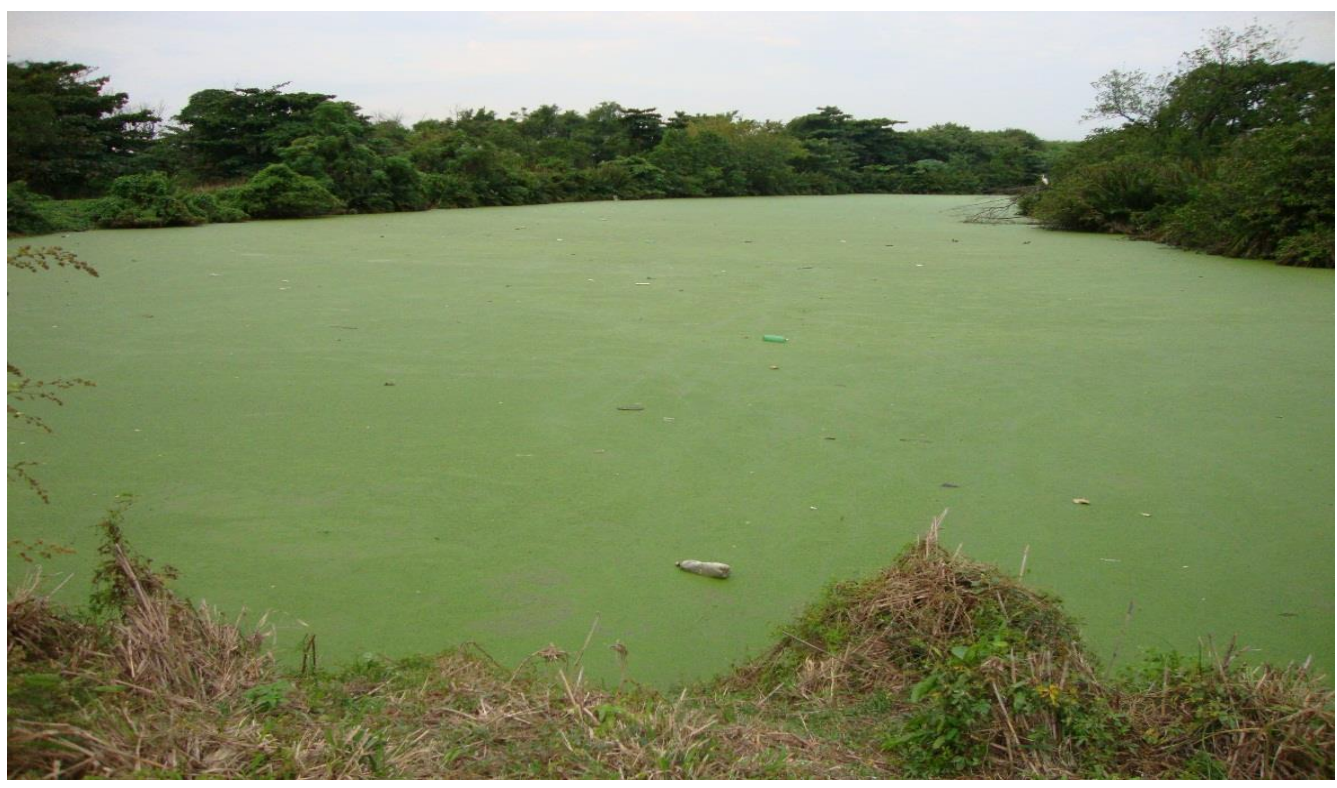

Figura 4.16: Proliferação de algas no Rio Meriti. Fonte: a autora. 


\subsection{5}

\section{Tratamento Preliminar nas Caixas de Gordura}

As caixas de gordura (CG) são compartimentos que se destinam a separar parte da gordura que é despejada pelos dejetos da cozinha. Os líquidos que seguem são direcionados para uma caixa de inspeção (CI) e, em seguida, encaminhados para o sistema de tratamento e descarte de esgoto.

Seu funcionamento é muito simples. Agindo pelo tempo de concentração da gordura na parte superior do líquido despejado, por ser de menor densidade, permite que os líquidos com menor concentração da gordura passem sem essa camada grosseira. Assim, como as gorduras se aglomeram, alteram o tempo de detenção dos efluentes, cuja velocidade pode ser medida por um cilindro graduado com a observância do tempo que levou para se formar a escuma, nome dado à camada de gordura que fica flutuando na parte de cima.

Conforme informado por JORDÃO e PESSOA (2011, p. 213):

\footnotetext{
A necessidade de remoção da gordura contida nos esgotos está condicionada aos problemas que esse material traz às unidades de um sistema de esgoto unitário, se presente em grandes proporções. Assim sendo, a remoção da gordura tem as seguintes finalidades:

- evitar obstrução dos coletores;

- evitar aderências nas peças especiais do sistema de esgoto;

- evitar acúmulo nas unidades de tratamento provocando odores desagradáveis e perturbações no funcionamento dos dispositivos de tratamento; e

- evitar aspectos desagradáveis nos corpos receptores.
}

Usualmente, a unidade de remoção de gordura aplicada nos projetos da Marinha do Brasil é a caixa de gordura, sendo instalada em decorrência dos refeitórios existentes em quase a totalidade dos quartéis. Existem diversos modelos de caixa de gordura, várias já disponíveis prontas para aquisição em fornecedores de acordo com o fluxo dos líquidos.

A forma de manutenção das caixas de gordura também é simples, pois necessita apenas de uma limpeza periódica e a remoção da gordura em uma periodicidade determinada, conforme os lançamentos e o dimensionamento efetuado. Um exemplo são as caixas de gordura da Unidade de Fabricação de Estruturas Metálicas (UFEM), em Itaguaí, que é limpa de 15 em 15 dias, pois há grande movimento de gordura. Inicialmente, houve a projeção de uma limpeza mensal, mas verificou-se, quando entrou em operação, que o ideal era reduzir este 
tempo para a metade, a fim de aumentar o desempenho do sistema, diminuindo odores e insetos em seu interior. Vide as caixas nas figuras 4.17 e 4.18.

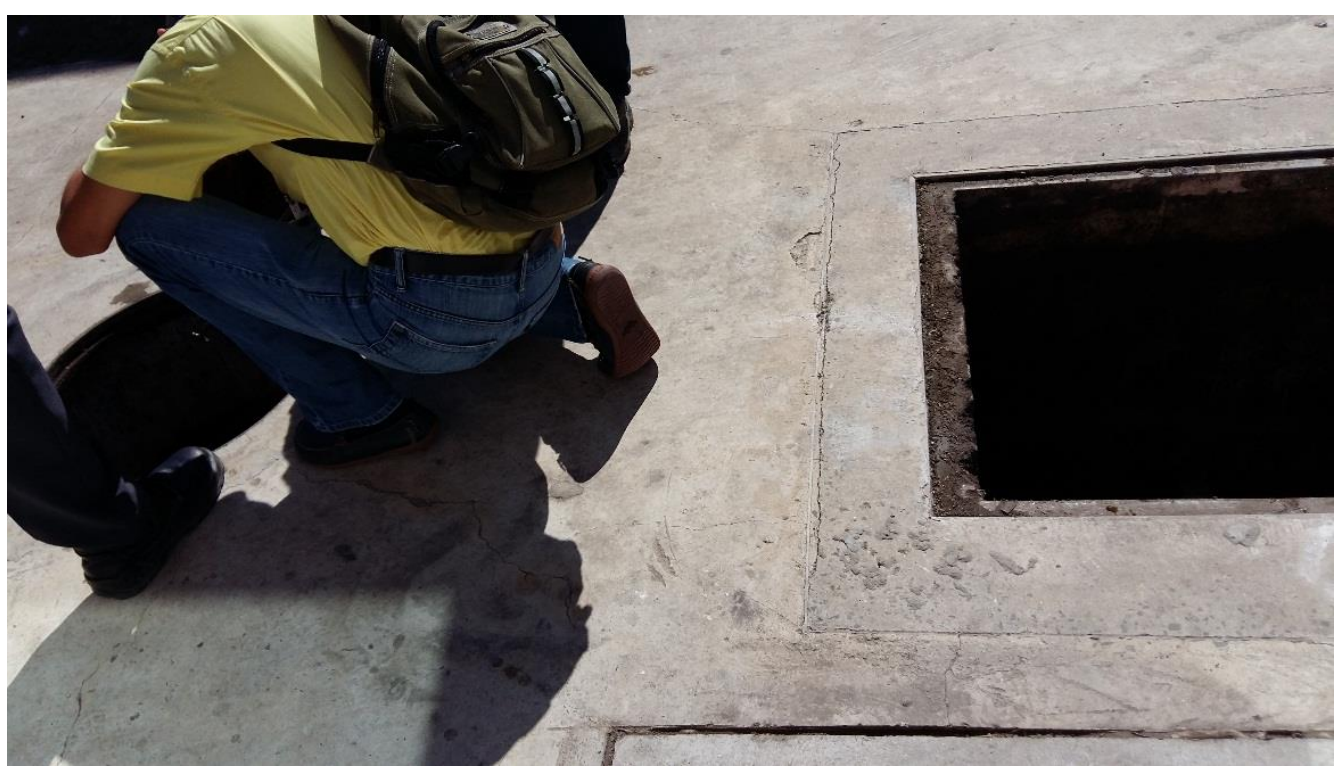

Figura 4.17: Inspeção da Caixa de Gordura da UFEM. Fonte: a autora.

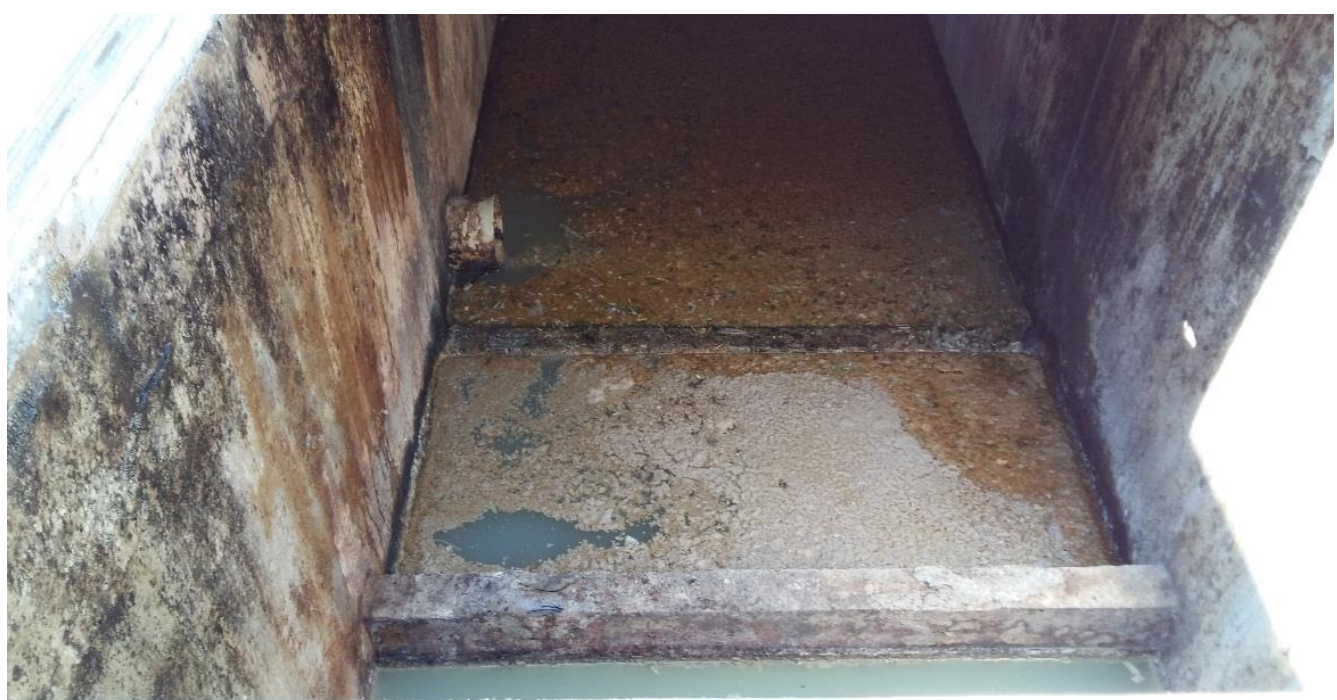

Figura 4.18: Vista interna da Caixa de Gordura da UFEM. Fonte: a autora.

Após observar as inúmeras vezes que o sistema foi atingido em sua eficiência, pelo lançamento reiterado de materiais de grande porte, como ossos, carcaças de animais, dentre outros, especialmente quando ocorre a retirada da tampa do ralo da cozinha, é que a equipe de projetistas da DOCM decidiu inserir no sistema um tratamento preliminar. Destaque-se o Arquiteto Pellegrino, técnico 
que permaneceu como projetista de instalações hidrosanitária por 25 anos na DOCM e que concebeu originalmente a ideia.

Os tratamentos dos afluentes podem ter vários níveis de diminuição das cargas orgânicas. O tratamento preliminar, primário, secundário e terciário. O tratamento preliminar, define BRITTO (2004, p. 53) é a:

Fase de preparação para o tratamento propriamente dito, onde a redução da BDO é desprezível. Consiste apenas em remover sólidos grosseiros, sólidos flutuantes e areia (matéria inorgânica). Pode constatar de:

- grades, crivos ou desintegradores (remoção de sólidos grosseiros);

- caixas de areia (remoção de areia);

- unidades de remoção de flutuantes (remoção de sólidos flutuantes, flotáveis ou superficiais).

Em razão do problema constatado, a ideia foi instalar uma caixa retentora de sólidos (CRS), com o fim de reter os materiais sólidos de grande porte por meio de um gradeamento. Esta caixa passou a proteger o sistema contra entupimentos e garantiu que a separação entre a gordura e o líquido ocorresse da forma esperada.

Assim, procedeu-se a recomendação, para os projetos e para as vistorias que são efetuadas para verificar os problemas no sistema de coleta nos esgotos, de inserir antes da caixa de gordura uma caixa retentora de sólidos e manter a tampa do ralo fixada nas cozinhas.

A caixa retentora de sólidos possui uma grade a fim de evitar que materiais de grande porte ingressem no sistema, o que impede os entupimentos e a alteração das reações bioquímicas esperadas para a caixa de gordura. Segue-se um exemplo, indicado na figura 4.19, da caixa retentora de sólidos, a ser instalada antes das caixas de gordura: 


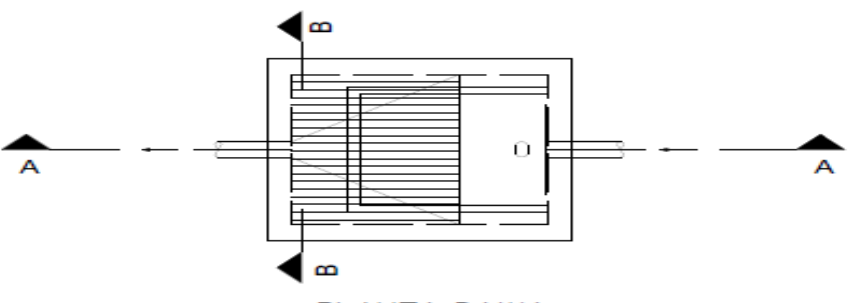

PLANTA-BAIXA

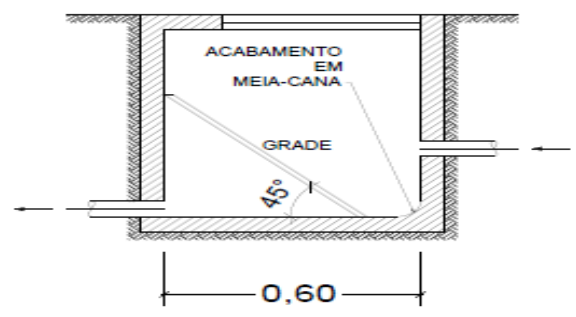

CORTE A-A

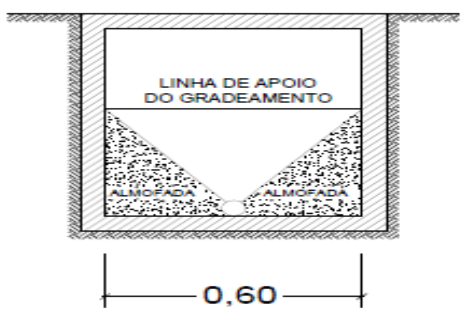

CORTE B-B

Figura 4.19: Tratamento preliminar com Caixa Retentora de Sólidos. Fonte: a autora.

Com esta solução, o sistema passou a funcionar de forma eficiente, o que melhorou o seu desempenho. É importante perceber que esta caixa retentora de sólidos, assim como as caixas de gordura, deve ser limpa periodicamente, a fim de permitir a sua funcionalidade.

\subsection{6}

\section{Procedimentos Sugeridos}

A fossa séptica seguida de um tratamento por filtro anaeróbio de fluxo ascendente (FAFA) é uma solução usual na Marinha do Brasil e que aponta como uma solução de baixo custo, por ser de execução simples e econômica.

Todavia, para uma progressiva modernização do sistema de esgoto da Marinha do Brasil, deve-se envidar esforços para que sejam as redes ou ligadas aos troncos coletores, caso ali existam, ou que sejam instaladas Estações Compactas de Tratamento de Esgoto, que são de baixo custo, quando comparado o seu custo-benefício em razão da eficiência de seu conjunto.

A sedimentação com deterioração dos materiais de forma anaeróbia, seguida de filtração com fluxo ascendente, pelas bolhas formadas que impulsionam para a superfície, e de um processo de acúmulo do lodo somam uma eficiente forma de tratamento, que deve ser uma solução técnica a ser 
gradativamente implementada para a modernização do sistema de esgoto da Marinha do Brasil.

Segue-se um exemplo de ETE compacta, figura 4.20, que usa dois compartimentos apenas. Um primeiro para o tratamento anaeróbio e o segundo para tratamento aeróbio.

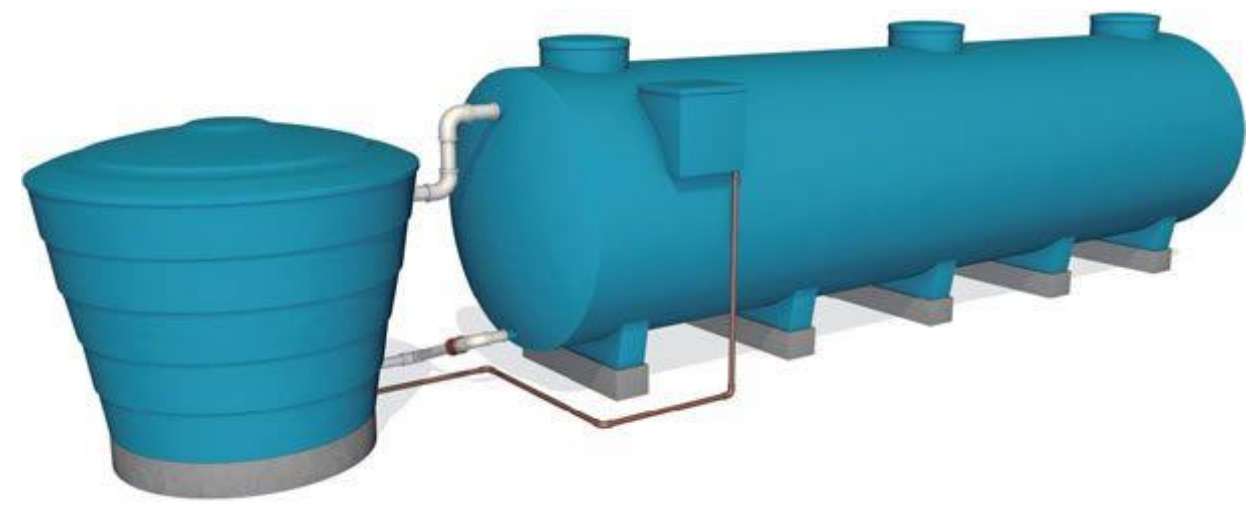

Figura 4.20: ETE compacta. Fonte: http://construcaomercado.pini.com.br.

Para que se permita um bom desempenho do conjunto fossas sépticasfiltro anaeróbio de fluxo ascendente (FAFA), deve-se observar diversos cuidados para evitar que, embora os materiais para carreados para a fossa não sejam contaminantes, que outros materiais contaminados possam acessar o seu interior. Para isso, sugerem-se alguns procedimentos, tais como:

- fazer um desenho com a localização da fossa séptica e de seus tubos de acesso, a fim de saber onde se encontra exatamente o seu desemboque;

- evitar plantas de raiz muito profundas em áreas próximas, assim como outras atividades que possam ser prejudiciais ao sistema;

- manter um registro de limpezas, inspeções e outras manutenções, sempre incluindo nome, endereço e telefone dos técnicos e empresas que efetuaram os serviços;

- no caso de locais de difícil acesso, manter uma equipe treinada para efetuar a limpeza, com a previsão de aquisição dos equipamentos de proteção individual (EPI) adequados e em número suficiente para a programação de limpeza, bem como destinar uma área restrita para a secagem do lodo retirado;

- manter a área do entorno da fossa limpo, evitando-se, inclusive que seja coberta com grama ou relva; 
- não aproveitar o espaço de terreno para criar estacionamento, a fim de que o terreno não ceda sobre a fossa séptica, bem como impedir que equipamentos pesados sejam colocados no local;

- do mesmo modo, não permitir a construção de piscinas e calçadas perto da fossa séptica;

- manter a fossa séptica estanque, impedindo o acesso das águas da chuva, por meio de construção de comportas junto à saída da tubulação de saída dos afluentes. Além disso, manter uma grade na saída da tubulação a fim de evitar o ingresso de lixo no sistema;

- manter placas informando para evitar o lançamento de materiais não biodegradáveis no sistema, tais como plásticos, fraldas e absorventes, papel higiênico e guardanapos, já que esses detritos podem encher o tanque e entupir o sistema.

- não permitir que tintas, óleos de motor de automóvel, pesticidas, fertilizantes e desinfetantes entrem no sistema séptico. Essas substâncias podem atravessá-lo diretamente, contaminando os terrenos em volta da fossa séptica, além de afetar a eficiência do sistema pois este fato mata os microrganismos que decompõem os resíduos;

- construir caixas de resíduos sólidos antes das caixas de gordura, a fim de eliminar o lançamento de detritos de grande porte, que afetam o funcionamento de todo o sistema.

Além dos procedimentos acima, nos quartéis que se localizam em áreas de difícil acesso, não havendo condições de contratação dos serviços de limpeza, sugere-se que os próprios militares recebam treinamento para a execução da limpeza e manutenção das fossas sépticas. Tanto quanto possível, essa situação somente deverá ocorrer em casos extremos, porquanto, ainda que estejam disponibilizados os equipamentos de proteção individual (EPI), é fato que esta função não será a única função do militar, sendo que não se pode apressar ou impor condições de execução distintas das que estiverem previstas em um manual disponível na Organização Militar.

Neste manual deverá constar um plano interno de ação periódica, a fim de que tal procedimento se insira no planejamento administrativo anual, especialmente garantindo-se a verba necessária para a aquisição dos materiais de 
apoio como o local para a disposição do lodo, a ser conhecido como leito de secagem, baldes, pás e luvas para a manipulação e transbordo do lodo, dentre outros. 


\section{5 \\ MODERNIZAÇÃO DOS COMPLEXOS NAVAIS DA CIDADE \\ DO RIO DE JANEIRO: contribuição para o programa de despoluição da Baía de Guanabara}

\section{1}

\section{Considerações Iniciais}

Com uma das metas apontada para a melhoria de desempenho do sistema de esgoto, houve uma coincidência entre o planejamento da Marinha do Brasil e o programa de despoluição da Baía de Guanabara. Embora a ideia não seja nova, a sua implementação alcança seu ápice nesta fase em que os jogos olímpicos colocam o país sob uma lupa para os olhos do mundo. E uma das contrapartidas do Brasil como sede olímpica é manter a Baía de Guanabara em condições de recepcionar os jogos aquáticos que ali ocorrerão, com a qualidade que se espera da água. E isto abrange tanto o aspecto físico, como a cor, o odor e a quantidade de detritos que flutuam na água do mar, quanto o aspecto químico, como a quantidade de coliformes fecais e metais ali concentrados, por exemplo.

Existem muitos Complexos Navais que ainda despejam os seus efluentes diretamente nos corpos receptores, cujo sistema principal de solução para o lançamento dos efluentes é a fossa séptica combinada, em regra acompanhada do respectivo filtro anaeróbio de fluxo ascendente (FAFA) para a melhor qualidade final, como apresentado no capítulo 4. Há também alguns Complexos dotados de Estações de Tratamento de Esgoto (ETE), mas a sua manutenção nem sempre se encontra em pleno atendimento, diante das limitações orçamentárias, o que afeta seu bom desempenho. Uma solução viável com bom custo-benefício são as Estações Compactas, que podem ser instaladas progressivamente em substituição ao sistema atual.

Diante do quadro favorável à modernização do sistema de esgoto, e apoiada pela sistemática atual de priorização da União ao apoio dos Jogos Olímpicos, cuja consequência direta é a despoluição dos rios, mares e lagos que sediarão os jogos, a Marinha do Brasil iniciou o processo de modernização do 
sistema de saneamento de diversos Complexos Navais com os recursos recebidos para este fim. A modernização contempla desde a modificação do sistema para um sistema de separação absoluta, com o fim de efetuar a separação da coleta das águas pluviais e dos efluentes do esgoto, situação esta já muito ultrapassada tecnicamente, até o direcionamento de todo o efluente captado para a rede pública ou implantação de ETE, compacta ou não, sendo que as redes públicas já se encontram em expansão para o atendimento das novas demandas. Neste último item, a Marinha do Brasil depende das obras das concessionárias, pois é necessário que sejam disponibilizados os troncos coletores para este fim.

São muitos os problemas que estão sendo enfrentados, e muitas técnicas de proteção ambiental ainda não serão implementadas, mas não há dúvidas de que para se começar algo, deve-se dar o primeiro passo.

\section{2}

\section{O Programa de Despoluição na Baía de Guanabara}

A Baía de Guanabara é uma das bacias hidrográficas do Estado do Rio de Janeiro e pertence à uma macroregião ambiental, segundo a Secretaria do Meio Ambiente - PLANÁGUA SEMADS/GTZ (2001). As macroregiões ambientais, conforme definidas em Decreto ${ }^{\circ}$ 26.058 (RIO DE JANEIRO, 2000), dividem-se entre parte terrestre e outra marinha, sendo que uma parte terrestre compreende uma ou mais bacias hidrográficas. A porção marinha engloba a zona costeira, incluindo baías, enseadas, praias, ilhas, costões rochosos, mangues e uma faixa de mar aberto, cuja largura é definida de acordo com critérios estabelecidos no Plano Nacional de Gerenciamento Costeiro, instituída pela Lei no 7.661 (BRASIL, 1980).

Para se ter uma ideia da dimensão do problema da poluição, exemplificado na figura 5.1, a Baía de Guanabara possui uma superfície de aproximadamente $381 \mathrm{~km}^{2}$, comporta um volume de água de 3 bilhões de metros cúbicos, tem um perímetro de $131 \mathrm{~km}$ e sua bacia hidrográfica compreende uma superfície de $4.081 \mathrm{~km}^{2}$. Além disso, possui uma topografia diversificada, sendo constituída por planícies, das quais se destaca uma grande depressão denominada baixada fluminense, área de grande concentração populacional de baixa renda, e 
pelas colinas e maciços costeiros e escarpas da Serra do Mar, que ainda são mais preservadas.

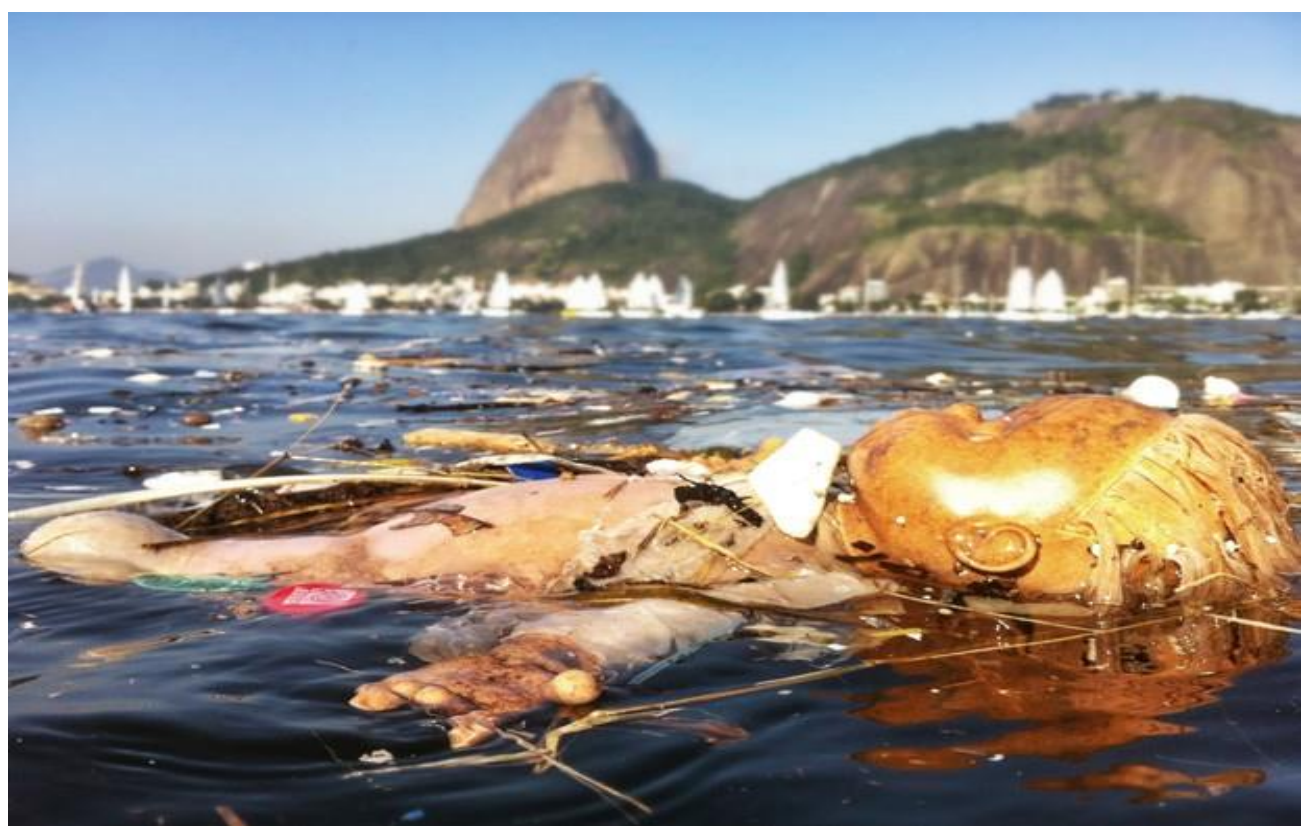

Figura 5.1: Vista da Baía de Guanabara. Fonte: http://www.aquafluxus.com.br/rio-450anos-a-guanabara-nao-esta-em-festa/.

Os elementos que identificam a divisão de águas têm início no Pão de Açúcar e prosseguem pelas cristas das Serras. São elas: Serra da Carioca, dos Maciços da Tijuca e Pedra Branca e pelas Serras de Madureira-Mendanha, Tinguá, do Couto, da Estrela, dos Órgãos, Macaé de Cima, Santana, Botija, Sambê, Barro de Ouro, Sapucaia, Caçorotiba, Tiririca e Grande, tendo seu trecho final no Morro da Viração, em Niterói, nas proximidades da Fortaleza de Santa Cruz.

A área de drenagem contribuinte à Baía de Guanabara limita-se a sudoeste com as bacias hidrográficas da baixada de Jacarepaguá e da Lagoa Rodrigo de Freitas; a oeste com a Bacia da Baía de Sepetiba, ao norte com a Bacia do Rio Paraíba do Sul (Rios Piabanha e Dois Rios); a leste com as bacias dos Rios Macaé e São João e a sudeste com as bacias das lagunas de Piratininga - Itaipu e Maricá.

Portanto, se houvesse uma concepção correta de limitação de permeabilidade dos solos, a drenagem estaria preservada. O que não é a realidade dos planejamentos urbanos, que concedem o excesso construtivo por meio de especulação imobiliária, que gera a verticalização descontrolada. Dessa forma, o excesso construtivo nestas áreas está interferindo diretamente na drenagem natural, o que deveria ser respeitado podendo ocorrer um processo de urbanização 
excessiva prejudicial ao meio ambiente e a todos os cidadãos. Além disso, já existe um processo de posse nas áreas adjacentes aos rios, o que tem incrementado a degradação das áreas naturais, justamente por uma ocupação irregular do solo, o que indica um descontrole nas consequências ao meio ambiente.

A bacia hidrográfica da Baía de Guanabara abarca os maiores centros urbanos e concentra mais de $70 \%$ da população fluminense, bem como a maioria das indústrias de maior porte, contendo 16 municípios, sendo que 10 se encontram integralmente dentro da bacia e 6 se encontram apenas parcialmente na bacia.

Assim, os municípios que se encontram integralmente dentro da bacia são: Duque de Caxias, Mesquita, São João de Meriti, Belford Roxo, Nilópolis, São Gonçalo, Magé, Guapimirim, Itaboraí e Tanguá. Encontram-se apenas parcialmente dentro da bacia os municípios do Rio de Janeiro, Niterói, Nova Iguaçu, Cachoeiras de Macacu, Rio Bonito e Petrópolis. Todos estes municípios estão crescendo mais do que podem suportar, tanto em geração de lixo e esgoto sanitário, quanto no consumo de serviços públicos como abastecimento de água e luz. O resultado é a poluição desregrada, as faltas de água e de luz, e os bairros que ainda não possuem coleta dos seus efluentes de esgoto.

Composta de 50 rios e riachos, sendo os principais os Rios Macacu, Iguaçu, Estrela e Sarapuí, o fato é que os corpos receptores não se encontram mais vivos, sem qualquer possibilidade de ocorrência de processo de autodepuração. Sobre o processo de autodepuração, certo é que este processo natural já não se encontra mais em atividade, como exposto no capítulo 4, e é uma questão de tempo a morte dos rios. O lançamento dos efluentes na Baía de Guanabara é, então, um processo que deve ser controlado de forma rigorosa, para que não piore a situação de suas águas já poluídas. Pior: para que não aumente a incidência de doenças pelas cidades.

As imensas áreas urbanizadas resultaram na retificação e canalização com concreto de centenas de quilômetros de cursos de água. Este processo inviabiliza ainda mais a sobrevivência dos rios. Considera-se a água um recurso renovável. Entretanto, este conceito é relativizado pela disponibilidade real de sua oferta adequada. $\mathrm{O}$ que se quer dizer é que se a água existir em quantidade, mas não existir a possibilidade de seu uso real, ela deve ser considerada não renovável. Portanto, utilizar os recursos hídricos sem qualquer planejamento, ou sem a sua proteção, é eliminar a sua disponibilidade. 
Segundo dados contidos na Agência Nacional de Águas (ANA, 2010) e como informa SETTI et al (2001), a quantidade de água total estocada na terra tem sido a mesma nos últimos 500 milhões de anos, em um valor total estimado de 1.386 milhões de $\mathrm{km}^{3}$. Deste total, apenas $2,5 \%$ é formado por água doce. $\mathrm{E}$ desta água doce, $68,7 \%$ estão armazenados nas calotas polares ou nas geleiras. Portanto, cuidar da água doce disponível é uma necessidade para a existência da vida. E tudo isso ainda depende do ciclo hidrológico que pode causar abundância ou escassez local, o que tem relação direta com as alterações climáticas, fato este que já está se demonstrando uma grande preocupação no Brasil. Ainda segundo a ANA (2010), os princípios orientadores do uso, controle e proteção das águas foram sintetizados por Veiga da Cunha et al. (1980), como abaixo:

A avaliação dos benefícios coletivos resultantes da utilização da água deve ter em conta as várias componentes da qualidade de vida: nível de vida, qualidade de vida, condições do ambiente.

Para o presente estudo, a condição do ambiente é um dos componentes da qualidade de vida que tem relação direta com a destinação dos efluentes do esgoto da Marinha do Brasil para os corpos receptores. Dentre os programas políticos que se coadunam com a ideia de controle e gestão dos recursos hídricos se encontra o Programa de Despoluição da Baía de Guanabara (PDBG). Este programa tem por fim a melhoria das condições sanitárias e ambientais da Região Metropolitana do Rio de Janeiro. E esta finalidade pretende incidir na melhoria da qualidade de vida da população local, pois a despoluição da Baía de Guanabara e áreas adjacentes representa melhoria em vários sentidos, seja na oferta de água de consumo de melhor qualidade, seja na oferta de águas de boa qualidade para o uso esportivo, seja no próprio âmbito da saúde e do conforto visual.

Este programa não é ideia nova. Tendo sido planejado e elaborado no início da década de 90, com a finalidade de planejar, coordenar e executar um conjunto de ações ordenadas que formem um bloco de ações que atuem diretamente na despoluição da Baía, abrangendo tanto os procedimentos de engenharia, quanto de gestão e planejamento.

Até o início do ano de 2015, segundo a CEDAE (2015), foi investido no PDBG o valor total de $\mathrm{R} \$ 1.796 .397 .398,40$, cabendo a essa concessionária a responsabilidade pela execução das obras dos Sistemas de Abastecimento de Água 
e Esgotamento Sanitário, mediante repasse de recursos financeiros do próprio Estado do Rio de Janeiro ou de empréstimos internacionais.

As obras integrantes dos Sistemas de Abastecimento de Água foram concluídas pela atual administração, permanecendo em curso as relativas ao Sistema de Esgotamento Sanitário. Embora na contramão das dificuldades financeiras, o Governo do Estado do Rio de Janeiro recebeu da JICA - Japan International Cooperation Agency uma manifestação positiva sobre a atuação da NOVA CEDAE na execução do Programa de Despoluição da Baía de Guanabara - PDBG. Ocorre que, com a crise financeira agravada, as obras passaram a ter um ritmo mais lento sem, entretanto, paralisarem.

Muitas das melhorias no sistema de esgoto afetaram ou irão afetar diretamente a Marinha do Brasil. Isto porque a disponibilidade superveniente dos troncos coletores de esgoto sanitário passa a gerar a obrigação da Marinha do Brasil de modernizar o seu sistema de descarte dos efluentes, que hoje são, em regra, efetuados por fossas sépticas e filtros anaeróbios, como visto no capítulo 4 , e que deverão sofrer uma nova interligação para que sejam integralmente descartados na nova rede pública, disponibilizada em decorrência do Programa de Despoluição da Baía de Guanabara, além de serem transformados em um sistema de separação absoluta, como determina a norma técnica NBR 8160/1999:

4.1.3.1 - O sistema predial de esgoto sanitário deve ser o separador absoluto em relação ao sistema predial de águas pluviais, ou seja, não deve existir ligação entre os dois sistemas.

4.1.4 - A disposição final do efluente do coletor predial de um sistema de esgoto sanitário deve ser feita:

a) em rede pública de coleta de esgoto sanitário, quando ela existir;

b) em sistema particular de tratamento, quando não houver rede pública de esgoto sanitário.

Portanto, com a implementação do PDBG, a Marinha do Brasil, até mesmo para atendimento das normas vigentes, deverá efetuar a interligação de seus efluente às redes públicas. 


\section{3}

\section{Estudos de Caso}

Com a implementação do PDBG, surgiram recursos financeiros para que a Marinha do Brasil também modernizasse os seus Complexos Navais com efluentes que se destinam para os corpos hídricos receptores nos quais ocorrerão algumas modalidades olímpicas. Com um sistema de tratamento e descarte dos efluentes executados, majoritariamente, por fossas sépticas e filtros anaeróbios, ocorre o lançamento para os rios adjacentes de grande número de carga orgânica, o que pode ser minimizado com uma melhoria do sistema, por coleta direta pela concessionária local. Aliás, muitos dos corpos receptores já se encontram biologicamente mortos, ou seja, sem qualquer capacidade de autodepuração, o que é uma situação crítica que independe do lançamento ou não de efluentes, muito embora seja certo que quanto menor for a carga orgânica lançada nestes corpos receptores, tanto menor é o custo para a sua revitalização e maior é a probabilidade de que sejam recuperados.

Dentro da programação de recursos existentes, a Marinha do Brasil priorizou a modernização de seus principais Complexos Navais na cidade do Rio de Janeiro, contribuintes junto a corpos receptores e situados em área de grande concentração urbana. Destacam-se os estudos de caso que serão descritos a seguir, sendo certo que neste trabalho denomina-se Complexo Naval um conjunto de órgãos militares, compostos por inúmeras edificações, localizados em uma delimitação militar, cuja divisão é meramente administrativa.

\subsection{1}

\section{Complexo Naval da Ilha das Cobras}

Neste Complexo Naval, situado no Arsenal de Marinha no Rio de Janeiro (AMRJ), figura 5.2, decidiu-se implementar uma obra do anel hidrosanitário que direcionará os efluentes para a rede pública. 


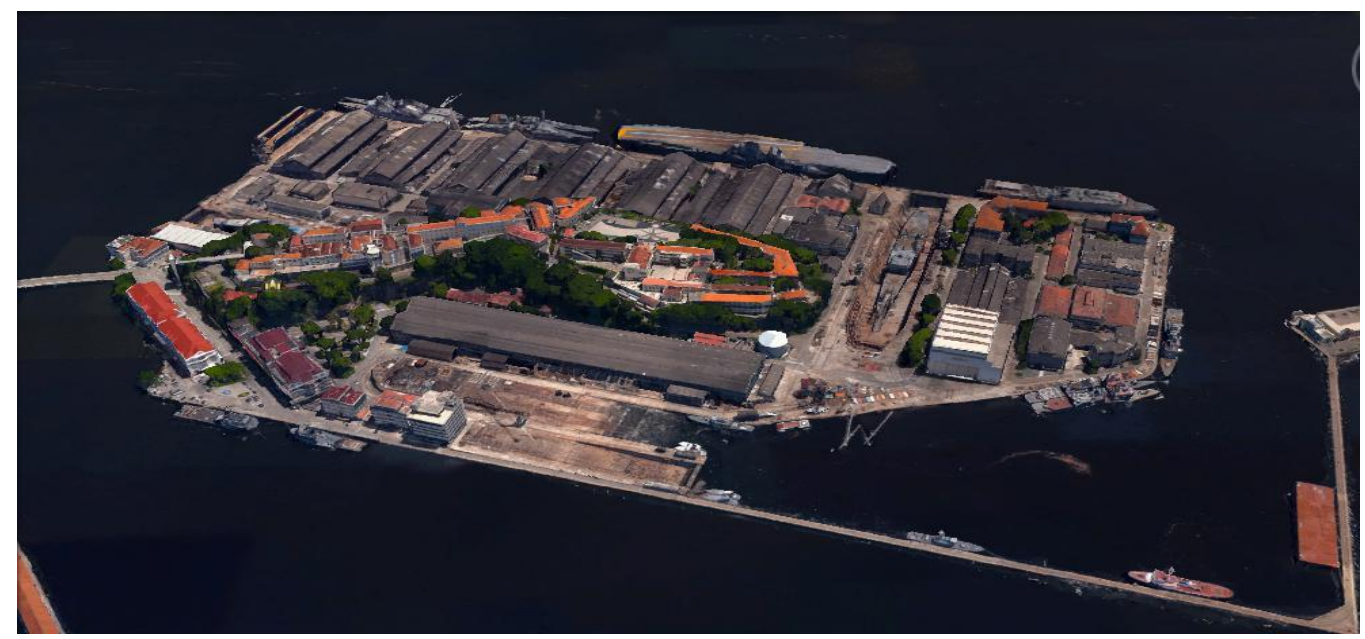

Figura 5.2: Vista do Arsenal de Marinha. Fonte: Google Earth. Acesso em 10 out 2015.

Esta obra vai ao encontro dos anseios da Marinha do Brasil de atuar ativamente na prevenção e proteção do meio ambiente, sendo parte de um plano de revitalização que pretende eliminar qualquer despejo de efluente no meio ambiente, especificamente na Baía de Guanabara, herança de planejamento pretérito que se coadunava com a concepção de engenharia da época em que foi construído. Esta revitalização também adequa as instalações à legislação ambiental.

Como se trata de órgão público, se faz necessária a execução prévia de licitação. Assim, no ano de 2011 foi executado o Processo de Licitação $n^{\circ}$ 40004/11-6, dando origem ao contrato $\mathrm{n}^{\circ} 41.000 / 2011-229 / 00$, cujo objeto é a obra de adequação do anel hidrossanitário do Complexo Naval da Ilha das Cobras (CNIC), com prazo de execução inicial de 900 (novecentos) dias, no período de 18 de novembro de 2011 a 06 de maio de 2014.

Como já foi apresentado no capítulo 2, por diversas razões, incluindo-se alteração de projeto e de itens de execução, houve modificação do término do prazo de execução do contrato postergada para o ano de 2015. Este problema foi consequência de diversos fatores, que sempre põe em risco a rapidez e eficiência do processo administrativo.

Um dos principais problemas para a conclusão das obras é a cooperação da CEDAE, tendo em vista que a entrega dos efluentes pelo anel hidrossanitário é efetuada em uma rede de coleta pública, de competência daquele órgão público, cujo sistema coletor ainda não comporta o recebimento do fluxo de efluentes do novo anel. O sistema coletor existente foi construído em 2008 pela Companhia 
Estadual de Água e esgoto (CEDAE) e necessita também de modernização para a adequação ao novo fluxo de recebimento de efluentes.

Esta ligação à rede pública transportará os efluentes para a Estação de Tratamento de Esgoto (ETE) Alegria, que desde janeiro de 2009 opera com tratamento a nível secundário, onde as águas residuais passarão a apresentar um reduzido nível de poluição por matéria orgânica, adequando-se ao posterior lançamento no corpo receptor.

Agindo em consonância com os recursos recebidos e com o plano de revitalização do Complexo Naval da Ilha das Cobras, a Marinha está envidando os seus esforços para realizá-lo integralmente o mais rápido possível.

O plano de revitalização compreende diversas atividades, são elas:

a) conexão das redes de esgoto por meio de um anel hidrossanitário, cujos efluentes serão recalcados pelas estações elevatórias (EE) a serem construídas para permitir o fluxo ascendente dos líquidos até o novo tronco coletor da CEDAE, disponibilizado próximo ao Comando do Primeiro Distrito Naval, órgão da Marinha do Brasil, localizado na Praça Mauá.

Este tronco coletor irá efetuar a captação dos efluentes do Comando do Primeiro Distrito Naval, provenientes dos edifícios do Arsenal de Marinha e das demais Organizações Militares que compõem o Complexo Naval da Ilha das Cobras, tal como Hospital Central da Marinha, Presídio da Marinha e Batalhão Naval.

b) conexão de caixas coletoras, localizadas ao longo dos cais, às saídas de esgoto dos Navios (em média, cerca de 25 (vinte e cinco) navios podem ser atracados ao longo dos cais do Arsenal).

Esta facilidade portuária permite que a embarcação não precise utilizar o sistema de tratamento de esgoto de bordo, nem tampouco descartar os efluentes na Baía de Guanabara.

O anel hidrosanitário abrange movimentos de terra, pavimentações, além, é claro, da instalação de tubulações para o encaminhamento dos efluentes e de 
construção de estações elevatórias. O valor total estimado envolvido é da ordem de 10 (dez) milhões de reais.

Sendo uma das mais importantes intervenções a serem realizadas, a modernização abrange a construção de 7.542 metros lineares de rede em PVC, de alta resistência, entre 150 e $400 \mathrm{~mm}$ com a cota de instalação de aproximadamente 2,5 m, a construção de quatro (04) elevatórias e de 150 poços de visita e a demolição de, aproximadamente, $45.582 \mathrm{~m} 2$ de calçamento em paralelepípedos.

Isto tudo deve ser executado sem a paralização dos serviços, o que implica em rigorosa implementação logística de canteiros de obras e adequada distribuição da execução dos serviços, com a observância da rotina diária de passagem de automóveis e travessia de pessoas, atracação de navios, além de materiais sensíveis que são utilizados para consumo nas cozinhas e que não podem sofrer interrupção do fornecimento nem contaminação dos produtos.

Durante a execução dos serviços, muitas foram as interferências encontradas. Quase todas refletem na concepção do projeto inicial e implicam na alteração do projeto por necessidade superveniente, com fatos novos encontrados durante a construção do objeto. No caso do anel hidrossanitário, destacam-se:

- a necessidade de readequação da metodologia construtiva das estações elevatórias (EE), em função da profundidade das escavações, pois a profundidade prevista eram menor do que a necessária para que houvesse o transporte dos efluentes com a vazão e velocidade necessárias para vencer a distância a ser percorrida;

- existência de alteração no volume de escavação, devido às interferências encontradas ao logo do percurso, como malha de redes não mapeadas e estruturas antigas que corroboraram para o afundamento da vala de assentamento das tubulações e, consequentemente, também maiores cota de fundo das elevatórias, uma vez que o esgoto segue para as elevatórias por desnível.

Aliada a esta nova fase de modernização, ocorreu neste ano de 2015 a celebração de contrato entre as empresas DCNS e AMI-BRASIL (subsidiaria da GE na América do Sul), com a interveniência da Marinha do Brasil, através do Arsenal de Marinha do Rio de Janeiro, a ser custeado com recursos oriundos do Contrato de OFFSET do Programa de Desenvolvimento de Submarino com Propulsão Nuclear (PROSUB), gerenciado pela COGESN, com o fim de dar 
andamento às etapas de modernização do Sistema de Esgotamento do Complexo do Arsenal de Marinha.

Desta forma, será modernizado o sistema de captação de esgoto do Dique Almirante Régis, figura 5.3. A implementação deste projeto, com prazo estimado de um ano, visa conferir melhores condições de segurança e maior confiabilidade nas operações de docagem no maior dique da $\mathrm{MB}$, considerando o elevado valor estratégico para a prontidão operativa dos Meios Navais.

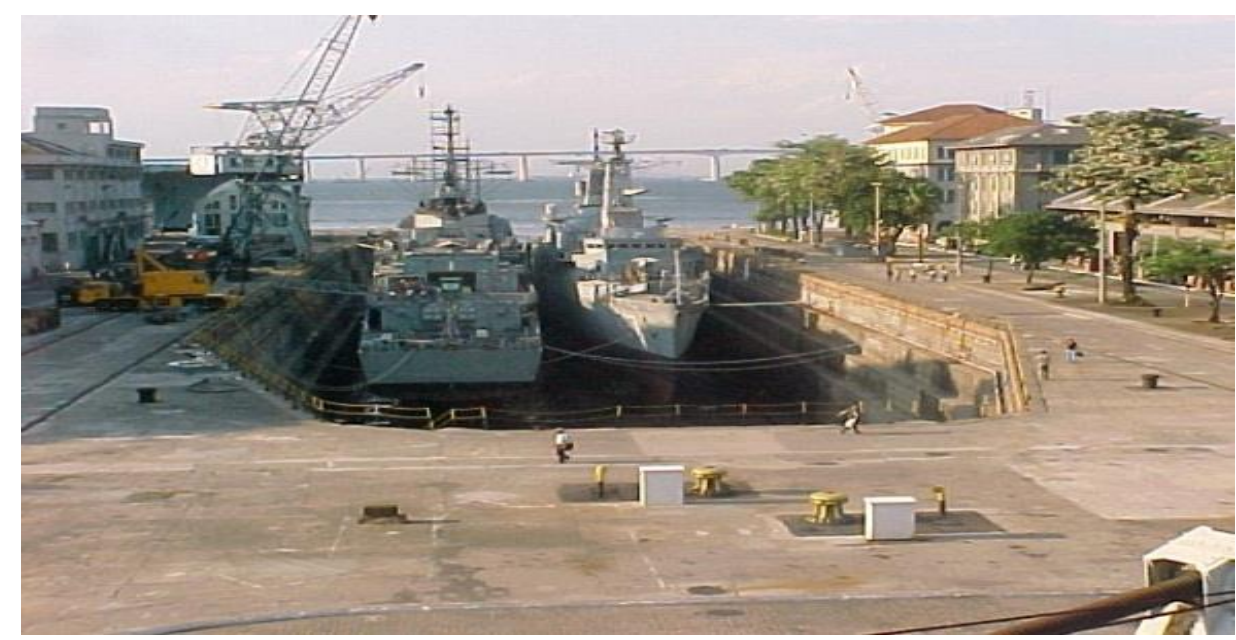

Figura 5.3: Dique Almirante Régis. Fonte: https://www.mar.mil.br/amrj/images/.

\section{3 .2}

\section{Complexo Naval na Avenida Brasil}

Da mesma forma, e seguindo a linha de ação que visa ao anseio da Marinha do Brasil de atuar ativamente na prevenção e proteção do meio ambiente, outro plano de revitalização que pretende eliminar os despejos de efluente no meio ambiente, especificamente na Baía de Guanabara, é a modernização do sistema de esgoto no Complexo Naval da Avenida Brasil.

Assim sendo, a Marinha desenvolveu um projeto que abrange as Organizações Militares (OM) componentes do Complexo Naval da Avenida Brasil, tais como o Grupamento de Fuzileiros Navais no Rio de Janeiro (GptFNRJ), a Casa do Marinheiro (CMN), o Centro de Instrução Almirante Alexandrino (CIAA), a Liga de Esporte do Arsenal da Marinha (LESPAM), a Casa dos Marinheiros (CMN), Centro de Educação Física Almirante Adalberto Nunes 
(CEFAN), Base de Abastecimento da Marinha no Rio de Janeiro (BAMRJ) e Centro de Instrução Almirante Graça Aranha (CIAGA).

A revitalização adequa as edificações ali existentes à legislação ambiental, às normas técnicas e modernizam o sistema. Esta obra também depende da disponibilização do tronco coletor pela CEDAE, já que esta obra é de sua responsabilidade. Por isso, ainda que a Marinha do Brasil conclua toda a infraestrutura sanitária no complexo naval da Avenida Brasil, figura 5.4, somente poderá iniciar as suas atividades de descarte para a rede pública quando esta estiver disponível para tanto.

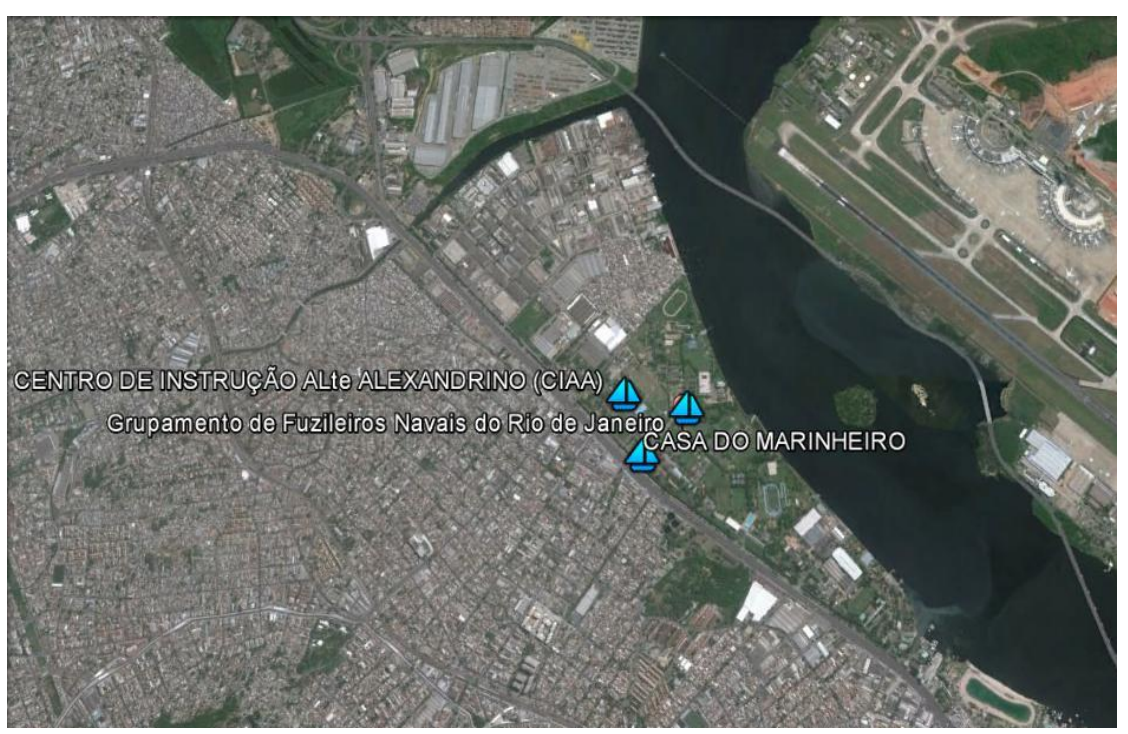

Figura 5.4: Vista de parte do Complexo Naval da Av. Brasil. Fonte: Google Earth. Acesso em 10 out 2015.

A obra de modernização do Complexo Naval da Avenida Brasil abrange:

- 2 (duas) estações elevatórias

- 99 (noventa e nove) poços de visita

- 28 (vinte e oito) terminais de limpeza

- 7250 (sete mil e duzentos e cinquenta) metros de tubulação de PVC

Assim, os serviços a serem executados abrangem a conexão das redes de esgoto por meio de um anel hidrossanitário, cujos efluentes serão recalcados por estações elevatórias e transportados ao tronco coletor da CEDAE, num valor total estimado de 2 (dois) milhões de reais. O tronco coletor será localizado na Avenida Brasil. 
As OM foram agrupadas em duas bacias contribuintes, denominando-se Bacia "A" e Bacia "B", contendo os serviços de ligações prediais e rede coletora de esgoto. A "Bacia A" abrange o Centro de Instrução Almirante Alexandrino (CIAA), a Liga de Esporte do Arsenal da Marinha (LESPAM), a Casa dos Marinheiros (CMN) e o Grupamento dos Fuzileiros Navais do Rio de Janeiro. Já a bacia de esgotamento denominada "Bacia B" compreende as seguintes organizações militares: Centro de Educação Física Almirante Adalberto Nunes (CEFAN), Base de Abastecimento da Marinha no Rio de Janeiro (BAMRJ) e Centro de Instrução Almirante Graça Aranha (CIAGA). Veja-se a distribuição conforme a figura 5.5:

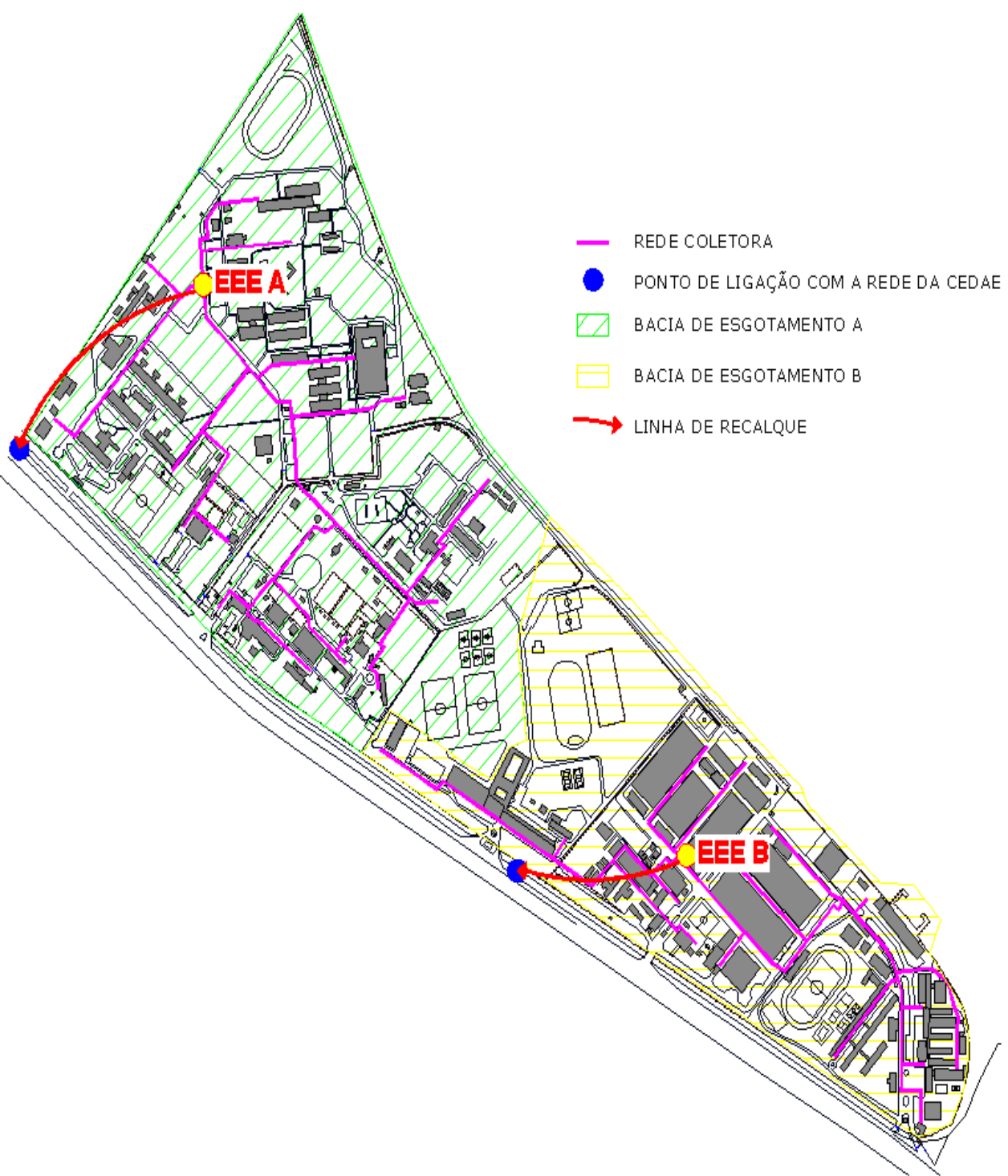

Figura 5.5: Bacias de contribuição do Complexo Naval da Av. Brasil. Fonte: a autora. 
Como os órgãos pertencentes à Marinha do Brasil necessitam licitar os seus contratos, como regra, por meio do Pregão $n^{\circ} 7 / 2010$, surgiu o Contrato ${ }^{\circ}$ 62600/2010-016/00, que ficou responsável pelo Projeto Básico e Executivo de Adequação do Sistema de Esgotamento Sanitário para o Complexo Naval da Avenida Brasil, na cidade do Rio de Janeiro - RJ.

O projeto observou a inexistência do sistema separador absoluto dos sistemas de esgotamento sanitário do sistema de drenagem pluvial, situação recorrente na maior parte das Organizações Militares do complexo, assim como da utilização de materiais obsoletos (manilha e ferro) e diâmetros inadequados à população existente. Desta forma, o projeto visou a elaboração de um sistema de esgotamento sanitário adequado ao tipo separador absoluto, com todas as devidas ligações prediais, captação e transporte, incluindo estações elevatórias para permitir o correto escoamento para a rede pública.

Desta forma, em 5 de dezembro de 2011 foi celebrado um contrato, cujo objeto é a execução das obras de modernização do sistema de redes de esgoto sanitário do Complexo de Organizações Militares da Marinha do Brasil na Avenida Brasil. Por diversas razões técnicas, destacando-se a necessidade de alteração do modo de execução da técnica de lançamento das tubulações, em decorrência de interferências de tubulações pré-existentes, nível de água no terreno e diversas outros óbices, foi necessário efetuar a alteração do projeto e de itens de execução, tendo dado causa à consequente modificação do término do prazo de execução do contrato.

As obras requerem adequação de cronogramas com as tarefas das $\mathrm{OM}$, pois em muitos casos há necessidade de destruição de pavimentações que dificultam o acesso nas $\mathrm{OM}$ e afetam diretamente o seu funcionamento, com exemplificado na figura 5.6. Isso também é muito importante para o êxito da conclusão das obras. 


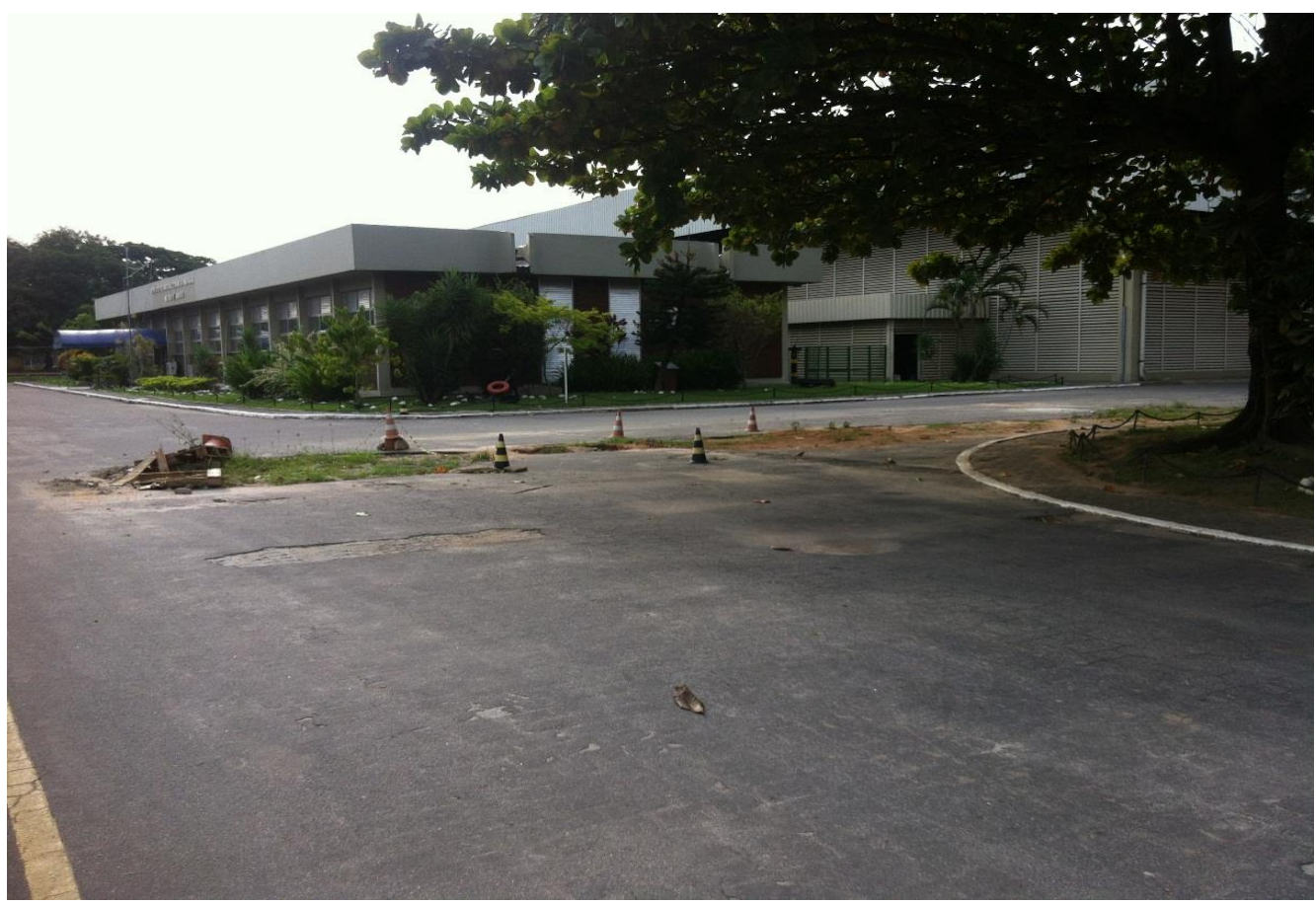

Figura 5.6: Arruamento com obras no Complexo Naval da Av. Brasil. Fonte: a autora.

Também neste caso, para que ocorra o completo êxito da tarefa, será necessária uma cooperação da CEDAE. Assim, além da rede coletora e das duas estações elevatórias, o sistema será compreendido com a implantação de duas linhas de recalque, figura 5.7, que direcionarão o esgoto coletado no Complexo Naval ao coletor tronco que será construído pela CEDAE, que será alocado paralelamente à Avenida Brasil. Em cada uma das linhas de recalque foi necessário projetar uma travessia para transpor o córrego que passa paralelo ao Complexo Naval.

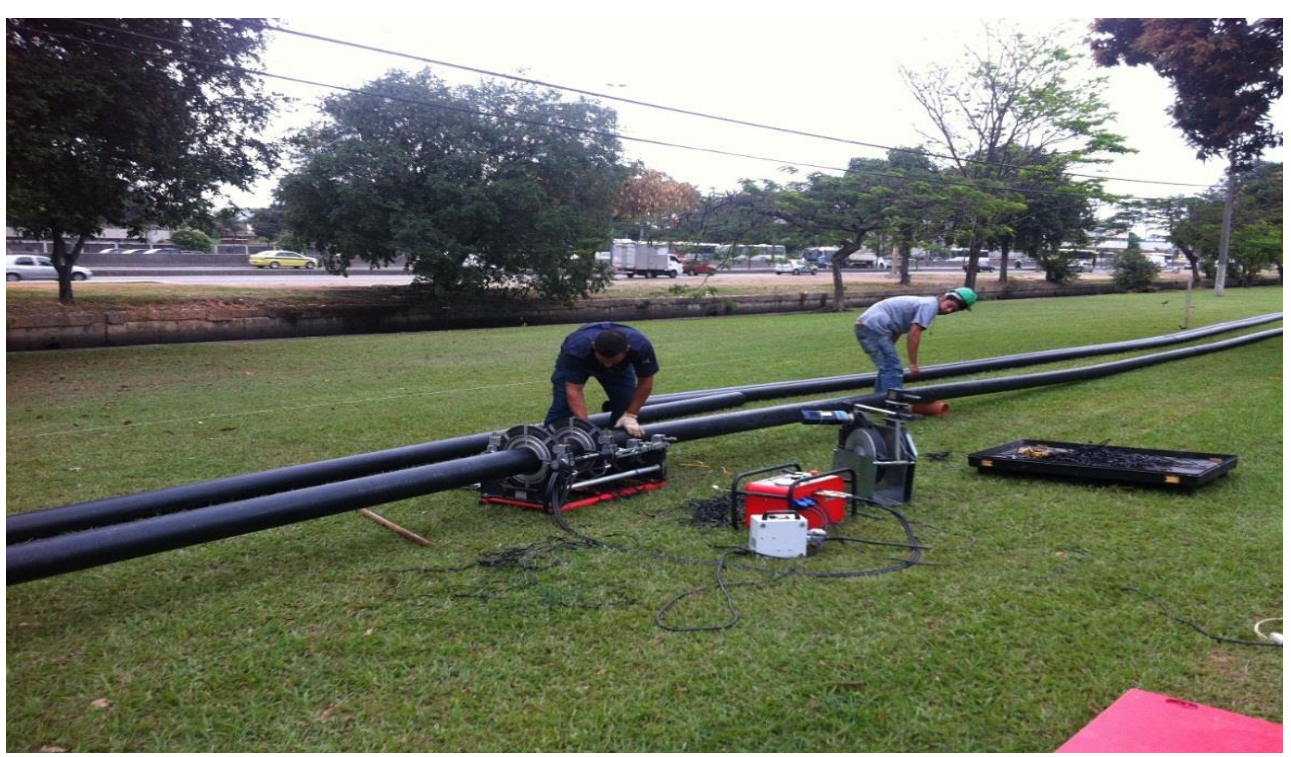

Figura 5.7: Lançamento de tubulações no Complexo Naval da Av. Brasil. 
Durante a execução dos serviços, muitas foram as interferências encontradas. Quase todas sempre implicam em alteração no projeto inicial, com fatos novos supervenientes à celebração do contrato de execução da obra. No caso do anel hidrossanitário no Complexo Naval da Avenida Brasil, destacam-se:

- necessidade de alteração do modo de execução da técnica de lançamento das tubulações;

- interferências entre redes, tal como a existente quando da execução dos serviços de escavação do coletor 11, tendo sido encontrada uma laje nas dimensões $31 \mathrm{~m}$ com $15 \mathrm{~cm}$ de espessura, o que paralisou a escavação para sua remoção;

- refazimento de serviços, como o afundamento do solo, em decorrência da má qualidade de execução do aterramento com compactação do solo.

Como visto no capítulo 1, a gestão eficiente com um levantamento efetivamente complexo é um modo de eliminar estas interferências supervenientes. Entretanto, no caso de construções antigas não catalogadas, não é possível eliminar este entrave, mas certo é que catalogar a partir de agora eliminará a chance de ocorrência do mesmo problema no futuro.

Em decorrência da interferência de laje de grande porte antiga e desconhecida em sua origem, encravada no encaminhamento das tubulações, foi adotada como solução a perfuração direcional, indicada na figura 5.8, nova técnica que minimizou o impacto dos custos, otimizou o tempo de execução e solucionou o problema de manter o encaminhamento das tubulações.

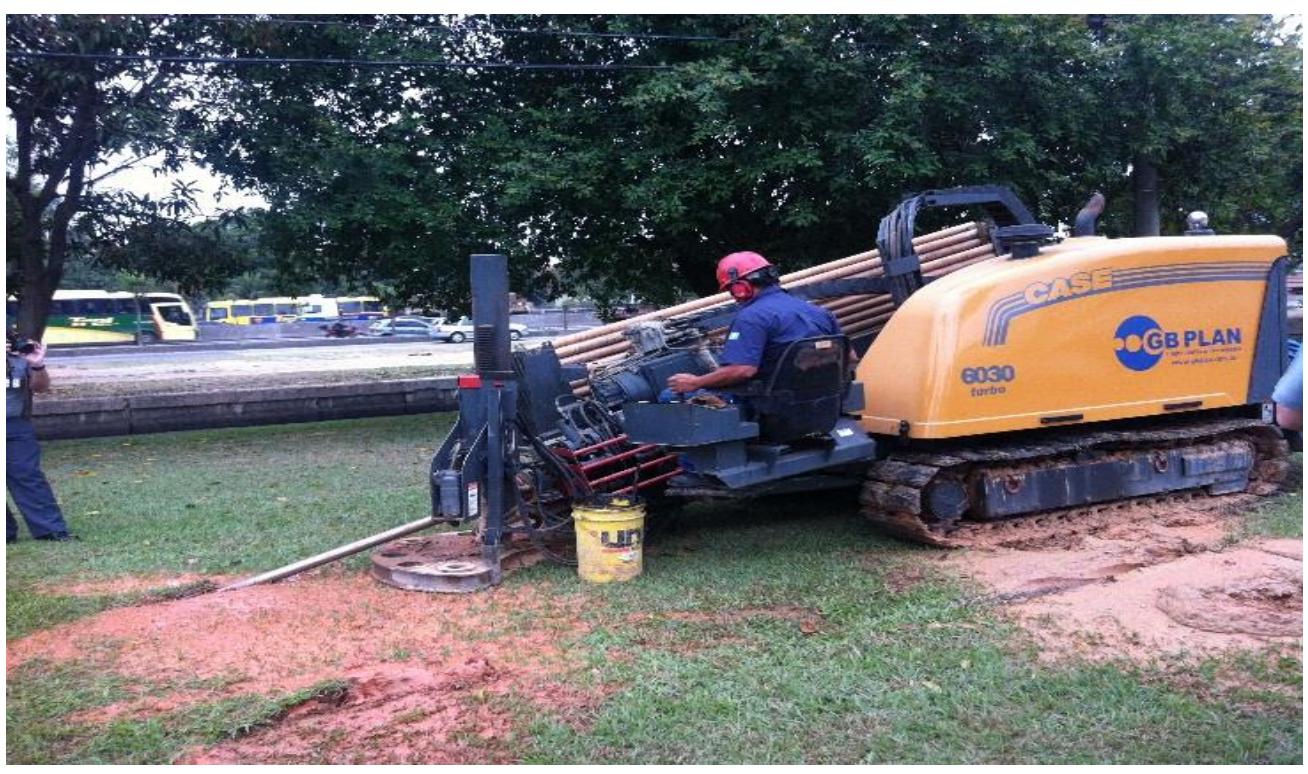

Figura 5.8: Técnica nova de lançamento das tubulações. Fonte: a autora. 


\section{3 .3}

\section{Complexo Naval da Ilha do Governador}

O Complexo Naval da Ilha do Governador (CNIG) situa-se à Estrada do Quilombo, S/N - Bananal - Ilha do Governador - RJ. Como visto neste capítulo, a Ilha do Governador é um dos contribuintes para a Bacia da Guanabara e a melhoria de seu sistema representa a melhoria do meio ambiente na cidade do Rio de Janeiro.

Para esta área, a Marinha do Brasil contratou um Projeto Executivo de Engenharia para a modernização dos Sistemas de Redes de Esgoto Sanitário e de Águas Pluviais, tendo em vista que este sistema ainda não contempla o sistema separador absoluto, bem como possui um conjunto de fossas sépticas, filtros anaeróbios e estações de tratamento de esgoto, muitas com baixo desempenho ou desativadas, sendo que o sistema ainda não encaminha os efluentes para uma rede de esgoto pública.

O Complexo Naval da Ilha do Governador (CNIG), figura 5.9, abrange as seguintes Organizações Militares (OM):
a) Comando da Divisão Anfíbia (COMDIVANF);
b) Base de Fuzileiros Navais da Ilha do Governador (BFNIG);
c) Batalhão de Blindados de Fuzileiros Navais (BTLBLDFUZNAV);
d) $1^{\circ}$ Batalhão de Infantaria de Fuzileiros Navais da Ilha do Governador $\left(1^{\circ}\right.$ BTLINFFUZNAV $)-($ Riachuelo $)$;
e) $2^{\circ}$ Batalhão de Infantaria de Fuzileiros Navais da Ilha do Governador ( $2^{\circ}$ BTLINFFUZNAV) - (Humaitá);
f) $3^{\circ}$ Batalhão de Infantaria de Fuzileiros Navais da Ilha do Governador $\left(3^{\circ}\right.$ BTLINFFUZNAV) - (Paissandu);
g) Batalhão de Controle Aerotático e Defesa Antiaérea (BTLCTAETATDAAE);
h) Batalhão de Artilharia de Fuzileiros Navais (BTLARTFUZNAV);
i) Centro de Instrução Almirante Sylvio de Camargo (CIASC); e
j) Batalhão de Comando e Controle (BTLCMDOCT). 


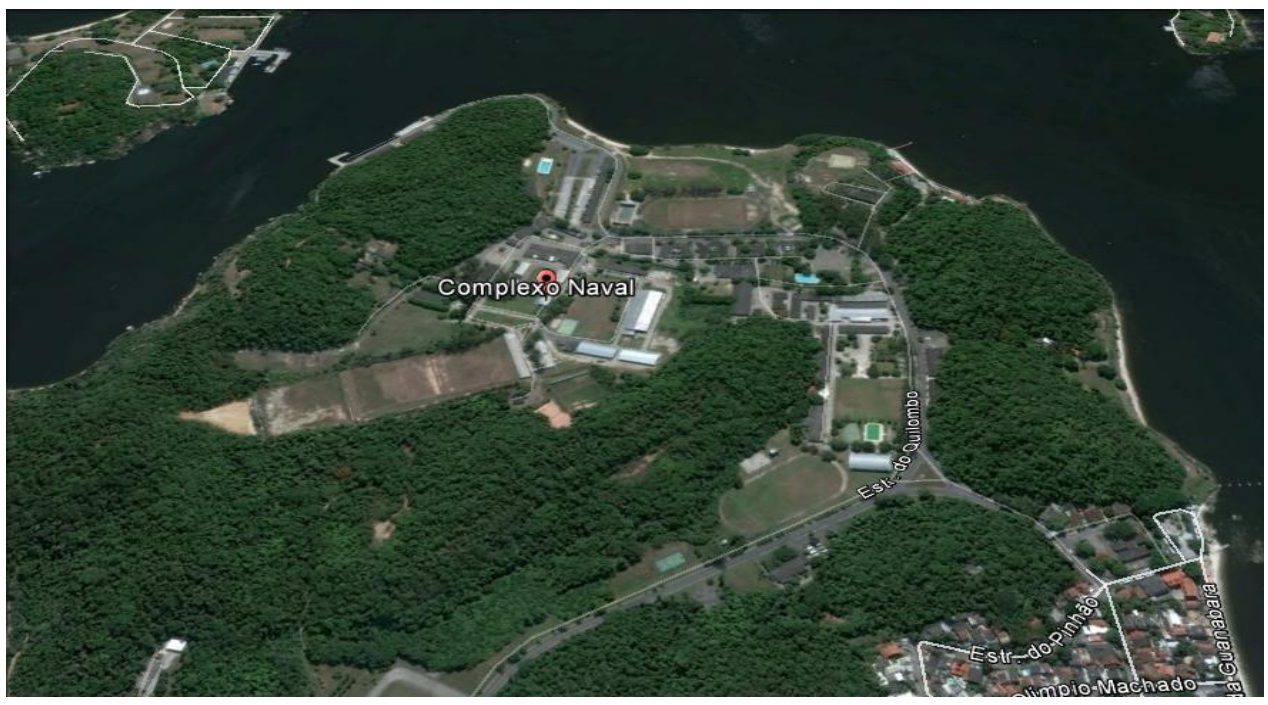

Figura 5.9: Complexo Naval da Ilha do Governador. Fonte: Google Earth. Acesso em 10 set 2015.

O levantamento da situação existente constatou as seguintes necessidades:

a) segregar as redes de esgoto sanitário e águas pluviais;

b) instalar novas redes de esgoto sanitário e de águas pluviais;

c) construção de elevatórias;

d) remover todo o esgoto sanitário e direcioná-lo para a rede da concessionária CEDAE.

e) drenar as águas pluviais e direcioná-las para a Baía de Guanabara; e

f) tratar o esgoto do tipo industrial gerado antes de lançar na rede de esgoto sanitário;

g) construir caixas separadoras de óleo;

h) desobstruir as caixas íntegras que serão mantidas;

i) construir caixas retentoras de sólidos antes das caixas de gordura;

A fim de eliminar qualquer possibilidade de erros de projeto, foi apresentado para a licitação um escopo de serviços prévios a fim de apoiar o projetista. Assim, foi informado que, previamente à execução do projeto deve ser executado um levantamento plani-altimétrico e um cadastramento de rede. $\mathrm{O}$ levantamento plani-altimétrico é de suma importância para o estudo do escoamento dos efluentes e da necessidade de Estações Elevatórias para que o sistema atenda ao escoamento livre do esgoto. Já, o cadastramento deve indicar as cotas da tampa e fundo, entradas e saídas, estado de conservação, diâmetro dos 
tubos, dimensionamento, identificação e direção do efluente. Este cadastramento servirá não somente como base de dados para a elaboração do projeto final como também servirá de arquivo histórico para futuras reformas ou novas construções, cujo conhecimento prévio elimina a possibilidade de interferências durante a execução da obra.

Também devem ser efetuados testes de escoamento, com o fim de verificar a existência de obstruções e o sentido dos efluentes, podendo-se utilizar o teste de anilina quando for de difícil interpretação o encaminhamento dos efluentes no sistema existente. E neste caso, alguns dispositivos podem estar em pleno funcionamento e podem ser aproveitados.

Após o levantamento do estado existente do sistema de esgoto a empresa contratada deve apresentar um estudo preliminar e, em seguida o projeto executivo, que será objeto de nova licitação, desta vez para a execução das obras.

Neste ano de 2015, a empresa contratada Torre Arquitetos Associados, vencedora da licitação responsável pela execução do levantamento e do projeto executivo, ainda se encontra elaborando e definindo os detalhes deste projeto e concluindo o correto cadastramento de todo o Complexo. O projeto executivo está sendo apresentado à DOCM a fim de que seja analisada a adequação do projeto, seja quanto ao uso correto de técnica de engenharia, seja quanto à adequação às normas técnicas, para que, enfim, seja aprovado por aquela Diretoria Técnica de forma a subsidiar a futura licitação para as obras de modernização do Complexo Naval da Ilha do Governador.

O caminho é longo, mas com recursos e seriedade de propósito, tanto da contratante como da contratada, o sistema de esgoto dos Complexos serão, um a um, modernizados e o meio ambiente agradecerá, assim como as gerações futuras.

\section{4}

\section{Análise dos Estudos de Caso e uma Visão de Futuro}

\section{4 .1}

\section{Considerações Relevantes}

$\mathrm{Na}$ maioria dos quartéis da Marinha do Brasil existem como opção de sistema de descarte dos efluentes de esgoto sanitário o sistema fossa-filtro 
anaeróbio. Este sistema reduz a carga orgânica lançada nos corpos receptores, e atendem a maioria das demandas, inclusive às obrigações normativas. Entretanto, com a chegada dos troncos coletores é dever da Marinha do Brasil utilizar esta rede, ou seja, adequar-se e redefinir o seu projeto de coleta, transporte e descarte.

Para que isto se tornasse realidade, foi necessário elaborar um projeto de engenharia de saneamento, um processo licitatório e a contratação de uma empresa construtora. São muitas etapas que a Administração Pública não pode deixar de observar. E algumas críticas podem ser efetuadas em face dos estudos de caso, a fim de que, em situações futuras, seja possível melhorar o resultado das ações empreendidas.

A primeira observação relaciona-se com a elaboração dos projetos básicos, necessários para a composição do processo licitatório para a contratação de uma empresa de construção. Como no caso do Complexo Naval da Ilha do Governador, o próprio projeto depende de licitação de uma empresa com capacidade de elaborar o projeto de saneamento. E o projeto incluiu desde o levantamento das condições dos equipamentos e dispositivos do sistema de esgoto, até o cálculo e decisão final sobre o lançamento da nova rede captação e destinação de esgoto do Complexo.

A necessidade de antever, por meio de uma sondagem, o tipo de solo onde será apoiada a tubulação, dispositivos e equipamentos é imprescindível para o bom êxito do projeto. E isto deve ser considerado quando da elaboração dos requisitos a comporem a licitação do projeto. $\mathrm{O}$ caso da laje de grande porte enterrada no Complexo Naval da Avenida Brasil reflete a necessidade deste estudo preliminar, porquanto a paralisação da obra, a necessidade de estudos para verificar uma nova trajetória para a tubulação, e os custos extraordinários que enfrentam a limitação de $25 \%$ (vinte e cinco por cento) do valor contratado na licitação são situações indesejadas, que afetam diretamente a Administração e o próprio sistema de esgoto já que este irá demorar mais a ser concluído, maior tempo de poluição dos corpos receptores.

Além disso, deve ser observado que o projeto não se limita à elaboração de um sistema de esgoto, mas abrange também um sistema de drenagem, que, em regra, se encontra ainda misturado com o sistema de esgoto e necessita ser segregado um do outro. $O$ processo também deve incluir a necessidade do levantamento topográfico da área, para que se possa efetivar um projeto adequado, 
considerando a necessidade de construção ou reforma de estações elevatórias (EE) para o novo sistema de esgoto e drenagem.

Segundo o Arquiteto Pellegrino, a construção de caixas retentoras de sólidos (CRS) antes das caixas de gordura (CG) também é uma questão importante para adequar a rede à realidade dos seus usuários, que lançam detritos de grande porte diretamente pelo ralo, sendo que esta caixa permite que haja um recolhimento prévio antes do gradeamento, evitando que atinja o sistema da caixa de gordura.

Os projetos de engenharia são de grande importância para o êxito da modernização do sistema de esgoto da Marinha do Brasil. Entretanto, a necessidade de integrar o sistema à rede pública depende também da disponibilidade da concessionária, realidade essa que não se coaduna com a realidade do Brasil. Cabe aos dois setores executivos de instâncias diferentes coordenarem a disponibilização financeira, os prazos para a consecução das obras e, por fim, a colaboração com dados específicos da expansão do sistema e necessidade apresentada, pois, desta forma, elimina-se o desperdício financeiro e o desencontro das agendas de interesses.

\section{4 .2}

\section{Visão de Futuro}

A despeito das ações que já estão sendo implementadas com recursos advindos da conjuntura política de jogos mundiais, a modernização do sistema de esgoto na Marinha do Brasil ainda é incompleta, pois apenas parte do sistema foi contemplado com os recursos do Governo Federal por meio do Programa de Aceleração da Construção Civil (PAC). Trata-se apenas de uma adequação ao que já deveria estar efetivamente implementado, ao se comparar com os países de melhor poder econômico. Já não é mais tempo de se discutir as possibilidades de elaborar um sistema de separação absoluta, mas, sim, de como reduzir ou eliminar a produção do lixo e como efetuar o descarte correto deste. E o efluente do esgoto também é um grande gerador de lixo, mas este lixo não é visto diretamente, pois é lançado nos corpos receptores por tubulações que, via de regra, sequer são observadas visualmente pelas pessoas. 
A maioria dos efluentes de esgoto doméstico advém do consumo da água. Então, se seu volume está diretamente ligado a este consumo, pode-se pensar no reaproveitamento destes líquidos, ainda que seja apenas para um consumo indireto, ou seja, para a rega das plantas ou lavagem de carros e pisos.

Nos futuros empreendimentos militares é importante analisar a possibilidade de, apesar de mais caro, introduzir um sistema de reuso dos efluentes captados, pois isto se coaduna com a redução do consumo de água e traz benefícios até mesmo de autonomia, pois a geração de água, ainda que seja somente para a rega de plantas ou lavagem de pisos e automóveis, reduz a necessidade de consumo dependente, o que é uma vantagem até mesmo estratégica para Organizações Militares, se pensarmos em tempos de guerra.

$\mathrm{Na}$ Marinha do Brasil se encontra em pleno processo de implantação uma Estação de Tratamento de Esgoto (ETE), com capacidade de atendimento integral às demandas existentes para a lavagem de carros e de pisos, com alto grau de qualidade da água em Itaguaí, nos Estaleiros de Submarinos ali em construção. Este ETE somente foi possível tendo em vista o tipo de construção a que se destina, ou seja, faz parte de um programa militar de alto grau de sigilo e importância estratégica ímpar para o país, cuja verba ainda está garantida. Trata-se do Programa de Construção de Submarinos (PROSUB), cuja Base Naval e Estaleiros de Construção e Manutenção se encontram ainda em execução. Neste caso, há recursos disponíveis para um projeto arrojado e moderno, bem como para que se proceda de forma estratégica, como é o caso de obtenção parcial de autonomia de consumo de água. Por óbvio, para a produção do efluente há que se consumir água, mas o seu reuso e armazenamento já é um grande ponto estratégico, além de uma forma de reduzir os gastos futuros, com o que o custo da ETE se espraia ao longo dos anos em que se tornará, também, armazenadora de água para consumo.

Esta situação é desejável para todos os Complexos, exceto para aqueles que não justifiquem o equilíbrio entre a demanda e a produção de água para reuso. Mas nestes, é importante que sejam feitas manutenções permanentes nas fossas e nos filtros anaeróbios de fluxo ascendente, de forma a manter a qualidade de seu desempenho, com baixa carga orgânica a ser lançada nos corpos receptores ou, se possível, é desejável que sejam substituídos por Estações de Tratamento Compactas que tem uma eficiência maior que a deste conjunto. 
É importante analisar que nem sempre os recursos são capazes de integrar uma obra complexa e de grandes proporções, como as que foram apresentadas nos estudos de caso. Entretanto, há a necessidade de elaboração de um projeto de saneamento que abranja integralmente toda a área militar, pois o projeto para ser adequado deve ser faseado desde a sua concepção, a fim de evitar que para cada reforma parcial haja interferências entre redes existentes, recalques não previstos, descoberta superveniente de Estações Elevatórias ou Estações de Tratamento de Esgotos em bom estado mas paralisadas e, até mesmo, erros de encaminhamento de tubulações em decorrência da topografia do solo.

Ainda que executado de forma parcial, o fato é que o projeto de modernização deve ser realizado de forma integral, contendo dispositivos modernos como as ETE, comuns ou compactas, UASB, Reatores, dentre outros equipamentos de tratamento mais eficientes, e com isso melhorar o desempenho do sistema de esgoto dentro de um planejamento espraiado no tempo. E enquanto não haja a disponibilidade efetiva de recursos, pode-se preparar um projeto sem emergência com técnicas modernas, o que permite um bom estudo da melhor metodologia a ser aplicada e uma modernização pautada em um planejamento.

A educação ambiental também é uma forma importante de propagar o baixo consumo de água e, com isso, a baixa produção de efluentes de esgoto, além da forma regular de destinação dos resíduos, a fim de garantir a saúde dos corpos hídricos. Desta forma, não somente a preocupação com o material, mas também com o pessoal, é uma ação que traz benefícios para o uso do sistema de esgoto da Marinha do Brasil. 


\section{6}

\section{CONCLUSÃO}

Muitos são os desafios a serem enfrentados pela Marinha do Brasil, com o fim de melhorar o desempenho do sistema de esgoto em suas edificações, o que abrange a projeção de um sistema moderno, a gerência adequada dos recursos, o controle administrativo dos objetos licitados e seus processos, a fiscalização dos contratos de execução, tanto dos projetos quanto das obras, a acurada análise da dispensa ou não do licenciamento ambiental de Estações de Tratamento de Esgotos pelos órgãos ambientais, bem como a aplicabilidade das diversas técnicas de reuso que podem ser implementadas.

No que tange à gestão dos recursos, sugere-se um procedimento anual, por meio da análise das obras e projetos mais necessários e prementes de conclusão, que é uma forma de garantir a manutenção e modernidade do sistema de esgoto. Mas como esta análise tem como subsídio os dados levantados dos Planos Diretores, que representam as necessidades do sistema de forma atual, é necessário que estes planos sejam realmente atualizados por todas as Organizações Militares, pois sem isso haverá deficiência no momento da decisão da destinação dos recursos.

Além disso, estar em dia com as demandas é uma forma importante de se dispor corretamente dos recursos, tendo em vista que as sucessivas reduções orçamentárias no orçamento da Marinha do Brasil importa em bem atender as maiores e importantes demandas, sem erro para não ocorrer desperdício. A redução deste ano foi estimada no início do ano na ordem de $40 \%$ da verba do ano antecedente, o que poderá se operar novamente em forma de novo corte orçamentário, em patamares ainda desconhecidos. Portanto, conhecer bem para prever a fim de prover, frase de Augusto Comte, ainda é uma importante forma de gerir os recursos.

Em consonância com a ação acima, minimizar as interferências que podem ocorrer ao longo dos projetos e obras, além de buscar a modernização do sistema de esgoto por meio da instalação de Estações de Tratamento Compactas, além é claro da implementação de procedimentos de limpeza de fossas do sistema ligado 
aos filtros anaeróbios de fluxo ascendente (FAFA), manutenção de Estações Elevatórias e Estações de Tratamento de Esgoto existentes, e a inclusão de um estudo de reuso dos efluentes também é aproveitar ao máximo os recursos financeiros.

Além disso, é necessário compatibilizar os projetos executados por profissionais distintos, avaliar o sistema ou metodologia construtiva adotado, definir de forma clara e detalhada o objeto a ser licitado, acompanhar a execução dos projetos básicos contratados com um profissional da área de engenharia, avaliar se haverá impacto dos custos de licenciamento e de contrapartidas ambientais; enfim, atuar desde a concepção e definição da destinação dos recursos até a operacionalização destes é a garantia de uma gestão eficiente e que promoverá uma melhor adequação entre a concepção e a execução de todo o sistema de esgoto da Marinha do Brasil.

É importante observar que a utilização otimizada dos licenciamentos ambientais é a garantia de atuar com responsabilidade na defesa do meio ambiente. E atuar de forma otimizada é utilizar os processos de dispensa dos licenciamentos ambientais pelos órgãos ambientais, nos casos especiais de empreendimentos militares, com emprego de preparo e força. Entretanto, deve-se proceder com a cautela necessária para que haja o levantamento das atividades da Organização Militar e identificação da atividade prioritária, para que se verifique, segundo a tabela sugerida no Capítulo 3, quando é de fato caso de dispensa. E sendo caso de dispensa, há de se atuar de forma a arquivar todos os atos de levantamento de dados, documentando tudo em relatórios fotográficos ou vídeos, efetuando-se auditorias ambientais internas e levantando o histórico da biodiversidade local, dentre outros, para que se possa, inclusive, proceder avaliações prospectivas e minimização de possíveis impactos.

No que tange à análise da situação de coleta e descarte do sistema de esgoto da Marinha do Brasil, é possível concluir que o sistema atual de fossa séptica-filtro anaeróbio de fluxo ascendente (FAFA) tem boa eficiência mas não retrata um sistema moderno. Desta forma sugere-se que seja mantido até que sejam disponibilizadas as redes púbicas para a captação dos efluentes dos Complexos Navais distribuídos por todo o Brasil ou substituídos o quanto antes por Estações de Tratamento Compactas que aumentam a sua eficiência e tem boa relação de custo-benefício. 
No sistema fossa-filtro anaeróbio de fluxo ascendente (FAFA) existente deve ser efetuada a limpeza periódica de forma regular e tomadas as providencias prévias como a provisão dos recursos para a manutenção do sistema ao longo do ano, além de ser necessário que se levante se o sistema se encontra separado de forma absoluta do sistema de drenagem, situação esta recorrente nas Organizações Militares.

Em relação às cotas baixas dos terrenos, que usualmente ocorrem nos terrenos da Marinha, por se situarem nas proximidades dos rios e mares, a construção de comportas e gradeamentos é uma solução para impedir o refluxo tanto das águas quanto a obstrução por lixo na tubulação de saída do sistema. Outrossim, para as caixas de gordura que recebem, de forma irregular, materiais de grandes dimensões que afetam o seu correto funcionamento, sugere-se a construção de caixa retentora de resíduos sólidos, a fim de eliminar o problema e melhorar o desempenho do sistema, como demonstrado ter sido eficiente nos casos concretos.

Por fim, verifica-se que a Marinha do Brasil encontra-se executando obras que se destinam e se relacionam com o Programa de Despoluição da Baía de Guanabara, cujos recursos advém justamente para este Programa. Portanto, neste momento, está em plena execução da modernização de todo o seu sistema sanitário nos principais Complexos Navais localizados na cidade do Rio de Janeiro, adequando o sistema para o sistema separador absoluto, construindo estações elevatórias e tubulações de encaminhamento de todo o esgoto para a nova rede pública de coleta de esgoto, que também se encontra em fase de construção sob a responsabilidade da concessionária responsável pela coleta de esgoto público no Município do Rio de Janeiro (CEDAE).

Diante do quadro apresentado, pode-se afirmar que a Marinha do Brasil, embora ainda esteja aquém do sistema ideal, porquanto necessita de uma programação de obras de modernização em consonância com os recursos financeiros, tem executado diversas ações e desenvolvido técnicas de engenharia no sentido de otimizar a gestão dos seus recursos e aplicá-los na manutenção e modernização de seu sistema, o que importa concluir que todas as ações são destinadas à melhoria de seu desempenho e que se revestem do caráter protetivo constitucional de preservação do meio ambiente. 


\section{REFERÊNCIAS BIBLIOGRÁFICAS}

ASSOCIAÇÃO BRASILEIRA DE NORMAS TÉCNICAS. NBR 8160: Sistemas de Esgotos Sanitários. Rio de Janeiro, 2009. 74 p.

ASSOCIAÇÃO BRASILEIRA DE NORMAS TÉCNICAS. NBR ISO 14001: Sistemas de Gestão Ambiental. Rio de Janeiro, 2004. 33 p.

ASSOCIAÇÃO BRASILEIRA DE NORMAS TÉCNICAS. NBR 7229: Projeto, construção e operação de sistemas de tanques sépticos. Rio de Janeiro, 1993. $15 \mathrm{p}$.

ASSOCIAÇÃO BRASILEIRA DE NORMAS TÉCNICAS. NBR 13969: Tanques Sépticos: Unidades de Tratamento Complementar e disposição final dos efluentes líquidos Projeto, construção e operação. Rio de Janeiro, 1997. $60 \mathrm{p}$.

Agência Nacional de Águas (ANA). Disponível em: http://conjuntura.ana.gov.br/conjuntura/srh_su_s.htm, Acesso em 13NOV2014.

BAUMAN, Zygmunt. Modernidade Líquida. Rio de Janeiro: Jorge Zahar Editor, 2000. 255 p.

BRASIL. Constituição da República Federativa do Brasil, de 5 de outubro de 1988. Diário Oficial da República Federativa do Brasil, Brasília, DF, 5 out. 1988. Disponível.em:.http://www.senado.gov.br/atividade/const/con1988/CON1988_15. 09.2015/ind.asp . Acesso em: 17 nov 2015

BRASIL. Lei n. ${ }^{\circ}$ 8.666, de 21 de junho de 1993. Regulamenta o art. 37, inciso XXI, da Constituição Federal, institui normas para licitações e contratos da Administração Pública e dá outras providências. Diário Oficial da República Federativa do Brasil, Brasília, DF, 21 jun. 1993. Disponível em: < http://www.planalto.gov.br/ccivil_03/Leis/L8666cons.htm>. Acesso em: 10 mai. 2015.

BRASIL. Lei nº 6.938, de 31 de agosto de 1981. Dispõe sobre a Política Nacional do Meio Ambiente, seus fins e mecanismos de formulação e aplicação, e dá outras providências. Diário Oficial da República Federativa do Brasil, Brasília, DF, 31 ago.1981.Disponível.em:.<.http://www.planalto.gov.br/ccivil_03/Leis/L6938.htm >. Acesso em: 22 mai. 2015.

BRASIL. Lei n. ${ }^{\circ}$ 9.065, de 20 de junho de 1995. Dá nova redação a dispositivos da Lei $n^{\circ}$ 8.981, de 20 de janeiro de 1995, que altera a legislação tributária federal, e dá outras providências. Diário Oficial da República Federativa do Brasil, Brasília, DF, 20 jun. 1995. Disponível em: < http://www.planalto.gov.br/ccivil_03/LEIS/L9065.htm>. Acesso em: 10 mai. 2015. 
BRASIL. Lei Complementar n. ${ }^{\circ}$ 97, de 9 de junho de 1999. Dispõe sobre as normas gerais para a organização, o preparo e o emprego das Forças Armadas. Diário Oficial da República Federativa do Brasil, Brasília, DF, 9 jun. 1999. Disponível em: < http://www.planalto.gov.br/ccivil_03/leis/LCP/Lcp97.htm>. Acesso em: 10 mai. 2015.

BRASIL. Lei . $^{\circ} 11.445$, de 5 de janeiro de 2007. Estabelece diretrizes nacionais para o saneamento básico; altera as Leis $\mathrm{n}^{\text {os }} 6.766$, de 19 de dezembro de 1979, 8.036, de 11 de maio de 1990, 8.666, de 21 de junho de 1993, 8.987, de 13 de fevereiro de 1995; revoga a Lei n. $^{\circ} 6.528$, de 11 de maio de 1978; e dá outras providências. Diário Oficial da República Federativa do Brasil, Brasília, DF, 5 jan. 2007. Disponível em: < http://www.planalto.gov.br/ccivil_03/_ato20072010/2007/lei/111445.htm>. Acesso em: 10 mai. 2015.

BRASIL. Decreto n. ${ }^{\circ} 8.141$, de 20 de novembro de 2013. Dispõe sobre o Plano Nacional de Saneamento Básico - PNSB, institui o Grupo de Trabalho Interinstitucional de Acompanhamento da Implementação do PNSB e dá outras providências. Diário Oficial da República Federativa do Brasil, Brasília, DF, 20 nov. 2013. Disponível em: < http://www.planalto.gov.br/ccivil_03/_Ato20112014/2013/Decreto/D8141.htm>. Acesso em: 10 mai. 2015.

BRASIL. Lei n. ${ }^{\circ} 4.320$, de 17 de março de 1964. Estatui Normas Gerais de Direito Financeiro para elaboração e controle dos orçamentos e balanços da União, dos Estados, dos Municípios e do Distrito Federal. Diário Oficial da República Federativa do Brasil, Brasília, DF, 17 mar. 1964. Disponível em: < http://www.planalto.gov.br/ccivil_03/Leis/L4320.htm>. Acesso em: 10 mai. 2015.

BRASIL. Lei n. ${ }^{\circ} 13.080$, de 2 de janeiro de 2015. Dispõe sobre as diretrizes para a elaboração e execução da Lei Orçamentária de 2015 e dá outras providências. Diário Oficial da República Federativa do Brasil, Brasília, DF, 2 jan. 2015. Disponível em: <http://www.planalto.gov.br/ccivil_03/_Ato20152018/2015/Lei/L13080.htm>. Acesso em: 10 mai. 2015.

BRASIL. Decreto Estadual n. ${ }^{\circ} 26.058$, de 14 de março de 2000. Define as macrorregiões ambientais do Estado do Rio de Janeiro e dá outras providências. Diário Oficial do Estado do Rio de Janeiro, Rio de Janeiro, RJ, 14 mar. 2000. Disponível em: < http://gov-rj.jusbrasil.com.br/legislacao/230228/decreto-2605800>. Acesso em: 10 mai. 2015.

BRASIL. Decreto Estadual n. ${ }^{\circ} 42.159$, de 2 de dezembro de 2009. Define as macrorregiões ambientais do Estado do Rio de Janeiro e dá outras providências. Diário Oficial do Estado do Rio de Janeiro, Rio de Janeiro, RJ, 3 dez. 2009. Disponível em: < https://www.legisweb.com.br/legislacao/?id=158541>. Acesso em: 10 mai. 2015.

BRASIL. Ministério do Planejamento. Governo Federal. Gespublica. Disponível em: http://www.gespublica.gov.br/Tecnologias/pasta.2010-04-26.0851676103. Acesso em 5 set 2015. 
CAMPOS, J.R. Programa de Pesquisa em Saneamento Ambiental, Tratamento de Esgoto Sanitário por Processo Anaeróbio Disposição Controlada no Solo. São Paulo: PROSAB, edital 3, 1999. 547 p.

Companhia Estadual de Águas e Esgotos (CEDAE). Disponível em: http://www.cedae.com.br/raiz/002020.asp. Acesso em: 5 de junho 2015

CONAMA. Resolução n. ${ }^{\circ}$ 237, de 19 de dezembro de 1997. Estatui Normas de Maio Ambiente. Disponível em: < http://www.mma.gov.br/port/conama/res/res97/res23797.html>. Acesso em: 10 mai. 2015.

DA CRUZ, Nilber Teixeira. Aplicação da auditoria ambiental de conformidade legal às Organizações Militares. Rio de Janeiro: Escola de Comando e Estado Maior do Exército, 2014. 52 p. (Dissertação. Mestrado. Curso de Direção para Engenheiros Militares)

DESCARTES, René. Discurso do Método. São Paulo: Escala, 2009. 87 p.

DE ARAUJO, Roberto. NUVOLARI, Ariovaldo (coord.). ESGOTO SANITÁRIO: coleta, transporte, tratamento e reuso agrícola. 2 ed. São Paulo: FATEC-SP, 2012. 520 p.

DE BRITTO, Evandro Rodrigues. Tecnologias Adequadas ao Tratamento de Esgotos. Rio de Janeiro: ABES, 2004. 157 p.

FERNANDES, Carlos. Esgotos Sanitários. UNIV./UFPB. João Pessoa, 1997. 435 p.

FREITAS, Juarez. Sustentabilidade: Direito ao futuro. Belo Horizonte: Forum, 2011. $340 \mathrm{p}$.

GUSMÃO, Paulo Dourado. Introdução ao Estudo do Direito. São Paulo: Forense, 1991. 512 p.

JORDÃO, E. Pacheco; PESSOA, C. Arruda. Tratamentos de Esgotos Domésticos. Rio de Janeiro: ABES, 2011. 969 p.

JUNIOR, Almir Mariano de Souza. Compatibilização de projeto arquitetônico, estrutural e sanitário: Uma abordagem teórica e estudo de caso. Revista Monografias Ambientais - REMOA e-ISSN 22361308 - V. 14, N. 2 (2014): Março. $10 \mathrm{p}$.

MACINTYRE, A. Joseph. Instalações Hidráulicas Prediais e Industriais. 4 ed. Rio de Janeiro: LTC, 2010. 596 p.

MARINHA, Serviço de Documentação da. Introdução à história marítima brasileira. Rio de Janeiro: Marinha do Brasil, 2006. 185 p.

MARINHA DO BRASIL. Diretoria-Geral do Material da Marinha. DGMM-0600 - Normas de procedimento técnico-administrativo para o processo de obtenção de instalações terrestres através de execução de obras civis. 
MARINHA DO BRASIL. Disponível em: http://www.marinha.mil.br. Acesso em 15 out 2015.

MINISTÉRIO DAS CIDADES. Programa de Modernização do Setor Saneamento. Disponível em: http://www.pmss.gov.br/. Acesso em 30 set 2015.

MINISTÉRIO DAS CIDADES. Plano Nacional de Saneamento Básico. Disponível.em:http://www.cidades.gov.br/images/stories/ArquivosSNSA/Arquivo s_PDF/plansab_06-12-2013.pdf. Acesso em 25 set 2015.

MORAES, Antonio Carlos Robert. Meio Ambiente e Ciências Humanas. São Paulo: ANNABLUME, 2005. 161 p.

NETTO, Azevedo e outros. Manual de Hidráulica. São Paulo: Edgard Blucher Ltda, 1998. $865 \mathrm{p}$.

OLIVEIRA, Marcos Inoi de. O orçamento como instrumento de planejamento, execução e controle: estudo do caso do Plano Diretor da Marinha do Brasil. Dissertação apresentada à Escola Brasileira de Administração Pública para a obtenção do grau de mestre em Administração Pública. Rio de Janeiro, 2000. 238 p.

SETTI, Arnaldo et. al. Introdução ao Gerenciamento de Recursos Hídricos. 2 ed. Brasília: ANA/ANEEL, 2001. 207 p.

Secretaria de Meio Ambiente e Desenvolvimento Sustentável. Projeto PLANÁGUA SEMADS/GTZ. Bacias Hidrográficas e Rios fluminenses - Síntese informativa por macroregião ambiental. 2001. p. 12

SISTEMA NACIONAL DE INFORMAÇÕES SOBRE SANEAMENTO (SNIS). Disponível em: http://www.snis.gov.br/. Acesso em 10JAN2015.

SOBRINHO, Além Pedro; TSUTYA, M. Tomoyuki. Coleta e Transporte de Esgoto Sanitário. 2. Ed. São Paulo: Departamento de Engenharia Hidráulica e Sanitária da Escola Politécnica da Universidade de São Paulo, 2000. 750 p.

Urban Development Authority (URA). Designing our city: Planning for a sustainable Singapore. Disponível em: https://www.ura.gov.sg/uol/publications/research.resources/books.videos/2012.07 _designing_our_city.aspx. Acesso em 10 set 2015. 